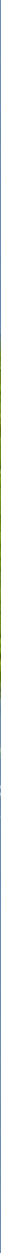

\title{
Valuation of livestock eco-agri-food systems: poultry, beef and dairy
}

W. Baltussen, T. Achterbosch, E. Arets, A. de Blaeij, N. Erlenborn, V. Fobelets, P. Galgani, A. De Groot Ruiz, R. Hardwicke, S.J. Hiemstra, P. van Horne, O. A. Karachalios, G. Kruseman, R. Lord, W. Ouweltjes, M. Tarin Robles, T. Vellinga, L. Verkooijen 
Baltussen, W., T. Achterbosch, E. Arets, A. de Blaeij, N. Erlenborn, V. Fobelets, P. Galgani, A. De Groot Ruiz, R. Hardwicke, S.J. Hiemstra, P. van Horne, O. A. Karachalios, G. Kruseman, R. Lord, W. Ouweltjes, M. Tarin Robles, T. Vellinga, L. Verkooijen; Valuation of livestock eco-agri-food systems: poultry, beef and dairy. Wageningen, Wageningen University \& Research, Trucost \& True Price, publication 2017-039.

TEEB asked for the assessment of the impact of global livestock production systems on human systems and ecosystems. Poultry, beef and dairy production system have been analysed. The analysis shows that in many cases the negative externalities of livestock production are higher than the consumer price paid for the products.

TEEB heeft gevraagd naar een analyse van het effect van veehouderijsystemen in verschillende delen van de wereld op de maatschappij en ecologische systemen. Voor pluimvee, rundveehouderij en melkveehouderij zijn analyses uitgevoerd. De analyse laat zien dat de maatschappelijke kosten vaak hoger zijn dan de consumentenprijs van de veehouderijproducten.

Key words: Livestock, poultry, beef, dairy, true price

This report can be downloaded for free at http://dx.doi.org/10.18174/420536 or at www.wur.eu/economic-research (under Wageningen Economic Research publications).

(C) 2017 Wageningen Economic Research

P.O. Box 29703, 2502 LS The Hague, The Netherlands, T +31 (0)70 3358330

E communications.ssg@wur.n, http://www.wur.eu/economic-research

Wageningen Economic Research is part of Wageningen University \& Research.

\section{(cc) BY-NC}

For its reports, Wageningen Economic Research utilizes a Creative Commons Attributions 3.0 Netherlands license.

\section{(C) 2017 Wageningen Economic Research}

The user may reproduce, distribute and share this work and make derivative works from it. Material by third parties which is used in the work and which are subject to intellectual property rights may not be used without prior permission from the relevant third party. The user must attribute the work by stating the name indicated by the author or licensor but may not do this in such a way as to create the impression that the author/licensor endorses the use of the work or the work of the user. The user may not use the work for commercial purposes.

Wageningen University \& Research (legal entity: Stichting Wageningen Research) is not liable for any loss or damages suffered as a result of the use of this report. Wageningen University \& Research (legal entity: Stichting Wageningen Research) accepts no liability for printing and/or typographical errors. This study was subsidized by TEEB and was carried out by a consortium under the management of Wageningen University \& Research. Trucost performed the monetization of the top-down approach and True Price performed the monetization of the bottom-up approach. The information and views set out in this study are those of the authors and do not necessarily reflect the official opinion of TEEB.

Wageningen Economic Reseach is ISO 9001:2008 certified.

Cover photo: Pixabay 


\section{Valuation of livestock eco-agri-food systems: poultry, beef and dairy}

\section{Authors}

W. Baltussen ${ }^{1}$, T. Achterbosch ${ }^{1}$, E. Arets ${ }^{2}$, A. de Blaeij $^{1}$, N. Erlenborn ${ }^{4}$, V. Fobelets ${ }^{4}$,

P. Galgani ${ }^{4}$, A. De Groot Ruiz ${ }^{4}$, R. Hardwicke ${ }^{5}$, S.J. Hiemstra ${ }^{3}$, P. van Horne ${ }^{1}$, O. A. Karachalios ${ }^{4}$,

G. Kruseman ${ }^{1}$, R. Lord ${ }^{5}$, W. Ouweltjes ${ }^{3}$, M. Tarin Robles ${ }^{5}$, T. Vellinga ${ }^{3}$, L. Verkooijen ${ }^{4}$

\footnotetext{
${ }^{1}$ Wageningen Economic Research

${ }^{2}$ Wageningen Environmental Research

${ }^{3}$ Wageningen Livestock Research

${ }^{4}$ True Price

${ }^{5}$ Trucost
} 


\section{Foreword}

Livestock has positive and negative externalities that impact economic and social systems and the ecosystem. TEEB for Agriculture \& Food developed a framework to assess these impacts. TEEB asked the consortium led by Wageningen University \& Research with participation of Trucost and True Price to give insight into these externalities for the livestock sectors. Other consortia executed similar studies for rice and maize.

We would like to thank Anne Mottet and Felix Teillard (FAO) for their support in data gathering and reviewing the draft final report. We would also like to thank Sandhu Harpinder (Flinders University) for his valuable comments on the draft final report and the discussion we had during the conference in Brussels in September 2015. TEEB subsidized the project.

We hope that the results of this study will be used by governments and firms in the livestock supply chains to improve their decision-making regarding future developments of livestock production systems all over the world.

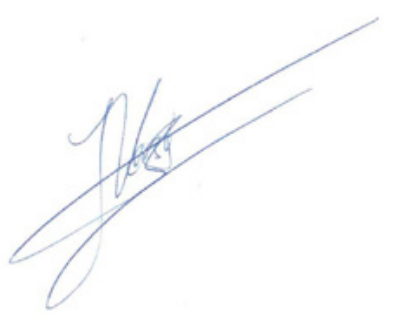

Prof.dr.ir. J.G.A.J. van der Vorst

General Director Social Sciences Group - Wageningen University \& Research 


\section{Contents}

(i) NOTE: This is an interactive PDF. It can be used as a normal PDF document and you can also move to another part of the document by clicking on the inserted 'links'. At the top of each page, you can switch to the table of contents, the previous page or the next page. With the $\Theta$ button you return to your former position.

\section{Summary}

\section{Introduction}

$>$

\section{Methods \& data}

\section{Top-down approach}

\section{Bottom-up analysis}

\section{Discussion}

\section{Conclusions}

\section{Recommendations}

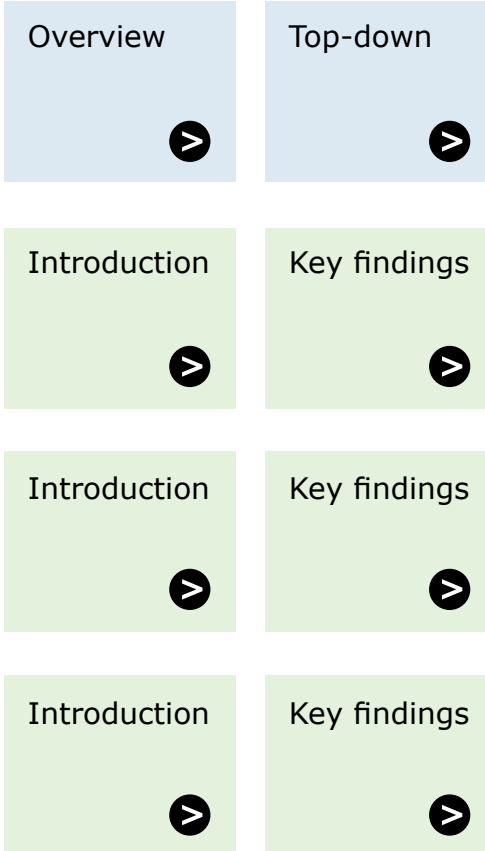

Bottom-up bottom-up

Top-down vs 


general poultry
beef
dairy
all

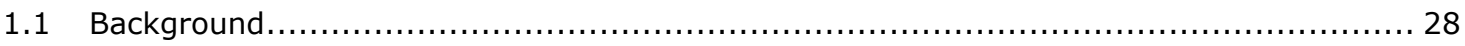

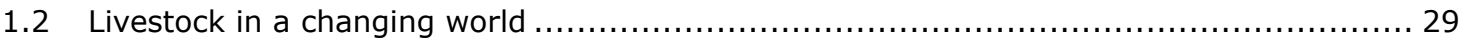

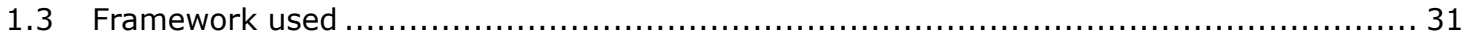

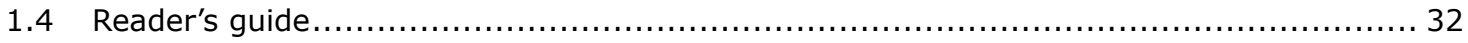

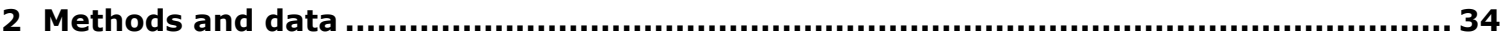

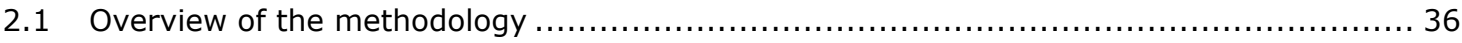

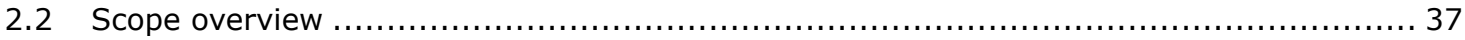

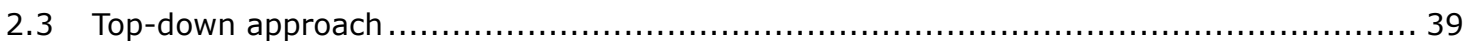

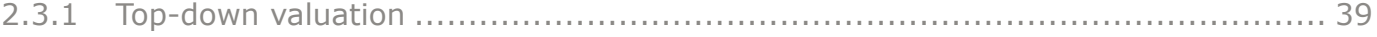

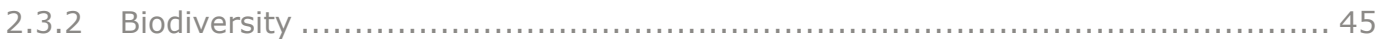

2.3.3 Animal and human health .............................................................. 45

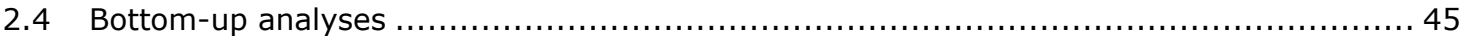

2.4.1 Methodological framework for impact assessment and valuation .....................45

2.4.2 Bottom-up quantitative impact assessment and valuation of snapshots............. 46

2.4.3 Data sources ............................................................................. 46

2.4.4 Mean species abundance of original species ........................................... 47

2.4.5 In-depth case study: Pastoralism in the Maasai Steppe, Tanzania...................... 48

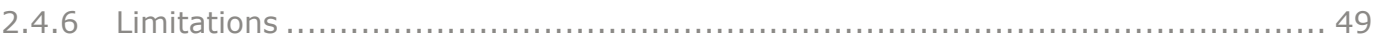

2.4.7 Snapshot selection of livestock production systems $\ldots \ldots \ldots \ldots \ldots \ldots \ldots \ldots \ldots \ldots \ldots \ldots \ldots, 49$

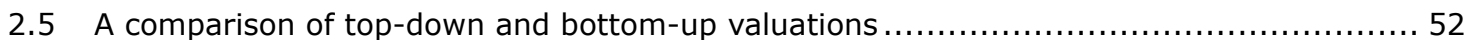

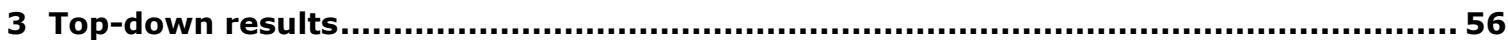

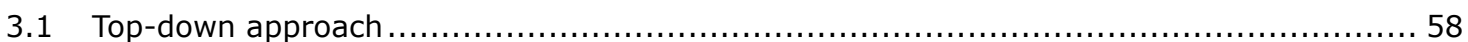

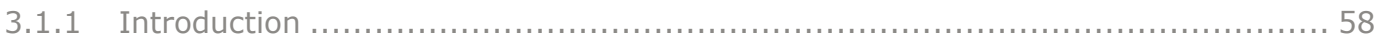

3.1 .2 Natural capital benefits .......................................................... 58

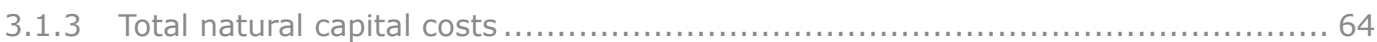

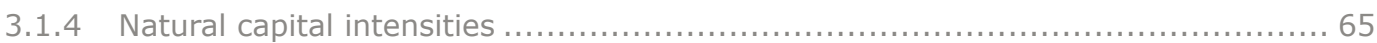

3.1 .5 Poultry meat production ............................................................. 67

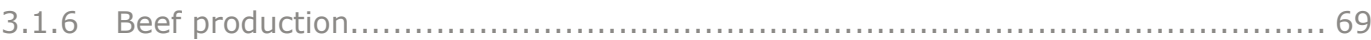

3.1 .7 Dairy milk production................................................................. 71

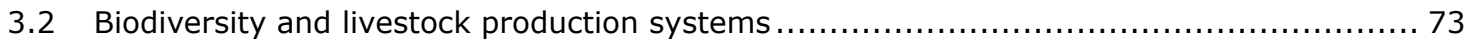

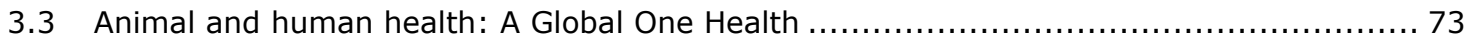

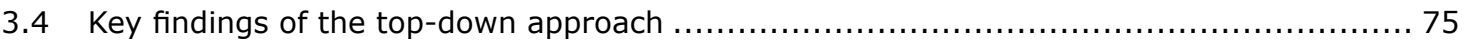

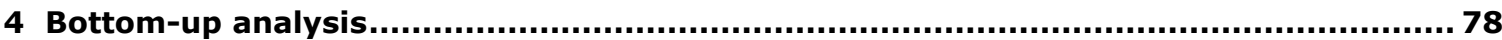

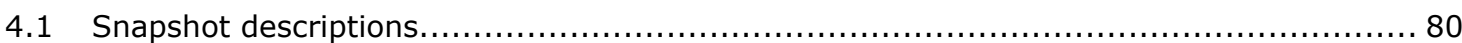

4.1.1 Snapshot 1: Tanzania backyard poultry ............................................ 80

4.1.2 Snapshot 2: Indonesia family farm broilers ........................................ 81

4.1.3 Snapshot 3: The Netherlands industrial broilers $\ldots \ldots \ldots \ldots \ldots \ldots \ldots \ldots \ldots \ldots \ldots \ldots \ldots . \ldots 3$

4.1.4 Snapshot 4: Tanzania pastoralist cattle........................................... 83

4.1.5 Snapshot 5: India pastoralist buffaloes............................................. 84

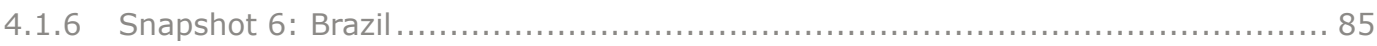

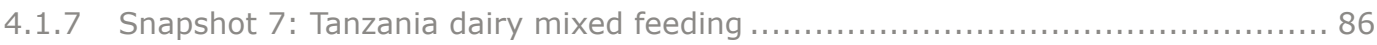

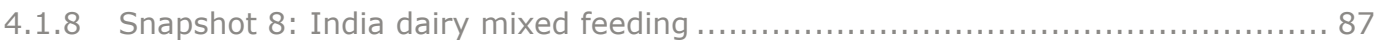

4.1.9 Snapshot 9: The Netherlands dairy specialized ................................. 87

4.1 .10 Snapshot 10 : Indonesia dairy mixed feeding $\ldots \ldots \ldots \ldots \ldots \ldots \ldots \ldots \ldots \ldots \ldots \ldots \ldots \ldots \ldots . \ldots \ldots$

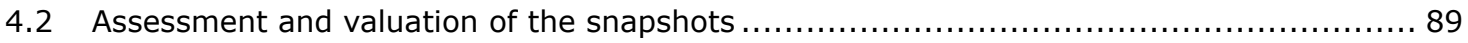

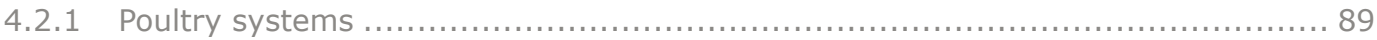

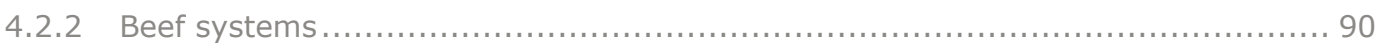

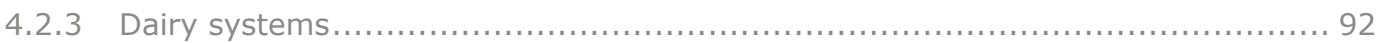




general poultry
beef
dairy
all

relation human / production system

relation production system /ecosystem

4.3 Bottom-up quantitative assessment and valuation at snapshot level .................... 93

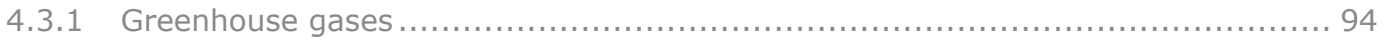

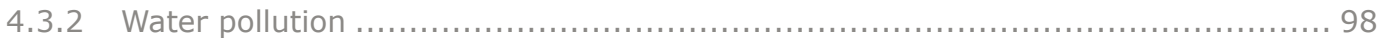

4.3 .3 Quantification of land occupation .................................................... 102

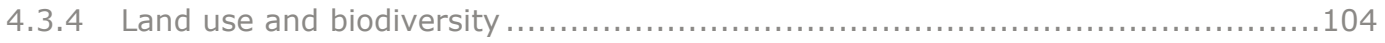

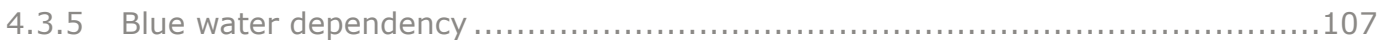

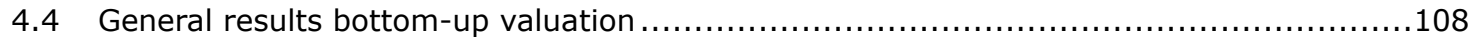

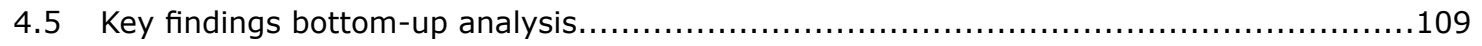

5 Landscape level valuation: Maasai pastoralism in Tanzania .................................. 112

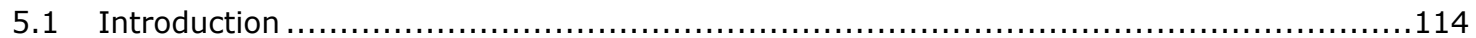

5.2 Context: the challenges of land conversion in the Maasai Steppe ...........................114

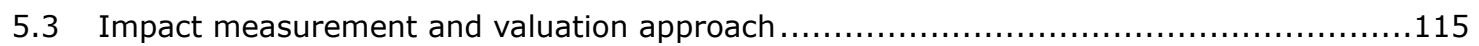

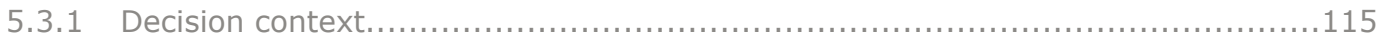

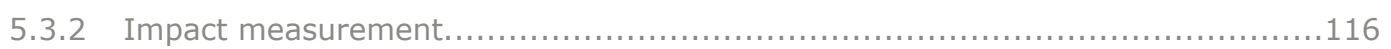

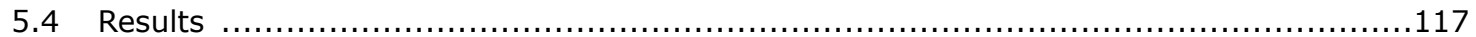

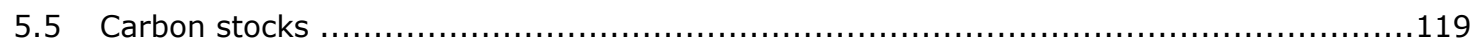

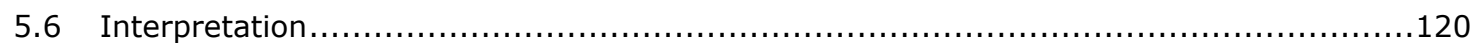

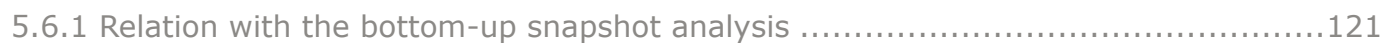

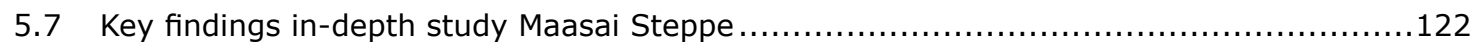

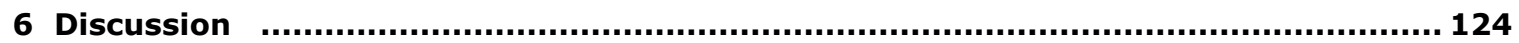

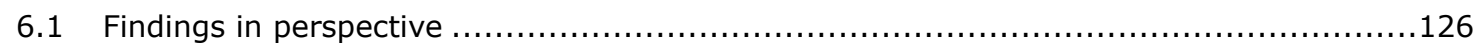

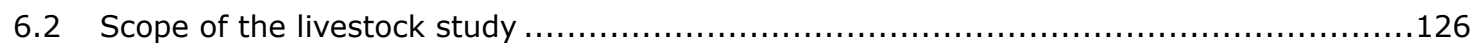

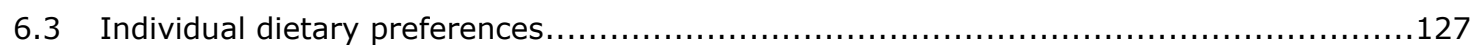

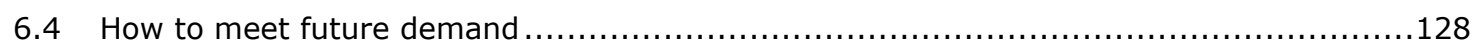

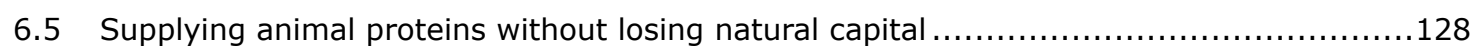

6.5.1 Scenarios show huge production increase in Africa....................................... 128

6.5 .2 People are moving to urban areas............................................... 130

6.5 .3 Response per species and snapshots.............................................. 130

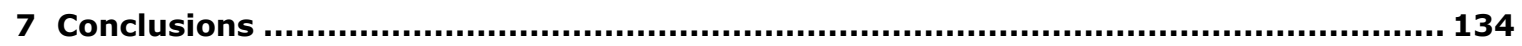

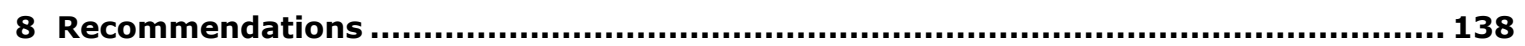

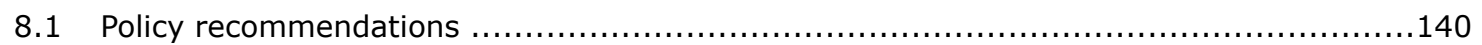

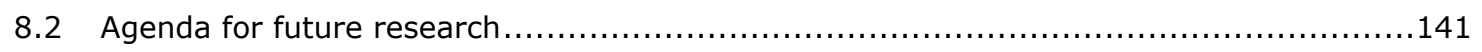

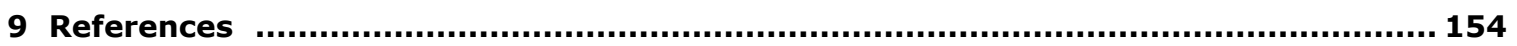

Annex A: Livestock production system indicators per snapshot................................ 156

Annex B: Comparison of bottom-up and top-down methodologies and results ............. 162 


\section{List of tables}

Table 1.1 Share of global production by livestock production systems in $\%$.........................29

Table 2.1 Scope of the assessment for the top-down and bottom-up by type of analysis ................38

Table 2.2 Global monetary valuation coefficients for natural capital impacts monetized in the analysis (in 2015 US\$ per unit)

Table 2.3 Range for the monetary valuation coefficients for natural capital impacts monetized in the analysis (in 2015 US\$ per unit)

Table 2.4 Natural capital costs and benefits that have been given a monetary value in this analysis.. 42

Table 2.5 Key inputs, outputs, costs and benefits of animal husbandry systems included in the top-down approach.....

Table 2.6

Summary of limitations for the valuations applied in the top-down approach

Key differences and similarities of top-down and bottom-up valuations.

Table 3.2 Retail price per kilogram of chicken, kilogram of beef, and litre of milk, as well as the value per kilogram of manure for the USA

Table 3.3 Ecosystem service benefits provided by livestock production systems (adapted from Hoffmann et al., 2014)

Table 3.4 Natural capital parameters for poultry meat production for the top-five contributing countries

Table 3.5 Natural capital parameters for beef production for the top-five contributing countries

Table 3.6 Natural capital parameters for dairy milk production for the top five contributing countries...

Table 4.1 Breakdown of GHG externalities for animal food products in the selected snapshots (USD/kg protein).

Table 5.1 Selection of ecosystem services quantified and valued

Table 6.1 Results:Supply of animal calories by region (in percentage increase 2000 to 2050).

Table 6.2 Results: Expansion of grassland and cropland (in percentage of increase per region as part of total increase in the world in SSP 2 'middle of the road') 


\section{Figure list}

Figure 1.1 Gridded Livestock of the World: Global distribution of a) cattle; and c) chickens; excluding South America and Africa. (source: Robinson et al., 2014) ......................30

Figure 1.2 TEEBAgriFood diagram showing the eco-agri-food system nexus

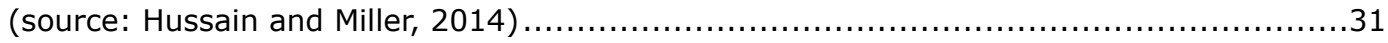

Figure 2.1 Overview of methodologies used to assess the impact of livestock production systems

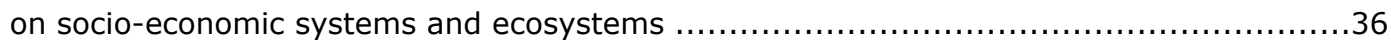

Figure 2.2 Scope of the assessment (adapted from Hussain and Miller, 2014) ............................

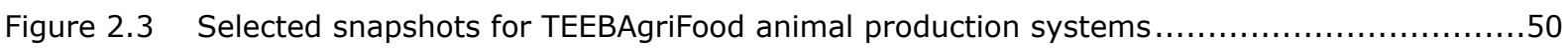

Figure 2.4 Possible development pathways for cattle and poultry production systems .................51

Figure 3.1 Total natural capital cost of beef, dairy and poultry production worldwide (in million US\$) and production quantities (in tonnes).

Figure 3.2 Average natural capital intensity split by natural capital impact of beef, poultry meat

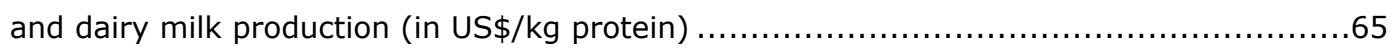

Figure 3.3 Poultry meat production for the top-five contributing countries, the EU28 and the rest

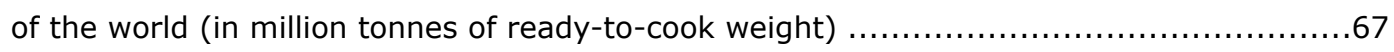

Figure 3.4 Natural capital intensity split by the type of natural capital impact of poultry production

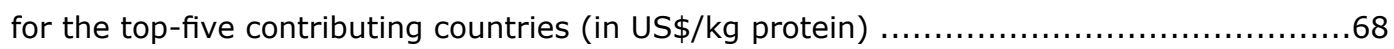

Figure 3.5 Beef production for the top-five contributing countries, the EU28 and the rest of the

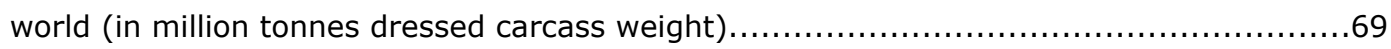

Figure 3.6 Natural capital intensity split by natural capital impact of beef production for the top-five

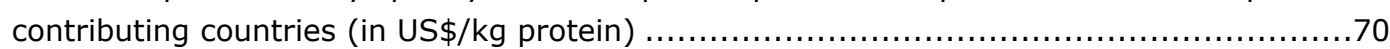

Figure 3.7 Dairy milk production for the top-five contributing countries, the EU28 and the rest of

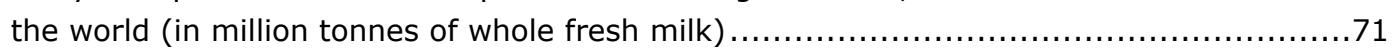

Figure 3.8 Natural capital intensity split by natural capital impact of dairy milk production

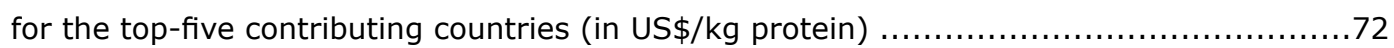

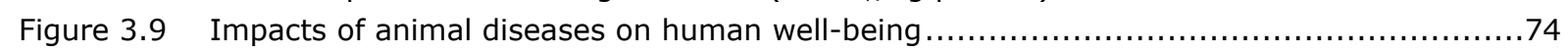
Figure 4.1 GHG externalities for animal food products in the selected snapshots (US $\$ / \mathrm{kg}$ protein).....94 Figure 4.2 GHG externalities for beef production systems in Brazil (US $\$ / \mathrm{kg}$ boneless meat) $\ldots \ldots \ldots \ldots . . . . .95$ Figure 4.3 GHG externalities for retail price comparison for poultry, milk and beef, respectively

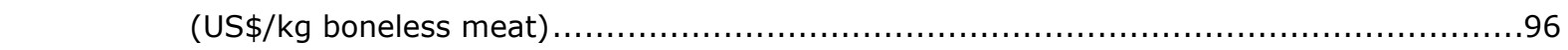

Figure 4.4 GHG externalities in pastoralist and mixed farming systems (US $\$ / \mathrm{kg}$ protein) ................97

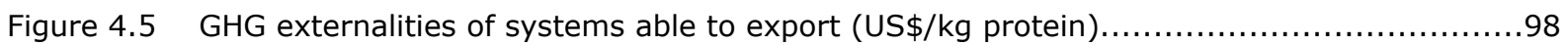

Figure 4.6 Water pollution costs for animal food products in the selected snapshots US $\$ / \mathrm{kg}$ protein...99

Figure 4.7 Water pollution costs for beef production in Brazil with efficiency improvements

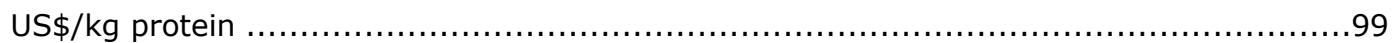

Figure 4.8 Water pollution costs in pastoralist and mixed farming systems (US $\$ / \mathrm{kg}$ protein) ...........100

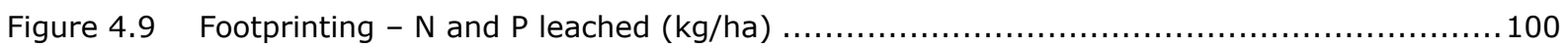

Figure 4.10 Water pollution externality compared to retail price for milk and beef production correspondingly (USD/kg bone-free meat or kg milk) ....................................... 101

Figure 4.11 Land occupation - poultry, beef and dairy snapshots ( $\mathrm{m}^{2} / \mathrm{kg}$ protein) ....................... 102

Figure 4.12 Land occupation - Brazilian beef production systems with different pasture management

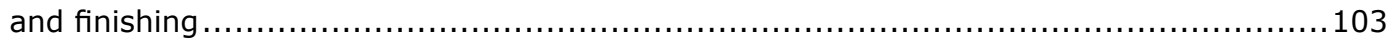

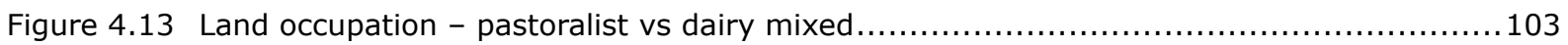

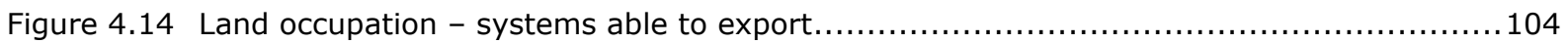

Figure 4.15 Impact of the use of pasture land on biodiversity for the different snapshot systems $\ldots . . .105$ 


\section{Figure list -2}

Figure 4.16 Impact of the use of land for feed production on biodiversity for the different snapshot systems

Figure 4.17 Total biodiversity footprint (MSA/ha: area needed per kg protein x MSA impact

Figure 4.18 Climate change footprint based on the total GHG emissions in the different livestock production systems

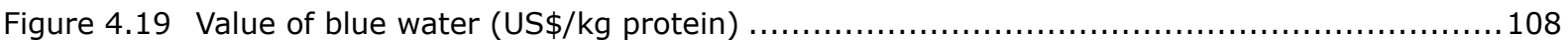

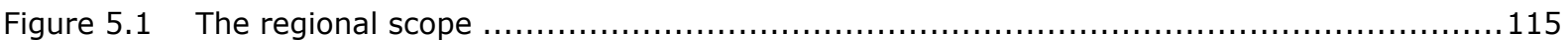

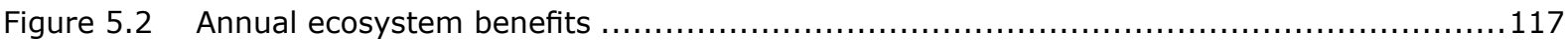

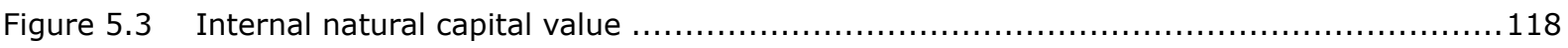

Figure 5.4 Value of carbon stock losses due to land-cover change in the Maasai Steppe, Tanzania (in billion USD)

Figure 6.1 Global consumption of meat and milk until 2030, based on calculation of FAO (2006) and if consumption in industrialized countries falls by $50 \%$ over that period Graph based on FAO (2006)....

Figure 6.2 Number of people living in rural and urban areas in Africa, Asia and Central and South America and in developed countries (Europe, North America, Oceania) (source: UN statistics, www.un.org)

Figure 6.3 Relation between output per cow and greenhouse gas emission (source: Gerber et al., 2011) 


\section{List of Abbreviations}

\begin{tabular}{|c|c|}
\hline AI & Artificial Insemination \\
\hline BFM & Bone Free Meat \\
\hline BRIC & Brazil, Russia, India and China \\
\hline CSO & Citizens Support Organization \\
\hline DALYS & Disability adjusted life years \\
\hline EEIO & Environmentally Extended Input Output \\
\hline EU & European Union \\
\hline FAO & Food and Agriculture Organization of the United Nations \\
\hline FCR & Feed conversion rates \\
\hline FMD & Foot and Mouth disease \\
\hline FPCM & Fat and protein corrected milk \\
\hline GDP & Gross domestic product \\
\hline GHG emissions & Greenhouse gases emissions \\
\hline GLEAM & Global Livestock Environmental Assessment Model \\
\hline IAWG & Interagency Working Group on Social Cost of Carbon \\
\hline IPCC & Intergovernmental Panel on Climate Change \\
\hline LEAP & The Livestock Environmental Performance and Assessment \\
\hline MSA & Mean Species Abundance of Original Species \\
\hline LCA & Life cycle analysis \\
\hline NGO & non-governmental organization \\
\hline OIE & World Organisation for Animal health \\
\hline PM10 & Particulate Matter up to 10 micrometers in size \\
\hline PPP & Purchasing Power Parity \\
\hline Q-fever & $\begin{array}{l}\text { Q fever is a disease caused by infection with Coxiella burnetii, a bacterium that affects } \\
\text { humans and other animals. }\end{array}$ \\
\hline SCC & Social Cost of Carbon \\
\hline SEEA & System for Environmental Economics Accounting \\
\hline SSP & Shared Socio economic Pathways \\
\hline TEEB & The Economics of Ecosystems and Biodiversity \\
\hline TEEBAgriFood & The Economics of Ecosystems and Biodiversity - Agriculture \& Food \\
\hline TSC & The Sustainability Consortium \\
\hline UNEP & United Nations Environment Programme \\
\hline USA & United States of America \\
\hline USD/US\$ or $\$$ & United States dollars \\
\hline US EPA & US Environmental Protection Agency \\
\hline VOC & Volatile Organic Compound \\
\hline WTP & Willingness to pay \\
\hline
\end{tabular}




\section{Natural capital valuation glossary}

\begin{tabular}{|c|c|}
\hline KEY TERM & DEFINITION \\
\hline Ecosystem services & $\begin{array}{l}\text { Ecosystem services are "the direct and indirect contributions of ecosystems to human } \\
\text { well-being" (De Groot et al., 2010). Examples of ecosystem services are food provisioning, } \\
\text { carbon regulation and recreation. }\end{array}$ \\
\hline Natural capital & $\begin{array}{l}\text { The naturally occurring living and non-living components of the Earth, together } \\
\text { constituting the biophysical environment, which may provide benefits to humanity (SEEA } \\
\text { definition). } \\
\text { Natural capital can also be defined as "the stock of natural ecosystems on earth including } \\
\text { air, land, soil, biodiversity and geological resources. This stock underpins our economy and } \\
\text { society by producing value for people, both directly and indirectly" (NCC, 2014). }\end{array}$ \\
\hline Externalities & $\begin{array}{l}\text { An externality arises when the actions of one economic agent in society impose costs or } \\
\text { benefits on other agent(s) in society, and these costs or benefits are not fully compensated } \\
\text { for and thus do not factor into that agent's decision-making (Hussain et al., 2014). } \\
\text { External costs and benefits are called respectively negative and positive externalities. }\end{array}$ \\
\hline Invisible costs and benefits & $\begin{array}{l}\text { These terms are used as synonyms for externalities. Cost and benefits are considered } \\
\text { invisible when not captured in the market. Examples of invisible costs and benefits relevant } \\
\text { for livestock systems are GHG emissions and pest control respectively. }\end{array}$ \\
\hline Visible costs and benefits & $\begin{array}{l}\text { Costs and benefits captured in the market. Examples of visible benefits relevant for } \\
\text { livestock systems are food provisioning and raw materials. Example of visible costs are } \\
\text { feed and labour costs. }\end{array}$ \\
\hline Natural capital benefits & $\begin{array}{l}\text { In the top-down analysis, natural capital benefits are the values provided by agricultural } \\
\text { and food systems, and by ecosystems and biodiversity to society. Natural capital benefits } \\
\text { can be invisible (such as pest control) or visible (such as food provisioning). }\end{array}$ \\
\hline
\end{tabular}

Natural capital costs or impacts Natural capital costs express in monetary terms the impacts on natural capital that are produced by livestock systems, as a result of resource use and pollutant emissions (units in \$). Natural capital costs captured in this study are external to the market, thus are invisible costs.

Natural capital intensities In the top-down analysis, natural capital intensities express the natural capital cost per protein content (units in $\$ / \mathrm{kg}$ protein). This metric allows identifying the commodity that provides the greatest amount of protein with the lowest impact on natural capital.

Operational costs Costs due to resource use or pollutant emissions that occur due to farming activities. For example, the use of farm machinery that runs on diesel will cause the emission of greenhouse gases.

Supply chain costs

Costs due to resource use or pollutant emissions that occur due to upstream supply chain activities, thus outside the boundary of the farm. In the context of this study, all of the impacts from the production of inputs to the farm are encompassed in the term 'supply chain costs'.

Natural capital dependencies

A dependency represents an ecosystem service that provides utility to an economic process, which is said to "depend" on natural capital. For example the use of water in irrigated farming is a dependency of agriculture on natural capital.

Natural capital value Natural capital value is the value of ecosystems and natural capital in a given area of land, as a capital asset. It is defined through its present and future benefits to people. When a specific geographical area is selected, the value of natural capital can be further differentiated between internal natural capital value, which represents the benefits to all local stakeholders within a region, and external natural capital value, which represents the benefits to all stakeholders outside of the region.

Ecosystem benefits In the approach used in Chapter 5 ecosystem benefits are defined as the benefits from ecosystem services enjoyed, consumed or utilized by beneficiaries on a specific area of land.

Ecosystem benefits constitute a subset of the value of final ecosystem services, that which is supplied by land and ecosystems, rather than by human inputs. 


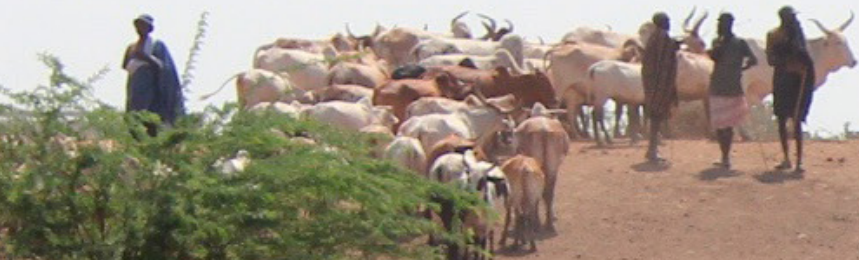

$$
\text { (6. }
$$

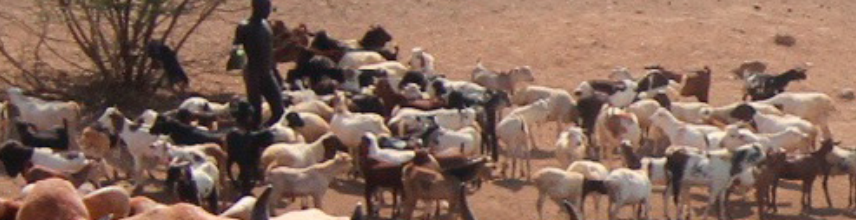

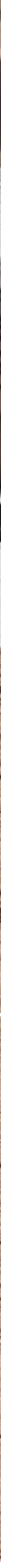



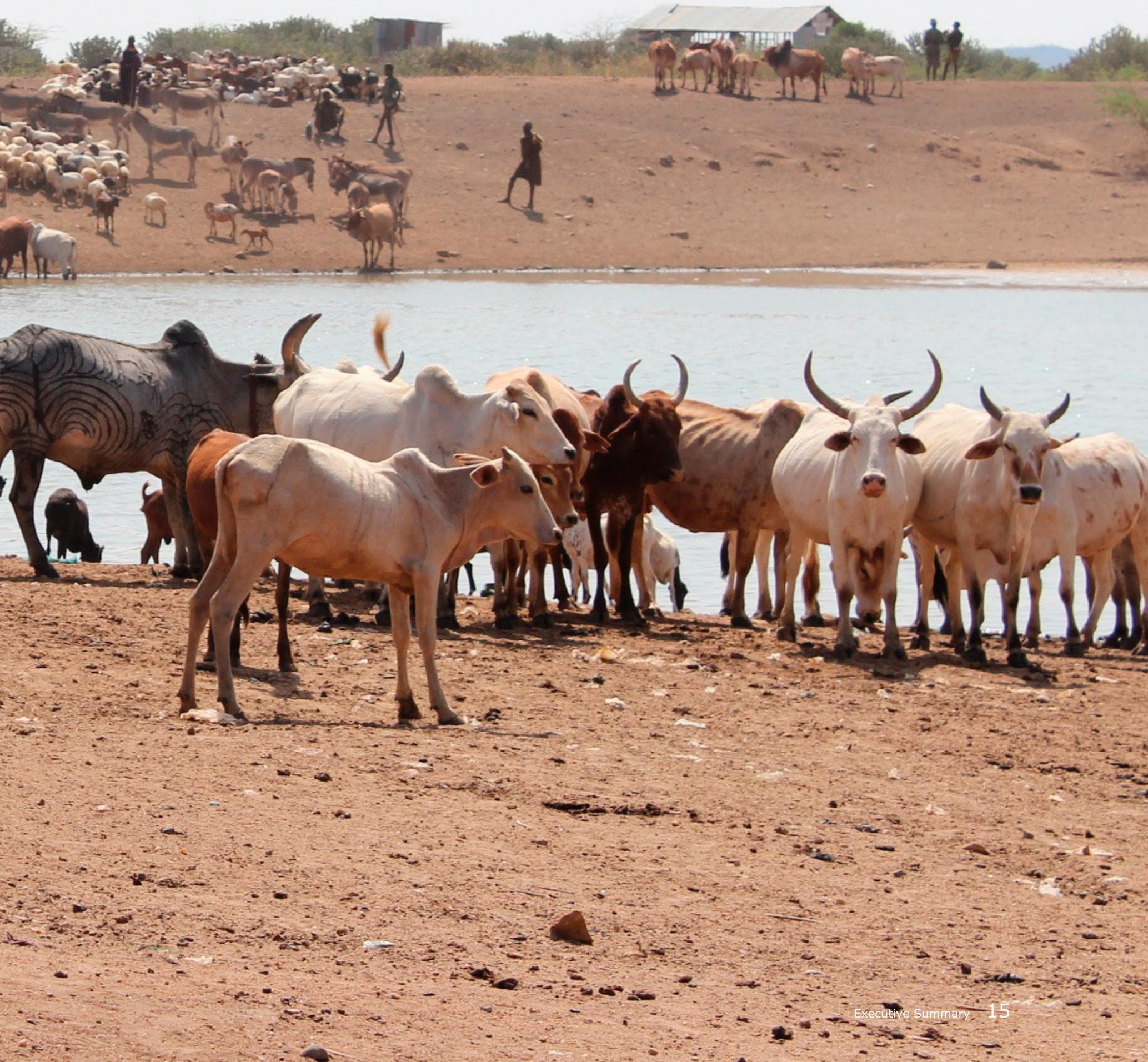


\section{Executive Summary}

\section{Introduction}

The Economics of Ecosystems and Biodiversity (TEEB) is a global initiative that helps decision-makers recognize the wide range of values, including economic, provided by ecosystems and biodiversity, so once those values are recognized they can filter down into decision-making. TEEB has conducted an agriculture and food study (TEEBAgriFood study) to bring together economists, business leaders, agriculturalists and experts in biodiversity and ecosystems to provide a comprehensive economic evaluation of eco-agri-food systems, and demonstrate that the economic environment in which farmers operate is distorted by significant externalities, both negative and positive, and a lack of awareness of dependency on natural capital. Indeed, a 'double-whammy' of economic invisibility of impacts from both ecosystems and agricultural and food systems is a root cause of increased fragility and lower resilience to shocks in both ecological and human systems.

As input for the TEEBAgriFood study, TEEB asked for a series of studies on livestock, rice, palm oil, inland fisheries and agro-forestry. This report deals with livestock production and aims to improve decision-making in livestock production policies, to enhance its viability, not just economically but also socially and environmentally. Livestock sector is important because they have high externalities and it is expected that livestock consumption will be $76 \%$ higher in 2050 compared to 2005 (Alexandratos and Bruisma, 2012) because of population growth, income growth, urbanization and preference shifts. This report aims to provide evidence that will help to identify policy options for the transition towards increased food security with sustainable livestock production systems, with particular emphasis on the role of smallholder farmers.

This study started with the following specific research objectives:

- Assess the visible and invisible values of biodiversity and ecosystems to the various types of agriculture systems (inputs) and evaluate the scale, range and degree of both positive and negative impacts of livestock production systems on ecosystems, health and livelihoods (outputs);

- Explicitly address the role of smallholder farming, and contrast it with an assessment of one large-scale system;

- Use a differentiated approach that looks at major segments of society, such as rural and urban populations, developed and developing countries, as well as gender;

- Include Tanzania as a study site for the purpose of evaluating a pastoralist system in order to complement the TEEB Tanzania country study.

\section{Method}

The aim of this study is to assess the positive and negative socio-economic and environmental effects of livestock production systems, from both global and national perspectives, using a methodology based on a framework developed by TEEB. The methodology is driven by the notion that the valuation of the costs and benefits derived from livestock can be approached in two ways: a topdown approach and a bottom-up approach (see figure S.1). The valuation of costs and benefits follows the principles of environmental economics, implying that those aspects are quantified in economic terms.

The top-down approach is a high-level analysis that identifies key geographical hotspots and material natural capital impacts. The top-down analysis is a valuation for the production of each commodity at a country level, with no differentiation between farming systems. This type of analysis makes it possible to determine the impact of livestock sectors worldwide. In this sense, a top-down 


\section{TEEB framework}

Overiew of agro-eco-food system linkages

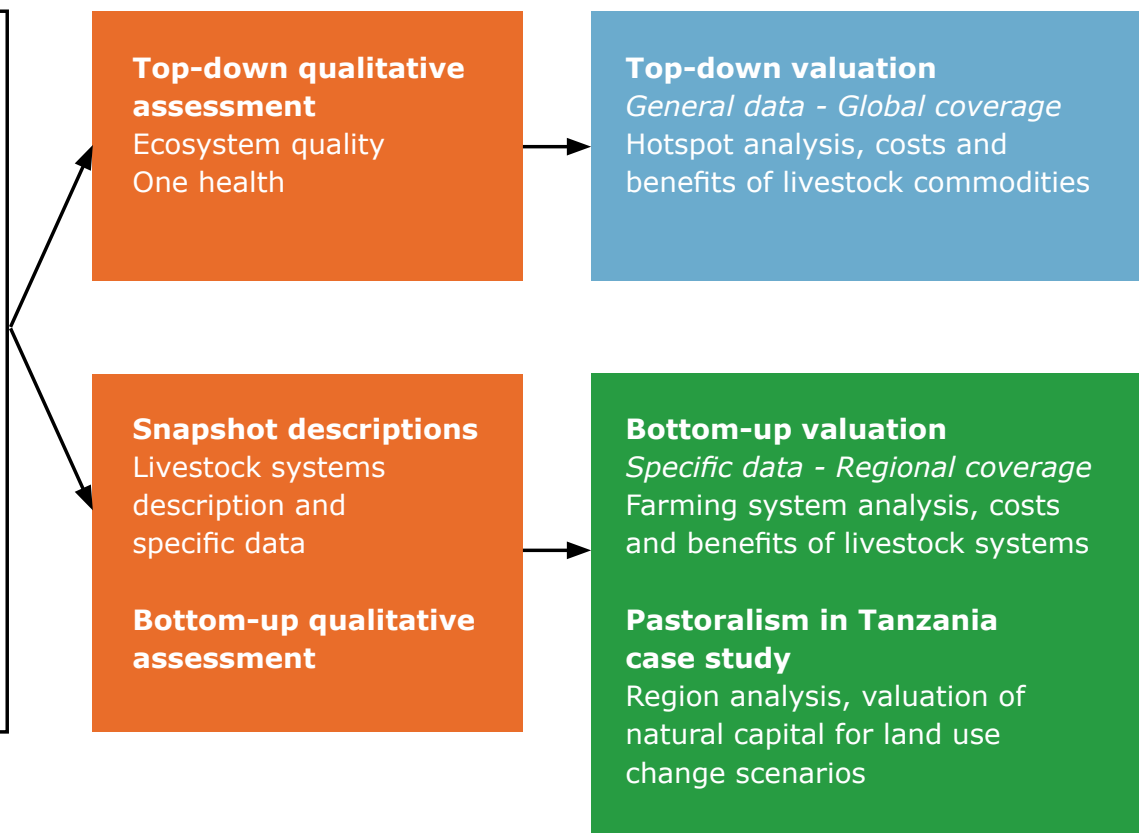

Figure S.1 Overview of methodologies used to assess the impact of livestock production systems on socio-economic systems and ecosystems.

approach can be informative for decision-making with a large geographical scope.

The bottom-up approach goes into more detail and complements than the top-down approach. The bottom-up approach assess the impacts upstream till farming gate and excludes the impacts from processing and consumption. Therefore, the authors have selected a set of livestock production systems for poultry, beef and dairy called 'snapshots'. Data are collected and used in the analysis to monetize the economic, social and environmental values and impacts of the different livestock production systems.

\section{Findings}

The findings are divided and presented by method, beginning with the findings from the top-down approach, and followed by the ones from the bottom-up approach. Finally, the case study is provided.

\section{Findings from the top-down approach}

Natural capital costs

- Natural capital costs express in monetary terms the impacts on natural capital that are produced by livestock systems, as a result of resource use and pollutant emissions (units in US\$). Natural
A bottom-up approach can act as the foundation for decision-making within a specific geographical scope. This report also uses an in-depth case study to look at natural capital-human systems linkages for one of the selected livestock production systems (pastoralism in Tanzania) in a holistic manner. This analysis quantifies many dependencies on ecosystem services simultaneously and looks at local externalities using a time-explicit model. The in-depth case study is an example of how a detailed bottom-up valuation can show the invisible value of natural capital to the human economy in a given region.

capital costs include the impact of supply chain (upstream) and operational (farming) activities on six natural capital impact categories: GHG emissions, air pollutants, water consumption, water pollutants (from fertilizers application), soil pollutants (from pesticides application) and land-use change.

- The total natural capital cost of beef, dairy milk and poultry meat have been calculated by considering all producing countries, and thus represent the impacts of those sectors at a 
global scale. Beef production is the sector with the greatest impact on natural capital worldwide. The annual total natural capital cost of beef production (which is $1.5 \mathrm{US} \$$ trillion) is three times higher than that of dairy milk production (0.5US\$ trillion) and approximately six times higher than that of poultry meat production (almost 0.26US\$ trillion).

- For all producing countries, the share of the operational impact to the total natural capital cost is approximately $78 \%$ for beef, $65 \%$ for dairy milk and $29 \%$ for poultry meat. Thus for beef production the natural capital impact is mainly associated with the direct operations, while for poultry it is mainly associated with the upstream supply chain. This can be attributed to the lack of enteric fermentation, the low land requirements for poultry production associated with its direct operations, and the higher use of feed cultivated off farm and thus acquired as part of supply chain activities. Compared to beef, for dairy milk production the higher impacts occur in the supply chain as dairy systems rely more on purchased feed than beef systems, which have a greater impact on the supply chain.

- The share of the total global natural capital cost for the top-five contributing countries is $50 \%$ for beef (Brazil, United States, China, Argentina and Mexico); 39\% for dairy milk (United States, India, Brazil, China, Russian Federation); and $43 \%$ for poultry (United States, Brazil, China, Indonesia, Russian Federation). EU28 contributes $8 \%, 19 \%$ and $11 \%$ of the total natural capital cost of beef, dairy milk and poultry production respectively. This estimate is only for upstream and production and does not include consumption.

- Variation in natural capital costs between countries can be explained by:

- The total number of animals under production;

- Efficiency of livestock production systems (resource use or emissions per tonne of production);

- Natural capital valuation coefficients (for example, the value of the ecosystems present in the country).

\section{Natural capital intensities}

- Natural capital intensities express the natural capital cost per protein content (units in US\$/kg protein). This metric makes it possible to identify the commodity that provides the greatest amount of protein with the lowest impact on natural capital.
- When determining the average natural capital intensity (considering all producing countries), beef has a higher natural capital intensity than poultry. This result is caused by higher GHG emissions and land-use change associated with beef production.

- The average natural capital intensity of EU countries is lower than the global average. This is partly due to a more efficient production system.

\section{Types of natural capital impacts}

- For beef and dairy milk, land-use change is the most important natural capital impact (contributing $72 \%$ and $62 \%$ of the natural capital intensity, respectively) followed by greenhouse gas emissions ( $20 \%$ and $22 \%$, respectively) when considering all producing countries. In the case of poultry meat, GHG emissions (39\%) and land-use change (36\%) represent the largest natural capital impact.

- The contribution of water pollution, water consumption and soil pollutants is on average small compared to the other impacts, in total less than $5 \%$ of the total natural capital costs for all species.

\section{Benefits}

- The provision of food represents one of the most significant benefits to society provided by livestock. Furthermore, livestock systems can enhance a wide range of regulating, supporting and cultural services, for example soil carbon sequestration (regulating service), the connection of habitats for plant species through seed dispersal in seasonal grazing systems (supporting service) and the enrichment of cultural identity through the role of livestock in social and spiritual activities (cultural service).

\section{Biodiversity impacts and dependencies of livestock} production

- Livestock production affects biodiversity in many different ways, the impact of which differs in type and magnitude depending on local conditions. The impact is predominantly negative, although some positive externalities exist as well, especially in extensive livestock grazing systems, such as pastoralism. Yet local management practices can be used to alleviate the negative impacts or restore biodiversity.

\section{One health: animal and human health}

- Livestock production systems have a huge direct and indirect impact on human health. This 
impact can be a positive or negative externality. Animal protein is an important part of the human diet. Zoonoses (animal diseases) can endanger human health, as can the use of antibiotics in animal production systems.

- Good indicators to quantify the relation between animal diseases and human health are currently lacking. This is partly due to a lack of knowledge and data in both the developed and developing world. However, sufficient information is available to underpin the above statements.

- The relation between animal health and human health can differ among species which can influence the hidden costs per species.

\section{Findings from the bottom-up approach}

Following are the key findings of the bottom-up analysis of ten livestock production systems in four countries:

\section{Overall findings}

- The environmental externalities of animal protein production are a large invisible cost. The comparison of carbon externalities with the retail price of livestock products shows that these can account for $1 \%-143 \%$ for beef, $19 \%-161 \%$ for milk and $19 \%-37 \%$ for poultry. Water pollution costs go from less than $1 \%$ to up to $25 \%$ of the product prices and show a high variability due to local environmental conditions. This implies that diversity is high but society as a whole nevertheless pays a significantly larger price for animal protein consumption than the retail price paid.

- Beef farming has much larger natural capital costs per kg of protein compared to poultry farming; mixed dairy farming, which also produces beef, has lower external costs than pure beef farming. This holds for all the environmental impacts considered, namely greenhouse gases (GHG), land occupation and water pollution.

- Chicken meat production requires the smallest amount of land per unit of animal protein produced because of its favourable feed conversion rate and absence of grazing. Mixed systems in dairy farming also occupy relatively smaller amounts of land, especially where productivity is high or reliance on grazing and imported feed is low. Extensive cattle systems result in the highest land occupancy as their primary source of feed is pasture grazing. Indeed, some of these areas, used by extensive cattle systems, support no other agricultural activity. However, land occupancy can be better understood if viewed alongside the impacts on biodiversity and local communities that each production system has within its specific region.

\section{Snapshot findings}

- The production of beef as a 'side' product of intensive dairy farming with a high animal replacement rate is an alternative comparable to poultry in terms of the low impact on natural capital. This system, explored in its Dutch variation, appears to have land occupation and GHG emissions comparable to poultry, due to the system's high efficiency. There are two important caveats to this conclusion: the first is that the quality of meat produced in this system may not be comparable to that of pure beef-focused extensive systems, and it is more suitable for ground meat products. The second conclusion is that due to the high animal density, and import of nutrients, the Dutch system has a high water pollution cost and a very high nutrient leaching per hectare, the largest of all snapshots. A low water pollution cost per unit of output still translates into a very high nutrient load per hectare.

- The study of alternative beef systems in Brazil shows that improved pasture management and finishing in feedlots can reduce GHG natural capital costs by up to $20 \%$ and land use by $37 \%$. An analysis of water pollution externalities reveals that while improved pasture management reduces water pollution, finishing in feedlots increases it compared to pure grazing systems. The net result is still positive for finishing in feedlots.

- Backyard chicken rearing is found to have an environmental profile similar to that of more developed poultry systems, in terms of GHG emissions and water pollution, while it provides animal proteins at a lower cost in terms of land occupation and blue water use*.

\footnotetext{
Water use is often split into green water, blue water and grey water. The blue water footprint refers to the volume of surface and groundwater consumed (evaporated) as a result of the production of a good; the green water footprint refers to the rainwater consumed. The grey water footprint of a product refers to the volume of freshwater that is required to assimilate the load of pollutants based on existing ambient water quality standards (see Mekonnen and Hoekstra, 2010)
} 
- Pastoralist systems generally have lower natural capital efficiency than other cattle systems, and land requirements are especially high. However, as opposed to feed-based or pasture-based systems, pastoralism can reap benefits from semi-natural ecosystems without seriously negatively affecting biodiversity and natural capital, as highlighted by the in-depth case study on pastoralism and landscape preservation in Tanzania.

\section{Biodiversity impacts and dependencies of livestock production}

- Livestock has both a direct and indirect impact on biodiversity. The direct impact through trampling and grazing and defecation appears to be smaller than the indirect impact through land-use change (deforestation) and intensification of the land use creating homogeneous pastures for grazing and croplands for feed production, and climate change resulting from emissions of methane and other greenhouse gases.

- In poultry, and more intensive industrial-scale livestock production systems, the relation between land use and its impact is more obscure. Although these systems are sometimes called 'land-less' production systems, this is a misleading term. These systems still rely on (distant) cropland for production of the concentrated feed they import, spatially disconnecting the livestock and an important part of its impacts.

- Intensification of livestock production is an important trend resulting from the increasing demand for animal protein. Intensification involves a further concentration of resources (financial, labour and nutrient inputs) to produce more livestock on the same unit of land. As a result, intensification can influence livestock's impact on biodiversity and natural capital in different ways. Locally the impact of more intensive production will increase; at the same time demand for feed will increase, leading to a higher distant impact. If, however, this increase in intensity is accompanied by better production efficiency, i.e. more kilograms of protein (or meat, milk or eggs) per unit of input, then the overall biodiversity impacts per unit of protein product may decrease. Because it is not always possible to increase efficiency, as it depends on factors like local growing conditions, this does not mean that intensification is a solution under all circumstances.

\section{Animal and human health}

- There is variation in the use of antibiotics within and between species. In general, intensification of livestock production goes hand in hand with an increase in the use of antibiotics, and in poultry antibiotics are used more frequently than in cattle production per $\mathrm{kg}$ of protein produced. However, there are mitigation strategies that enable a mix of intensive production and low input of antibiotics.

- Zoonoses exists in all regions and animal production systems. The impact of food-borne diseases and non-alimentary zoonoses (like Q-fever in the Netherlands) is more or less unknown.

\section{Findings from the case study}

Following are the findings from the case study on pastoralism and landscape preservation. They add an additional layer to the bottom-up valuation of the snapshot regarding the pastoralist beef system in Tanzania. An analysis of the internal value of natural capital takes a regional approach to provide a closer look at what other benefits pastoral rangeland ecosystems provide to human populations in the Maasai Steppe, beyond meat and milk production. The expansion of farmland brings income to settlers, both traditionally nomadic local populations and migrants from other regions, but it has a negative impact on pastoralists and wildlife. Cropland encroaches upon migratory routes and the most fertile grazing areas are claimed by agriculture. Furthermore, as land in the Maasai Steppe is generally arid and not particularly suited for farming or keeping concentrated livestock, agriculture is characterized by low productivity and declining soil fertility.

- The discounted internal natural capital value (discount rate $=3 \%$ ) of the Maasai Steppe, valued looking at final ecosystem services to the Tanzanian population, is estimated to be US\$2.7 billion if the conversion from pastoral rangeland to mixed crop and cattle farming occurs at high speed, US $\$ 3.3$ billion if it occurs at medium speed, and US\$4 billion if it occurs at low speed.

- Livestock production provides the largest share of benefits from ecosystems for the local population in the Maasai Steppe. Pastoralism and sedentary farming both contribute equally to this value creation, mainly through food production, although skins and hides are also marketable products.

- Two other large components of natural capital value in the region today are contributions to crop farming and tourism. A literature study 
reveals that these two activities are in competition, as expansion of farmland threatens wildlife migration corridors, negatively affecting animal populations, which in turn have significant touristic value.

- Other forms of direct value creation from ecosystems and biodiversity are raw materials, wild food such as vegetables and roots, medicinal herbs, drinking water, and forest products such as timber, charcoal, firewood, tree gum, honey and beeswax. These goods have a lower market value but can still constitute an important means of subsistence for the local population.

- A comparison of three scenarios of land conversion from rangeland to mixed crop and cattle farming at different speeds reveals that a faster conversion from pastoralism to agriculture leads to less ecosystem value in the long run, although farming has the highest value in the short term. This result is attributable to the negative effect of mixed crop and cattle farming on pastoralist access to grazing lands and on wildlife populations in national parks, together with the unsustainability of current mixed arable livestock systems in the region.

- Additionally, carbon emissions due to land-use changes are also an important externality of conversion of rangeland to agriculture, estimated to range from US\$15 billion in a low speed scenario to US\$24 billion in the high speed scenario. Expanding the analysis to carbon stocks confirms that the interests of the global communities are aligned with the local community, as global communities will also benefit from a slower rate of conversion.

\section{Conclusions}

The livestock sector is a major contributor to the global ecological footprint. The global demand for animal products will grow further in the next decades due to expanding human populations and the average increase of meat consumption per person. Existing scenarios estimate global demand in 2050 to be $150 \%$ to $200 \%$ of what it was in 2010.

The question is whether this growth will further deplete natural capital worldwide, or whether we will be able to enhance the production of animal protein and simultaneously reduce the loss of natural capital. This study - the first of its kind to apply natural capital valuation on a large scale to livestock production worldwide - analyses cattle and poultry production at a global level but also in different countries for specific production systems, climatic zones and under different levels of intensification. The impact of livestock systems on social, economic and environmental issues has been quantified where possible. When there is no reliable data, the authors provide a qualitative assessment based on scientific literature.

The big picture is clear: animal products are under-priced. Climate change, the loss of ecosystems, water pollution, and the impact of water shortages are only some examples of the costs derived from livestock production that were calculated in this study and are ultimately borne by society. We estimated these costs for cattle and poultry to be $2.28 \times 10^{12}$ US $\$$ per year $(2.28$ US\$ trillion) worldwide, most of it due to beef production.

In order to understand the implications of this growth we have to analyse specific livestock systems in more detail. The implications for natural capital of high-input, specialized livestock systems on the medium and large scale are reasonably well documented and understood. These systems reach high productivity levels and rely largely on external inputs, such as purchased feed, capital and medicines. These highly specialized systems could potentially feed large urban populations as they can be easily scaled up.

It is well known that the production of chicken and milk proteins have a much lower natural capital impact than the production of beef per $\mathrm{kg}$ of animal protein, so it is likely that internalizing external natural capital costs would shift diets towards poultry and dairy. At the same time, there is room for livestock systems to reduce the natural capital costs per kilogram of protein, especially for smallholder livestock systems, which are a major contributor to the world's food supply. The more intensive dairy systems are more efficient at this moment but also more closer to maximum efficiency and the potential for improvement are therefor less. 
We found substantial diversity in the regions we studied in terms of productivity, impact on climate, water quality and biodiversity, as well as a high potential for improvement. This potential can be realized by understanding the options available based on local conditions, measuring the impacts and developing and disseminating best practices. Local conditions that should be taken into account include access to markets, inputs and knowledge, but also local climate, local ecosystems and availability of crop residues. Especially in ruminant systems, there is a double benefit, because intensifying systems will increase production and reduce the GHG emissions per unit of product. Thus, food security and mitigation can go hand in hand with livestock intensification in many smallholder systems the output can be strongly increased by small increase in inputs (like knowlegde, feed or antibiotics). This is especially the case for smallholder systems in Asia and Africa.

This study also looked at several subsistence systems. Pastoral cattle and backyard poultry do not require much input, but have a low output level per animal and low efficiency per kilogram of protein. However, not only do subsistence systems supply food to the most vulnerable populations, they are also well adapted to local constraints, have many side benefits for local poor communities, and usually have a very low or even positive biodiversity impact. Though these aspects of subsistence livestock production are not yet well understood, they are important. For example, a case study of the Maasai Steppe in Tanzania showed that pastoralism can conserve measurable ecosystem services and natural capital value, especially if the alternative is farming that will eventually lead to land degradation. The pastoralist systems are under pressure, especially in rural areas in developing countries. The importance of subsistence systems for the poor should be made visible in more contexts and basic improvements in terms of food security and productivity should be pursued.

The message is clear: the growth of the livestock sector presents many risks for natural capital, but there is much that can be done to tackle these risks. It is possible to produce animal products for the world population without losing this form of wealth, if the right path is followed. First, natural capital has to be fully measured, as its visibility is a requirement for its conservation. Second, a single livestock production system alone cannot supply animal products to the whole world. The entire range of livestock systems would need to contribute to feed the future world population with animal proteins. Therefore, the right improvements need to be identified and pursued for each context, using a suitable, location-specific approach. The links between livestock, ecosystems and society needs to be valued and understood at the regional level. Finally, livestock systems are key components of agro-ecosystems and under specific management practices can enhance the provision of ecosystem services. Therefore, mechanisms have to be developed to internalize external costs and encourage good agricultural practices, without affecting food security for the poor. Internalization will help market forces to steer the food sector down a more sustainable path, where natural capital wealth is leveraged to create wealth for the current as well as future generations.

\section{Policy recommendations}

Based on these findings, we have identified the following policy recommendations:

\section{Pay the full price without affecting food security}

- Negative externalities should be internalized in the price of animal products, without affecting food security. This can be done, for example, via voluntary commitments, environmental taxation or environmental regulation. However, these measures should not increase food prices for vulnerable shares of the population. Internalization of negative externalities will help to steer the livestock sector down a path that minimizes the loss of natural capital.

- The positive externalities of livestock production - from managing landscapes to supplying organic fertilizer, from animal traction to fulfilling cultural functions - should be rewarded. These rewards should at least consist of fully recognizing any type of social cost-benefit analysis, and at best offer payment for ecosystem services schemes. If positive externalities remain invisible and co-benefits are not encouraged, desired improvements of agricultural systems may lead to unwanted side effects. If invisible but important positive externalities disappear, as a result of agricultural develop- 
ment, the economic losses for the beneficiaries of these co-benefits could be larger than the benefits due to these innovations.

\section{Consolidate valuation of natural capital}

- An important requirement for internalization is that natural capital be consistently measured. Governments should encourage dialogue between different stakeholders, such as international organizations, NGOs, companies and investors, in order to create a standardized valuation framework that would make it possible to monetize different costs and benefits that affect human well-being as well as the ecosystem and biodiversity. This framework will make it possible in the future to simultaneously capture the hidden costs and benefits of livestock systems and the visible costs and benefits, and that, in turn, has given decision-makers the opportunity to start embracing sustainable livestock production practices. The Livestock Environmental Performance and Assessment (LEAP) project aims to build consensus between different stakeholders (governments, the private sector, NGOs and CSOs) on how to measure the environmental impact of livestock. Furthermore, the Natural Capital Coalition and The Sustainability Consortium (TSC) are great examples of progress in this regard, which can be applied to different industry sectors, not only livestock.

\section{Improve livestock production systems}

- Scenario studies show that increased animal protein production is possible without increasing natural capital costs. Governmental environmental programmes and reduction initiatives should focus on material natural capital impacts identified in this study, such as GHG emissions, land use and water pollution. In this sense, developing and promoting good agricultural practice could contribute greatly to reducing the impact of livestock. For example, improving manure management or animal diet would decrease GHG emissions of livestock. On the other hand, avoiding the excessive fertilization of feed crops (for example through precision agriculture) as well as promoting appropriate manure management would decrease nutrient run off and thus pollution of water bodies associated with livestock production.

- One of the most important options is increasing the production per unit of land and per animal, so more animal proteins can be produced with less input, such as water, minerals, antibiotics, land and energy. This would also decrease the natural capital costs per kilogram of animal protein. Sometimes, improving efficiency goes hand in hand with an increase in scale of farms and the risks of increasing negative impacts like the leaching of minerals, the misuse of antibiotics, or the outbreak of zoonotic diseases. For example it was highlighted that in the case of Brazilian grass-fed cattle, the introduction of a finishing period in feedlots can increase output and improve GHG and land intensity, but it would also have some costs related to additional water pollution. Good farming practices like improving pasture management, improving animal health or soil fertility management where feed is produced, should be put in place to increase the production without increasing the negative impacts. Improvement options for smallholders must be assessed and identified on a regional basis. In general, technical knowledge should be shared between countries with dedicated platforms, so that the good technology and good farming can be applied to decrease natural capital impacts. Special attention should also be given to the adaptability of those techniques to local conditions. This is particularly important as several BRIC and developing countries are becoming key worldwide livestock producers as a result of rising incomes. For example, Brazil and China are key global contributors to the total natural capital cost for the three livestock commodities analysed, partly due to high production quantities.

\section{Healthy diet: our role as consumers}

- Governments should start a dialogue on the links between consumer behaviour, change in diets and natural capital preservation. According to the results of this study, diets that would substitute beef with chicken consumption are beneficial from a natural capital point of view. This holds at the margin until the point where grassland has no alternative agricultural use. 


\section{Agenda for future research}

This study has tried to help answer the question how we can sustainably feed the global population with animal proteins without increasing natural capital costs. Still, this question has many more dimensions than those addressed here. Future research should continue to look systematically at the positive and negative impacts on natural capital of livestock production value. This will require expanding the scope and including in the equation issues that have been left out until now. The extended TEEBAgFood framework can be used as a basis to guide an economic evaluation of the eco-agri-food system as a complex, highlighting economic distortions, hidden external costs and dependencies on natural systems. The framework overcomes the problems of seeing nature, agriculture and the food system as distinct from each other by mapping their interconnections in a comprehensive way.

Following are some important questions that need to be addressed in the future:

- This study has focused on livestock production systems worldwide. The next step is to systematically compare alternative livestock systems and potential improvements, because it will yield insights that can be directly used in decision-making. Substitutability happens when systems operate in the same geography or produce the same products for the same market and one can be scaled down and the other scaled up to some extent.

- This study has highlighted the fact that livestock production exists not only in complex interrelation with natural ecosystems, but also with nearby and faraway crop systems. Looking in more detail at mixed arable livestock systems as a whole can reveal the full benefits of integrating these two activities, which is common practice for smallholder farmers all over the world. This type of complex research faces methodological and data availability challenges, but offers a unique perspective in linking food production and natural capital regeneration from an economic, ecologic and agronomic perspective.

- Smallholder agriculture feeds a significant part of the world population, but whether and how this can be leveraged for natural capital conservation and enhancement is not always clear to policymakers. Research linking the economic and social development aspects of smallholder agriculture with environmental considerations is necessary in this regard. Monetary valuation is one of the key tools to understand and compare these interrelations. We recommend integrating economic, social, and environmental aspects in research on smallholder agriculture in the same way as it is often performed in family and large scale farming. This kind of research would be useful in understanding the costs and benefits of intensification and examining trade-offs between income and natural capital.

- Not only can livestock and agricultural systems provide food, but they can also manage landscapes to increase their value in multiple ways. The innovative land valuation framework applied to East African pastoralism can be applied to investigate the value of natural capital assets in other agricultural, natural and semi-natural ecosystems. Research that seeks to systematically identify and calculate the internal and external natural capital value of key food-producing regions in the world and the value of sustainable landscape management should be strengthened. This requires additional efforts to gather reliable regional data on the natural goods and services grown and used on a specific type of land (provisioning ecosystem services such as water supply and agricultural products) and of the sustainability over time of these benefits (related to deforestation, water stress and land degradation trends). 


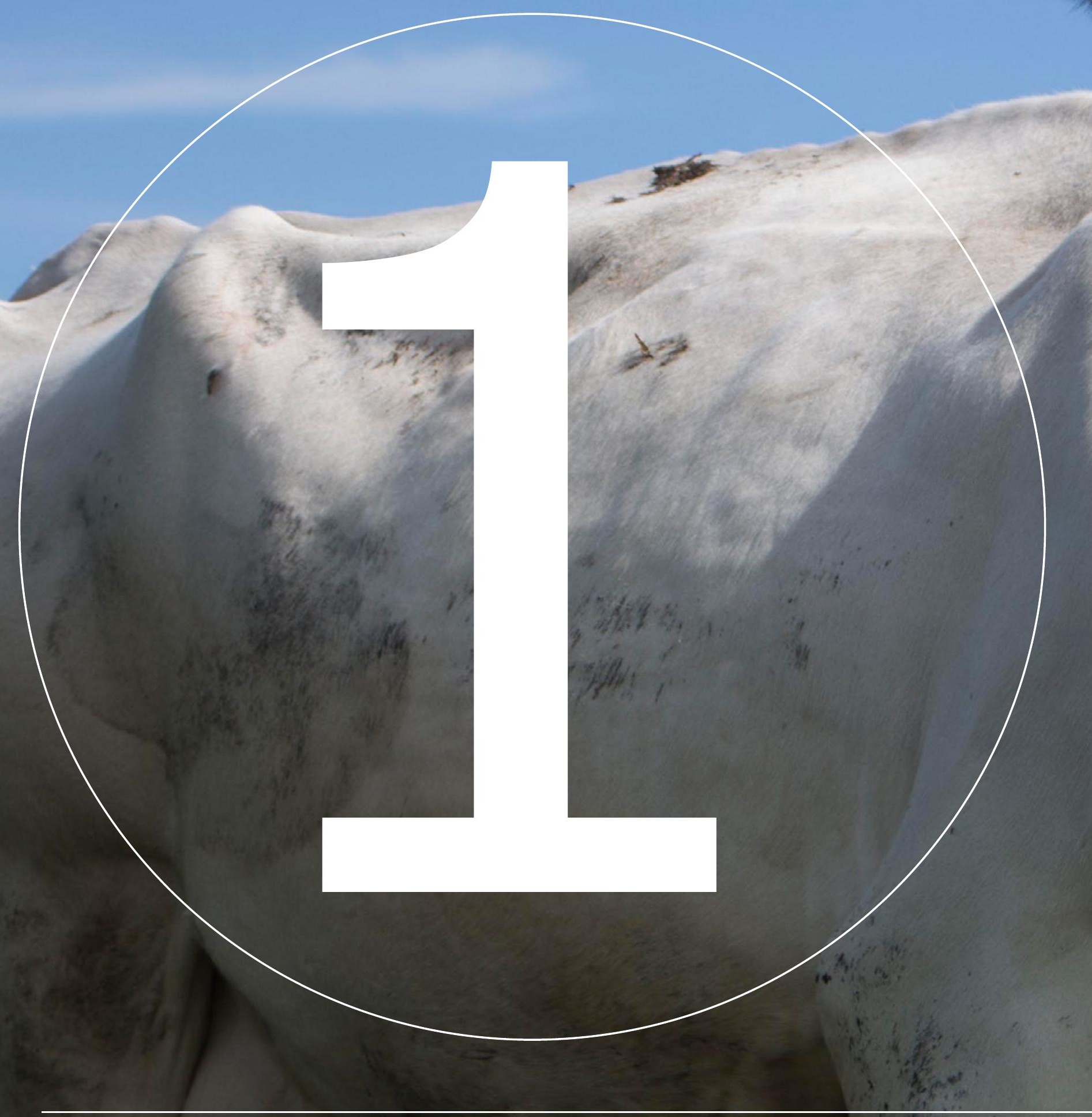

\section{Introduction}




\section{Introduction}

\subsection{Background}

The Economics of Ecosystems \& Biodiversity $(T E E B)^{1}$ is a global initiative helping decision-makers to recognize, demonstrate and capture values of ecosystem services and biodiversity. Ecosystem services are the direct and indirect contributions of ecosystems to human well-being (Kumar, 2010). The TEEB study on Agriculture and Food (TEEBAgriFood) was designed to make the natural capital inputs as well as the externalities of agri-food systems 'visible'. More specifically it was designed to demonstrate that the economic environment in which farmers operate is distorted by significant externalities (both negative and positive), and a lack of awareness about high dependency on natural capital. ${ }^{2}$

A 'double whammy' of economic invisibility of impacts from both ecosystems and agri-food systems is the root cause of increased fragility and lower resilience to shocks in both ecological and human (economic and social) systems (see Hussain and Miller, 2014). As input for the TEEBAgriFood study, TEEB asked for a series of studies on livestock, rice, palm oil, inland fisheries and agro-forestry. This report deals with the study on animal husbandry and aims to improve decision-making concerning livestock production policies, to enhance its viability, not just economically but also socially and environmentally. This study will provide the necessary evidence to identify policy options for transitioning towards increased food security with sustainable livestock production systems, with particular emphasis on the role of smallholder farmers.

Specific research questions in the Terms of Reference included:

- To assess the visible and invisible values of biodiversity and ecosystems in the various types of agriculture systems (inputs) and evaluate the scale, range and degree of both positive and negative impacts of livestock production systems on ecosystems, health and livelihoods (outputs);

- The role of smallholder farming needs to be explicitly addressed; besides small-scale production, a contrasting large-scale system also needs to be assessed;

- A differentiated approach by major segments of society, such as rural and urban populations, developed and developing countries, as well as gender; and

- Study sites still need to be chosen, but they should include Tanzania for its pastoralist system evaluation.

In order to do this, we have mapped, visualized and valorized the use of natural capital inputs, and assess the negative and positive externalities of livestock production systems, on a global level and also for several specific livestock production systems in specific countries ('snapshots').

This chapter will first describe consumption and production trends (section 1.2), followed by an introduction to the TEEB framework (section 1.3). We used the TEEB framework of 2014. In the meantime this framework has been extended to include the entire value chain. This is the major framework used in this study to assess all positive and negative relations between livestock production systems, on the one hand, and the human (economic \& social) system and ecosystems and biodiversity, on the other hand. The structure of the report is outlined at the end of the introduction.

2 Natural capital can be defined as 'the stock of natural ecosystems on earth including air, land, soil, biodiversity and geological resources. This stock underpins our economy and society by producing value for people, both directly and indirectly' (NCC, 2014). This implies that impacts on natural capital include impacts on society (human health) and on ecosystems. 


\subsection{Livestock in a changing world}

Animal protein, minerals and vitamins are an important part of the human diet and will probably become even more important in the future. The main drivers that will increase demand for animal products in the future are income, population growth and urbanization. The expected increase in demand for animal products between 2000 and 2050 is about $19 \%$ to $37 \%$ per capita as a result of higher incomes, though these figures also depend on the scenario used (Animalchange, 2012). Global population growth - which is expected to increase from about 6.9 billion people to 8.5 and 10 billion between 2010 and 2050 - will further increase demand (estimates range from an increase of $46 \%$ to $99 \%$ ). This projected increase in demand can be met in two ways: by increasing efficiency (producing more animal proteins with less inputs) and by expanding production (numbers of animals). Which of the two pathways will be dominant also depends on yield development and crop prices as shown by Havlik et al. (2013). Havlik et al. (2013) estimate that presently about $5 \%$ of the milk produced is $100 \%$ grass fed; $70 \%$ is produced in mixed systems (grass, crops and crop residues) and $25 \%$ in other systems, i.e. mainly in commercialized landless systems ('footloose') and to a much smaller extent in systems based on scavenging and residues ('backyard'). For beef production these percentages are $22 \%, 56 \%$ and $22 \%$, respectively. In a baseline scenario (identified as 2030-B, in table 1.1 below), which assumes there will be an increase in crop yields, the contribution of grass-fed systems is expected to decline and the contribution of the mixed systems is expected to increase. If there is no expected increase in crop yield (scenario 2030-50 in table 1.1), then an increase of the grass-fed system is expected for milk and beef production, while the additional contribution of mixed will be more limited.

Table 1.1 Share of global production by livestock production systems in \%

\begin{tabular}{lllllll} 
& Milk & & \multicolumn{2}{c}{ Ruminant meat } \\
& Grass & Mixed & Other & Grass & Mixed & Other \\
\hline 2000 & 5.2 & 70.3 & 24.5 & 21.8 & 56.1 & 22.1 \\
\hline $2030-S O$ & 8.9 & 75.2 & 15.9 & 27.4 & 57.7 & 14.9 \\
\hline $2030-B$ & 2.8 & 81.3 & 15.9 & 19.0 & 66.0 & 14.9 \\
\hline
\end{tabular}

Source: Havlik et al. (2013)

Figure 1.1a shows that in 2006 global cattle production was highly concentrated in the Midwest of the US, Brazil, sub-Sahara region in Africa, Europe, India and the western part of China. Figure 1.1c shows that poultry production was highly concentrated in the west of the US, in the south of Brazil, in the west sub-Saharan region in Africa, in India, in the west of China and in Indonesia. Besides the industrial production of broilers in the US, Europe and Brazil, in many regions of the world most chickens are kept in small-scale and backyard production systems. There are several ways of enhancing food security and meeting the growing demand for livestock products. These options have different economic, social and environmental impacts, however. Policy-makers at the national, regional and global levels need to make choices to enhance food security without compromizing ecosystem quality and integrity, and to integrate economic, social and environmental values.

At the global level trends in consumption per head and population growth differ between regions. For Europe and the United States, for example, consumption per head is expected to decrease in the coming decades and population growth is expected to be near to zero. The demand for animal protein is expected to decrease in this part of the world. Africa, however, expects higher incomes and substantial population growth. These trends will dramatically increase the demand for animal protein. Given the fact that the present levels of production of meat, milk and eggs are low in Africa it will be a challenge to increase the availability of animal products to meet the increasing demand. Present import levels related to production and consumption are low in Africa (see Herrero et al., 2014). 
There are essentially three development options:

a Produce the feed and animal protein in the same country or continent. This means that the area for agricultural production has to increase substantially, as does the efficiency of growth in terms of crop production and animal production;

b Produce animal protein in the country or continent and import the feed or feed ingredients from other countries or continents;

c Import animal products from other countries or continents, which may make other countries more dependant.

The Animalchange scenarios (Animalchange, 2012) show that consumption and production are expected to grow in Africa, India, Indonesia and Latin America. These are also regions with vulnerable and valuable ecosystems and biodiversity (e.g. compare with Myers et al., 2000 or Newbold et al., 2015).

$1.1 \mathrm{a}$

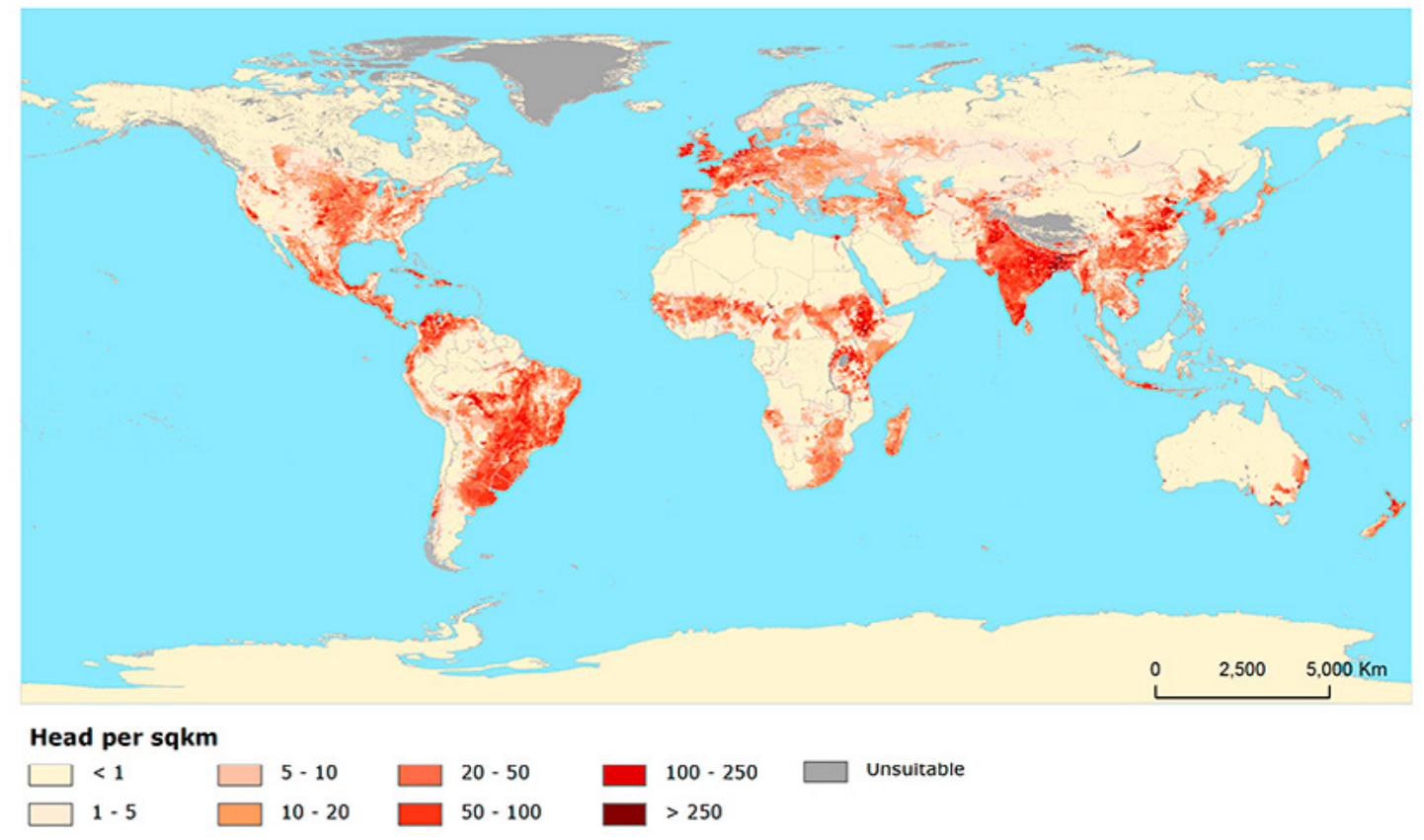

$1.1 \mathrm{c}$

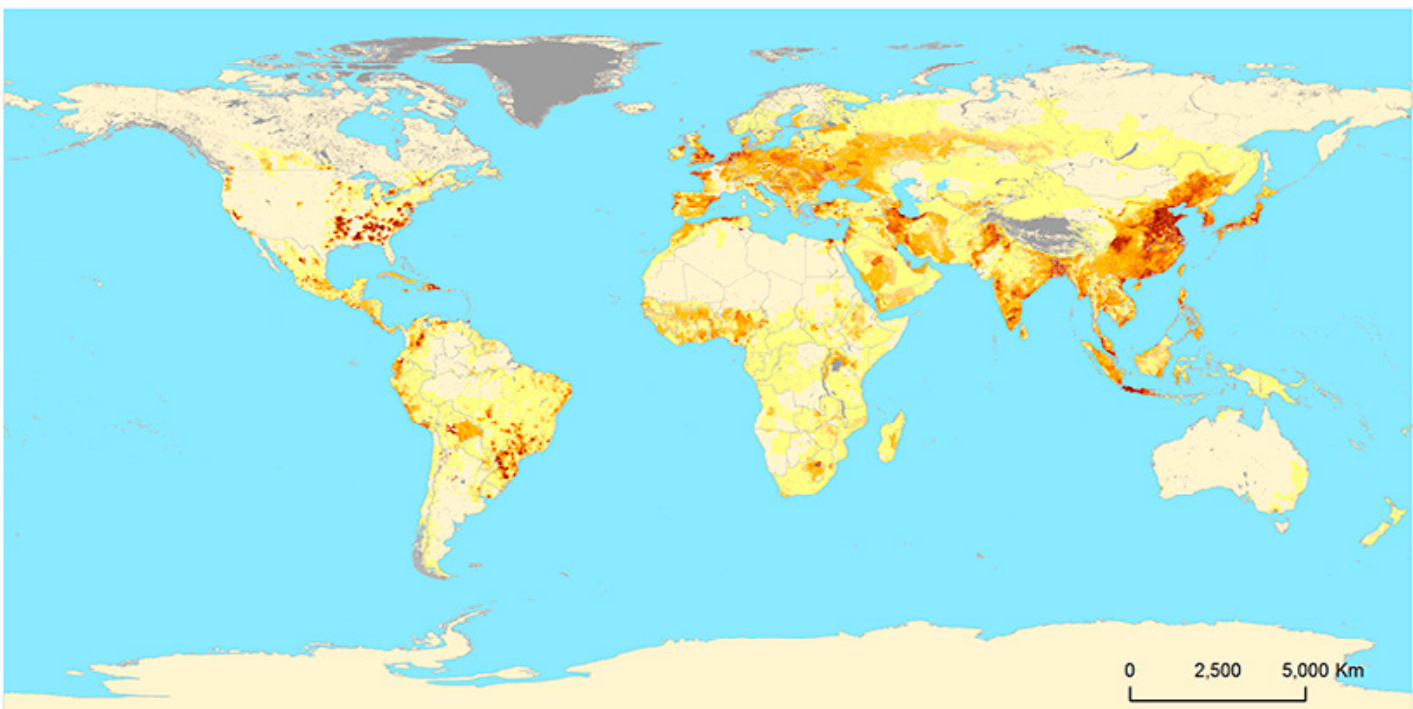

\section{Birds per sqkm}

$\square<1 \quad \square=0-100 \quad \square 250-500 \square$
$1-50 \square 100-250 \quad \square$
$\square=00-1,000 \square$
$2,500-10,000$

Figure 1.1 Gridded livestock of the world: global distribution of a) cattle; and c) chicken; excluding South America and Africa. Source: Robinson et al. (2014) 


\subsection{Framework used}

The aim of this study is to assess the positive and negative socio-economic and environmental effects of livestock production systems, from both global and national perspectives, using the methodology and framework as developed by TEEB (Hussain and Miller, 2014). Figure 1.2 summarizes and visualizes the links between agri-food systems, human systems, and ecosystems and biodiversity. Chapter 2 ('Methods and data') explains how this framework is used to assess the different livestock production systems.

This study combines two types of approaches to provide a view of natural capital externalities and dependencies of the livestock sector: a top-down and a bottom-up approach. The top-down approach provides a general assessment of the natural capital impacts of selected livestock sectors, highlighting key natural capital aspects and geographical hotspots. The bottom-up approach analyses specific kinds of animal husbandry systems in their geographical and socio-economic context, assessing different typologies of farms. While the first approach allows a broad geographical coverage and identifies hotspots but also the impacts of the sector worldwide, the latter enables the comparison of specific farming systems and the incorporation of region-specific nuances. Throughout the report, the first type of valuation will be referred as 'top-down valuation', while the latter as 'bottom-up valuation'. Chapter 2 presents and compares the two valuation approaches.

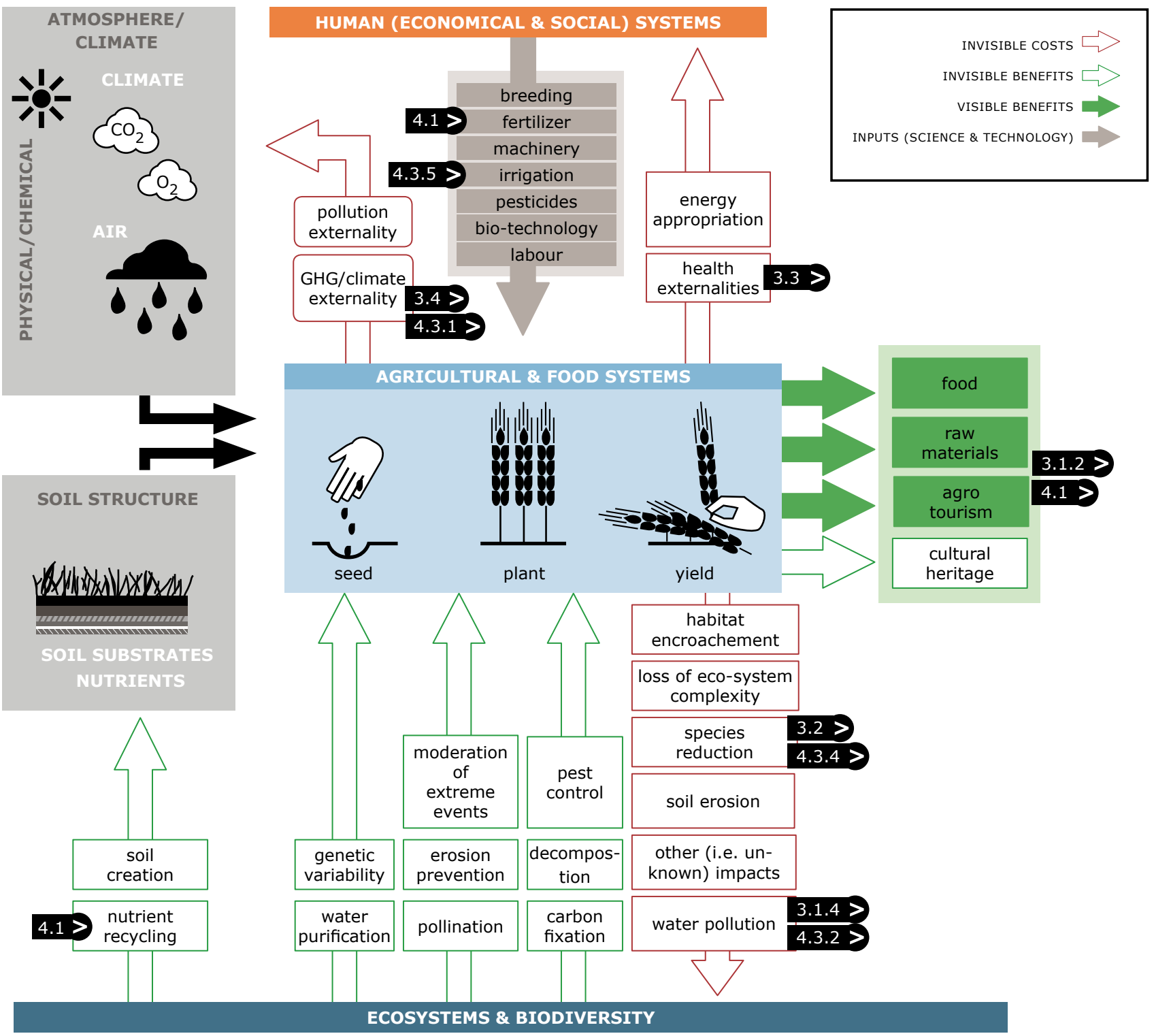

Figure 1.2 Framework showing the eco-agri-food system nexus (source: Hussain and Miller, 2014) 


\subsection{Reader's guide}

The structure of the report is as follows. Chapter 2 describes the methodology and data used in detail. This chapter explains the complementary top-down and bottom-up approaches to assess livestock production systems on their negative and positive externalities. Chapter 2 also explains the criteria used for the selection of livestock production systems and regions/countries for the purpose of this study.

Chapter 3 presents the results of the top-down assessment. This chapter starts with a top-down approach, which: 1) briefly describes qualitatively the benefits provided by livestock systems in terms of different ecosystem services, and in the case of food provisioning and manure, those benefits are also monetized, 2) provides the monetization of the natural capital costs of beef, dairy milk and poultry meat production from a global perspective. The top-down assessment also contains a general description of the relationship between biodiversity and livestock production systems, and a qualitative analysis of the relationship between animal production system and human health.

In Chapter 4 selected 'snapshots' (combinations of region/countries and livestock production system) are presented and described in detail. Information on environmental inputs, and negative and positive externalities associated with livestock production systems is presented in this chapter. Part of the list of externalities has been assessed qualitatively (no indicators available or no info available to quantify the indicators), while other externalities have been quantified (i.e. land use) and/or valued (i.e. greenhouse gases; blue water use ${ }^{3}$ and water pollution). For every snapshot, the limitations of intensifying its current state is analysed (i.e. by producing in the same livestock production system more outputs with the same input).

Chapter 5 analyses in detail the value of the Maasai Steppe in Tanzania under different scenarios. The biodiversity of this region has been used because the region is not heavily populated, the number of relevant economic activities now and in the future is limited and the ecosystem is relatively uniform given the area taken into account.

Chapters 6 to 8 contain the discussion, the conclusions, policy recommendations and recommendations for future research. 


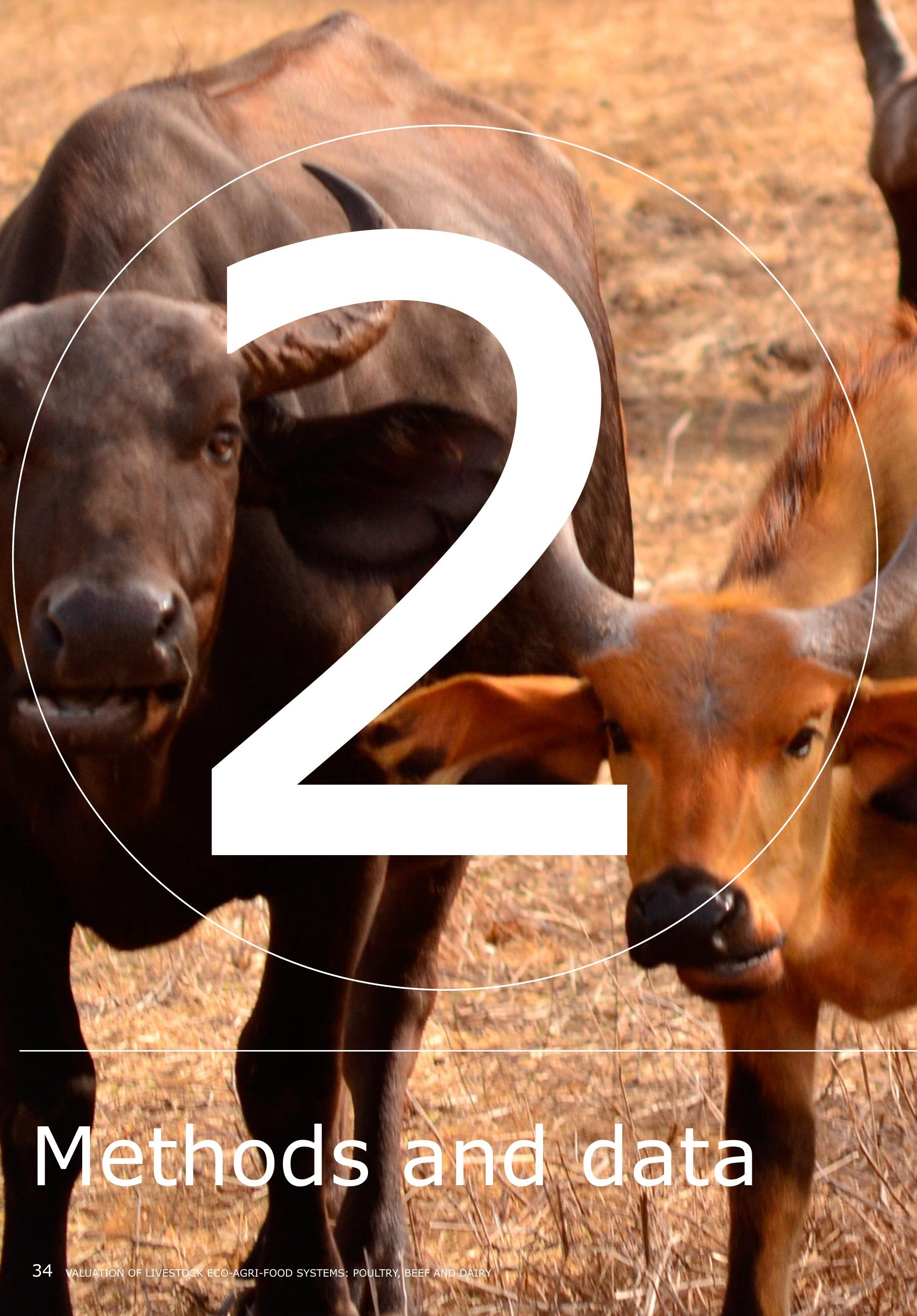


2.1

Overview of the methodology

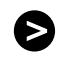

2.2

Scope overview

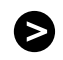

2.3

Top-down approach

$\nabla$

2.3.1

Top-down valuation
2.3.2

Biodiversity
2.3 .3

Animal \& human

$\nabla$

\section{$\nabla \quad \begin{aligned} & \text { Animal } \\ & \text { health }\end{aligned}$}

\section{4}

Bottom-up analysis

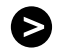

\section{4 .1}

Methodological framework for impact assessment and valuation

2.4.4

Mean species abundance of original species

\section{4 .2}

Bottom-up

$\nabla \quad$ quantitative impact assessment and valuation of snapshots

\section{4 .5}

In depth case study: Pastoralism in the Maasai Steppe, Tanzania

\subsection{7}

Snapshot selection of livestock production systems

\section{4 .3}

Data sources

$\nabla$

$\nabla$

\section{4 .6}

Limitations

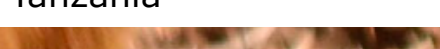

\section{5}

A comparison of top-down and bottom-up valuations

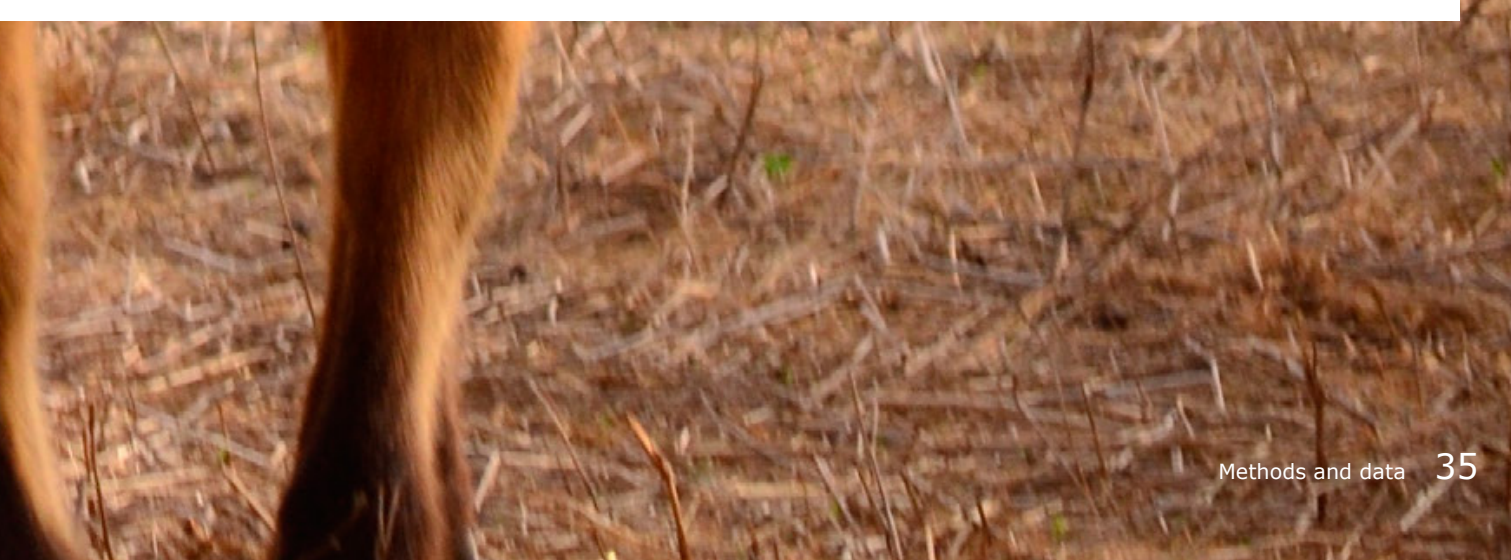




\section{Methods and data}

\subsection{Overview of the methodology}

The methodology followed in the analysis is based on the TEEB framework as described in chapter 1 . This is a very comprehensive framework. To assess all the aspects it covers and how they interrelate would require a wide set of data. In many regions of the world these data are not available or only to a limited extent and are of poor quality. This implies that not all relationships can be analysed to the same degree. Section 2.2 will provide an overview of the degree to which relationships have been analysed. The TEEB framework is in the centre of the methodology as depicted in figure 2.1 .

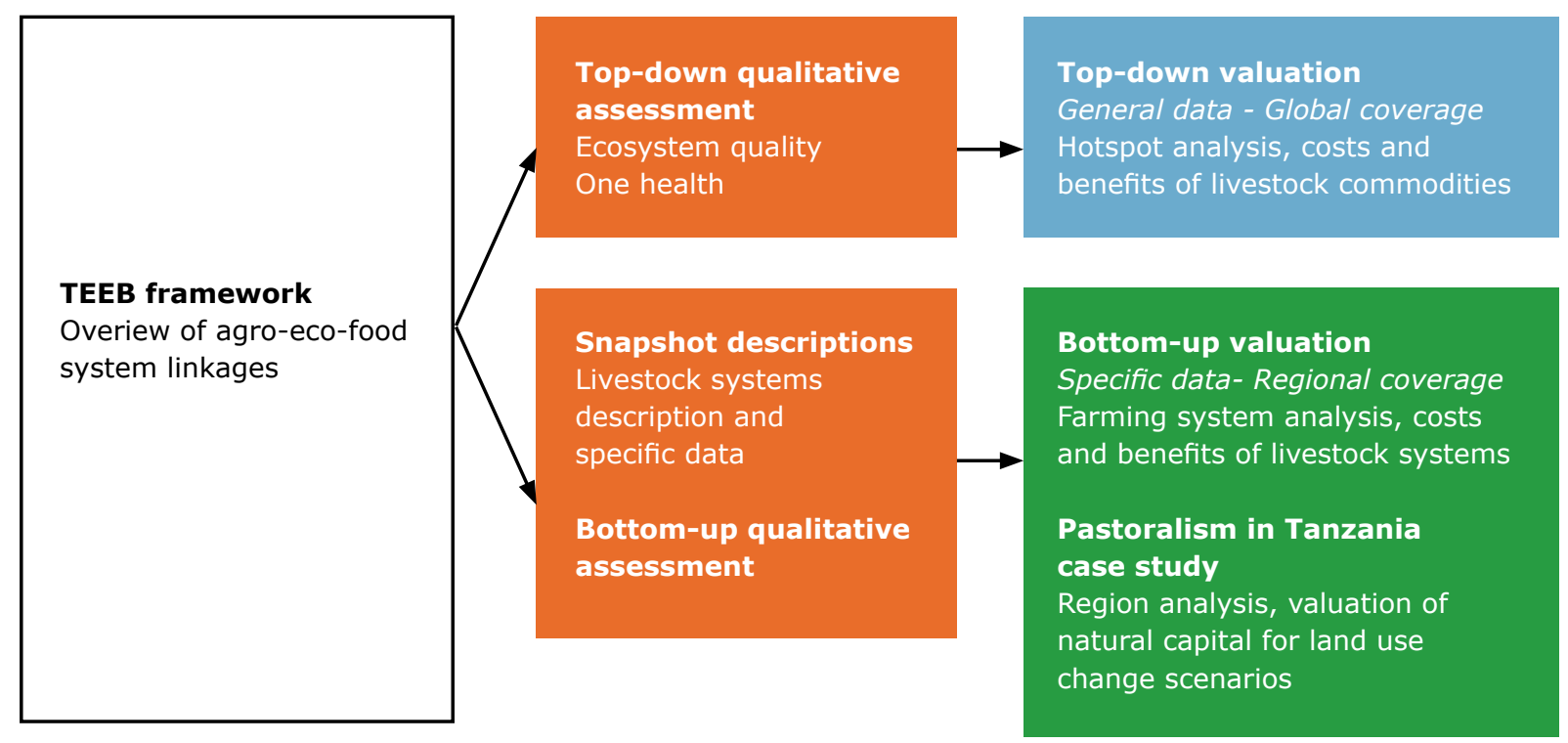

Figure 2.1 Overview of methodologies used to assess the impact of livestock production systems on socio-economic systems and ecosystems. We used the TEEB framework developed in 2014 which has be further developed in the meantime as TEEBAgriFood2015 framework.

As figure 2.1 shows, the valuation of costs and benefits derived from livestock can be approached in two ways. The top-down approach is a high-level analysis that identifies key geographical hotspots and material natural capital impacts, by building on Trucost's Environmentally Extended Input Output (EEIO) model and by using country-specific and/or global data (Trucost, 2016). The result of this analysis is a valuation for the production of each commodity at a country level, with no differentiation between farming systems. This type of analysis also makes it possible to determine the impact of livestock sectors worldwide. In this sense, a top-down approach can be informative for decision-making with a large geographical scope. The bottom-up approach goes into more detail. As a more detailed analysis, a set of livestock production systems for poultry, beef and dairy has been selected and described. These are called snapshots. Data are collected and used in the analysis to monetize the economic, social and environmental values and impacts of the different livestock production systems. A bottom-up approach can be the foundation for decision-making within a specific geographical scope.

By combining both analytical approaches, policy-makers can get an understanding of the externalities associated with livestock systems at a global level, and at the same time gain deeper insight in particular areas of interest. The top-down approach methodology is described in section 2.3 and the bottom-up approach methodology in section 2.4. The rationale for the selection of the snapshots is described in section 2.4.7. Furthermore, a comparison between the top-down and the bottom-up approach is made in section 2.5 . 


\subsection{Scope overview}

This study provides insights into the relationships between different livestock production systems, human systems, ecosystems and biodiversity in different countries. In order to do this, we map, visualize and valorize the use of natural capital inputs, and assess the negative and positive externalities ${ }^{4}$ of livestock production systems.

Figure 2.2 presents the relation between the scope of this study and the TEEB framework. The framework shows the sub-systems (human, livestock, ecosystem and atmosphere) and how they are linked together.

a On a global scale: A top-down approach that 1) briefly describes qualitatively and also values a selection of benefits provided by livestock, 2) values a wide set of impacts using an input-output model and natural capital valuations, obtaining the natural capital costs for different livestock commodities (greenhouse gas emissions, air pollutants, water consumption, water pollutants, soil pollutants and land-use change), 3) reviews qualitatively the interactions between livestock and biodiversity, and 4) reviews qualitatively the interactions between animal health and human health.

b On a regional scale: A bottom-up assessment of ten livestock systems from different regions and with different levels of intensity, with three levels of analysis. 1) Monetary valuation of greenhouse gas emissions, water pollution and dependency on blue water for all selected livestock production systems, 2) a quantitative assessment of other linkages where the conceptual model is known and quantitative information is available, and 3) a qualitative review of the issues where a conceptual model is known but quantitative information is lacking.

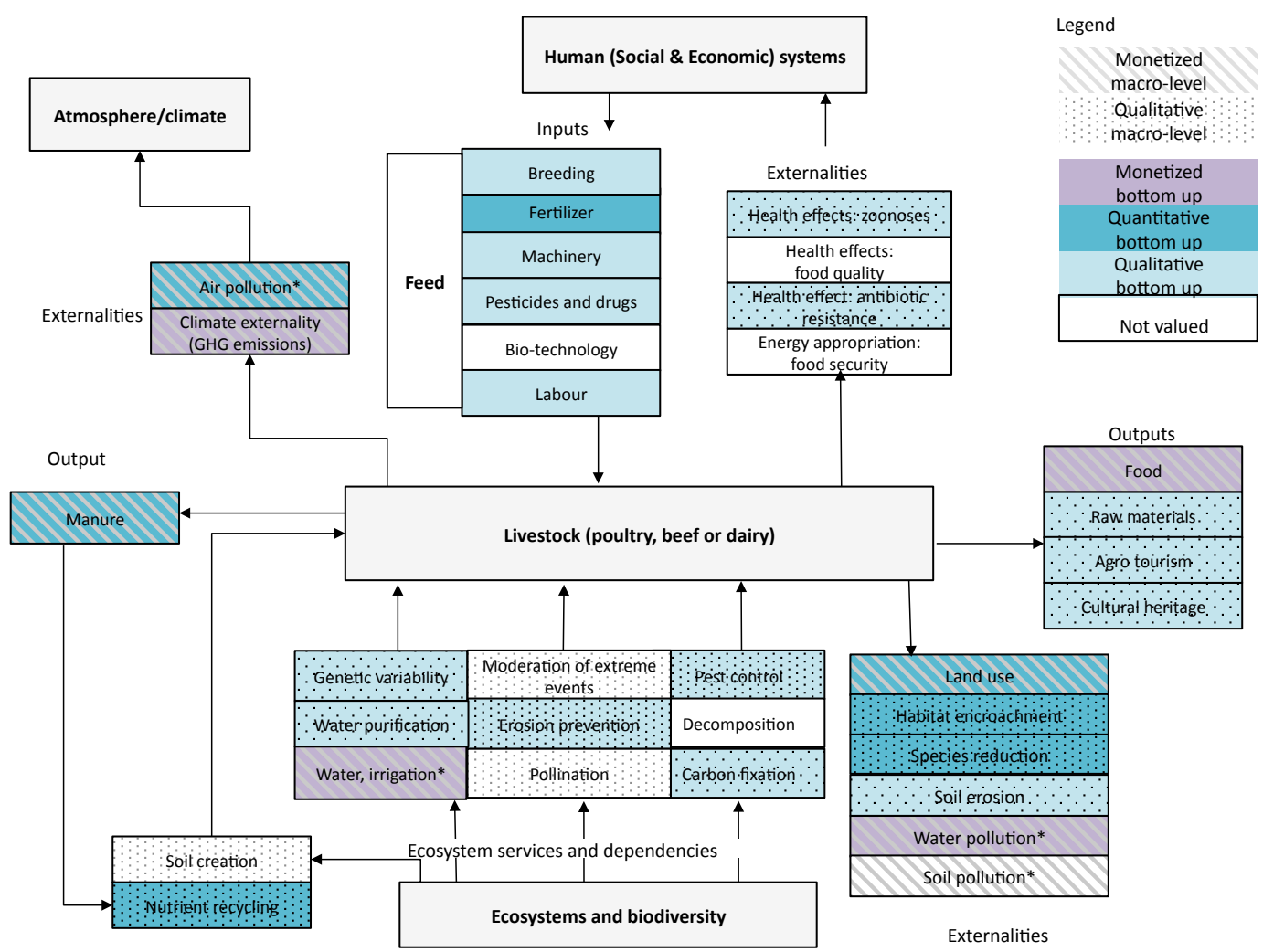

* Negative externalities valuation includes monetization of Health effects in the top down assessment

Figure 2.2 Scope of the assessment (adapted from Hussain and Miller, 2014)

Using the terminology specified in the TEEB AgFood Valuation Framework (as presented in chapter 3 of TEEB, 2015), these dimensions represent invisible flows within the Eco-agri-food complex. In the specific, negative and positive externalities are invisible flows going from agricultural systems to both ecosystems and the human system, while certain natural capital inputs or dependencies (such as blue water dependency) are invisible flows going from ecosystems to agricultural systems. Please note that, alongside invisible flows, visible flows were also analysed, such as food and raw materials. Visible flows are those normally accounted for in systems of national accounts and business accounts. 
Furthermore an in-depth case study looks at natural capital-human systems linkages for one of the selected livestock production systems (pastoralism in Tanzania) in a holistic manner and is not represented in figure 2.2. This analysis quantifies many dependencies on ecosystem services simultaneously and looks at local externalities using a time-explicit model. The in-depth case study is an example of how a detailed bottom-up valuation can show the invisible value of natural capital to the human economy in a given region.

Table 2.1 provides a more concise description of the scope of the overall study, split by top-down and bottom-up approaches, and how each of the categories has been analysed (qualitative, quantitative and monetized).

Table 2.1 Scope of the assessment for the top-down and bottom-up by type of analysis

\begin{tabular}{|c|c|c|c|c|c|}
\hline & Not valued & \multicolumn{2}{|c|}{ Qualitative } & Quantitative & Monetized \\
\hline Top-down & $\begin{array}{l}\text { - Food quality } \\
\text { - Food security } \\
\text { - Breeding } \\
\text { - Fertilizer } \\
\text { - Machinery } \\
\text { - Pesticides and } \\
\text { drugs } \\
\text { - Bio-technology } \\
\text { - Labour } \\
\text { - Decomposition }\end{array}$ & $\begin{array}{l}\text { - Raw materials }{ }^{1} \\
\text { - Agro-tourism }{ }^{1} \\
\text { - } \text { Cultural } \\
\text { heritage1 } \\
\text { - Zoonosis } \\
\text { - Antibiotic } \\
\text { resistance } \\
\text { - Genetic } \\
\text { variability }{ }^{1} \\
\text { - } \text { Water } \\
\text { purification }{ }^{1} \\
\text { - } \text { Moderation } \\
\text { of extreme } \\
\text { events }{ }^{1}\end{array}$ & 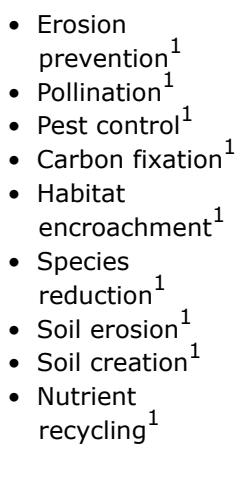 & & $\begin{array}{l}\text { - Food }{ }^{1} \\
\text { - Manure } \\
\text { - Water irrigation } \\
\text { - Land use } \\
\text { - Water pollution } \\
\text { - Soil pollution } \\
\text { - Pollution } \\
\text { - (air pollutants) } \\
\text { - Climate } \\
\text { (GH Gemissions) }\end{array}$ \\
\hline Bottom-up & $\begin{array}{l}\text { - Food security } \\
\text { - Biotechnology } \\
\text { - Moderation of } \\
\text { extreme events } \\
\text { - Pollination } \\
\text { - Soil creation } \\
\text { - Decomposition }\end{array}$ & $\begin{array}{l}\text { - Raw materials } \\
\text { - Agro-tourism } \\
\text { - Health effects } \\
\text { food } \\
\text { - Zoonosis } \\
\text { - Antibiotic } \\
\text { resistance } \\
\text { - Cultural heritage } \\
\text { - Breeding } \\
\text { - Machinery }\end{array}$ & $\begin{array}{l}\text { - Pesticides and } \\
\text { drugs } \\
\text { - Labour } \\
\text { - Genetic } \\
\text { variability } \\
\text { - Water } \\
\text { purification } \\
\text { - Erosion } \\
\text { prevention } \\
\text { - Pest control } \\
\text { - Carbon } \\
\text { - Sequestration } \\
\text { - Soil erosion }\end{array}$ & $\begin{array}{l}\text { - Fertilizer (as } \\
\text { part of nutrient } \\
\text { balance) } \\
\text { - Manure } \\
\text { - Nutrient } \\
\text { recycling } \\
\text { - Land use } \\
\text { - Species } \\
\text { reduction } \\
\text { - Habitat } \\
\text { encroachment }\end{array}$ & $\begin{array}{l}\text { - Food } \\
\text { - Water irrigation } \\
\text { - Water pollution } \\
\text { - Climate } \\
\text { (GH Gemissions) }\end{array}$ \\
\hline
\end{tabular}

1 Analysis limited to capturing the benefits at a high level (not at a country level and/or for all producing countries).

Finally, developing qualitative and quantitative indicators is often complicated because specific knowledge or data are lacking.

In the case of the bottom-up approach, to compare the different systems, similar basic data are needed, which are not always available. This problem is solved to a great extent by making use of the basic data and assumptions of the GLEAM model of the Food and Agriculture Organization of the United Nations (FAO) (MacLeod et al., 2013; Opio et al., 2013). Figure 2.2 depicts the fields which could not be quantitatively or qualitatively evaluated in this study.

In the case of the top-down approach, Trucost's EEIO model was used to quantify impacts on natural capital (Trucost, 2016). This model is built through a compilation of a wide range of data sources, such as life-cycle assessment studies, international databases with global coverage or company disclosures amongst others. 
Some aspects were only described qualitatively in the top-down assessment, in the bottom-up assessment for the ten snapshots, or in both, as shown in figure 2.2 and table 2.1. This is a case of many supporting, regulating and cultural ecosystem services ${ }^{5}$ provided by livestock systems, but also inputs for livestock production and health effects inherent to livestock systems.

\subsection{Top-down approach}

As mentioned previously, different elements that express the relationship between livestock systems, human systems, and ecosystems and biodiversity were analysed from a top-down perspective. Section 2.3.1 describes the methodology used to identify those relationships, with particular focus on impacts from livestock systems on ecosystems and human health due to environmental drivers (resource use and pollution) which are translated into costs; and on the different benefits provided by livestock in terms of ecosystem services. Section 2.3.2 focuses on the effects of livestock systems on biodiversity. Section 2.3.3 provides the approach used to determine the effects of livestock systems on human health, due to the consumption of livestock products.

\subsubsection{Top-down valuation}

\subsubsection{Methodological framework of the top-down approach}

\section{Natural capital costs}

The assessment in monetary terms of the impacts on natural capital by livestock systems resulting from resource use and pollutant emissions is expressed by the term 'natural capital costs'. Trucost has developed an approach that quantifies natural capital impacts in physical terms (cubic metres of water consumption, tonnes of emissions and hectares of land converted), and then converts the results into monetary terms (2015 US dollars). Valuing impacts on natural capital using a single metric makes it possible to identify hotspots and prioritize impact reduction efforts. The following sections describe the methods applied for the quantification and valuation (or monetization) of natural capital impacts. The natural capital costs included in this assessment are not captured by market forces, and are therefore considered negative externalities or invisible costs.

\section{Quantification}

Trucost's Environmentally Extended Input Output (EEIO) model was used for the top-down approach (Trucost, 2016). This model quantifies natural capital impacts at the farm level (direct model) and through its upstream supply chain ${ }^{6}$ (indirect model). This makes it possible to analyse impacts split by stage in the value chain, therefore providing visibility of supply chain impacts which are normally hidden. The assessment of direct natural capital impacts was as country-specific as possible, and the assessment of the supply chain impacts was based on global average factors. While livestock farm production is very location specific, supply chain activities involve sourcing inputs from different locations across the world. However please note that the economic interaction between sectors is constructed from supply and use tables published by the United States Department of Commerce, Bureau of Economic Analysis (BEA, 2015). The inter-sector relationships of the US economy were assumed to be representative of other countries globally.

\section{Valuation}

Valuation is the process of transforming physical quantities into monetary values using environmental valuation techniques. This step enables the quantification in monetary terms of the damage caused by pollution or natural resource extraction. The valuation framework used is based on an integrated biophysical and economic model, which follows a methodology proposed by Keeler et al. (2012). The biophysical model includes identifying the endpoint (for example, human population) and the change in

5 Ecosystem services are 'the direct and indirect contributions of ecosystems to human well-being' (de Groot et al., 2012).

6 Upstream supply chain includes business activities that supply goods and services to farms, such as feed for animals, fertilizers or antibiotics. 
valued attribute (for example, decreased human life expectancy) as a result of a change in physical conditions (such as an increase in the concentration of a pollutant in the atmosphere). The economic model involves identifying the valuation approach to assess the change in valued attribute (for example, willingness to pay to increase life expectancy). In this sense, the valuations reflect the damage on different endpoints: the damage to ecosystems and/or the damage to human health. For more information refer to Trucost (2016).

A top-down approach was used for the valuation exercise. This approach consists of creating a global valuation function that can be applied to specific locations. Benefit transfer, or value transfer, is an underlying principle of this approach. According to Brander (2013), 'value transfer is the procedure of estimating the value of an ecosystem service of current policy interest (at a "policy site") by assigning an existing valuation estimate for a similar ecosystem elsewhere (at a "study site")'. Value transfer techniques were applied to create country-specific valuations. Similar to the quantification phase, the valuation of direct natural capital impacts was as country specific as possible, and the valuation of the supply chain was based on global average factors.

Table 2.2 shows the global average natural capital valuation coefficients for each impact covered in the analysis, providing insight on the magnitude of the different impacts. Once the valuation coefficients were obtained per country, global average coefficients were determined by calculating a weighted average by purchasing power parity GDP using World Bank data (World Bank, 2015b). This was done for all the natural capital impacts except for the GHG emissions. The reason is that a rise in temperature in the atmosphere is expected to have a global impact, independent of location, and thus the valuation coefficient for GHG emissions is inherently global. Table 2.3 provides the range in country valuation coefficients for each impact, except for GHG emissions. The variation amongst countries for the valuation coefficients depends on different parameters. For example, in the case of air pollutants population density drives the change in the valuation coefficients; while for water consumption water scarcity and access to water - amongst other parameters - drive the change in the coefficients. More than 190 countries were included in the analysis with highly variable population densities, and consequently, high variability in the valuation coefficients for air pollution. For example, in the case of air pollutants, Singapore - with a valuation coefficient of 123,524 US\$/tonne for NOX- has a population density of approximately 4,000 times higher than Mongolia - with 29 US\$/tonne for NOX.

\section{Table 2.2 Global monetary valuation coefficients for natural capital impacts monetized in the analysis (in 2015 US\$ per unit)}

\begin{tabular}{|c|c|c|c|c|c|c|c|c|}
\hline \multicolumn{3}{|c|}{ GHG emissions ${ }^{7}$ (US\$/tonne) } & \multicolumn{5}{|c|}{ Air pollutants (US\$/tonne) } & \multirow{2}{*}{$\begin{array}{l}\text { Water consumption } \\
\text { (US\$/thousand } \mathrm{m}^{3} \text { ) }\end{array}$} \\
\hline $\mathrm{CO}_{2}$ & $\mathrm{CH}_{4}$ & $\mathbf{N}_{\mathbf{2}} \mathbf{O}$ & $\mathbf{N H}_{3}$ & $\mathrm{SO}_{2}$ & $\mathrm{NO}_{x}$ & vocs & PM10 & \\
\hline 128 & 3,200 & 38,148 & 4,390 & 2,730 & 3,051 & 6,210 & 13,918 & 45 \\
\hline \multicolumn{3}{|c|}{ Water pollutants (US\$/tonne) ${ }^{8}$} & \multicolumn{5}{|c|}{ Soil pollutants (US\$/tonne) ${ }^{9}$} & $\begin{array}{l}\text { Land use change } \\
\text { (US\$/ha) }\end{array}$ \\
\hline \multicolumn{3}{|c|}{11,552} & \multicolumn{5}{|c|}{16,520} & 1,164 \\
\hline
\end{tabular}

Source: Own calculation, Trucost (2016). Please see Trucost (2016) for sources and methods used.

7 Social cost of carbon, using the 95th percentile estimate for a $3 \%$ discount rate (USIAWG, 2013).

8 Average value for nitrogen, nitrate, phosphate and phosphorous.

9 Average value for 65 pesticides.

10 Land-use values are determined considering ecosystem services provided by different types of ecosystems specific to each country. 


\section{Table 2.3 Range for the monetary valuation coefficients for natural capital impacts mo- netized in the analysis (in 2015 US\$ per unit)}

\begin{tabular}{|c|c|c|c|c|c|c|c|c|}
\hline \multicolumn{3}{|c|}{ GHG emissions (US\$/tonne) } & \multicolumn{5}{|c|}{ Air pollutants (US\$/tonne) } & \multirow{2}{*}{$\begin{array}{l}\text { Water consumption } \\
\text { (US\$/thousand } \mathrm{m}^{3} \text { ) }\end{array}$} \\
\hline $\mathrm{CO}_{2}$ & $\mathrm{CH}_{4}$ & $\mathbf{N}_{\mathbf{2}} \mathbf{O}$ & $\mathrm{NH}_{3}$ & $\mathrm{SO}_{2}$ & $\mathrm{NO}_{\mathbf{x}}$ & vocs & PM10 & \\
\hline n.a. & n.a. & n.a. & $42-177,710$ & $26-110,527$ & $29-123,524$ & 893- 9,171 & $133-563,444$ & $6-1,175$ \\
\hline \multicolumn{3}{|c|}{ Water pollutants (US\$/tonne) } & \multicolumn{5}{|c|}{ Soil pollutants (US\$/tonne) } & $\begin{array}{l}\text { Land use change } \\
\text { (Us\$/ha) }\end{array}$ \\
\hline \multicolumn{3}{|c|}{$2,299-52,136$} & \multicolumn{5}{|c|}{$3,043-34,812$} & $22-7,127$ \\
\hline
\end{tabular}

Source: Own calculation, Trucost (2016).

A more detailed description of Trucost's EEIO model and the different valuation methodologies is described in Trucost (2016).

\section{Natural capital benefits}

Livestock systems produce a range of potential benefits in terms of ecosystem services, some of which are internalized in the market (visible benefits such as food), and some of which are not (invisible benefits or positive externalities such as pest control). This implies that only part of the benefits provided by livestock is visible to society and to the economy, with a wide range remaining invisible for decision-making.

The most obvious benefits of livestock systems relate to the provision of food and manure, which have been partially assessed in this analysis in a quantitative manner. Food provisioning services were valued based on the local retail price of beef and chicken meat, and milk, available on the market in selected countries. Manure production for use as fertilizer was valued based on the retail cost of chemical fertilizers required to deliver an equivalent quantity of nitrogen, phosphorus and potassium as is contained in beef, dairy and poultry manure. Other positive benefits arising from livestock production systems were assessed qualitatively based on a limited review of relevant published literature. This includes an assessment of the positive effects of livestock systems on provisioning, regulation, supporting and cultural ecosystem services.

\subsubsection{Scope and objectives of the top-down approach}

The top-down approach was developed for beef, dairy milk and poultry meat production. The analysis provides an indication of some benefits provided by livestock sectors and it also determines the costs associated with livestock sectors.

The top-down approach:

- Summarizes important benefits provided by livestock systems in terms of ecosystem services;

- Compares the costs on natural capital in both absolute terms (expressed in million US\$) and in relative terms (expressed in US $\$ / \mathrm{kg}$ protein produced) for the selected three livestock products (beef, dairy and poultry meat);

- Identifies which are the most material natural capital costs that have been considered in the study and which are the geographical hotspots worldwide;

- Assesses the contribution to the natural capital cost of farming operations versus supply chain operations (upstream);

- Provides contextualization for the selected snapshots.

Natural capital costs are calculated considering the impacts from the production inputs to the farm gate. Those impacts have been split by supply chain impacts (upstream) and operational impacts (farming), and cover six categories: GHG emissions, air pollutants, water consumption, water pollutants (from fertilizer application), soil pollutants (from pesticide application) and land-use change. Total natural capital costs of the selected livestock sectors worldwide were determined considering all producing countries for each of the sectors (over 190 producing countries). FAO data was used to identify producing 
countries and respective production quantities (FAO, 2015a). Downstream supply chain impacts, from the farm gate to the end consumer, are not included in the scope of the analysis. Due to the high level of coverage, a differentiation between farming systems has not been included in the top-down approach and has been captured as part of the analysis conducted in the different snapshots. In order to identify the commodity that provides the greatest amount of protein with the least environmental impact, natural capital costs were normalized by the protein content of each commodity. Average protein contents were considered for poultry meat, beef and dairy milk. In particular, $19 \%$ was used for poultry meat and beef (Lawrie and Ledward, 2006), and 3.3\% for dairy milk (de Vries and de Boer, 2010). Natural capital intensities were determined at a country level by dividing the country-specific natural capital cost (operational and supply chain costs) by the amount of protein produced per country for each livestock commodity.

In the case of benefits, the quantitative analysis was limited to the valuation of the provisioning of food and manure as organic fertilizer. These provisioning services were valued on the basis of the retail market price of the food produced, or an equivalent quantity of chemical fertilizer in the case of manure production. This approach is consistent with TEEB's recommendations (Pascual et al., 2010), which suggest market price-based approaches as a valid method of valuing provisioning services. Other benefits were analysed qualitatively based on a limited review of the available literature.

Table 2.4 outlines the scope of the valuation for each cost and benefit associated with livestock production included in the analysis (monetized only, through the use of valuations), while table 2.5 highlights the key inputs, outputs, costs and benefits provided by animal husbandry systems that have been included in the top-down approach (monetized or assessed qualitatively). Further benefits provided by livestock that have been assessed qualitatively, such as draught power or weed control, are described in section 3.1.2.

Table 2.4 Natural capital costs and benefits that have been given a monetary value in this analysis

Natural capital costs $\quad$ Scope of the valuation

GHGs (from energy and non-energy sources)

Multitude of impacts, including but not limited to, changes in net agricultural productivity, human health and property damages from increased flood risk. The GHGs considered in this analysis include carbon dioxide, methane and nitrous oxide. The social cost of carbon, in 2015 USD, used in this study is US $\$ 128$ per tonne $\mathrm{CO}_{2}$ (USIAWG, 2013). ${ }^{11}$

Air Pollutants

The impacts of air pollutants on human health are captured in this valuation. This includes impacts from the emission of SOX, $\mathrm{NO}_{X^{\prime}}$ PM10, VOCs and ammonia from sources such as fuel use, fertilizer application, pesticide application and manure application.

Water pollutants (from fertilizer application) Eutrophication impacts on ecosystems and human health, associated with algal blooms and drinking water quality. This valuation includes the impacts from the emission of nitrogen, nitrates, phosphates and phosphorus.

Soil pollutants (from pesticide application) Soil pollutants have toxic impacts on human health and ecosystems. This valuation includes the impacts of over 60 pollutants, including pesticides such as atrazine, herbicides such as Diuron and fungicides such as Folpet.

11 A social cost represents the cost to society as a whole resulting from an action, in this instance, the emission of carbon. According to USIAWG (2013), 'the Social Cost of Carbon is an estimate of the monetized damages associated with an incremental increase in carbon emissions in a given year'.

12 In the case of land use, in the top-down approach all ecosystem services were assumed to be lost due to farming practices, while this could be refined with future research as livestock does not necessarily imply the loss of all ecosystem services, and in some instances it could enhance the provision of certain ecosystem services. As an example, chapter 5 describes a case study in Tanzania which shows that the provision of certain ecosystem services can be encouraged through pastoralism systems. 
Water consumption

Water consumption valuation includes the impacts on human health and ecosystems. The unit of measurement for human health impacts is disability adjusted life years (DALYs) and affected net primary productivity (NPP) in the case of ecosystem damage.

Land-use change

This values the ecosystem services lost from the conversion of natural ecosystems to agricultural land. Trucost has calculated the country-specific distribution of several global ecosystems, as well as the global average value for the ecosystem services each one provides. This allows Trucost to calculate the average ecosystem value, per hectare, in each country. ${ }^{12}$

Natural capital benefit Scope of the valuation

Food provisioning

Provision of poultry meat, beef and dairy milk. The valuation captures the benefits that the provision of those commodities represent to society, as market prices are used.

Manure provisioning

Provision of nutrients to the soil. The valuation captures the benefits that the application of manure to soil represents to society, as market prices are used.

Table 2.5 Key inputs, outputs, costs and benefits of animal husbandry systems included in the top-down approach

\begin{tabular}{|c|c|c|c|c|}
\hline Input & Output & $\begin{array}{l}\text { Costs }(-) \text { or } \\
\text { benefits }(+)\end{array}$ & $\begin{array}{l}\text { Ecosystem service } \\
\text { influenced }\end{array}$ & $\begin{array}{l}\text { Type of } \\
\text { assessment }\end{array}$ \\
\hline Water use & N/A & Water depletion (-) & Diverse & Monetized \\
\hline Energy use & $\mathrm{N} / \mathrm{A}$ & GHG emissions (-) & Diverse & Monetized \\
\hline Energy use & N/A & Air pollution (-) & $\begin{array}{l}\text { Regulating } \\
\text { (air quality) }\end{array}$ & Monetized \\
\hline Fertilizer application & N/A & Water pollution (-) & Diverse & Monetized \\
\hline Pesticide application & N/A & Soil pollution (-) & Diverse & Monetized \\
\hline Land use & N/A & Land-use change (-) & $\begin{array}{l}\text { Cultural, Regulating and } \\
\text { Provisioning }\end{array}$ & Monetized \\
\hline $\mathrm{N} / \mathrm{A}$ & $\begin{array}{l}\text { Food (dairy milk, beef } \\
\text { and poultry meat) }\end{array}$ & Provision of food $(+)$ & $\begin{array}{l}\text { Provisioning } \\
\text { (food) }\end{array}$ & Monetized $^{14}$ \\
\hline $\mathrm{N} / \mathrm{A}$ & $\begin{array}{l}\text { Raw materials (animal } \\
\text { manure) }\end{array}$ & $\begin{array}{l}\text { Provision of raw } \\
\text { materials }(+)\end{array}$ & Provisioning (manure) & Monetized $^{15}$ \\
\hline $\mathrm{N} / \mathrm{A}$ & $\begin{array}{l}\text { Eco/Agro-tourism, } \\
\text { amongst others }\end{array}$ & Recreation $(+)$ & $\begin{array}{l}\text { Cultural } \\
\text { (recreation) }\end{array}$ & Qualitative \\
\hline N/A & $\begin{array}{l}\text { Soil carbon } \\
\text { sequestration amongst } \\
\text { others }\end{array}$ & Climate regulation $(+)$ & $\begin{array}{l}\text { Regulating } \\
\text { (climate regulation) }\end{array}$ & Qualitative \\
\hline
\end{tabular}

\subsubsection{Key data sources of the top-down approach}

In the top-down analysis, natural capital costs were determined considering the producing countries for each sector. As mentioned previously, FAO data was used to identify producing countries and associated production quantities worldwide (FAO, 2015a). A wide range of consolidated data sources were used both in the EEIO model (such as life-cycle assessment studies or company disclosures) and for each valuation

\footnotetext{
13 For more information, see Trucost (2016).

14 Assessed quantitatively for a sample of countries: USA, Brazil and China.

15 Assessed quantitatively for the USA.
} 
methodology (such as environmental economics publications and internationally recognized databases). The detailed data sources used in the top-down approach, for both the valuation methodologies and Trucost's EEIO model, are described in detail in a separate report (Trucost, 2016).

In order to value the benefits provided by livestock, data from the Chinese Ministry of Agriculture (MOA, 2015), USDA (2015), and Instituto de Economia Agrícola (2015) was used to determine the retail price of livestock commodities. The benefit of manure provisioning was valued based on the retail price of the chemical fertilizers required to replace the nutrient content of the manure. In order to do that, the nutrient content of beef, dairy and poultry manure was estimated based on Brown (2013), and the retail price of various chemical nitrogen, phosphorus and potassium fertilizers was sourced from the USDA (2013) and inflated to 2015 prices based on the World Bank (2015b).

\subsubsection{Limitations of the top-down approach}

There are inherent limitations to the use of a top-down approach. This part of the study relies on national output data from which natural capital impacts are derived at a country level. This implies that in different instances country averages were used. For the purpose of a high-level assessment at a country level, the use of country averages can be considered an appropriate technique. In addition, the top-down approach does not attempt to capture intra-national differences in impacts, or differences between specific technologies and farming practices. Trucost recognizes the existence of intra-national differences and the fact that local conditions are relevant when granular analysis are undertaken. However, calculating all impacts from a bottom-up perspective covering all producer countries worldwide would not be feasible from a resources and timing perspective. These results are therefore strengthened by the bottom-up analysis and the use of primary data for identified key locations.

General limitations regarding the natural capital valuations used in the top-down approach are described below in table 2.6. Those limitations are related to aspects such as the aggregation of data, the exclusion of specific costs and benefits, or the use of value-transfer techniques. Specific limitations for the different valuation methodologies, such as water consumption and eutrophication, appear in Trucost (2016).

Table 2.6 Summary of limitations for the valuations applied in the top-down approach

\begin{tabular}{ll} 
LIMITATION & EXPLANATION \\
Aggregation of data & $\begin{array}{l}\text { In some cases, components of valuations which represent impacts on different } \\
\text { receptors, such as human populations, are aggregated and use different valuation } \\
\text { techniques. The individual components of valuations may or may not be directly } \\
\text { comparable, but the methodology applied is consistent across the different impact } \\
\text { categories and to each unique receptor. }\end{array}$ \\
\hline Exclusions & $\begin{array}{l}\text { Some natural capital costs have been excluded on the basis of materiality or data } \\
\text { availability. Please see the relevant methodology sections in Trucost (2016) for } \\
\text { further information. In addition, benefits are covered only briefly and mainly assessed } \\
\text { qualitatively. }\end{array}$ \\
\hline Scope & $\begin{array}{l}\text { The assessment is limited to impacts from the production of inputs to the farm gate. } \\
\text { Impacts associated with further post-farm gate processing and consumption are not } \\
\text { assessed. }\end{array}$ \\
\hline Vtatic & Valuations are adjusted using inflation rates applied at a specific point in time. \\
\hline Value transfer & $\begin{array}{l}\text { Value transfer was used to assess the impacts on ecosystems and human health. Value } \\
\text { transfer techniques inherently imply a degree of uncertainty when compared to primary } \\
\text { valuation techniques (Brander, 2013). }\end{array}$ \\
\hline
\end{tabular}

16 In the case of benefits, the provision of manure was captured only for the USA to give an indication of this key service derived from livestock. The USA was selected as an example as it is a key contributor to the natural capital cost worldwide for the three selected commodities and data availability is high for this country compared to other key contributors. In the case of costs, water pollution and soil pollution were only captured for the production of feed within the supply chain, therefore outside the farm. Thus, water pollution from manure application on livestock farms was not part of the analysis and is included in the bottom-up chapter. 


\subsubsection{Biodiversity}

Relationships between livestock production systems and biodiversity were included using a literature review. The included studies looked at impacts through habitat loss, grazing pressure, pollution, feed production and greenhouse gas emission, but also included some positive relationships as a result of the protective effects of livestock grazing. Given the time limitations and the broad scope of the topic it was not possible to perform a full systematic review of the relations between livestock production and biodiversity.

\subsubsection{Animal and human health}

The assessments are based on literature research and indicators are qualitatively assessed.

\subsection{Bottom-up analyses}

The top-down approach is complemented by a bottom-up approach, which uses as much local data for the impact assessment and valuation as possible. The methodology and data sources for the bottom-up analyses are described in detail in the separate publication (True Price, 2016), and here we provide a brief summary of the methodological framework.

\subsubsection{Methodological framework for impact assessment and valuation}

The definition of natural capital follows the approach described in the System of Environmental Economic Accounting (SEEA) 2012 (UN/EU/FAO/IMF/OECD/World Bank, 2014a, 2014b, 2014c) and in particular the Experimental Ecosystem Accounting framework. With this approach natural capital assets can be identified which are 'the naturally occurring living and non-living components of the Earth, together constituting the biophysical environment, which may provide benefits to humanity' (UN/EU/FAO/IMF/OECD/World Bank, 2014a).

The valuation method builds upon the framework provided by UNEP's Inclusive Wealth Reports (UNEPIHDP and UNEP, 2014, 2012), the starting point of which is the total wealth of a region. The value of a natural capital asset is determined by its contribution to inclusive wealth, representing the present and future benefits of an asset to people. When a specific geographical area is selected, the value of natural capital can be further differentiated between internal natural capital value, which represents the benefits to all local stakeholders within a region, and external natural capital value, which represents the benefits to all stakeholders outside of the region.

Negative externalities are valued as natural capital costs because they damage ecosystems services (i.e. from clean water supply to climate regulation) and reduce the benefits they provide to humans. In addition to negative externalities, natural capital dependencies can also be valued. The dependency of a good on a natural capital asset is the contribution of that asset to the value of a good in terms of inclusive wealth.

To determine the natural capital impact of a choice, the change in the value of natural capital assets is estimated. The choice for inclusive wealth means that the valuations assume that the decision-maker aims to maximize inclusive wealth, as its primary goal or as one of its goals.

The methodological framework developed for the bottom-up analysis of natural capital is derived according to the True Price Principles for Impact Measurement and Valuation (True Price, 2016). The underlying perspective of the quantitative valuation is that measuring and valuing natural capital can be used to inform decisions. The starting point is a decision-maker (such as a policy-maker or a consumer) who faces a choice and each choice alternative has a certain impact on the state of the world. To make an informed decision three steps need to be taken:

1 The decision problem, and in particular the choice set of the decision-maker, is identified;

2 The impact of the relevant choice alternatives on the state of the world is measured by characterizing the system the decision-maker impacts and the consequences of each choice;

3 The impact of each choice is valued, providing a measure of the desirability of each choice alternative for the decision-maker. 
The bottom-up assessment is divided in two parts: a valuation of animal husbandry snapshots' externalities and dependencies on natural capital and a case study on the value of natural capital assets in the Maasai Steppe in relation to land conversion.

\subsubsection{Bottom-up quantitative impact assessment and valuation of snapshots}

The framework is primarily applied to value a few key impacts and dependencies:

1 It is determined which snapshots constitute possible substitutes for a policy-maker and therefore can be compared in terms of their natural capital impacts.

2 A quantitative environmental and economic supply chain model is made consisting of the farm and feed imports for each snapshot based on local data where possible. The natural capital impacts of producing poultry, beef or milk through greenhouse gas (GHG) emissions, water pollution and land use are calculated (unless they are immaterial/insignificant). In addition, the dependency of each product on blue water is calculated. The natural capital impacts and dependencies are valued (except for land use) based on local data wherever possible.

The main methodological aspects of each natural capital impact assessed in the bottom-up analysis are presented below, with a focus on valuation approach and granularity of data sources. Key data sources for the biophysical model of snapshots are presented in section 2.4.3. Data sources with an exhaustive explanation of the valuation methods can be found in a separate report (True Price, 2016).

- GHG quantification is based on the FAO Global Livestock Environmental Assessment Model GLEAM (Gerber et al., 2013) and valuation based on the IAWG social cost of carbon (USIAWG, 2013), consistently with the top-down valuation.

- Water pollution is quantified based on nutrient inputs to land according to the agronomic model of the farms in each snapshot. It is valued based on global monetary coefficients of the natural capital cost of eutrophication. Global coefficients are used because of lack of time and based on Weidema (2009). Water pollution occurring upstream in the supply chain is not included. This is because in most cases the largest share of feed is produced on farms. For the rest, the supply chains of the ten snapshots extend to more than 20 countries, and a bottom-up assessment of water pollution in all of them was not feasible within the scope of this study.

- Blue water dependency is quantified based on feed production data and valued based on the increase in marginal productivity resulting from inputs of blue water and the associated economic profit in each snapshot. Local data about yield and input cost from the countries where feed is produced were gathered through a literature research. The valuation approach was developed combining the imputation method (FAO, 2004) and the residual rent method (Thompson and Johnson, 2012). As opposed to water pollution, here both farms and supply chains were included, because only a share of the snapshots make use of feed produced in irrigated farms.

- Land occupation on farms is quantified based on feed intake per unit of product and the average land use of $1 \mathrm{~kg}$ of the animals' ration. Farm supply chains chains are also included in full, using country-average crop yields for purchased feed.

All impacts are monetized in 2015 US dollars. Other currencies are converted using purchasing power parity (PPP) to correct for exchange market distortion. Land use is not monetized, but a land use change model is provided for one of the livestock snapshots (see section 2.4.5 In-depth case study: Pastoralism in the Maasai Steppe, Tanzania).

\subsubsection{Data sources}

The following data was used for the assessment and comparison of the snapshots. Technical parameters regarding livestock production, inputs, crop yields and emissions, for example, are largely based on the Global Livestock Environmental Assessment Model GLEAM (MacLeod et al., 2013; Opio et al., 2013). For the snapshot descriptions, databases available at FAO were used (FAOstat). Data in GLEAM is based on FAOstat and other databases. References to the databases used can be found in the References section in this report and in the appendices of the reports by Opio et al. (2013) and MacLeod et al. (2013). In addition, the Tanzanian snapshot uses the World Bank's Living Standards Measurement Study-Integrated Surveys on Agriculture. This data is supplemented with information from the literature. In addition to the 
quantitative indicators, several indicators could be assessed only qualitatively on the basis of expert knowledge and (grey) literature.

\subsubsection{Mean species abundance of original species}

In our bottom-up analyses of the snapshots we include an assessment of biodiversity impacts based on the 'mean species abundance of original species' indicator (MSA), which is used in the GLOBIO3 modelling framework (see Alkemade et al., 2009). MSA is a relative indicator between 0 and 1 that relates population sizes of species occurring in a location to the population sizes of those species that would occur in an unaltered reference situation, which is often indicated as pre-industrial. Basically it is an indicator for the naturalness (i.e. the situation without human intervention) in a certain location. Doseresponse functions have been elaborated to relate different levels of anthropogenic pressures to the MSA (e.g. Alkemade et al., 2013, 2009; Arets et al., 2014). The indicator has been applied in a scenario analysis of a large number of global and regional biodiversity assessments (including Kok and Alkemade, 2014; ten Brink et al., 2010, 2007). Recently a targeted study has generated specific dose-response relations for rangelands with different intensities of grazing and management (Alkemade et al., 2013), which has been applied in a global assessment of trade-offs and synergies between grazing intensity and ecosystem services in rangelands (Petz et al., 2014a).

By multiplying the area affected by the MSA indicator for the pressures operating in that area, a quality-adjusted area can be assessed, which can be compared among different regions and/or scenarios. Here we estimated the biodiversity footprint based on land use (i.e. a quality-adjusted land occupation) based on the land occupation (ha per kg protein) as explained and quantified in section 4.3.4. The resulting indicator, MSA.ha (dimension ha), translates the affected area into an area that would lose $100 \%$ of its diversity.

\section{Land-use impacts on biodiversity}

The land-use impacts for the different snapshots were quantified in terms of MSA loss for the areas needed for grazing (pastures and rangelands) and croplands for feed production. For pastures and croplands the cause-effect relations in Alkemade et al. (2009) and Reidsma et al (2006) were used, while for rangelands the relations from Alkemade et al. (2013) were applied. The intensity of rangeland grazing in the Tanzanian pastoralist snapshot was retrieved from Petz et al. (2014a).

To allow for more differentiation in MSA impacts depending on the intensity of land use, we interpolated between the classes based on the snapshot descriptions and discussion within the research team. While this possibly does not provide the exact value of the actual impacts, it allows differentiating among the intensities of land use in different snapshots.

The method does not (currently) include recovery of biodiversity at local scales due to specific conservation management practices in agriculture, although there are a number of initiatives to implement such modifications for local assessments in the Netherlands (Reijnen et al., 2010) and Norway (Aslaksen et al., 2012a, 2012b). Within the scope of this study, however, it was not possible to take such adjustments into consideration.

\section{Climate-change impacts}

Emissions of greenhouse gases contribute to climate change. The degree of change depends on the type of GHG and the time horizon over which the impact is assessed. Subsequently climate change will have a global effect, not just a local one. To assess the impact of GHG emissions the following steps are followed:

1 Emissions in terms of $\mathrm{CO}_{2}$ eq. are considered on the basis of the information provided in the snapshots.

2 Temperature factors will be used to translate the contribution of $1 \mathrm{~kg}$ of $\mathrm{CO}_{2}$ to the increase of global mean temperature (GMT) for different time horizons (Hanafiah et al., 2012). These factors are

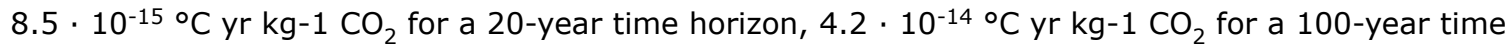

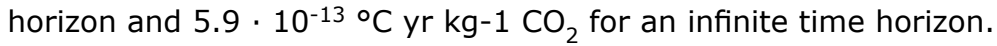

3 The dose-response function from GLOBIO3 determines the MSA effect of increasing GMT (figure 2.1 Arets et al., 2014).

4 The impact of GHG emissions is considered to affect the total global area of (semi) natural habitat. 
This area, based on the reference scenario in Kok en Alkemade (2014), was $9.06 \cdot 10^{7} \mathrm{~km}^{2}$. This translates to a loss of 0.0329MSA.ha per $\mathrm{Gg} \mathrm{CO}_{2}$ emissions for a 100 -year time horizon.

\subsubsection{In-depth case study: Pastoralism in the Maasai Steppe, Tanzania}

In addition, the framework is applied to value the impact of land conversion in the Maasai Steppe, an important region in Tanzania for livestock production:

1 The case is interesting to policy-makers as it is assumed that they have some policy options to influence the rate of land conversion from natural land to farmland;

2 The impact of land conversion on the ecosystem services provided in the region is estimated based on a model of the Maasai Steppe and the local economy supported by it; and

3 The value of natural capital to local stakeholders is estimated under various land conversion scenarios. In addition, the value of carbon stocks to global stakeholders is estimated.

This analysis focuses mainly on the internal natural capital value. An important part of the model is that the size of future benefits depends on the sustainability of production practices. To avoid double counting, the valuation scope only includes final ecosystem services (as opposed to intermediate), which are those services that create direct value for humans (see table 2.7).

\section{Table 2.7 Landscape level valuation factors}

\begin{tabular}{|c|c|c|c|}
\hline Category & Ecosystem benefits & Unit & Value $(*)$ \\
\hline \multirow[t]{5}{*}{ Crops and livestock } & Beef and cow milk (pastoralism) & $\$ /$ animal/year & 98 \\
\hline & Goat milk (pastoralism) & \$/animal/year & 9 \\
\hline & Livestock (farming, various animals) & \$/animal/year & 103 \\
\hline & Crops (maize and beans) & $\$ /$ ha/year & 220 \\
\hline & Animal skins and hides & \$/animal/year & 0,05 \\
\hline \multirow[t]{3}{*}{ Traded products } & Honey and beeswax & $\$ /$ harvesting household/year & 400 \\
\hline & Gum & $\$ /$ harvesting household/year & 105 \\
\hline & Medicinal plants & \$/inhabitant/year & 6 \\
\hline \multirow[t]{4}{*}{ Subsistence } & Wild foods & $\$ /$ inhabitant/year & 0,86 \\
\hline & Drinking water & $\$ /$ inhabitant/year & 25 \\
\hline & Fuelwood, poles, thatch, charcoal & \$/inhabitant/year & 22 \\
\hline & Tourism revenues & $\$ /$ visitor/year & 94 \\
\hline
\end{tabular}

${ }^{*}$ ) Values as expressed here are further attributed to ecosystem services by correcting for human inputs (such as labour or agricultural inputs) that are required for value creation. See True Price 2016, Part III for attribution methodology.

This is consistent with the general framework that puts the total wealth of a region central. Crops and agricultural products are also included, consistent with a natural capital accounting approach (UN/EU/ FAO/IMF/OECD/World Bank, 2014c). Intermediate ecosystem services, such as soil fertility or pollination are therefore included by valuating their indirect benefits (i.e. crops and livestock). 
An important characteristic of the approach followed in this study is that it distinguishes the contributions of ecosystems to value creation from the contributions of other inputs such as labour and agricultural inputs. This attribution approach, based on ratios between shadow prices of inputs, allows comparisons of the ecosystem services derived from natural ecosystems with those from agricultural and managed ones.

Finally, the value of ecosystem benefits is estimated using value transfer according to the guidelines by Brander (2013). In each step, the analysis uses as much local data as possible and otherwise uses data from comparable regions, such as other parts of Tanzania or the Maasai region in Kenya. This avoids the uncertainty related to the transfer of value from very different contexts. As this form of valuation is data intensive, the analysis is undertaken only for the Maasai Steppe in Tanzania.

The method and data sources used for this analysis are comprehensively illustrated in True Price (2016).

\subsubsection{Limitations}

The bottom-up impact assessment and valuation makes use of country-specific data and individually modelled farms. Although it offers a high level of detail, this approach also has some limitations.

- The scope of valuation is partial. Although the descriptions of the snapshots and the qualitative assessment do cover a broad range of natural capital-livestock linkages, the impacts that could be quantified and monetized are limited to a smaller set. Although this in no way influences the reliability of the results, it is important to keep in mind that other aspects (human health risk, for example, or soil degradation) should also be considered when drawing conclusions.

- The focus is on one type of benefit. Livestock is mainly kept for food provision, and therefore animal protein was chosen as the functional unit for this assessment. However, there are other benefits that humans derive from animal husbandry, which are overlooked if we limit our scope to the ratio between external costs and food output. Animal traction and the use of manure as fuel or as soil amendment could also be assessed monetarily from the bottom-up. The same holds for the quality of food produced, as contribution to human health could also be included in the assessment of invisible benefits. Including into the picture these other benefits, in addition to the production of animal protein, would result in a more complete assessment but introduce many methodological challenges, related to the choice of a functional unit and system boundaries.

- Comparability is limited. The bottom-up valuation quantitatively assesses and compares ten livestock snapshots. The results are expressed in the same unit ( $\$ / \mathrm{kg}$ of protein) and compared. However, the snapshots capture livestock systems in very different contexts and climates, with their own economic and ecological constraints, and the systems are not necessarily substitutes of each other. This implies that the environmental performance of snapshots cannot always be ranked or compared directly. Therefore, when the results are presented extra attention is given to comparison of snapshots that are to an extent producing substitutable products. Extending the valuation to a larger set of snapshots would make it easier to generalize the results.

- System boundaries differ. Because they rely on different models and the availability of regional data, system boundaries are not exactly the same for each natural capital aspect valued. For example, feed production is excluded for water pollution, and GHG emissions also include post-farm transport and processing. Land use and blue water dependency have the same system boundaries.

\subsubsection{Snapshot selection of livestock production systems}

As TEEB requested an analysis of livestock production systems, it is important to select relevant systems fulfilling the requirements set in the terms of reference and described in section 1.1. The selected systems we will analyse with a bottom-up analysis are called snapshots.

Within livestock production systems we selected:

a Beef systems. Beef systems are farms where large ruminants are kept for meat production only, and where no or little milk is used for own consumption, nor is it marketed. All emissions and natural costs are allocated to beef production only.

b Dairy systems. These are livestock production systems that focus mainly on the production of milk. In our study, dairy systems are farms where large ruminants are kept and where milk is produced for a market, providing a regular income to the farm, even when the milk is not the main component of the farm income and cattle also have a role as draught animals and as an asset (capital value of the 
cow). Dairy systems can be highly specialized, but also non-specialized, and mixed arable-livestock systems are considered as dairy in this study. In the dairy systems, the emissions and the natural costs are allocated to milk and meat. Beef is also produced in these systems if animals are culled.

c Poultry systems. Poultry systems can produce eggs and meat. In this study we focused on backyard systems that produce eggs and meat, and on (semi) specialized broiler systems which only produce chicken meat.

Both beef and dairy systems can be mixed systems, where the feed basis of cattle consists of fodder crops, crops residues and grass. But these can also be grassland-based systems, where the feed basis is grass and where a maximum of $10 \%$ of the feed comes from crop production systems. In some regions, the latter are also called pastoral systems. Pastoral farmers can travel (transhumance) and can be sedentary. The ruminant classification is based on the FAO publication by Seré and Steinfeld (1996), which is used in many livestock studies. The livestock system description has been extended to other animal types by Robinson et al. (2011).

The criteria to make a choice among possible snapshots (combination of livestock production systems and countries or regions) within countries are the following:

1 Global food pattern: pork is often not consumed in many places in the world. So pork has been excluded in this study.

2 Importance and representativeness of the livestock production system on a global scale. Wint and Robinson (2007) and Robinson et al.(2011) are used to identify the most important regions in the world and to characterize the livestock production systems for beef, milk and broilers (see also figure 1.1).

3 Expected increased demand for animal proteins: Livestock production systems of different intensities exist. For beef and dairy this ranges from pastoralist and low-input mixed systems to specialized, intensive production systems and for poultry from backyard to large-scale commercial production. These systems are based on Robinson et al. (2011) as well, which updates Seré and Steinfeld (1996).

4 TEEB asked us to include pastoralist livestock production systems in Tanzania so as to link with the wider TEEB portfolio of work, which includes a TEEB Tanzania Country Study.

5 Comparability:

a Can the different indicators for the assessment of each livestock production system be measured consistently (expectation about availability of data)?

b Systems or products are only partial substitutes (price development does not necessarily lead to product or production system replacement).

6 A range of agri-environmental zones have to be covered. Humid systems have different characteristics than systems in arid zones.

7 Data availability.

Given the above criteria, ten snapshots have been selected (see figure 2.3).

\begin{tabular}{llll} 
Species & $* *$ Extensive <- & 2. Indonesia & 3. Netherlands industrial broilers \\
Poultry & 1. Tanzania (backyard) & 5. India (pastoralist) & $\begin{array}{l}\text { 6. Brazil (grassland based with 3 } \\
\text { months in feedlots for fattening) }\end{array}$ \\
\hline Grassland-based beef & 4. Tanzania (pastoralist) & 8. India & $\begin{array}{l}\text { 9. The Netherlands } \\
\text { 10. Indonesia }\end{array}$ \\
\hline
\end{tabular}

** Extensive is defined as using no or low external inputs like feed, labor, antibiotics and intensive is defined as using relative high levels of inputs.

Figure 2.3 Selected snapshots for TEEBAgriFood animal production systems

In poultry we distinguish between two systems: the backyard and the commercial systems (MacLeod et al., 2013; Robinson et al., 2011). The backyard systems produce for home consumption and for local markets and the feed basis is scavenging, swill and to a limited extent locally produced feed. The latter is 
often not grown on purpose and is not suitable for human consumption. Backyard systems do not specialize in meat or egg production and mainly use local breeds. The commercial systems are $100 \%$ market oriented, use specialized breeds for meat or egg production and use non-local feed resources. Within the commercial systems, there is a range in scales, from a few hundred to tens of thousands of animals. The former are often family based, while the latter use hired labour. In our study we focus on the broilers as the specialized commercial systems for meat production. For poultry three types of production systems have been selected from backyard systems in Tanzania to industrialized broiler

\section{POULTRY}

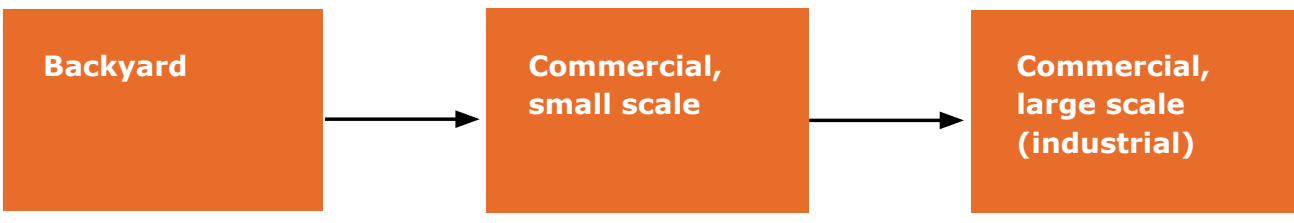

\section{CATTLE}

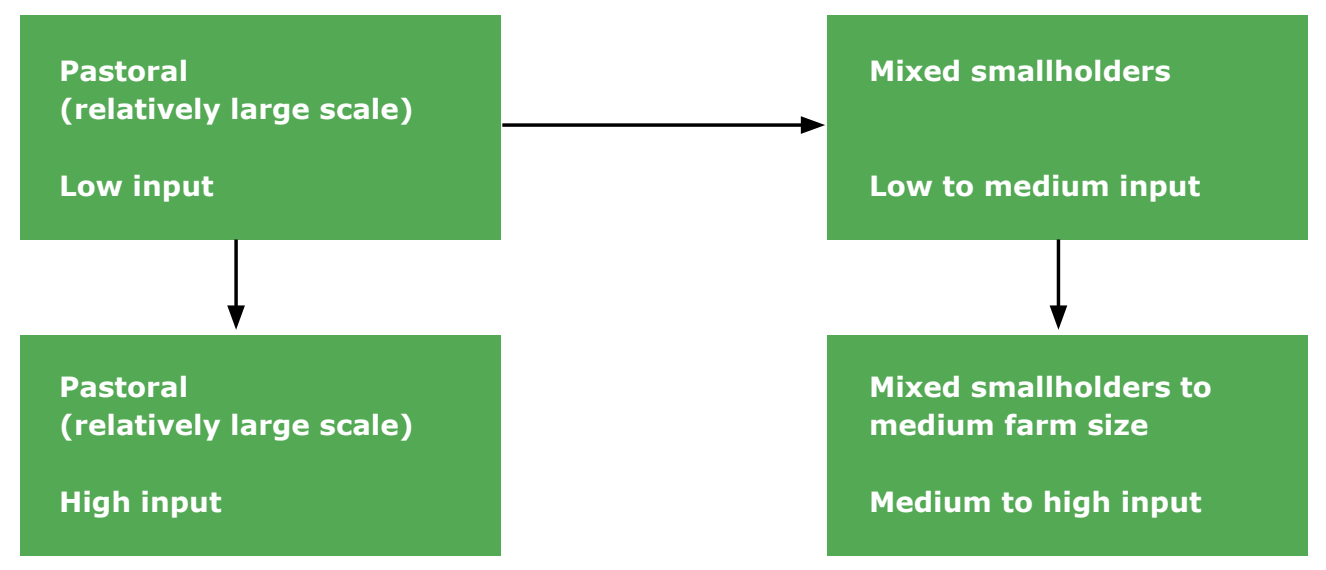

Figure 2.4 Possible development pathways for cattle and poultry production systems

systems in the Netherlands. The Indonesian poultry family farm is an in-between system that is labour intensive and capital extensive compared to the Dutch system. In size these systems are at least 10 times bigger than the more extensive example 10-30 birds; 5,000 broilers and 50,000 to 100,000 broilers.

For cattle (beef and dairy) it is a bit more complicated to categorize the livestock production systems. In many regions grasslands have been replaced by arable land and mixed systems as a result of a population increase. Very often these are subsistence farming systems, with hardly any market access. When mixed systems get market access, they tend to improve their production by higher inputs and their productivity by better management. If there is room, they tend to specialize to dairy. In regions where pastoral systems remain, intensification can go via improvement of the feed basis to higher inputs and better management. The next step can be a shift from pure grass-based to systems where the fattening stock is finished in feedlots.

Three snapshots have been selected for beef systems as well. Two of these snapshots are pastoralist systems in Tanzania and India. Both systems are very extensive in the sense that almost no additional inputs besides animals, 'pasture' and labour are used. The Brazilian beef system is the most intensive system with grazing cows and calves. The beef animals are fattened in about three months before they are slaughtered. European beef systems that confine the animals, such as in France and the Netherlands, have not been taken into account because these systems were strongly subsidy driven. The EU production subsidies (slaughter premium per animal) has been replaced by a subsidy per hectare, and the intensive beef production almost disappeared in the EU. What is left is intensive veal production (in the Netherlands, France and Italy) and extensive, completely grass-based beef production. 
Four production systems have been selected for dairy production. Three of the selected snapshots are small-scale farmers in Tanzania, India and Indonesia. Our assumption is that these farmers have five cows but operate in different countries and contexts. The Indonesian example is considered to be the most intensive one, due to its relatively high input of synthetic fertilizers and concentrates. The Dutch dairy farm is an example of intensive dairy farming but still almost all labour is supplied by family members and about $80 \%$ of the feed is produced on the farm, using a lot of inputs such as fertilizers, chemicals, concentrates, artificial insemination, financial capital, machinery and medicine.

The selected snapshots per species show a 'natural' development pathway from extensive to intensive production' (see figure 2.4). It should be noted that the development pathway should be seen as applicable at a broad global or national level. At a local scale this pathway may not apply. For instance, most backyard poultry producers will not increase production; they will remain farmers with a few chickens in the backyard or will cease production. The increase of production will be achieved by farmers who start producing in a more industrial way. These developments are only possible if the total supply chain (feed producers, veterinarians, breeders and slaughterhouses) is present, complete and adapted to local conditions.

\subsection{A comparison of top-down and bottom-up valuations}

The top-down and the bottom-up valuations are complementary approaches, as they provide answers to different questions. The top-down assessment focuses on informing decisions with a large geographical scope. It provides information with a broader coverage but a higher level of approximation. The bottom-up assessment, on the other hand, looks at sub-national policy decisions for specific cases. It makes use of regional economic and biophysical data and it is therefore limited to natural capital aspects for which local data is available or reasonable estimates can be made. A detailed illustration of the differences and similarities between the bottom-up and top-down valuations can be found in annex $B$, in which bottom-up and top-down methodologies and results are compared. 
The following table shows the key differences and similarities of the top-down materiality assessment and the bottom-up assessment of snapshots.

Table 2.8 Key differences and similarities between top-down and bottom-up valuations

\begin{tabular}{|c|c|c|c|}
\hline & Top-down & Bottom-up & $\begin{array}{l}\text { Bottom-up in-depth case } \\
\text { study: Maasai Steppe in } \\
\text { Tanzania }\end{array}$ \\
\hline Goal & $\begin{array}{l}\text { - Assess the environmental } \\
\text { externalities in the } \\
\text { livestock sector worldwide. } \\
\text { Identify the most material } \\
\text { environmental impacts } \\
\text { and geographical hotspots } \\
\text { worldwide. Determine the } \\
\text { contribution of farming } \\
\text { operations versus their } \\
\text { upstream supply chain. }\end{array}$ & $\begin{array}{l}\text { - Study a representative } \\
\text { set of livestock systems } \\
\text { around the world in terms } \\
\text { of environmental impacts. } \\
\text { - Understand differences } \\
\text { due to geographies, levels } \\
\text { of intensification, input use } \\
\text { and efficiency. }\end{array}$ & $\begin{array}{l}\text { - Quantify the value of } \\
\text { natural capital in a region } \\
\text { where livestock is one } \\
\text { of the main agricultural } \\
\text { activities. Compare } \\
\text { pastoralism with sedentary } \\
\text { farming. } \\
\text { - Understand the side } \\
\text { benefits of pastoralism and } \\
\text { assess the potential costs } \\
\text { of land conversion. }\end{array}$ \\
\hline $\begin{array}{l}\text { Natural capital aspects } \\
\text { valued }\end{array}$ & $\begin{array}{l}\text { - GHG emissions } \\
\text { - Water pollutants } \\
\text { - Air pollutants } \\
\text { - Soil pollutants } \\
\text { - Water consumption } \\
\text { - Land-use change }\end{array}$ & $\begin{array}{l}\text { - GHG emissions } \\
\text { - Water pollutants } \\
\text { - Dependency on blue water } \\
\text { (Non-monetary: land-use } \\
\text { and biodiversity change) }\end{array}$ & $\begin{array}{l}\text { - Crop and livestock } \\
\text { products } \\
\text { - Final ecosystem services } \\
\text { - Change in carbon stocks }\end{array}$ \\
\hline Object of assessment & $\begin{array}{l}\text { - Beef, milk from cows and } \\
\text { poultry meat }\end{array}$ & $\begin{array}{l}\text { Pure beef systems, dairy } \\
\text { systems (meat and milk), } \\
\text { poultry systems (meat and } \\
\text { eggs) }\end{array}$ & $\begin{array}{l}\text { - Regional rather than } \\
\text { sectoral focus. } \\
\text { - Scenarios of land use } \\
\text { change from pastoralism } \\
\text { to mixed arable and } \\
\text { livestock farming }\end{array}$ \\
\hline System boundaries & $\begin{array}{l}\text { - Livestock farming and } \\
\text { production of inputs } \\
\text { (upstream supply chain). } \\
\text { - For soil and water } \\
\text { pollutants: upstream } \\
\text { supply chain only. }\end{array}$ & $\begin{array}{l}\text { - Livestock farming and } \\
\text { production of feed. } \\
\text { - For water pollutants: on } \\
\text { farm only. } \\
\text { - For GHG: also other } \\
\text { inputs, post-farm transport } \\
\text { and processing }\end{array}$ & $\begin{array}{l}\text { Within the Maasai Steppe } \\
\text { (Tanzania), main economic } \\
\text { activity based on natural } \\
\text { capital }\end{array}$ \\
\hline $\begin{array}{l}\text { Natural capital valuation } \\
\text { methodology }\end{array}$ & $\begin{array}{l}\text { - The framework is based on } \\
\text { an integrated biophysical } \\
\text { and economic model, } \\
\text { and follows an approach } \\
\text { proposed by Keeler et al. } \\
\text { (2012). The valuations } \\
\text { are mapped to specific } \\
\text { beneficiaries and show } \\
\text { the effects on specific } \\
\text { endpoints. }\end{array}$ & $\begin{array}{l}\text { - GHG Externalities: Social } \\
\text { Cost of Carbon (same as } \\
\text { top down) } \\
\text { - Water pollution: based } \\
\text { on budget constraints } \\
\text { approach following } \\
\text { Weidema (2009). } \\
\text { - Blue water dependency: } \\
\text { imputation method (FAO, } \\
\text { 2004) adjusted with the } \\
\text { residual rent method } \\
\text { (Thompson and Johnson, } \\
\text { 2012) }\end{array}$ & $\begin{array}{l}\text { - Value transfer with local } \\
\text { market prices (PPP } \\
\text { corrected). } \\
\text { - Carbon stocks: same as } \\
\text { GHG in top-down and } \\
\text { bottom-up. }\end{array}$ \\
\hline
\end{tabular}

Both assessments consist of two steps: quantification and valuation. Quantification involves modelling environmental impacts and dependencies in biophysical terms, and valuation involves the monetization of those so that different aspects become comparable.

The top-down analysis has a broad geographic scope and the bottom-up analysis has a high level of granularity for both the quantification and valuation steps (see table A in annex B). In terms of quantification the key differences involve the system boundaries, the object of the assessment and the type of data sources used. In the case of GHG, the same social cost of carbon is used. For the rest of the impacts or dependencies, the valuation methodologies differ and are explained in detail in separate reports 
(Trucost 2016; True Price, 2016). On the other hand, the in-depth case study on pastoralism in the Maasai region is the most detailed case of bottom-up valuation, as it uses all region-specific monetary and biophysical values of environmental goods and services.

An important fact contributing to the disparity in the results is the quantification step. As provided in table 2.9, the granularity of data sources used to quantify environmental impacts differs in the top-down and the bottom-up.

Table 2.9 Level of detail of input parameters for the quantification of impacts

\begin{tabular}{lll}
\hline $\begin{array}{l}\text { Livestock production } \\
\text { system-specific data }\end{array}$ & $\begin{array}{l}\text { No differentiation between production } \\
\text { systems. }\end{array}$ & $\begin{array}{l}\text { Bottom-up } \\
\text { impacts. }\end{array}$ \\
\hline Country-specific data & $\begin{array}{l}\text { On-farm impacts whenever data is available. } \\
\text { Total volumes of livestock commodities } \\
\text { produced per country. }\end{array}$ & $\begin{array}{l}\text { Impacts of feed production in the supply } \\
\text { chain. }\end{array}$ \\
\hline Global data & $\begin{array}{l}\text { Upstream supply chain impacts (i.e. feed } \\
\text { production, farm inputs). }\end{array}$ & $\begin{array}{l}\text { Downstream GHG emissions, selected } \\
\text { modelling parameters (from IPCC). }\end{array}$ \\
\hline
\end{tabular}

To guarantee a degree of consistency among the two approaches, the same valuation methodologies for natural capital costs from GHG emissions have been applied in the bottom-up and in the top-down valuations.

However, both analyses address the land use change and water footprint impacts, but from a different perspective. Both the approaches for land-use change are based on the quantification of land-use change related to the expansion of livestock systems and the valuation of ecosystem services provided by the land. In the case of water, the two approaches look at two different sides of the issue. The use of water by agriculture has an external cost, namely the cost of reducing water availability, and an economic value, namely the benefit of using water to increase crop yields. The former constitutes an external cost used in the top-down approach, the latter a dependency of farming on ecosystems, used in the bottom-up approach. 


\section{Top-down results}

\subsection{Top-down approach}

\subsubsection{Introduction}

The objectives of the top-down approach are: (1) to summarize the benefits provided by livestock systems in terms of ecosystem services; (2) to compare the costs of the three sectors on natural capital both in absolute terms and per unit of animal protein produced; (3) to identify the most material natural capital costs and geographical hotspots worldwide; (4) to assess the contribution of farming operations versus their upstream supply chain, and; (5) to contextualize the selected snapshots. ${ }^{17}$

This chapter will present the following results:

Natural capital benefits: The benefits provided by livestock sectors and their link to specific ecosystem services is briefly described in a qualitative way in section 3.1.2. This section also contains the quantitative assessment of food provisioning services for a sample of countries and the quantitative assessment of manure provisioning for the USA.

Natural capital costs: Natural capital costs express in monetary terms the impacts on natural capital from livestock production as a result of resource use and pollutant emissions (units in US\$). Total natural capital costs are determined considering all producing countries in each sector and are expressed in million US\$ (section 3.1.3). The natural capital cost for the top-five contributing countries and their contribution to the total natural capital cost is highlighted in sections $\underline{3.1 .5}, \underline{3.1 .6}$ and 3.1.7. Particular attention has been devoted to the key contributing countries that were selected for the snapshots. These results broadly illustrate the countries and regions where the production of a certain animal commodity is concentrated.

Natural capital intensities: Natural capital intensities are defined as the natural capital costs per tonne of protein generated (units in US\$ per tonne protein). Global average natural capital intensities are provided in section 3.1.4. Natural capital intensities for the top-five contributing countries are provided in sections $\underline{3.1 .5}, \underline{3.1 .6}$ and $\underline{3.1 .7}$. These results highlight the varying efficiency of livestock production systems and the magnitude of the natural capital coefficients across countries.

\subsubsection{Natural capital benefits}

The top-down approach focuses on the natural capital costs of livestock production systems. However, livestock systems can provide or enhance a range of ecosystem services underpinning the provision of natural capital benefits. The analysis of natural capital benefits is divided into a quantitative analysis focusing only on the provision of food and manure as fertilizer, and a qualitative analysis which looks at a broader scope of the ecosystem services provided by livestock systems.

When providing context for the snapshots, several aspects have to be taken into account. First, as opposed to the bottom-up approach used in the snapshots, the top-down approach does not differentiate between farming systems. Thus, the results of the top-down analysis are expected to be in line with the most common farming system of the country for each livestock sector. Second, in the top-down approach, the assessment is done at the product level of beef, dairy milk and poultry meat. By contrast, in the snapshots the assessment is done at the production system level for pure beef, dairy (producing both milk and meat) and poultry systems (producing meat and eggs). This means that the results of the top-down approach and bottom-up approach cannot be directly compared. For a more detailed comparison of the two approaches see annex B. 


\section{Quantitative analysis}

\section{Provisioning services}

Ecosystems provide the essential conditions for the production of animal feed, and in turn underpin the productivity of livestock systems (TEEB, n.d.). Livestock (through meat, eggs and milk) is estimated to provide $26 \%$ of global human protein consumption and $13 \%$ to total calorie intake, whilst providing a concentrated source of bioavailable micronutrients (Hoffmann et al., 2014). Livestock also represents an important risk mitigation strategy for vulnerable populations, providing both a source of nutrients (through manure) and draught power for crop production, as well as an additional source of food and income (Thornton, 2010).

The provision of food and raw materials are important services provided by livestock systems. Table 3.1 and table 3.2 provide the average retail price of meat and dairy products in major producing countries: China, Brazil and the USA. For the USA, the estimated fertilizer value of manure produced by livestock is also provided.

Retail prices for the USA represent the average local price for the 2015 calendar year until September collected by the United States Department of Agriculture, Economic Research Service (USDA, 2012). The retail price for beef (US\$12.70 per $\mathrm{kg}$ ) represents an average of prices for available beef cuts with prices ranging from US $\$ 9.25$ per $\mathrm{kg}$ for ground beef to US $\$ 18.87$ per $\mathrm{kg}$ for sirloin steak. The retail price for chicken represents the price for boneless chicken breast (US\$7.58 per $\mathrm{kg}$ ). The retail price for milk represents the price per litre for fresh whole milk.

Retail prices for Brazil represent the average local price for the 2015 calendar year until September collected by the Brazilian Institute of Agricultural Economics (Instituto de Economía Agrícola, 2015). Beef and chicken prices are presented as the average retail price for carne bovina (beef) and Filé de Frango (chicken filet), respectively. The retail price for milk represents the average of prices for different milk types as reported by the Brazilian Institute of Agricultural Economics (ibid). Prices were reported in Brazilian Real and converted to US dollars.

Prices for beef, chicken and milk in China were sourced from the Chinese Ministry of Agriculture (MOA, 2015). Prices were reported in Chinese Yuan Renminbi $(¥)$ and converted to US dollars. Retail prices for chicken, beef and milk represent the average prices reported by MOA (2015) current as at October 2015 per kilogram of fresh whole chicken, national average beef, and per kilogram of raw milk, respectively.

In table 3.1 and 3.2 prices have been converted to per $\mathrm{kg}$ protein to allow comparability with the natural capital intensities presented in section 3.1.4.

\section{Table 3.1 Retail price in US\$/kg protein}

\begin{tabular}{llll} 
Country & Chicken & Beef & Milk \\
\hline China & 34,24 & 53,76 & 16,95 \\
\hline Brazil & 21,81 & 35,29 & 31,11 \\
\hline
\end{tabular}

Source: China - MOA (2015); Brazil - Instituto de Economia Agricola (2015). 
Table 3.2 Retail price for chicken meat, beef and milk as well as manure value for the USA in US\$/kg protein.

\begin{tabular}{lllllll} 
Country & Chicken & \multicolumn{2}{c}{ Beef } & \multicolumn{3}{c}{ Milk } \\
& Retail price & Manure Value & Retail price & Manure value & Retail price & Manure value \\
\hline USA & 39,88 & 0,67 & 66,84 & 7,42 & 26,58 & 0,59
\end{tabular}

Source: Retail prices - USDA (2015), Manure - USDA (2013), Brown (2013)

Manure production as an organic fertilizer was valued for the USA based on the retail price of chemical fertilizers required to deliver an equivalent quantity of nitrogen, phosphorus and potassium as is contained within a kilogram of manure. The nutrient content of manure was estimated based on Brown (2013) and valued based on USA retail fertilizer prices reported in USDA (2013), and inflated to 2015 prices based on the USA consumer price index as reported by the World Bank (2015a). Values were then converted from US $\$ / \mathrm{kg}$ manure to US $\$ / \mathrm{kg}$ protein by combining the annual manure production for broilers, beef cattle and dairy cattle from Brown (2016) with the production of chicken meat, beef and dairy milk from FAO (2015a).

Potter et al. (2010) estimate that the application of manure as a fertilizer for crop production provided up to $65 \%$ of the total quantity of nitrogen, and $63 \%$ of total phosphorus, applied globally in 2000 . The importance of manure as a nutrient source can be even greater in developing countries that have less access to chemical fertilizers. Animal manure also provides an important source of energy for rural communities, both in its direct use as a biomass fuel and in the production of methane for energy through anaerobic digestion. The increasing use of anaerobic digestion offers duel greenhouse gas mitigation benefits in the displacement of fossil fuel sources with biogas and the reduction in direct nitrous oxide emissions from manure (Gerber et al., 2013).

\section{Qualitative analysis}

Examples of potential positive ecosystem services arising from livestock systems are described briefly below for the categories of provisioning, regulating, supporting and habitat, and cultural services.

Table 3.3 provides an overview of the range of possible ecosystem service benefits provided or supported by livestock production systems, focusing on grassland grazing systems, mixed rainfed systems, landless ruminant production systems, and landless monogastric systems. As explained in table 3.3, those services can be realized on short, medium and long-term temporal scales, and at local, regional and global spatial scales.

\section{Provisioning services}

Beyond the production of food and materials, livestock production systems offer a range of other provisioning services.

Draught animal power represents an essential energy resource for agricultural work and transport in many countries, and is sometimes the only feasible energy source in some mountainous and inaccessible areas (Hoffmann et al., 2014). FAO projections of the use of draught animal power in 2030, presented in Hoffman et al. (2014), range from $30 \%$ in sub-Saharan Africa to $10 \%$ in the Near East and North Africa, highlighting the importance of animals for traction power in developing countries. 


\section{Regulating services}

Human well-being benefits from the ecosystem's role as a regulator of a range of natural processes, including the regulation of local air quality, climate, erosion, soil fertility and pollination (TEEB, n.d.). Livestock can impact both positively and negatively on the regulating services provided by ecosystems. Livestock systems are capable of converting non-human edible primary vegetation, agricultural residues and other household wastes into protein for human consumption whilst recycling the nutrients contained in these wastes back into ecosystems (Hoffmann et al., 2014). Appropriately managed livestock grazing can also help to prevent erosion, improve water retention and improve soil carbon sequestration by helping to maintain soil cover and providing organic matter and nutrients to poor quality soils (ibid). Grazing can also prevent the encroachment of woody species into grasslands to maintain habitat diversity (Perevolotsky and Seligman, 1998). Improved soil quality can also improve soil organic carbon sequestration with implications for climate regulation (Hoffmann et al., 2014).

Livestock systems can also contribute to the control of agricultural pests and disease vectors by consuming insects and supporting the maintenance of populations of pollinator species by controlling tall grasses that may otherwise supress the growth of floral species on which they depend (Hoffmann et al., 2014).

\section{Supporting and habitat services}

Supporting ecosystem services, such as the maintenance of genetic diversity, are intermediate services that underpin final provisioning, regulating and cultural services that benefit humans (Haines-Young and Potschin, 2009). Zander et al. (2013) and Martin-Collado et al. (2014) showed that in the case of threatend European livestock breeds, livestock systems have significant public value in generating resource diversity. Livestock systems can also connect habitats through the dispersal of seeds across geographies, enabling the movement of plant species in response to the changing climate (Hoffmann et al., 2014). Furthermore, livestock production systems can support soil fertility through the cycling of nutrients and the provision of organic matter in the form of manure, and can also provide habitats for species and ecosystems that have adapted to human created biotopes (ibid).

\section{Cultural services}

Cultural services provided by ecosystems encompass a broad range of non-material benefits that underpin human recreation, culture and spirituality (Haines-Young and Potschin, 2009). Livestock provide a range of cultural services through their use as a source of recreation, aesthetics and inspiration, and through their role in the fulfilment of social and religious rituals and obligations (Hoffmann et al., 2014). For example:

- In addition to their use as an important source of food and income, chickens are used in Kenya as part of traditional funeral rites, as gifts, and as a biological clock to tell the time of day in rural areas (Magothe et al., 2012). Furthermore, livestock in East Africa represent a means of assuring cultural ties and support the building of social capital between groups and communities, through, for example, inheritance and loans, and through the use of livestock as an indicator of social status and in marriage rituals (Hesse and MacGregor, 2006).

- In Russia, the Yakutian cattle breed plays an important role in maintaining and strengthening the ethnic and regional identity of the local Sakha people (Kantanen et al., 2010), and the cattle breed is used as part of traditional funeral rituals (Ovaska and Soini, 2011).

- Livestock systems are also key to the preservation of aesthetically important landscapes, such as the rangeland landscape in the USA, which is associated with grazing cattle production (Huntsinger, 2013). The transformation of traditional grassland landscapes into scrub and evergreen oak forest in in Provence, France due (in part) to the abandonment of sheep grazing, highlights the importance of livestock systems in maintaining culturally important landscapes (Bunce et al., 2004).

- The maintenance of livestock systems can be an important factor in conserving traditional knowledge about the coexistence of humans, nature and livestock that has been developed over long periods of time. Such knowledge can inform the development of management practices that are optimized for specific livestock breeds and environmental conditions (Hoffmann et al., 2014).

- A 2012 study examined the contribution of Tanzanian pastoralist systems to the wildlife tourism industry. These benefits accrue due to the conservation of water and pastures, and the preservation of natural ecosystems, through locally derived land management practices implemented by pastoral communities (Nelson, 2012). 
Table 3.3 Ecosystem service benefits provided by livestock production systems (adapted from Hoffmann et al., 2014)

\begin{tabular}{|c|c|c|c|c|c|c|c|c|}
\hline $\begin{array}{l}\text { Ecosystem } \\
\text { service }\end{array}$ & $\begin{array}{l}\text { Temporal } \\
\text { scale }\end{array}$ & $\begin{array}{l}\text { Spatial } \\
\text { scale }\end{array}$ & $\begin{array}{l}\text { Grassland } \\
\text { (grazing) } \\
\text { systems }\end{array}$ & $\begin{array}{l}\text { Mixed } \\
\text { rainfed } \\
\text { systems }\end{array}$ & $\begin{array}{l}\text { Landless } \\
\text { ruminant } \\
\text { systems } \\
\text { (feed- } \\
\text { lotting) }\end{array}$ & $\begin{array}{l}\text { Landless } \\
\text { monogastric } \\
\text { systems } \\
\text { (backyard } \\
\text { poultry) }\end{array}$ & Mechanism & $\begin{array}{l}\text { Example } \\
\text { products } \\
\text { and benefits }\end{array}$ \\
\hline
\end{tabular}

\section{Provisioning Services}

\begin{tabular}{|c|c|c|c|c|c|c|c|c|}
\hline $\begin{array}{l}\text { Food, hides, } \\
\text { skins and fibres }\end{array}$ & $\mathrm{S}$ & $L, R, G$ & + & +++ & ++++ & ++++ & $\begin{array}{l}\text { Benefits and } \\
\text { co-benefits } \\
\text { of animal } \\
\text { secondary } \\
\text { productivity }\end{array}$ & Meat, leather \\
\hline Draught power & $\mathrm{S}$ & $\mathrm{L}$ & $\mathrm{N} / \mathrm{A}$ & ++++ & $\mathrm{N} / \mathrm{A}$ & $\mathrm{N} / \mathrm{A}$ & & $\begin{array}{l}\text { Draught } \\
\text { power }\end{array}$ \\
\hline Fertilizer & $\mathrm{S}$ & $L, R$ & + & +++ & ++ & ++ & & Manure, urine \\
\hline Fuel & $\mathrm{S}$ & $\mathrm{L}$ & $\mathrm{N} / \mathrm{A}$ & + & ++ & ++ & $\begin{array}{l}\text { Combustion, } \\
\text { fermentation }\end{array}$ & $\begin{array}{l}\text { Manure, } \\
\text { biogas }\end{array}$ \\
\hline \multicolumn{9}{|c|}{ Regulating services } \\
\hline $\begin{array}{l}\text { Non-human } \\
\text { edible food } \\
\text { conversion } \\
\text { - primary } \\
\text { vegetation }\end{array}$ & $\mathrm{S}$ & $\mathrm{L}$ & ++++ & ++++ & + & + & $\begin{array}{l}\text { Conversion } \\
\text { of feed to } \\
\text { biomass }\end{array}$ & $\begin{array}{l}\text { Use of } \\
\text { primary } \\
\text { vegetation for } \\
\text { feed }\end{array}$ \\
\hline $\begin{array}{l}\text { Waste Recycling } \\
\text { and weed } \\
\text { control }\end{array}$ & $\mathrm{S}$ & $\mathrm{L}$ & + & ++++ & + & + & $\begin{array}{l}\text { Feeding of } \\
\text { animal and } \\
\text { plant waste } \\
\text { residues and } \\
\text { grazing on } \\
\text { weeds }\end{array}$ & $\begin{array}{l}\text { Recycling of } \\
\text { crop residues } \\
\text { and household } \\
\text { waste }\end{array}$ \\
\hline $\begin{array}{l}\text { Biological } \\
\text { Control }\end{array}$ & $\mathrm{S}$ & $\mathrm{L}$ & ++ & ++ & $\mathrm{N} / \mathrm{A}$ & $\mathrm{N} / \mathrm{A}$ & $\begin{array}{l}\text { Consumption } \\
\text { of disease } \\
\text { carrying } \\
\text { insects, e.g. } \\
\text { ticks }\end{array}$ & $\begin{array}{l}\text { Reduction } \\
\text { of disease } \\
\text { vectors and } \\
\text { pest species }\end{array}$ \\
\hline $\begin{array}{l}\text { Land } \\
\text { Degradation } \\
\text { and Erosion } \\
\text { Prevention }\end{array}$ & $M, L$ & $L, R$ & ++ & ++ & N/A & N/A & \multirow{3}{*}{$\begin{array}{l}\text { Managed } \\
\text { grazing can } \\
\text { enhance } \\
\text { soil quality } \\
\text { and fertility, } \\
\text { soil water } \\
\text { retention, } \\
\text { soil carbon } \\
\text { formation } \\
\text { and local } \\
\text { biodiversity }\end{array}$} & $\begin{array}{l}\text { Maintenance } \\
\text { of vegetation } \\
\text { cover }\end{array}$ \\
\hline $\begin{array}{l}\text { Climate } \\
\text { Regulation }\end{array}$ & $\mathrm{L}$ & G & ++++ & ++ & $\mathrm{N} / \mathrm{A}$ & $\mathrm{N} / \mathrm{A}$ & & $\begin{array}{l}\text { Soil carbon } \\
\text { sequestration }\end{array}$ \\
\hline $\begin{array}{l}\text { Water Quality/ } \\
\text { Quantity } \\
\text { Regulation }\end{array}$ & $M, L$ & $L, R$ & ++++ & +++ & $\mathrm{N} / \mathrm{A}$ & $\mathrm{N} / \mathrm{A}$ & & $\begin{array}{l}\text { Water } \\
\text { purification } \\
\text { in soil }\end{array}$ \\
\hline $\begin{array}{l}\text { Control of bush } \\
\text { encroachment } \\
\text { and } \\
\text { maintenance of } \\
\text { fuel breaks }\end{array}$ & $S, M$ & $\mathrm{~L}$ & ++++ & N/A & $\mathrm{N} / \mathrm{A}$ & $\mathrm{N} / \mathrm{A}$ & $\begin{array}{l}\text { Browsing } \\
\text { species } \\
\text { consume } \\
\text { woody } \\
\text { vegetation } \\
\text { and keep } \\
\text { rangelands } \\
\text { open }\end{array}$ & $\begin{array}{l}\text { Prevention of } \\
\text { overgrowth } \\
\text { and } \\
\text { containment } \\
\text { of fire hazards }\end{array}$ \\
\hline Pollination & $\mathrm{S}$ & $\mathrm{L}$ & $x X$ & ++++ & $\mathrm{N} / \mathrm{A}$ & $\mathrm{N} / \mathrm{A}$ & $\begin{array}{l}\text { Managed } \\
\text { grazing can } \\
\text { improve floral } \\
\text { resources, } \\
\text { particularly } \\
\text { where } \\
\text { supressed by } \\
\text { tall grasses }\end{array}$ & $\begin{array}{l}\text { Increased } \\
\text { population } \\
\text { of pollinating } \\
\text { species }\end{array}$ \\
\hline
\end{tabular}


Table 3.3 -sequence

\begin{tabular}{|c|c|c|c|c|c|c|c|c|}
\hline $\begin{array}{l}\text { Ecosystem } \\
\text { service }\end{array}$ & $\begin{array}{l}\text { Temporal } \\
\text { scale }\end{array}$ & $\begin{array}{l}\text { Spatial } \\
\text { scale }\end{array}$ & $\begin{array}{l}\text { Grassland } \\
\text { (grazing) } \\
\text { systems }\end{array}$ & $\begin{array}{l}\text { Mixed } \\
\text { rainfed } \\
\text { systems }\end{array}$ & $\begin{array}{l}\text { Landless } \\
\text { ruminant } \\
\text { systems } \\
\text { (feed- } \\
\text { lotting) }\end{array}$ & $\begin{array}{l}\text { Landless } \\
\text { monogastric } \\
\text { systems } \\
\text { (backyard } \\
\text { poultry) }\end{array}$ & Mechanism & $\begin{array}{l}\text { Example } \\
\text { products } \\
\text { and benefits }\end{array}$ \\
\hline
\end{tabular}

\section{Supporting services and habitat services}

\begin{tabular}{|c|c|c|c|c|c|c|c|c|}
\hline $\begin{array}{l}\text { Maintenance of } \\
\text { soil fertility }\end{array}$ & $\mathrm{S}, \mathrm{N}$ & $\mathrm{L}$ & + & +++ & $\mathrm{N} / \mathrm{A}$ & $\mathrm{N} / \mathrm{A}$ & $\begin{array}{l}\text { Provision of } \\
\text { nutrients and } \\
\text { organic matter }\end{array}$ & $\begin{array}{l}\text { Nutrient } \\
\text { cycling and } \\
\text { soil formation }\end{array}$ \\
\hline $\begin{array}{l}\text { Primary } \\
\text { production }\end{array}$ & $S, M$ & $\mathrm{~L}$ & ++ & N/A & $\mathrm{N} / \mathrm{A}$ & $\mathrm{N} / \mathrm{A}$ & $\begin{array}{l}\text { Managed } \\
\text { grazing can } \\
\text { enhance } \\
\text { soil quality } \\
\text { and fertility, } \\
\text { soil water } \\
\text { retention, } \\
\text { soil carbon } \\
\text { formation } \\
\text { and local } \\
\text { biodiversity }\end{array}$ & $\begin{array}{l}\text { Improving } \\
\text { vegetation } \\
\text { cover }\end{array}$ \\
\hline $\begin{array}{l}\text { Connecting } \\
\text { habitats }\end{array}$ & $M$ & $L, R$ & ++++ & ++ & $\mathrm{N} / \mathrm{A}$ & N/A & $\begin{array}{l}\text { Seasonal } \\
\text { grazing can } \\
\text { connect } \\
\text { ecosystems } \\
\text { by distributing } \\
\text { seeds }\end{array}$ & $\begin{array}{l}\text { Enabling } \\
\text { movement of } \\
\text { vegetation to } \\
\text { new habitats } \\
\text { in changing } \\
\text { climates }\end{array}$ \\
\hline $\begin{array}{l}\text { Maintenance } \\
\text { of life-cycles of } \\
\text { species }\end{array}$ & $M, L$ & $\mathrm{~L}$ & ++++ & ++ & $\mathrm{N} / \mathrm{A}$ & N/A & $\begin{array}{l}\text { Preventing } \\
\text { succession and } \\
\text { maintaining } \\
\text { avian, insect } \\
\text { and predator } \\
\text { diversity on } \\
\text { human made } \\
\text { biotopes }\end{array}$ & $\begin{array}{l}\text { Habitats for } \\
\text { migratory } \\
\text { species } \\
\text { Habitats } \\
\text { for species } \\
\text { adapted to } \\
\text { human-made } \\
\text { biotopes }\end{array}$ \\
\hline $\begin{array}{l}\text { Maintenance } \\
\text { of genetic } \\
\text { diversity }\end{array}$ & $S, M, L$ & $L, R, G$ & ++++ & ++ & N/A & N/A & $\begin{array}{l}\text { Maintenance } \\
\text { of sub-species } \\
\text { (breed) level } \\
\text { diversity } \\
\text { through local } \\
\text { adaptation }\end{array}$ & $\begin{array}{l}\text { Gene pool } \\
\text { protection }\end{array}$ \\
\hline
\end{tabular}

\section{Cultural services}

\begin{tabular}{|c|c|c|c|c|c|c|c|c|}
\hline $\begin{array}{l}\text { Opportunities } \\
\text { for recreation }\end{array}$ & $M, L$ & $L, R$ & ++++ & ++ & N/A & $\mathrm{N} / \mathrm{A}$ & $\begin{array}{l}\text { Unique and/or } \\
\text { aesthetically } \\
\text { pleasing } \\
\text { landscapes } \\
\text { may attract } \\
\text { tourists }\end{array}$ & $\begin{array}{l}\text { Eco/Agro- } \\
\text { tourism }\end{array}$ \\
\hline $\begin{array}{l}\text { Knowledge } \\
\text { systems and } \\
\text { education }\end{array}$ & $M$ & $\mathrm{~L}$ & ++++ & ++ & N/A & $\mathrm{N} / \mathrm{A}$ & $\begin{array}{l}\text { Developing an } \\
\text { understanding } \\
\text { of the } \\
\text { coexistence } \\
\text { of nature, } \\
\text { humans and } \\
\text { livestock over } \\
\text { time }\end{array}$ & $\begin{array}{l}\text { Traditional } \\
\text { and formal } \\
\text { breed } \\
\text { knowledge } \\
\text { Enhanced } \\
\text { livestock } \\
\text { management }\end{array}$ \\
\hline $\begin{array}{l}\text { Cultural and } \\
\text { historic heritage }\end{array}$ & $M, L$ & $\mathrm{~L}$ & ++++ & +++ & N/A & N/A & $\begin{array}{l}\text { Use of animals } \\
\text { in cultural, } \\
\text { social and } \\
\text { spiritual } \\
\text { activities }\end{array}$ & $\begin{array}{l}\text { Maintenance } \\
\text { of cultural } \\
\text { identity }\end{array}$ \\
\hline $\begin{array}{l}\text { Art, culture and } \\
\text { design }\end{array}$ & $M$ & $L, R$ & ++++ & ++++ & N/A & $\mathrm{N} / \mathrm{A}$ & $\begin{array}{l}\text { Inspiration } \\
\text { for artists and } \\
\text { designers }\end{array}$ & $\begin{array}{l}\text { Traditional } \\
\text { arts and } \\
\text { fashion }\end{array}$ \\
\hline
\end{tabular}


Table 3.3 -sequence

\begin{tabular}{|c|c|c|c|c|c|c|c|c|}
\hline $\begin{array}{l}\text { Ecosystem } \\
\text { service }\end{array}$ & $\begin{array}{l}\text { Temporal } \\
\text { scale }\end{array}$ & $\begin{array}{l}\text { Spatial } \\
\text { scale }\end{array}$ & $\begin{array}{l}\text { Grassland } \\
\text { (grazing) } \\
\text { systems }\end{array}$ & $\begin{array}{l}\text { Mixed } \\
\text { rainfed } \\
\text { systems }\end{array}$ & $\begin{array}{l}\text { Landless } \\
\text { ruminant } \\
\text { systems } \\
\text { (feed- } \\
\text { lotting) }\end{array}$ & $\begin{array}{l}\text { Landless } \\
\text { monogastric } \\
\text { systems } \\
\text { (backyard } \\
\text { poultry) }\end{array}$ & Mechanism & $\begin{array}{l}\text { Example } \\
\text { products } \\
\text { and benefits }\end{array}$ \\
\hline $\begin{array}{l}\text { Natural } \\
\text { (landscape) } \\
\text { heritage }\end{array}$ & $M, L$ & $L, R$ & ++++ & +++ & $\mathrm{N} / \mathrm{A}$ & $\mathrm{N} / \mathrm{A}$ & $\begin{array}{l}\text { Formation } \\
\text { of unique } \\
\text { landscapes } \\
\text { through the } \\
\text { interaction of } \\
\text { agricultural } \\
\text { systems and } \\
\text { the natural } \\
\text { environment }\end{array}$ & $\begin{array}{l}\text { Aesthetic } \\
\text { value }\end{array}$ \\
\hline $\begin{array}{l}\text { Spiritual and } \\
\text { religious } \\
\text { experiences }\end{array}$ & $M, L$ & L & ++++ & +++ & N/A & $\mathrm{N} / \mathrm{A}$ & $\begin{array}{l}\text { Roles for } \\
\text { animals in } \\
\text { religious rituals }\end{array}$ & $\begin{array}{l}\text { Religious } \\
\text { ceremonies, } \\
\text { funerals and } \\
\text { weddings }\end{array}$ \\
\hline
\end{tabular}

Note: Scale refers to the importance of the ecosystem service to each production system; + (low) to ++++ (high).

Spatial scale: Local (L), Regional (R) and Global (G)

Temporal scale: Short (S), Medium (M) and Long (L) term

\subsubsection{Total natural capital costs}

This section provides an overview of the total natural capital cost associated with beef, dairy milk and poultry meat production. As mentioned previously, total costs are calculated considering all producing countries for beef, dairy milk and poultry meat, and thus represent the impacts of those sectors at a global scale. These costs are divided into upstream supply chain and direct operations, as Trucost's EEIO model divides the impacts by stage in the value chain. Once the direct and indirect cost were obtained for each of the producing countries, those were aggregated in order to obtain the costs at a global scale.

A comparison of the total natural capital costs for beef, dairy milk and poultry meat production is provided in figure 3.1. Natural capital costs are expressed in million US\$ inflated to 2015 prices. Production quantities are measured in tonnes of product: tonnes of meat for beef and poultry production, and tonnes of milk for dairy production.

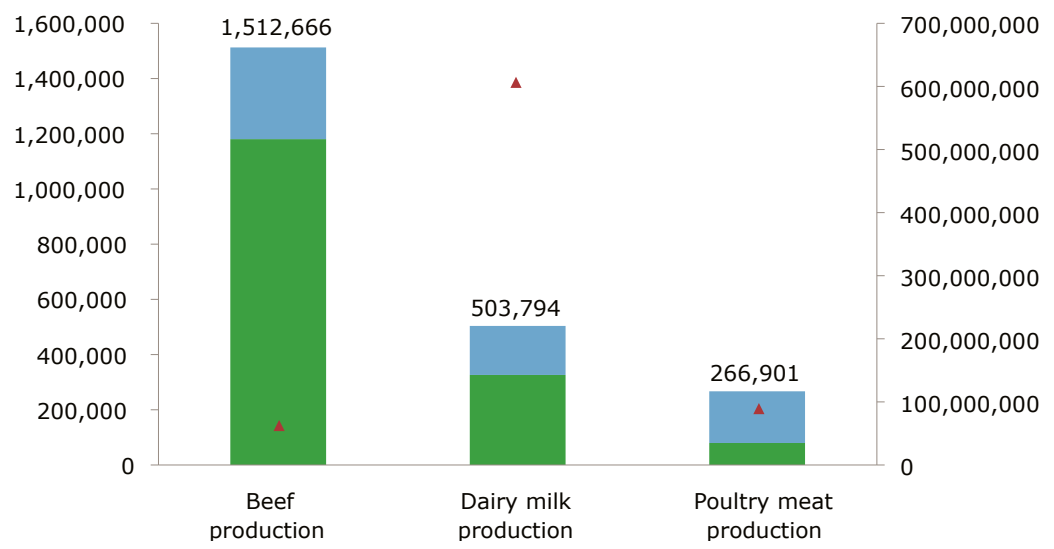

Figure 3.1 Total natural capital cost of beef, dairy and poultry production worldwide (in million US\$) and production quantities (in tonnes) 
Beef production has the greatest impact on natural capital at a global scale, and thus the highest natural capital cost, as shown in figure 3.1. The total natural capital cost of beef cattle production is US $\$ 1.5$ trillion, across all 199 beef cattle producing countries. In the case of dairy milk production, the total natural capital cost is US\$0.5 trillion across 191 producing countries. For poultry meat, the total natural capital cost is almost 0.26 US $\$$ trillion across 201 producing countries. Thus, the total natural capital cost of beef production worldwide is more than three times that of milk production and approximately six times higher than poultry production.

In 2011, global production quantities for each of the sectors were: 63 million tonnes of beef, 89 million tonnes of chicken meat and 607 million tonnes of dairy milk (FAO, 2015a). While production quantities are higher for poultry, the total natural capital cost associated with beef production is much greater than for poultry. This is due to the higher natural capital intensity of this sector (higher natural capital cost per production quantity).

For beef production, most of the natural capital cost is associated with direct operations. When considering all producing countries, direct operations of beef production account for $78 \%$ of the natural capital cost. For dairy milk production, there is a similar split for direct operations and supply chain impacts; direct operations account for $65 \%$ of the natural capital cost with the remaining $35 \%$ coming from the supply chain. There is a higher impact associated with the supply chain in milk production as dairy systems rely to a greater extent on feed purchased off farms instead of in pastures. In the case of poultry meat, most of the natural capital cost occurs in the supply chain - by a long chalk. Only $29 \%$ of the natural capital cost of poultry meat production is associated with direct operations. The remaining $71 \%$ relates to the supply chain. Compared to beef, poultry meat requires less land to raise animals, and poultry has lower GHG emissions occurring within the farming stage as poultry does not produce methane emissions from enteric fermentation. In addition, poultry production normally relies on purchased feed grown off-farm, which contributes to its high supply chain impacts.

\subsubsection{Natural capital intensities}

This section provides worldwide average natural capital intensities for each of the three livestock sectors. Average natural capital intensities were obtained by combining the natural capital costs and production quantities obtained in section 3.1.3, with the protein content of each commodity. Average values presented in the report are weighted by production quantity. The intensity represents the impact on natural capital associated with the production of one unit of each commodity. This parameter makes it possible to identify the commodity that provides the greatest amount of protein with the lowest impact on natural capital.

Figure 3.2 presents the average natural capital intensity when considering all producing countries for beef, dairy and poultry production split by the type of natural capital impact. The results are expressed in US\$ per kilogram of protein produced.

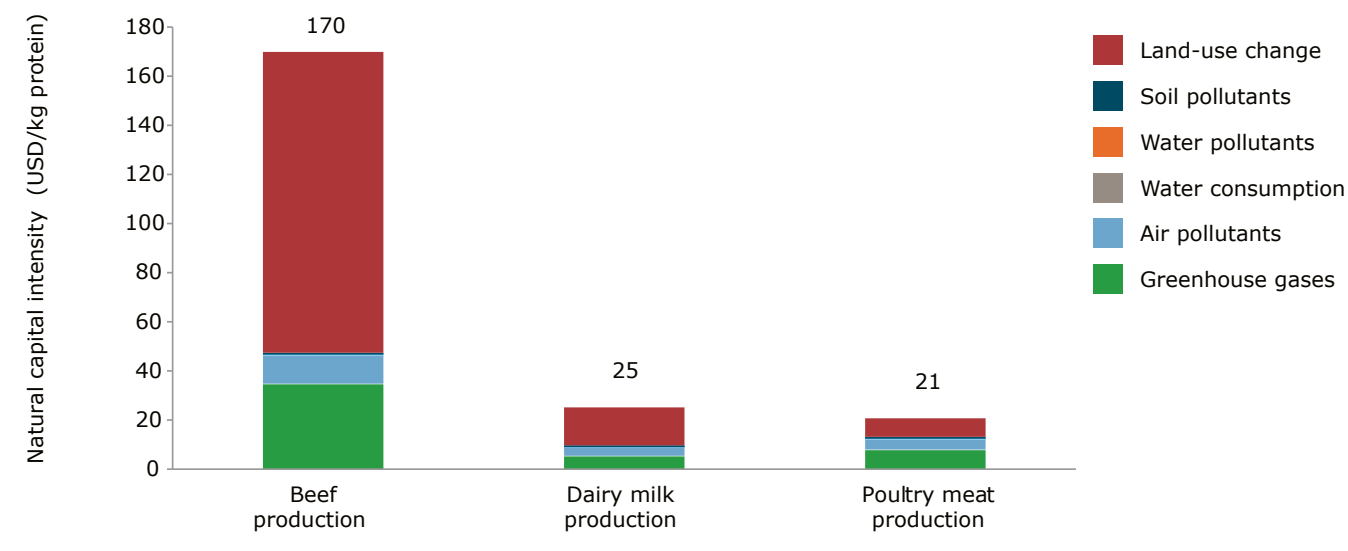

Figure 3.2 Average natural capital intensity split by natural capital impact of beef, poultry meat and dairy milk production (in US $\$ / \mathrm{kg}$ protein) 
As figure 3.2 illustrates, the production of poultry meat has the lowest natural capital intensity of the three commodities (US\$21 per kg of animal protein); 88\% lower than beef (US\$170 per $\mathrm{kg}$ of animal protein) and $18 \%$ lower than milk (US $\$ 25$ per $\mathrm{kg}$ of animal protein). Based on these figures, poultry is the most environmentally efficient commodity, followed by dairy and beef. This is due to a combination of the high protein content of poultry meat (19\% versus $3.3 \%$ for milk) and a low impact on natural capital, such as land use and GHG emissions. Lower impacts on natural capital are explained by the lack of enteric fermentation in poultry, and its lower feed conversion rates (lower kilogram of feed needed per kilogram of output) when compared to cattle.

Among the top-five countries per livestock sector, the natural capital intensity varies for beef from US $\$ 270$ per $\mathrm{kg}$ of protein in Brazil to US\$101 per $\mathrm{kg}$ of protein in China. For dairy milk this value varies from US $\$ 35$ per $\mathrm{kg}$ of protein in Brazil to US $\$ 22$ per $\mathrm{kg}$ of protein in India. For poultry meat, the natural capital intensity varies from US $\$ 58$ per $\mathrm{kg}$ of protein in Indonesia ${ }^{18}$ to US\$15 per $\mathrm{kg}$ of protein in United States. Similar findings were obtained by Cranfield University and Defra (Williams et al., 2006). This study analysed the environmental impact of different agricultural commodities across the life cycle, including beef and chicken meat, and dairy milk. The environmental impacts included were GHG emissions, acidification (partially captured by air pollutants), eutrophication (water pollutants), pesticide application (soil pollutants) and land use, amongst others. The results showed that poultry was more environmentally efficient compared to beef.

In addition, Gerber et al. (2013) studied the GHG emissions of livestock using the Global Livestock Environmental Assessment Model (GLEAM), and arrived at similar conclusions: GHG emissions per kilogram of protein generated are lower for chicken meat than for dairy milk and beef. Similar findings were provided by de Vries and Boer (2010), in which the environmental impact of several livestock products was determined, again using a life-cycle approach. According to the study, beef was the commodity with the highest impact per kilogram of protein for GHG emissions and land use. Poultry meat and dairy milk were found to perform similary for GHG emissions and land use, with the range of intensities overlapping for these commodities. Those findings are in line with the result of the top-down analysis, which shows that on average, natural capital intensities for beef are much higher than that of poultry meat and dairy milk.

An important consideration to take into account is that even if beef has a higher impact on natural capital, ruminants are able to digest non-human edible products and therefore allow animal production to happen on land that is not suitable for arable crop production. Gill et al. (2010) show that if the human edibility of the feed is taken into account, the order between poultry meat, milk and beef can change. For example, if expressed per MJ of edible product, milk emits fewer greenhouse gases than poultry. Furthermore, within one species the order of intensities can change, as Gill et al. (2010) show in their comparison of dairy systems.

Figure 3.2 shows that the natural capital intensity profile of beef and milk production is similar. For the two cattle-related sectors, land use is the most material impact followed by GHG emissions. In the case of beef, when considering all producing countries, land-use change accounts on average for $72 \%$ of the natural capital intensity, with GHG emissions contributing $20 \%$. In the case of dairy production, $62 \%$ of the impact is derived from land-use change, followed by $22 \%$ due to GHG emissions. Land use for beef and milk production is high when compared to poultry.

As mentioned in FAO (2006), the area of land used by ruminants is in general substantial, in particular with extensive grazing farming systems. In addition, extensive grazing is often practised on marginal

18 Indonesia has a high presence of backyard poultry farms, and under these systems only few farmers acquire feed from feed-mill enterprises, as household waste is often used to feed poultry (Sumiarto and Arafin, 2008). As a result, purchased feed (which is captured in the supply chain) is lower compared to other countries. The top-down approach does not take this into account, because there is no differentiation between farming systems, and this can lead to overestimating Indonesian natural capital intensity. 
lands, with poor conditions and low productivity (Suttie et al., 2005). However, land use for dairy is lower than for beef due in part to less reliance on pasture as feed (FiBL, 2012). On the other hand, GHG emissions for beef and dairy production are mainly associated with direct operations and the main source of emissions is methane from ruminant enteric fermentation. For poultry production, $39 \%$ of the total impact is associated with GHG emissions and $36 \%$ with land-use change.

Impacts due to water pollution, water consumption and soil pollutants appear as immaterial for the three sectors when compared to the other impacts. On average for all producing countries, water pollution, water consumption and soil pollutants contribute in total less than $5 \%$ of the natural capital intensity for the three livestock sectors.

\subsubsection{Poultry meat production}

Natural capital costs for poultry production at a global scale are provided in figure 3.4. Those include the top-five contributing countries to the natural capital cost of the sector worldwide. Production quantities are provided in figure 3.3, as the production level is a key parameter contributing to the absolute cost. Indonesia is a hotspot as it appears within the top-five contributors worldwide, which is why this country was selected as part of the poultry snapshots.

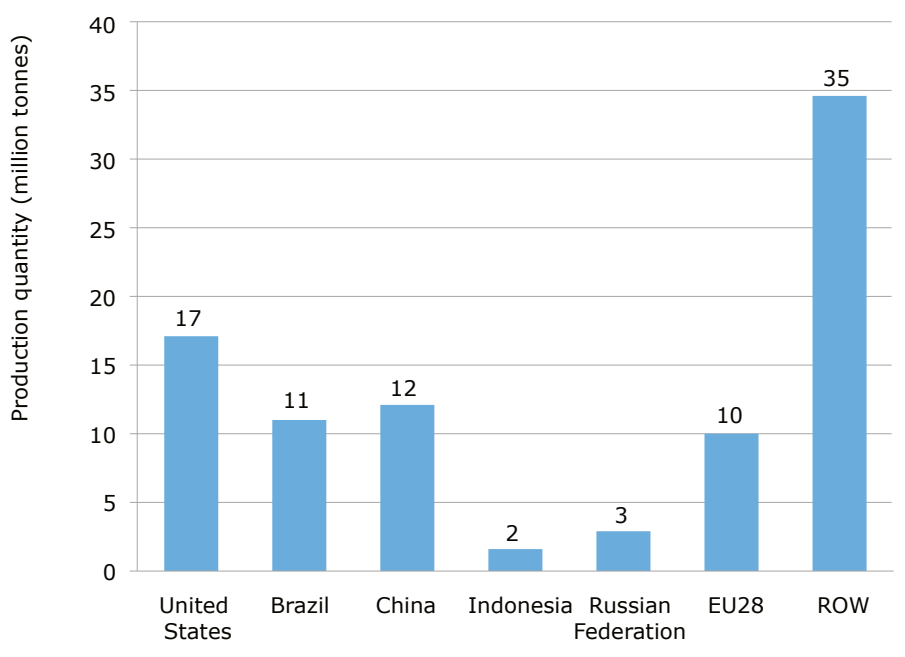

Figure 3.3 Poultry meat production for the top-five contributing countries, the EU28 and the rest of the world (in million tonnes of ready-to-cook weight)

The top-five contributing countries account for $43 \%$ of the global natural capital cost of poultry production. The United States, Brazil and China are the largest contributors, and this is mainly driven by high production quantities. These countries are the three largest poultry meat producers worldwide (FAO, $2015 a)$. The EU28 contributes to $11 \%$ of the cost of poultry production worldwide, which is comparable to Brazil and China. The EU28 has a natural capital intensity 5\% lower than the world average. The percentage reduction between world average and EU is less significant when compared to cattle, as poultry production systems are more similar globally than cattle systems. For example, the difference in environmental impact between extensive and intensive cattle production systems is very significant.

Among the top-five poultry contributing countries, an average of $27 \%$ of the natural capital cost is associated with the farming operations, with the remaining $73 \%$ associated with the supply chain. The costs from direct operations are mainly associated with greenhouse gas emissions while supply chain costs are mainly associated with the land-use change required to grow feed for poultry.

The natural capital intensity for each of the top-five contributing countries and the EU in the case of poultry, and the proportion of the intensity associated with each type of natural capital impact is shown in figure 3.4. A comparison to the world average natural capital intensity is also provided in the figure. 


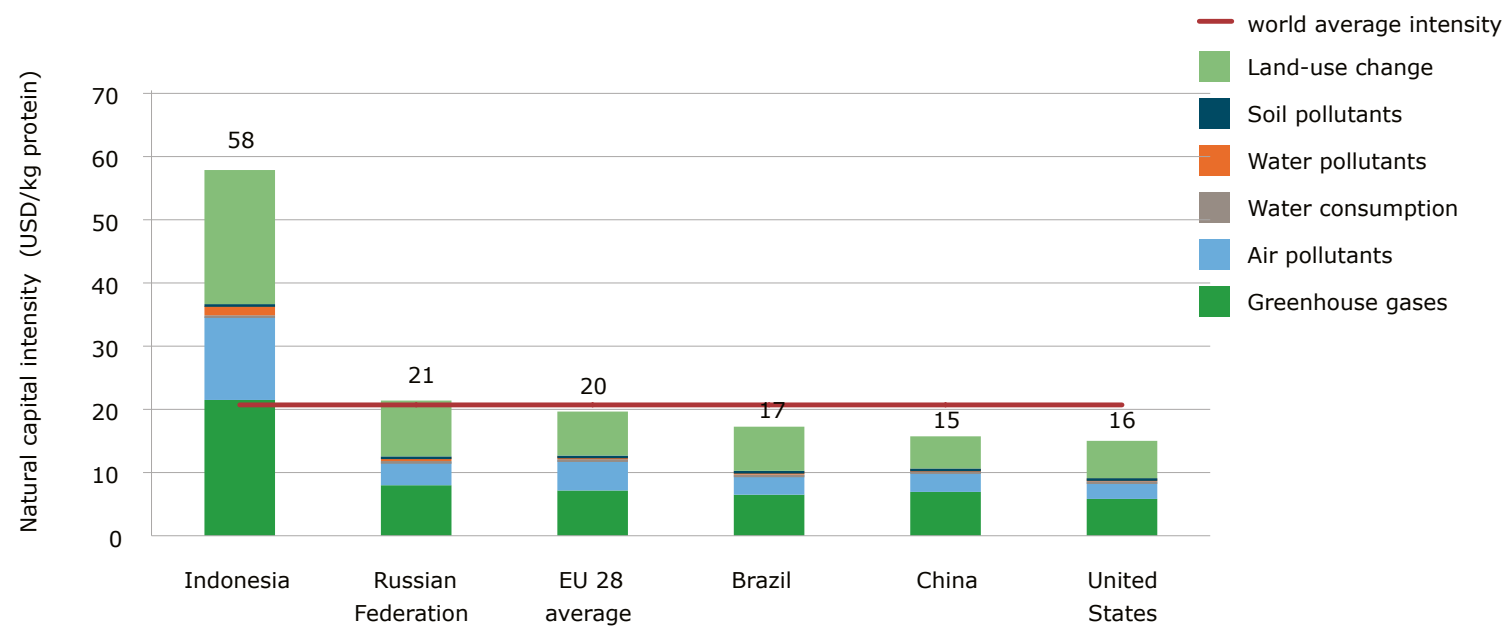

Figure 3.4 Natural capital intensity split by the type of natural capital impact of poultry production for the top-five contributing countries (in US\$/kg protein)

Indonesia is the country with the highest natural capital intensity in terms of poultry production. This is partly due to less efficient production systems, which release higher GHG emissions per kilogram of protein produced. According to FAO (2015c), GHG emissions associated with manure management from broilers in Indonesia are 1.8 times higher than the global average. The most typical poultry production systems in Indonesia are backyard systems and commercial farms (Sumiarto and Arifin, 2008). Backyard systems produce much higher manure N2O emissions than commercial systems (MacLeod et al., 2013). This is due to a range of factors, including higher feed conversion ratios, higher nitrogen excretion per kilogram of protein produced (due to higher nitrogen intake and lower nitrogen retention) and the herd structure (lower fertility rates, and higher mortality rates due to diseases and predation). The higher share of backyard production systems in Indonesia - when compared to other countries - results in higher GHG emissions.

It should be noted that as opposed to beef production, most of the impacts from poultry production come from the supply chain. Trucost's indirect EEIO model, which quantifies supply chain impacts, employs global averages to estimate the quantity of resources used or of pollutants emitted per million dollars of revenue generated (for more information, see Trucost, 2016). This implies that countries with higher producer prices will have a greater impact on natural capital. Indonesia is one of the countries with the highest producer price for chicken meat (FAO, 2015b) and this can lead to the overestimation of the supply chain impacts of poultry in Indonesia.

In addition, as mentioned above, Indonesia has a high presence of backyard poultry farms, and under these systems only a low number of farmers acquire feed from feed-mill enterprises, because household waste is mainly used to feed poultry (Sumiarto and Arafin, 2008). As a result, there is less purchased feed (captured in the supply chain) in Indonesia compared to other countries, and this fact can also contribute to overestimating the natural capital intensity for poultry meat in this country.

Table 3.4 highlights key parameters for poultry meat production, such as the top-five countries contributing to the natural capital impact of the sector worldwide, the average contribution of operational and supply chain impacts to the natural capital intensity, and the average contribution of each impact to the natural capital intensity for those five countries. 


\section{Table 3.4 Natural capital parameters for poultry meat production for the top-five contri- buting countries}

\begin{tabular}{lll}
$\begin{array}{ll}\text { PARAMETER } \\
\text { Top-5 countries }\end{array}$ & $\begin{array}{l}\text { POULTRY MEAT PRODUCTION } \\
\text { Operational versus supply chain (\%) }\end{array}$ & $\begin{array}{l}\text { Indonesia, Russian Federation, } \\
\text { Brazil, United States, China }\end{array}$ \\
\hline Natural capital intensity (\%) & Greenhouse gases & $27 \%$ vs $73 \%$ \\
\cline { 2 - 3 } & Air pollutants & $40 \%$ \\
\cline { 2 - 3 } & Water consumption & $19 \%$ \\
\cline { 2 - 3 } & Water pollutants & $<1 \%$ \\
\cline { 2 - 3 } & Soil pollutants & $3 \%$ \\
\cline { 2 - 2 } & Land-use change & $38 \%$ \\
\hline
\end{tabular}

As shown in table 3.4 , on average $40 \%$ of the impact from poultry production is related to greenhouse emissions, with $38 \%$ of the impact from land-use change and $19 \%$ from air pollutants. In addition, the supply chain impacts for poultry account for $73 \%$ of the natural capital intensity, with the remaining $27 \%$ occurring in the direct operations. The fact that the supply chain has a bigger impact on the sector is partly because the operational impacts of poultry production are lower compared to beef and dairy. This is due to a lack of GHG emissions from enteric fermentation and the relatively low land use required to raise chicken, compared to cattle production (both beef and dairy). On the other hand, higher reliance on off-farm feed crops results in higher supply chain impacts for poultry.

\subsubsection{Beef production}

Figure 3.5 shows the quantities produced of the top-five contributing countries, EU28 countries and the rest of the world for beef production. Brazil is a country that was selected as part of the snapshot analysis on beef production, and this high-level assessment shows that this country is a key contributor to the impact of the sector worldwide. A better understanding of specific faming systems of beef production in Brazil and its implications for natural capital will be provided in the snapshot analysis.

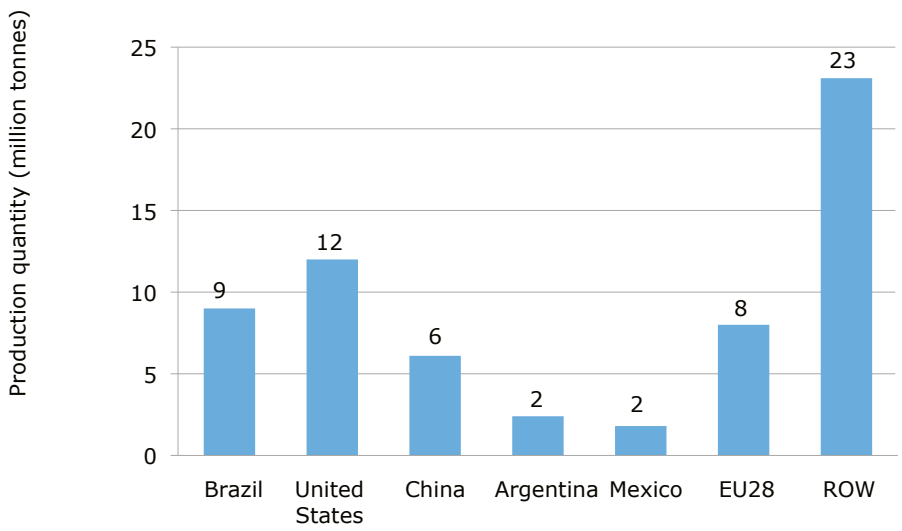

Figure 3.5 Beef production for the top-five contributing countries, the EU28 and the rest of the world (in million tonnes dressed carcass weight)

The top-five beef contributing countries (Brazil, United States, China, Argentina and Mexico) account for $50 \%$ of the natural capital cost worldwide. Brazil is the largest contributor to the impact of beef production due to a combination of high production quantities (it is the second-largest producer worldwide) and high natural capital intensity. By contrast, the EU28 contributes $8 \%$ of the total natural capital cost of beef cattle production worldwide and has a natural capital intensity $39 \%$ lower than the global average. 
This is due to low GHG emissions and land-use change costs of beef stocks in European countries. Low land use intensities in Europe can be explained by less common use of extensive grazing systems compared to Latin American countries such as Brazil or Argentina (Deblitz and Ostrowski, 2004; Ferraz and de Felicio, 2010). Furthermore, the average Ecosystem Service Value per hectare of land converted to beef production is lower in Europe (US $\$ 495$ per hectare) than in Brazil (US $\$ 1,837$ per hectare) or Argentina (US\$811 per hectare), resulting in lower overall land-use change costs in European countries (de Groot et al., 2012; Olson et al., 2001). Low GHG intensities can be explained as Europe is characterized by a high percentage of beef coming from dairy production systems, a high efficiency in pure beef production and a higher digestibility of the cattle's ration (Opio et al., 2013). In industrialized countries the feed ration mainly consists of high-quality roughages and concentrates, which have lower GHG emissions (ibid).

For beef production, the natural capital intensity for the top-five contributing countries and the EU, and the proportion of the intensity associated with each natural capital impact is shown in figure 3.6.

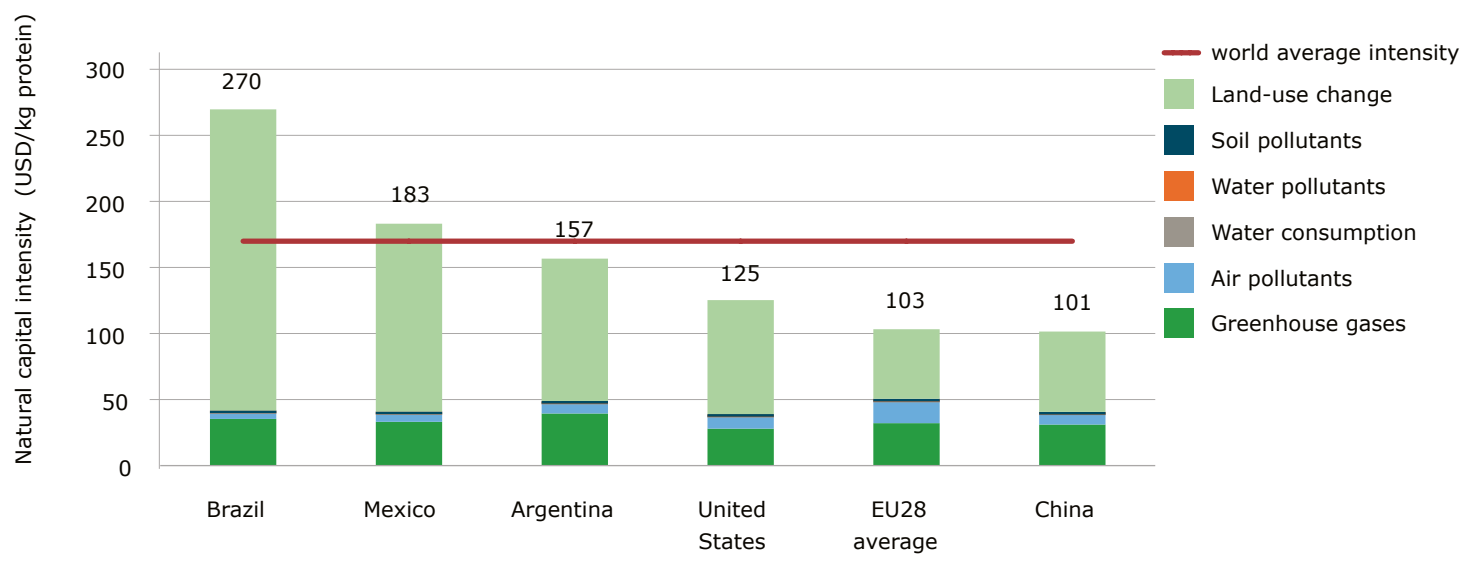

Figure 3.6 Natural capital intensity split by natural capital impact of beef production for the top five contributing countries (in US $\$ / \mathrm{kg}$ protein)

The natural capital intensity of beef production follows a similar pattern for each of the producers shown in figure 3.6. Land-use change is the most material impact, followed by GHG emissions. Amongst those countries, the variation of GHG emissions is not very significant, though land-use intensity varies substantially from Brazil to China. When compared to the other five key contributors, intense land use occurs in Brazil for beef production due to a combination of high land-use requirements for cattle ranching and the displacement of highly valuable ecosystems. Similar findings were reported in the Trucost report commissioned by TEEB 'Natural Capital at Risk: the Top 100 Externalities of Business' (Trucost, 2013), which analysed the impact of different sectors in different regions worldwide, and beef cattle ranching in Brazil appeared as an environmental hotspot due to land-use change. Brazil's strict land-use requirements are due to its reliance on an extensive pastoral production system (Ferraz and de Felicio, 2010). In addition, according to Olson et al. (2001), the predominant pristine ecosystem in the country is tropical forest, and tropical forests are a highly valuable ecosystem as they provide a wide range of ecosystem services (de Groot et al., 2012). Example of ecosystem services provided by tropical forests are medicinal resources, climate regulation and regulation of water flows (ibid). In particular, the average Ecosystem Service Value lost per hectare converted to beef production is in the top quartile of all countries, at US\$1,837 per hectare.

Table 3.5 compiles the main parameters for beef production in terms of key countries, the average split of operational and supply chain impacts, and the average contribution of each natural capital impact to the intensity profile for those locations. 


\section{Table 3.5 Natural capital parameters for beef production for the top-five contributing countries}

\begin{tabular}{lll}
$\begin{array}{ll}\text { PARAMETER } \\
\text { Top-5 countries }\end{array}$ & $\begin{array}{l}\text { BEEF PRODUCTION } \\
\text { Brazil, Mexico, Argentina, United States, } \\
\text { China }\end{array}$ \\
\hline Operational versus supply chain impacts $(\%)$ & $78 \%$ vs $22 \%$ \\
\hline Natural capital intensity $(\%)$ & Greenhouse gases & $21 \%$ \\
\cline { 2 - 3 } & Air pollutants & $6 \%$ \\
\hline Water consumption & $<1 \%$ \\
\hline Water pollutants & $<1 \%$ \\
\hline & Soil pollutants & $<1 \%$ \\
\hline & Land-use change & $72 \%$ \\
\hline
\end{tabular}

As table 3.5 shows, on average for the five-top contributing countries, land-use change contributes $72 \%$ of the natural capital impact. GHG emissions contribute to $21 \%$ of the total impact. When comparing impacts across the supply chain, on average $78 \%$ of the impact occurs within direct operations, with $22 \%$ occurring in the supply chain. This is because GHG emissions and land-use impacts, which are key contributors to the natural capital impact, occur mainly in the direct operations.

\subsubsection{Dairy milk production}

Figure 3.7 shows the dairy milk production for the top-five contributing countries, EU28 and the rest of the world. Regarding dairy systems, India appears to be a key contributor to the natural capital cost worldwide, and it was selected to be analysed at a granular level. The large quantities of milk production in India, which is the second producer worldwide according to FAO (2015a), result in this country being a hotspot in terms of natural capital costs.

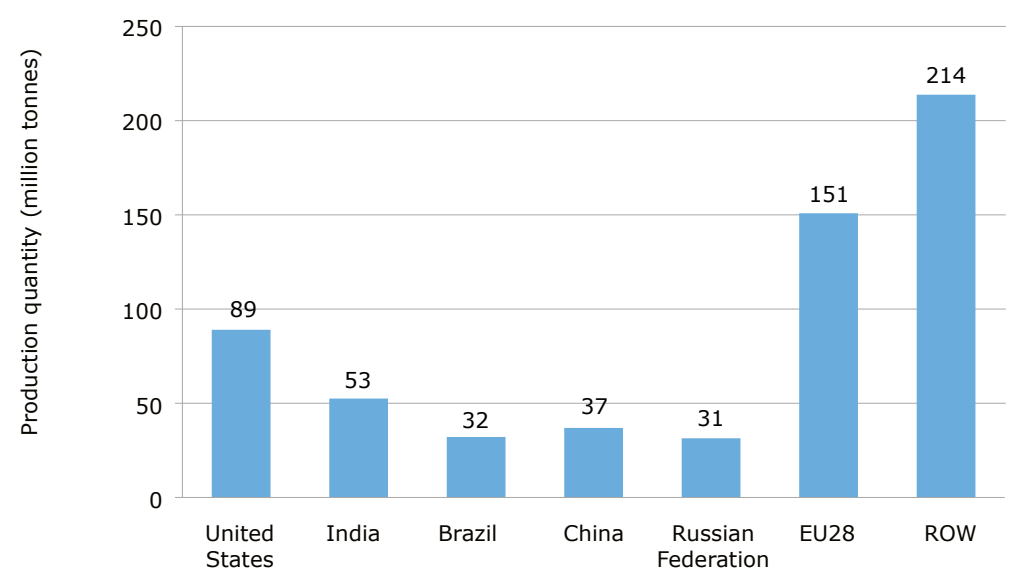

Figure 3.7 Dairy milk production for the top-five contributing countries, the EU28 and the rest of the world (in million tonnes of whole fresh milk)

The top-five dairy-contributing countries account for $39 \%$ of the total natural capital cost. The USA is the largest contributor to the natural capital cost of dairy due to high production quantities, as it is the largest milk producer worldwide (FAO, 2015a). The USA dairy sector relies primarily on intensive production systems (confined systems, with conserved fodder and relatively high percentages of compound feeds) and Holstein cows that are genetically optimized for milk production, in contrast to the dual optimization for meat and milk practiced in some other countries (EPA, 2015). Milk is produced in all 50 
states of the USA and is second only to beef, and equal to corn, in terms of total farm value (USDA, 2012).

EU countries have an average natural capital intensity $24 \%$ lower than the global average. Dairy production has lower emission intensities in systems that have high productivity (Gerber et al., 2013). Thus, similar to beef production, lower GHG intensities in EU28 countries can be explained by high feed digestibility and more efficient herd management practices, which are characteristic of high productivity systems (ibid).

Figure 3.8 presents the natural capital intensity of the EU and key dairy milk producing countries compared to the world average natural capital intensity.

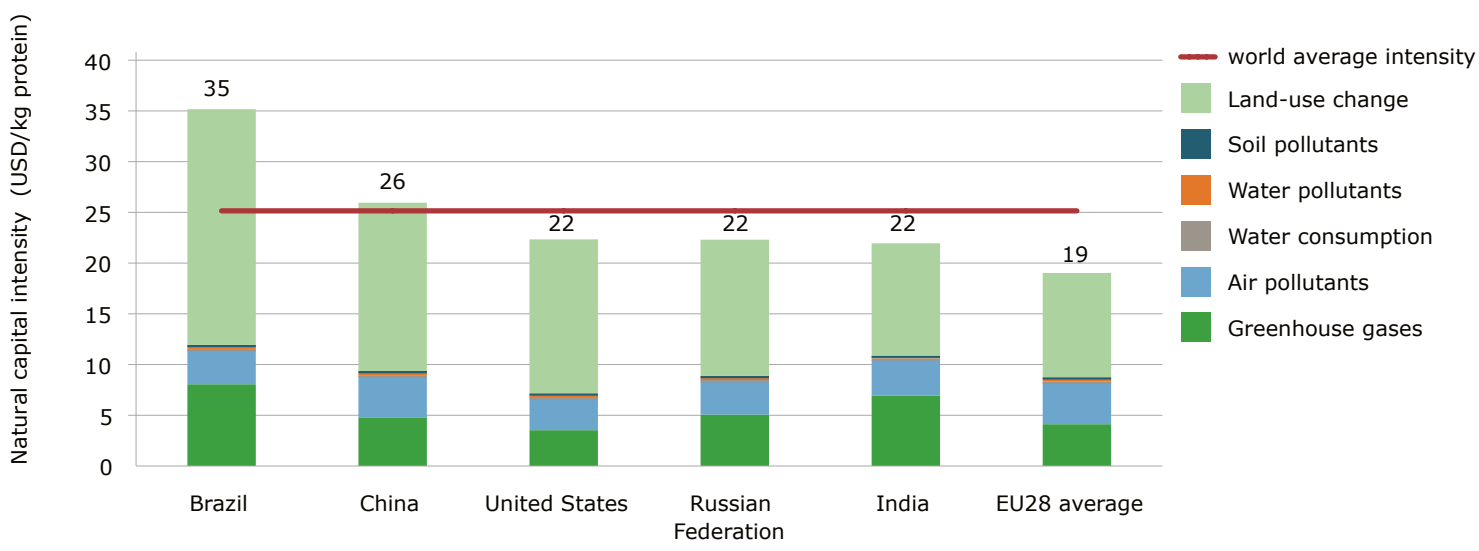

Figure 3.8 Natural capital intensity split by natural capital impact of dairy milk production for the top-five contributing countries (in US\$/kg protein)

Similar to beef production, Brazil is the country with the highest natural capital intensity amongst the five contributing countries. This is mainly because the country exhibits the highest land-use intensity and the highest GHG emissions per unit of protein production amongst those countries. Land-use intensity for milk production is high in Brazil due to the displacement of highly valuable ecosystems present in the country. High GHG intensities are partly due to larger methane emissions (from enteric fermentation) per kilogram of protein produced compared to the remaining four key contributing countries (FAO, 2015b). Methane emissions are influenced by a range of factors including the use of low-quality feed (low digestibility feed generates more methane emissions), low productivity (feed is used for animal maintenance and not for production) and the herd structure (higher number of replacement animals that do not produce milk but contribute to the emission of methane) (Opio et al., 2013). Dairy production in Brazil is predominantly based on grazing systems with smaller contributions from confined and semi-confined systems (New Zealand Trade and Enterprise, 2010). The high proportion of grazing systems can explain the high land-use requirements for dairy in Brazil.

Table 3.6 highlights key parameters for dairy milk production, such as the top-five countries contributing to the natural capital impact of dairy milk production worldwide, the average contribution of operational and supply chain impacts to the natural capital intensity, and the average contribution of each impact to the natural capital intensity for the top-five countries. 


\section{Table 3.6 Natural capital parameters for dairy milk production for the top five contributing countries}

\begin{tabular}{lll} 
Parameter & & Dairy milk production \\
Top-5 countries & & $\begin{array}{l}\text { Brazil, China, Russian Federation, } \\
\text { United States, India }\end{array}$ \\
\hline $\begin{array}{l}\text { Operational versus supply chain } \\
\text { impacts (\%) }\end{array}$ & Greenhouse gases & $66 \%$ vs $34 \%$ \\
\hline Natural capital intensity (\%) & Air pollutants & $22 \%$ \\
\hline & Water consumption & $14 \%$ \\
\hline & Water pollutants & $<1 \%$ \\
\hline & Soil pollutants & $1 \%$ \\
\hline & Land-use change & $<1 \%$ \\
\hline
\end{tabular}

As shown in table 3.6, land-use change in the top-five countries contributes $62 \%$ of the natural capital impact of dairy production, followed by GHG emissions at $22 \%$. When analysing the impacts across the value chain, on average $66 \%$ of the impact is found in the direct operations and $34 \%$ in the supply chain. GHG emissions per kilogram of protein are lower for dairy than beef since dairy cattle produce higher overall quantities of protein throughout their lifespan, while the inputs required are comparable to beef (Opio et al., 2013).

\subsection{Biodiversity and livestock production systems}

Habitat change and climate change are considered among the most prominent threats to biodiversity worldwide (Alkemade et al., 2009; Parmesan and Yohe, 2003; Sala et al., 2000; Warren et al., 2011). and are likely to alter ecosystem processes and reduce ecosystem resilience to additional or continued negative pressures (Chapin III et al., 2000). Food production is the economic sector with the strongest impact on biodiversity, contributing 60\%-70\% of total global biodiversity loss (Kok and Alkemade, 2014). Newbold et al. (2015) showed that local urbanization has the strongest negative impacts on biodiversity, closely followed by the expansion and intensification of pasture and cropland areas.

Based on an earlier literature review (Reid et al., 2010), and also illustrated in this study, it appears that livestock production systems primarily have negative impacts on biodiversity. These negative impacts include direct impacts on biodiversity associated with (heavier) grazing, trampling and defecation. Yet the predominant biodiversity impacts are indirect, resulting from habitat conversion to create (intense) pastures and cropland for feed, and from emissions of greenhouse gases (Reid et al., 2010).

Yet there are positive impacts as well, such as the maintenance of permanent grasslands, which in terms of biodiversity are among the richest habitats in some regions. There can be a continuous gradient between negative and positive impacts on biodiversity, which are strongly determined by management practices (LEAP, 2015). With current practices, however, the negative effects dominate on a global scale.

\subsection{Animal and human health: A Global One Health}

Animal production and human health are related to each other in multiple ways:

- At a global scale, livestock products are important providers of animal protein and essential micronutrients. More than three quarters of the world's undernourished people live in rural areas, and most of them depend on agriculture, including livestock for their livelihoods (FAO, 2009a). At least this is true as long as the quantities consumed are limited. It is known that overconsumption of animal protein increases the risk of obesity, cancer and cardiovascular diseases. 
- There are human diseases related to animals, called zoonoses. There are several different vectors by which humans can be infected (blood, air, animal products). Examples of livestock-related zoonoses are Avian Flu, Salmonella, Campylobacter, E. coli, Leptospirosis, Toxoplasmosis and Q-fever. See http://www.who.int/zoonoses/en/.

- Animal health can affect the health and well-being of humans in various ways, as is illustrated in the figure below (FAO, 2009a).

- Animals and humans use the same kind of antibiotics. The frequent veterinary use of antibiotics, and especially the veterinary use of those antibiotics that are critically important to human health care, increases the risks of antimicrobial resistance, e.g. ESBLs and MRSA. The danger is that in the end no antibiotics will be available to combat resistant bacteria in hospitals, for example.

- Controlling the risks of disease outbreaks and reducing endemic infectious diseases are crucial to food security, public health, climate change and biodiversity.

Figure 3.9 (FAO, 2009a) shows that in addition to the direct relation with human health there is also an indirect relation in terms of the economic risks (productivity losses, market disruptions and livelihood risks). Animal diseases have a negative impact on the income of especially poor livestock keepers and also have a strong impact on their consumption of animal products and their health.

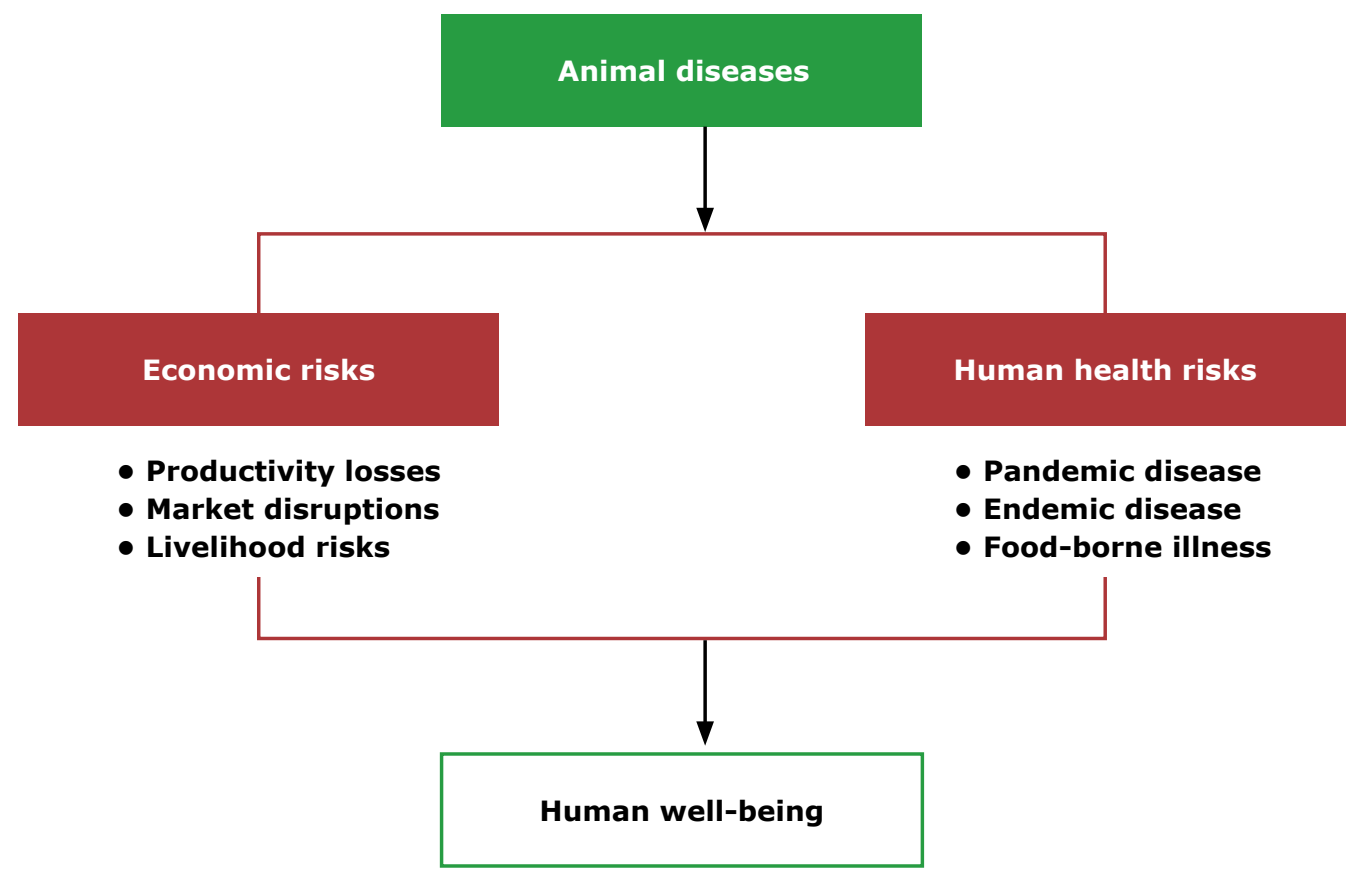

Figure 3.9 Impacts of animal diseases on human well-being

Wageningen University \& Research uses the phrase 'A Global One Health', as it reflects the interconnectedness and global nature of health care for humans, animals, plants and the environment. Many health risks can be controlled through effective interventions consisting of an adequate and varied food supply, hygiene, medicines, vaccines, vector control and crop protection. A sustainable and shared approach requires an integrated analysis of infectious diseases, with contributions from various knowledge domains (Wageningen UR, 2015b).

A set of indicators is needed to cover the overall theme and evaluate the relation between animal production systems and human health. Indicators about the health of livestock farmers including their families are scarce and absent for most countries, even in the Western world. Indicators of animal health are also scarce in many countries (indicators include death rates, the use of vaccines and the use of antibiotics, for example). Information about sick animals (frequency and severity) is more or less absent (OiE, 2015). Therefore, it is very hard to indicate and evaluate the relation between the animal production systems and human health. 
Some relations on the macro-level are clear. Intensification of animal production systems goes hand in hand with the increased use of inputs. Antibiotics is one of these inputs, and it is still being heavily used in the commercial livestock production systems. In many cases this frequent use of antibiotics hides farmers' bad management or risk averse behaviour. However, Danish and Dutch practice shows that it is possible to have intensive and high animal production without resorting to the frequent use of antibiotics (Wageningen UR, 2015a). Some organic farms in the Western world are able to reach quite high production levels per animal as well without use of antibiotics.

Health risks differ among animal species. The risks of zoonoses are lower for cattle than for poultry. Other factors, like the number of flocks/herds in a region, the number of animals per flock/herd, housing, manure management and pest control, can influence animal health and thus also exacerbate the risks to human health. In highly populated regions with a high density of livestock the emission of particulate matter might influence human health as well.

To conclude: human health is important when comparing different livestock production systems because human health is in many cases directly involved. Given the high prevalence and high severity (death of people) of zoonoses, the natural capital costs are potentially high. On the other hand, the consumption of animal protein has benefits for human health, both in the developing and the developed world.

\subsection{Key findings of the top-down approach}

\section{Natural capital costs}

- Natural capital costs express in monetary terms the impacts on natural capital that are produced by livestock systems, as a result of resource use and pollutant emissions (units in US\$). Natural capital costs include the impact of supply chain (upstream) and operational (farming) activities on six natural capital impact categories: GHG emissions, air pollutants, water consumption, water pollutants (from fertilizer application), soil pollutants (from pesticide application) and land-use change.

- The total natural capital cost of beef, dairy milk and poultry meat have been calculated by considering all producing countries, and thus represent the impacts of those sectors at a global scale. Beef production is the sector with the greatest natural capital cost worldwide. The total natural capital cost of beef production (which is US\$1.5 trillion) is three times that of dairy milk production (US $\$ 0.5$ trillion) and approximately six times higher than that of poultry meat production (US\$0.26 trillion).

- The contribution of direct operations to the total natural capital cost is approximately $78 \%$ for beef, $65 \%$ for dairy milk and $29 \%$ for poultry meat when considering all producing countries. Thus for beef production, natural capital costs are mainly associated with the direct operations, while for poultry they are mainly associated with the upstream supply chain. This can be explained by the lack of enteric fermentation, the low land-use requirements of poultry, which are associated with direct operations, and the higher use of feed cultivated off-farm and thus acquired as part of supply chain activities. For dairy milk production the split between direct operations and supply chain impacts is similar. Compared to beef, there are more impacts in the supply chain as dairy systems rely to a greater extent on purchased feed than beef systems, which has a greater impact on the supply chain.

- The share of the total natural capital cost for the top-five contributing countries is $50 \%$ for beef (Brazil, US, China, Argentina and Mexico), 39\% for dairy milk (US, India, Brazil, China, Russian Federation), and $43 \%$ for poultry (USA, Brazil, China, Indonesia, Russian Federation). EU28 contributes $8 \%, 19 \%$ and $11 \%$ of the total natural capital cost of beef, dairy milk and poultry production respectively.

- Variation in country-level natural capital costs can be explained by:

- The total number of animals under production

- Efficiency of livestock production systems (resource use or emissions per tonne of production)

- Natural capital valuation coefficients (for example, the value of the ecosystems present in the country) 


\section{Natural capital intensities}

- Natural capital intensities express the natural capital cost per protein content (units in $\$ / \mathrm{kg}$ protein). This metric makes it possible to identify the commodity that provides the greatest amount of protein with the lowest impact on natural capital.

- When determining the average natural capital intensity considering all producing countries for the three commodities, it was found that beef has the highest associated natural capital intensity and poultry meat the lowest (US $\$ 170 / \mathrm{kg}$ of animal protein versus US $\$ 21 / \mathrm{kg}$ of animal protein). Lower GHG emissions and land-use change per kilogram of protein are associated with poultry production as a result of low feed conversion rates, and the lack of enteric fermentation for monogastrics.

- The average natural capital intensity of EU countries is significantly lower than the global average in the case of beef and dairy milk. This is partly due to higher efficiencies in the production system, such as higher feed digestibility and more efficient herd management practices for cattle.

\section{Types of natural capital impacts}

- For beef and dairy milk, land-use change is the most important natural capital impact (contributing $72 \%$ and $62 \%$ of the natural capital intensity, respectively) followed by greenhouse gas emissions ( $20 \%$ and $22 \%$, respectively) when considering all producing countries. In the case of poultry meat, GHG emissions represents the largest natural capital impact (39\%), followed by land-use change (36\%).

- The contribution of water pollution, water consumption and soil pollutants in total is less than $5 \%$ of the natural capital intensity on average for all species.

\section{Benefits}

- The provision of food represents one of the most significant benefits to society provided by livestock. Furthermore, livestock systems can enhance a wide range of regulating, supporting and cultural services. Some examples include: soil carbon sequestration (regulating service); connecting habitats for plant species through seed dispersal in seasonal grazing systems (supporting service); and the enrichment of cultural identity through the role of livestock in social and spiritual activities (cultural service).

\section{Biodiversity impacts and dependencies of livestock production}

- Livestock production affects biodiversity in many different ways, which, depending on local conditions, differ in type and magnitude of impact. These impacts are predominantly negative, although some positive effects exist as well, especially in extensive livestock grazing systems, such as in pastoralist rangelands protecting the rangelands from being converted to even more damaging cropland production. Yet locally, management practices may be applied to alleviate the negative impacts or restore biodiversity.

\section{Animal and human health}

- Livestock production systems have a huge direct and indirect impact on human health, including benefits and positive and negative externalities. Animal protein is an important part of the human diet. Zoonoses endanger human health, as can the use of antibiotics in animal production systems. Diseases from poultry production have a bigger impact on human health than cattle. So the gap between species in natural capital costs is in reality smaller than estimated with the present valuation models, which do not take into account the animal and human health factor.

- For now, there are no good indicators to quantify the relation between animal diseases and human health. This is partly due to a lack of knowledge and data in both the developed and developing world. 


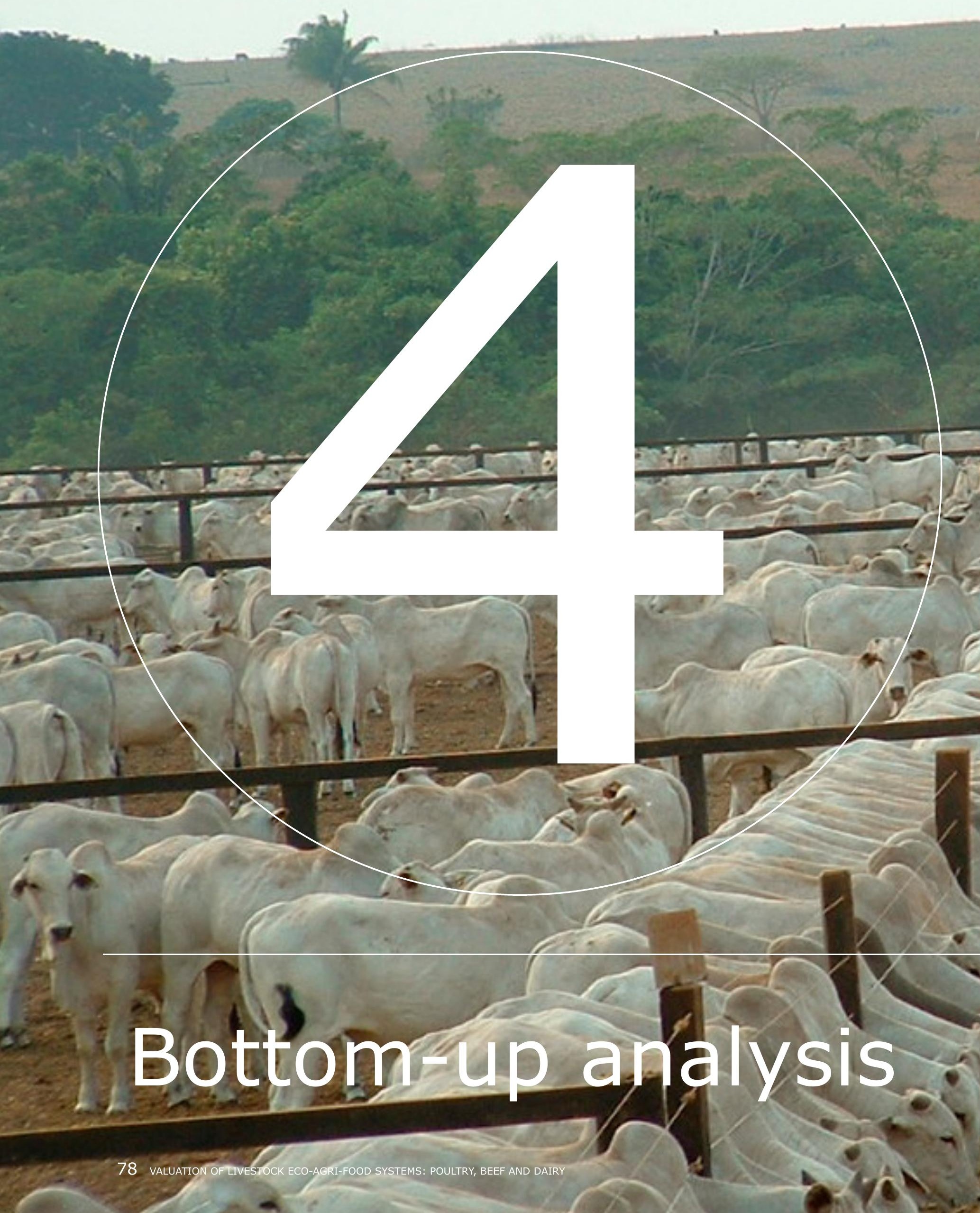


4.1

Snapshot descriptions

$>$

1 . a v

4.1.1 / Snapshot 1 Tanzania backyard poultry

4.1.4 / Snapshot 4 Tanzania pastoralist cattle

4.1.7 / Snapshot 7 Tanzania dairy mixed feeding

$>$ 4.1.2 / Snapshot 2 farm broilers

$>$ 5 / Snapshot 5 India pastoralist buffaloes

4.1.8 / Snapshot 8 India dairy mixed feeding
$>$ 4.1.3 / Snapshot 3 The Netherlands industrial broilers

$>$

4.1.6 / Snapshot 6 Brazil

$>$

4.1.9 / Snapshot 9

The Netherlands dairy specialized

4.1.10 / Snapshot 10 Indonesia dairy mixed $\nabla$ feeding

\section{2}

Assessment and valuation of the snapshots

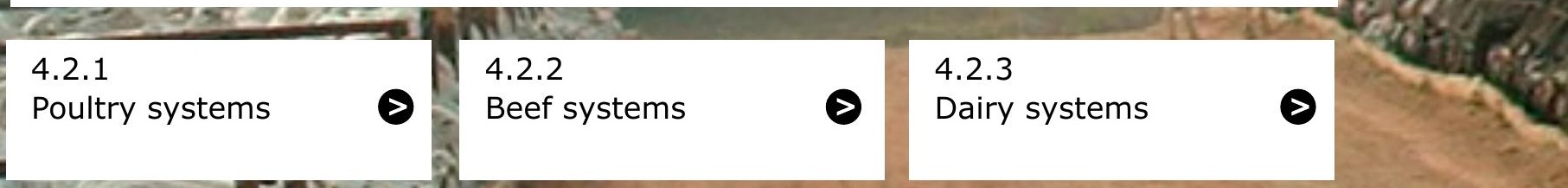

\section{3}

Bottom-up quantitative assessment and valuation at snapshot level

$\begin{array}{lll}\begin{array}{l}4.3 .1 \\ \text { Greenhouse gases }\end{array} & \boldsymbol{\nabla} & \begin{array}{l}4.3 .2 \\ \text { Water pollution }\end{array}\end{array}$

4.4

General results bottom-up valuation

4.3 .3

Quantification of land occupation

\section{5}

Key findings bottom-up analysis 


\section{Bottom-up analysis}

This chapter presents ten livestock snapshots, and the results of the bottom-up assessment of these ten snapshots. After introducing the snapshots, we present an overall quantitative assessment of the snapshots. For some indicators, we were able to present quantitative and monetary values. The assessment and valuation of impacts and dependencies of various production systems facilitates rational comparisons of policy choices when trade-offs exist between food production systems with their own impacts and dependencies upon ecosystems. A bottom-up approach is mainly based on local or regional data and can provide insightful context and granularity required to aid decision-makers at all levels with complex policy choices.

The quantitative and valuation analysis presents the natural capital costs in terms of greenhouse gas (GHG) emissions and water pollution. We then quantified the land footprint of livestock production and looked specifically at its impact on biodiversity. Last, the results reflect the degree of dependency of animal husbandry on ecosystems for the provision of blue water. Finally, we summarize the main findings.

Monetizing these impacts across different animal husbandry systems provides an opportunity to assess relative magnitudes and compare approaches, both within particular geographies, between different geographies, and over time. Monetization facilitates comparisons between different impacts, and also makes it possible to compare economic indicators such as product retail prices.

The starting point is a broad spectrum comparison across the entire livestock system in question that looks at the (monetary) value of its impact or dependency on natural capital. However, a comparison between production systems is only meaningful if the systems are substitutable to a certain degree, because then it can help policy-makers, farmers and consumers to better understand the differences between the alternative options that they face. That is why we were cautious about identifying when systems are sufficiently comparable and/or substitutable, so that we could make a meaningful comparisons of valuation results.

Based on these considerations, we made the following comparisons for all issues within the scope of this quantitative assessment:

- Beef ranches: an assessment of extensive beef production in Brazil (snapshot 6), including possible variations of the systems as explained in section 4.3.1. Farmers face the choice of whether to implement certain improvements, and local policy-makers face the choice of whether to encourage such improvements.

- Pastoralist and dairy cattle: a comparison between cattle in traditional extensive systems and dairy farms, where grass and/or crop residues constitute the main source of feed, in Tanzania (snapshots 4 and 7 ) and India (snapshots 5 and 8).

- Systems able to export: Consumers face ongoing choices as to which products to buy, and policy-makers from importing countries face the problem of whether to encourage certain imports or local production systems. Therefore, it is interesting to compare the three production systems that we have studied, which can supply animal proteins to international markets: the industrial broiler system (snapshot 3), intensive dairy production in a mixed farm as practiced in the Netherlands (snapshot 9) and beef production by grazing with feedlots in Brazil (snapshot 6).

\subsection{Snapshot descriptions}

\subsubsection{Snapshot 1: Tanzania backyard poultry}

Backyard or village production of poultry is the dominant global production system, in particular in developing countries in Africa and Asia. The type of chicken in backyard systems is mostly a local breeds 
that is well adapted to local circumstances. The chickens are kept free range and find their own feed. Often the birds get leftovers or food not suitable for human consumption. Housing is often limited to night shelters, and medical care is very limited. This low-input system for poultry also has a relatively low production level (in kg protein per chicken) with high death rates. The number of chickens per farm generally varies from 10 to 30 (Boki, 2000; Knueppel et al., 2009), and occasionally up to 150 chickens (Kisungwe, 2012). A flock of 25 birds typically has an output of 220 eggs and $70 \mathrm{~kg}$ of meat annually. Chickens are generally kept by the rural poor and managed by women and children.

Chickens play a vital role in households by providing an important source of high-quality nutrition, an income, as well as quick cash to pay for medicine, food, transportation or school fees, and manure. Chickens drop their manure in the backyard. Only the manure in the night shelter is collected as fertilizer for crop production. Greenhouse gases are estimated at $6.5 \mathrm{~kg} \mathrm{CO}$-eq per kg carcass weight (MacLeod et al., 2013). Chickens also play a role in social activities, religious ceremonies and the traditional treatment of diseases (Knueppel et al., 2009). Poultry cohabit with humans and have free contact with potential reservoirs of HPAI viruses, salmonella and other zoonoses.
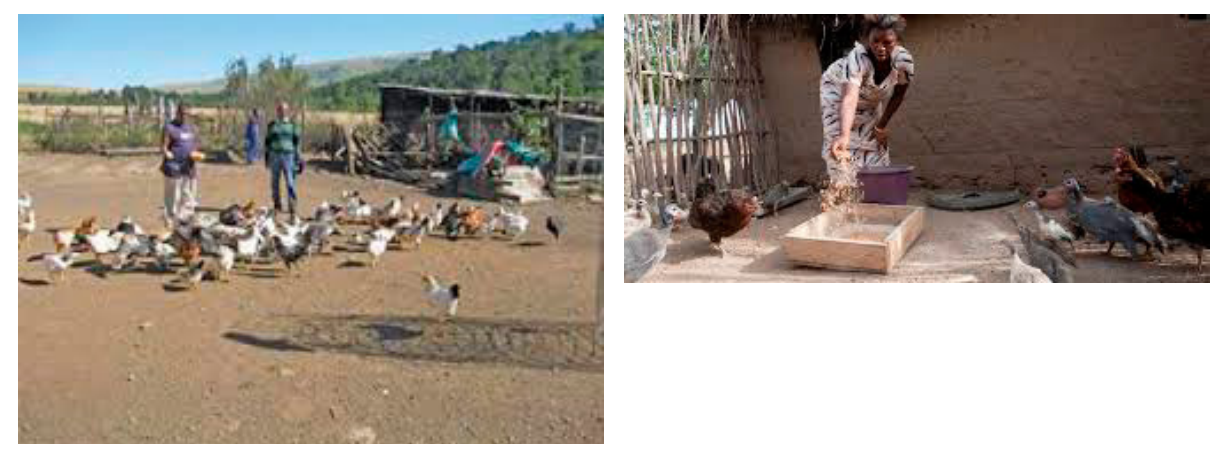

Picture 4.1 Backyard poultry keeping in rural areas in sub-Saharan Africa

\subsubsection{Snapshot 2: Indonesia family farm broilers}

The total poultry production in Indonesia in 2011 was estimated to have been 1.6 million tonnes of meat (FAO, 2015a). Poultry accounts for an estimated $62 \%$ of total domestic meat production and plays an increasingly important role in the Indonesian diet (USAID, 2013). Extensive backyard poultry systems are very common in Indonesia, as are commercial breeding farms (IFPRI, 2008). In Java, most chicken operations are extensive systems (backyard) or semi-intensive (better management practices) (FAO, 2009a).

The size of medium-scale family poultry farms ranges from 150 to 15,000 birds. Mostly commercial breeds are used in these production systems but local breeds of chicken, ducks and turkey are used as well. This type of specialized farm operates in a semi-intensive or intensive way. Day-old chickens, feed and veterinary services are sourced from supplier companies. Chickens are kept indoors in relatively simple housing systems with low investment costs. For 5,000 birds the investment is about 5,000 euros. Birds are sold to slaughterhouses at an age of 5 to 7 weeks. The live weight at slaughter ranges from 1.2 $\mathrm{kg}$ to $1.5 \mathrm{~kg}$ per bird. For a farm with a capacity of 5,000 broilers the annual production is around 32,000 birds, or $40,000 \mathrm{~kg}$ of meat. Animal health care consists of vaccination against Newcastle disease and Gumboro as well as disinfecting the shed before a new flock arrives. The breeding stock usually originates from breeding companies in the US or Europe. Most countries import grandparent stock and countries have specialized hatchery farms. The broilers are fed with industrial compound feed from a feed mill. The feed ingredients can be local or imported, and consist of energy (maize, grains) and protein (soy). The use of agro-industrial by-products in broiler feed is rare. Small amounts of antibiotics in feed are used to improve growth. The system is labour intensive compared with large-scale industrialized poultry systems (hours per unit of output). One worker, usually a family member, can take care of 5,000 animals. In addition to the value of the broilers, the dry manure from the broilers is valuable for crop production as well. Usually poultry farmers specialize and do not grow their own crops for feeding poultry (personal communication with Peter van Horne). 
Diseases like avian influenza are public health concerns. A rapid increase in the number of farms may lead to the emergence of highly pathogenic strains from a pool of low pathogenic viruses maintained in wild or domestic birds. Zoonoses like salmonella are also a risk for consumers. There have been discussions recently about the use of antibiotics in broiler production because their excessive use causes resistance (Robinson et al., 2011).
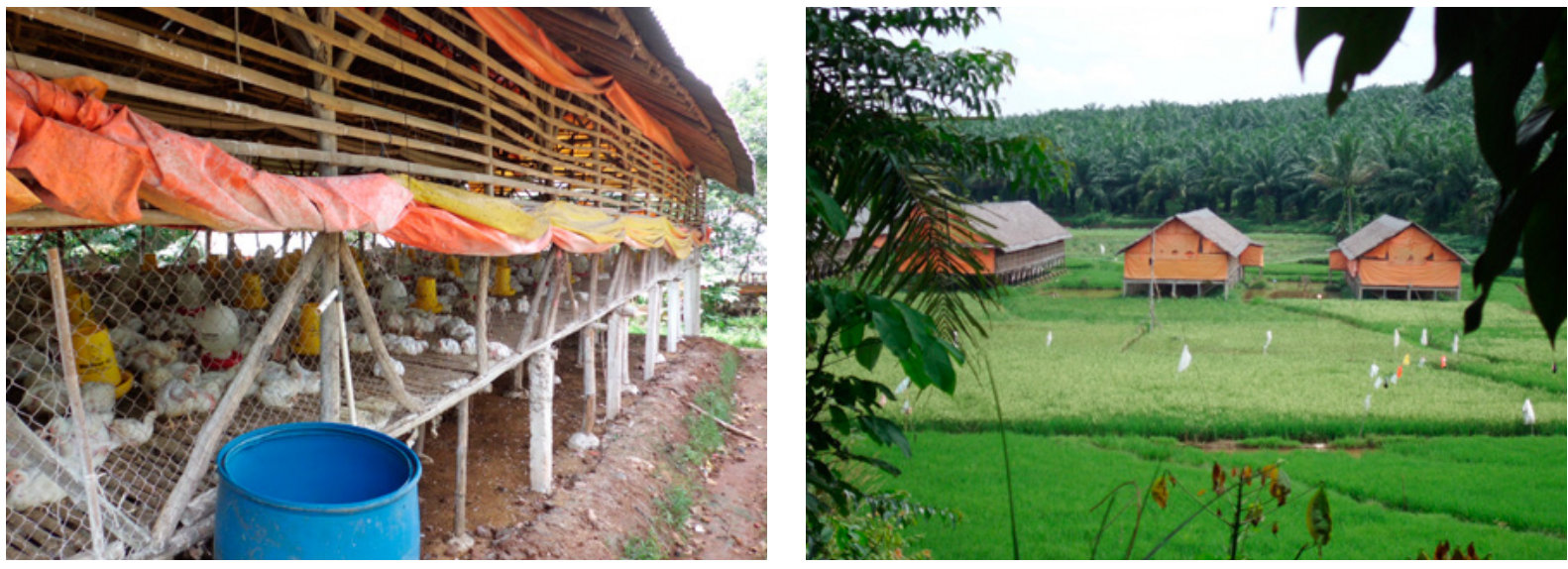

Picture 4.2 Photo example of a broiler farm in Indonesia

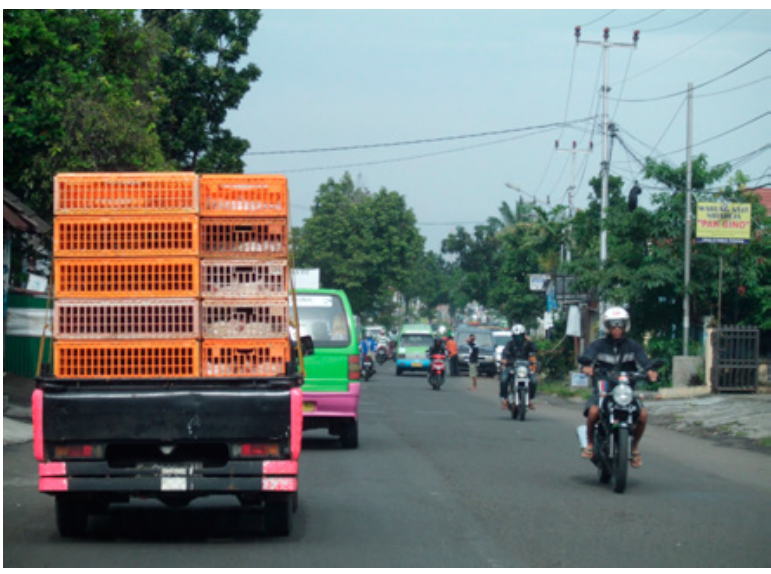

Picture 4.3 Transport of broilers from farm to slaughterhouse (Indonesia, 2013)
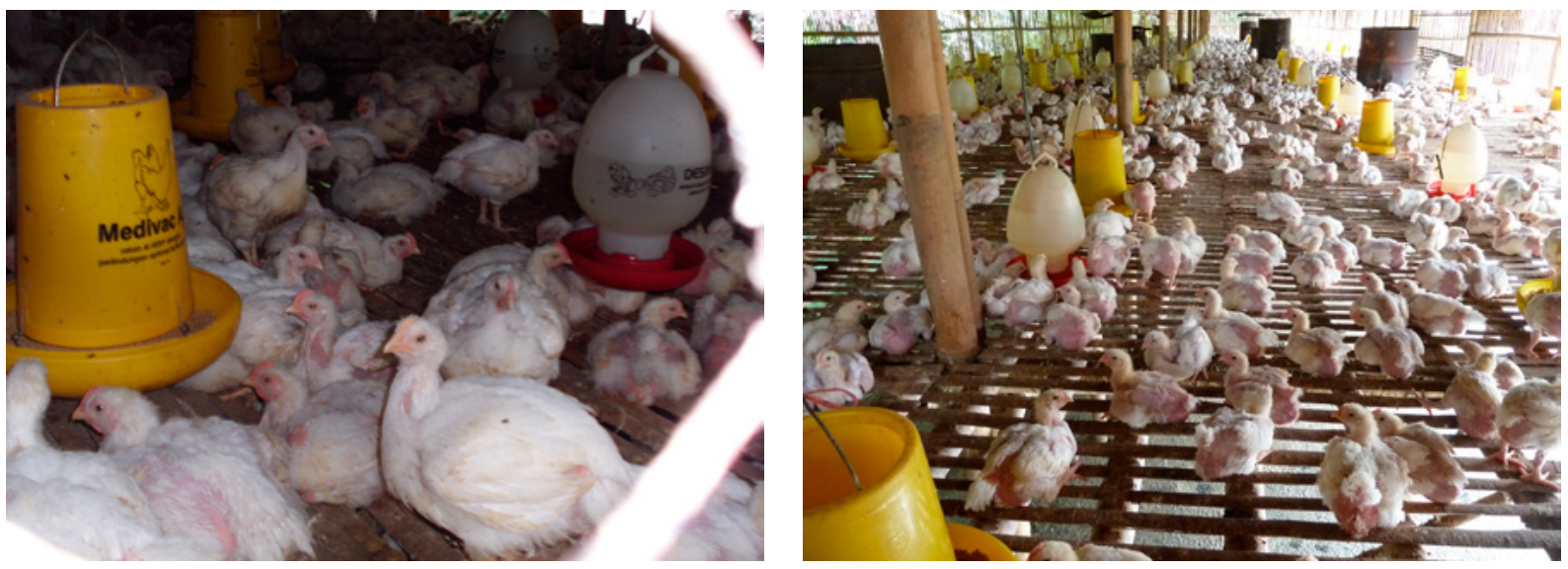

Picture 4.4 Example of feed (yellow) and water (white) equipment. Manual system 


\subsubsection{Snapshot 3: The Netherlands industrial broilers}

Industrial poultry production is the dominant system in the Netherlands. The poultry sector has grown rapidly in recent decades with total production increasing more than eightfold since the 1960s (Government of the Netherlands, n.d.). The Netherlands is the 27th producer worldwide according to Robinson et al. (2011).

Industrial broiler production systems are large-scale family farms with flocks ranging from 50,000 to 100,000 birds. Broilers are kept in modern poultry houses in groups of 20,000 to 25,000, free loose housed on litter with automated provision of water and feed (Horne and Achterbosch, 2008). All inputs, such as the birds themselves, their feed and veterinarian services are bought from supplier companies. The day-old chicks are bought from a hatchery. Feed is bought from feed mills and consists mainly of wheat and corn from Europe and soy from Brazil, Argentina and the US. Industrial systems use commercial breeds, which require optimal climate control, high-quality feed, water and good sanitation.

Investments for a capacity of 75,000 broilers are around 1.1 million US dollars. A farm with a capacity of 75,000 broilers produces 1.2 million $\mathrm{kg}$ of live weight. One worker can take care of 75,000 broilers with some help during the start and end of the production cycle (receiving the day-old chicks, catching birds and cleaning). Manure is a valuable by-product of the poultry farm mostly transported over long distances to be used as fertilizer for crop production. Part of the poultry manure is supplied to manure-burning plants producing 'green' energy. Greenhouse gas emissions are estimated at 5.2 kg $\mathrm{CO}_{2}$-eq per kg carcass weight (MacLeod et al., 2013).

Animal health care is ensured by systematic vaccination for Newcastle Disease, Infectious Bronchitis and Gumboro in combination with cleaning and disinfection after every flock (including removing all the manure) and strict bio-security management. Coccidiosis is controlled by adding anticoccidials in the broiler feed. The use of antibiotics has been reduced by more than $50 \%$ in recent years in the Netherlands. Zoonoses like avian influenza, salmonella and campylobacter are a threat to human health. According to the EU (council directive 2005/94/EC), measures need to be taken to control avian influenza by killing poultry on infected holdings and cleaning and disinfecting the holding. For salmonella, the Netherlands has adopted an integrated chain approach to decrease the prevalence of salmonella in broiler flocks. The prevalence was reduced from $12 \%$ in 2000 to 5\% in 2013 (www.agrimatie.nl).

\subsubsection{Snapshot 4: Tanzania pastoralist cattle}

Maasai households use communal pastures to graze cattle, small ruminants and donkeys. A group of households together typically owns 300 head of cattle, 50 sheep, 60 goats, chickens and dogs. Maasai keep local breeds that have adapted to the more harsh circumstances. Their own male animals are used for reproduction, and they do not use artificial insemination. Animals graze in one area for about six months during the rainy season, and overgrazing is common (Steinfeld et al., 2006). During the dry season, the household searches for other grazing land for their animals. This mobile system of seasonal and cyclical migration has been practised for decades. The family does not use inputs such as fertilizer or irrigation for grass production. During very dry years, when there is a shortage of grass, the animal are also fed with crop residues obtained from local crop farmers.

The Maasai share their grazing grounds with wildlife, and contribute to the conservation of their habitat. Milk is produced only during the rainy season, and any surplus not used for household consumption is bartered or sold. However, the surplus is often very limited. In the dry season the milk yield is very low. The Maasai generally use animal meat for their own consumption: they are slaughtered and consumed during ceremonies, offered as a dowry, and sold only when there is a need for cash. Due to harsh conditions and an occasional scarcity of feed, herd productivity is low. Typically a herd of 100 animals produces around $10,000 \mathrm{~kg}$ of milk annually and between 10,000 kg and 15,000 kg of meat. Agrotourism is very important in the areas where the Maasai graze their cattle. Some of their camps can be visited.

Inputs into this pastoral system are low: no irrigation, no fertilizers, no antibiotics (occasionally cattle are vaccinated) and no machinery. The pastoral system is labour intensive and can only be managed by an 
extended family. The nutrient cycling is at a very low level (low input and output per animal and per ha). Total $\mathrm{N}$ and $\mathrm{P}$ surpluses is assessed at $260 \mathrm{~kg}$ and $130 \mathrm{~kg} \mathrm{~N}$ and $\mathrm{P}$, respectively, assuming 1,000 ha land in use results in 260 gram $\mathrm{N}$ and 130 gram $\mathrm{P}$ per ha. With $80 \%$ home consumption, the nutrients remain in the same area, albeit concentrated on homesteads. Once every three years there is a drought and animals are fed with straw or stover. ${ }^{19}$ We are assuming that $100,000 \mathrm{~kg}$ is fed to the animals during the whole season ( $3 \mathrm{~kg}$ straw per animal per day, about 100 days), in which case the nutrient input via consumed straw is $670 \mathrm{~kg} \mathrm{~N}$ and $70 \mathrm{~kg} \mathrm{P}$ over the total herd. Nutrient balances range between $-1 \mathrm{~kg}$ and $+1 \mathrm{~kg}$ per ha per year. There will be no surplus of nutrients going into the systems; rather, a slow depletion is more likely, especially when dung is dried and used for fuel or sold to horticultural farmers in the vicinity. There is a small risk of nitrogen leaching, which takes place when the animals are housed in so called Kraals.

In developing countries with pastoralist populations, traditional herders support subsistence livelihoods by selling live animals at local markets. In some countries in the Horn of Africa and the Sahel, pastoralists also supply cattle, sheep, goats and camels to traders who export live animals to traditional trading partners, mostly in the Near East and the growing coastal urban centres in West Africa. However, increasingly stringent sanitary standards are threatening this trade. Pastoralism is under threat worldwide as mobility and access to traditional grazing areas become increasingly restricted through border controls and the expansion of land cultivation or, especially in parts of Africa, activities related to nature conservation. In addition, climate change seems to be making arid and semi-arid areas even drier, as a result of which extreme weather events, including drought and floods, are likely to become more common. Traditional coping mechanisms tend to fail in these situations and pastoralists are abandoning livestock production, voluntarily or involuntarily, in increasing numbers (Thornton et al., 2002).

\subsubsection{Snapshot 5: India pastoralist buffaloes}

India is a large country with a huge variety in climate, landscape and agricultural production systems. Indian pastoralists keep animals for a number of purposes: the production of milk, meat, fibre and labour. They keep different species of livestock. Because of the diversity of environmental conditions, there is also a wide variety of pastoral systems in India. What all systems have in common is their low intensity in terms of animals per area of land. A typical example of pastoralism can be found in India in the Shivalik foothills of Uttar Pradesh and Uttarakhand. The main religion is islam, which is linked to a lower aversion to consuming slaughter animals compared to the Hindu population.

Households spend the winter in the forests of the Shivalik foothills, where they live in temporarily erected huts. In the winter, the region provides enough feed for the 20 to 50 buffaloes owned by the households. Buffaloes are chosen in this example, because slaughtering buffaloes and exporting buffalo meat as beef is allowed. India is even one of the largest beef exporters in the world, based on buffalo production. Part of the feed comes from lopping off tree leaves, and this is presumed to be important for the milk's taste. In the summer, the vegetation and the creeks dry out, and households migrate to the summer camps higher in the Himalaya mountains. A few households band together to migrate. The whole household is involved in milk production. The surplus milk is sold to sedentary people in the area. Animals are also used as a kind of savings. This lifestyle is being threatened because the Indian government is creating national parks in the areas where they spend summers and winters, and limiting access to traditional grazing grounds, although pastoralism is also essential for the preservation of the landscape in the areas where it is practised. ${ }^{21}$

Typically, annual production of a herd of 100 buffalos is estimated at about 3,500 kg live weight of meat and $21,250 \mathrm{~kg}$ milk (our own calculations, based on inputs from FAO's GLEAM model). In addition to skin/hides and fibre (the wool of other animals) pastoralists harvest a number of other products from the areas they inhabit, e.g. honey. Agro-tourism is not developed in India, but does have potential. ${ }^{20}$

\footnotetext{
19 Stover is the straw of millet, sorghum and maize.
}

20 Personal communication with Pablo Manzano Baena 
The relative low output per animal in the pastoralist system corresponds with low external inputs: no chemical fertilizers, external feed inputs (or at a very low level), machinery or irrigation are used, and a few antibiotics are used either, mainly because of poor access to veterinary services. The labour is supplied by household members.

Nitrogen $(N)$ and phosphorus $(P)$ balances range between $-1 \mathrm{~kg}$ and $+1 \mathrm{~kg}$ per ha per year. There will be no surplus of nutrients going into the systems; rather, a slow depletion is more likely, especially when dung is dried and used for fuel or sold to horticultural farmers in the vicinity. There is a small risk of leaching, $9 \mathrm{~kg} \mathrm{~N}$ per ha and almost no P. The greenhouse gas emissions are estimated at $46 \mathrm{~kg} \mathrm{CO} 2 \mathrm{eq} /$ $\mathrm{kg}$ carcass weight (Opio et $\mathrm{al}_{.}, 2013$ ). The use of dung as fuel causes health problems for the pastoralists (Bihari et al., 2014, 2013; Joon, 2014; Mukherjee et al., 2014; Singh et al., 2014). Access to public services is poor, e.g. health care and education. When children from pastoral communities are sent to schools they often end up leaving the communities, as a result of which there is a lack of doctors and lawyers, for example.

In India the increase of the human population is threatening the pastoral systems. For instance, the increase of motorized travel along migration routes causes animal losses. Moreover, the availability of grassland is reduced by increased farming activities driven by population growth. This also has an impact on traditional wildlife and ecosystems. Already a shift has occurred from a nomadic to a relatively sedentary existence in a restricted area. Moreover, the creation of national parks limits access to traditional grazing grounds and decreases the area available for the pastoral herds.

\subsubsection{Snapshot 6: Brazil}

Brazil is one of the world's largest beef producers with an estimated 189 million head of beef cattle and production of over 9 million tonnes of meat (FAO, 2015a). It has the second-largest cattle population in the world (the first is India) and is one of the largest exporters of bovine meat in the world. Beef production occupies more than 140 million hectares of land in Brazil, almost twice that occupied by all other crops (Ferraz and de Felicio, 2010). Production efficiency per hectare has improved by $25 \%$ in the past ten years (Brazilian Beef, n.d.). The dominant production system for beef in Brazil is extensive pastoral production, with an estimated $82 \%$ of all animals raised under this system in 2008 and the remainder produced via feedlots (Ferraz and de Felicio, 2010).

Brazil is a large country with a huge variety in climate, landscape and agricultural production systems. Currently most of the beef production takes place in the Cerrado regions. A typical example of a beef cattle production system is located in the state of Mato Grosso, and has three separate components: cow-calf, stocker and feedlot. One ha of pasture is available per animal, rotational grazing is applied for the cow/calf and stocker operations. Roughage production is enhanced by the use of improved grasses, and the share of cultivated pasture (currently 65\%) is steadily increasing with a decreasing share of natural pasture. A farm has typically up to 5,000 animals. The labour required is supplied by hired personnel and the farm owner who also owns the farmland. The types of animals are Brazilian Bos indicus breed types (in particular Nellore) and crossbred Bos indicus x Bos taurus cattle. Crossbreeding of the Bos indicus breed, adapted to tropical circumstances, with European beef breeds (Bos taurus) enhances productivity and improves meat quality. Farms generally use artificial insemination. A beef cattle herd of 300 animals produces on average 48 animals annually for slaughter or a total live weight at slaughter of $28,000 \mathrm{~kg}$. The lactating animals are not milked, but only suckled by their calves. Potentially, by decreasing the age at first calving and by increasing growth, the annual production of this herd could be increased to $31,000 \mathrm{~kg}$ live weight at slaughter.

A typical beef cattle farm provides housing, education, health care and income for a number of households. The land area owned by the farm owner usually exceeds the area used for farming. Landless farmers and indigenous people use part of this unused land, and particularly when the beef production expands this can cause conflicts between the land owner and indigenous people.

Although the production of beef in Brazil is generally based on limited external inputs, the Brazilian system uses a relatively high level of inputs during the finishing phase in the feedlot. Pasture is the primary feed source for the cow/calf and stocker components. In the feedlot, feed rations are determined with minimal amounts of roughage and with by-products of the food industry, soy and grains. Fertilizer is 
used both on pasture and on crop land to produce feed used for the feedlot. Machinery is used for field work and feeding in the feedlot. Irrigation is not practiced. A system for tracking and tracing meat has been implemented. Antibiotics are used in the feedlots.

According to the World Organisation for Animal Health (see www. OIE.int) some zoonoses do occur in Brazil, but due to the size of the country and climatologic and geographic differences, the health status differs between states. Track and trace is used to monitor the use of antibiotics, particularly for some export markets. Foot-and-Mouth Disease (FMD) is still endemic in Brazil. Most states in Brazil vaccinate against FMD. Working conditions for personnel are considered safe, and employers provide them with health services.

\subsubsection{Snapshot 7: Tanzania dairy mixed feeding}

Dairy production in Tanzania is dominated by smallholder production, particularly within the highland areas of the country where over 190,000 small-scale dairy farms operate (Swai and Karimuribo, 2011). In 2011 total dairy production in Tanzania was estimated at approximately 1.7 million tonnes (FAO, 2015a).

The share of the smallholder farms in milk production is decreasing in Tanzania, while that of large-scale modern farms with grade cattle is increasing. The majority of the dairy cows on smallholder farms are crossbreeds of Friesian, Jersey and Ayrshire to the Tanzania Shorthorn Zebu with an average production of around 1,500 kg/year. A typical cattle herd of 5 dairy animals gives a total milk output of 7,500 kg. On average, one cow slaughtered annually delivers $320 \mathrm{~kg}$ of live weight.

The Tanzanian government aims to increase dairy production. Only 30\% of the national milk processing capacity is utilized. Particularly, poorer urban families have low consumption of dairy products. Human nutrition can improve if more dairy products are included in the diet.

Most of the dairy cows in Tanzania are kept by mixed smallholder farms in the highlands with 1-5 cows. The land in the highlands is under considerable pressure since there is also intensive crop production. The feeding of dairy cattle is based on crop residues, roadside grazing and occasionally on fodder crops. Conservation of feed (roughage) is not very common and technically not easy at the smallholder level. Occasionally, concentrates or feed supplements are purchased. Feed supply and feed quality are major constraints for milk production. These farmers in rural areas focus on the local markets and have limited direct sales to consumers, and mainly rely on middlemen.

On the other hand, there are also smallholder dairy farms in urban and semi-urban areas. These farms have higher input levels and most of their milk is sold on informal local markets, which is generally more profitable than the formal market. There is lower production in the dry season compared to the rainy season. In the wet season more milk is marketed on the informal market. Overall, around $70 \%$ of the milk produced on smallholder farms is sold (mainly to informal markets), the rest is consumed at home. The technical inputs to the Tanzanian mixed dairy system are low. There is limited use of artificial insemination. Fertilizer and irrigation are not used because the animals are fed with roughage from crop residues and sometimes roadside grazing is applied. No information is available regarding the use of antibiotics.

Nitrogen $(\mathrm{N})$ and phosphorus $(\mathrm{P})$ balances range between $-1 \mathrm{~kg}$ and $+1 \mathrm{~kg}$ per hectare. $\mathrm{N}$ leaching is estimated at $8 \mathrm{~kg}$ per ha and $\mathrm{P}$ leaching is negligible. There is an increased risk of leaching when zero grazing is applied and animals are confined during the whole year, as most of the urine is lost. Greenhouse gas emissions are equal to $3.3 \mathrm{~kg} \mathrm{CO}$-eq/kg milk (Opio et al., 2013).

According to OIE (World Organisation for Animal health), there are several zoonoses. Presumably, antibiotics are used to cure cows and residues in milk, which could contribute to antibiotic resistance, but it is not sure to what extent this happens. Poor feed conservation could cause problems with aflatoxin, but again it is not clear if this is the case. 


\subsubsection{Snapshot 8: India dairy mixed feeding}

Milk production is the primary focus of cattle industry in India and is dominated by traditional small-scale production on farms of two to five cattle (IndexMundi, 2015). The Indian government started a project in 2012 with the aim of doubling dairy production within 15 years while maintaining the small farm size. Key elements are improvement of rations, roughage production and roughage conservation, breeding (with optimum use of indigenous breeds) and the use of AI by improved logistics. In most areas cooperatives take care of milk collection and shipping to a milk processing plant (National Dairy Development Board, 2012).

$90 \%-95 \%$ of dairy production in India comes from small mixed family farms, where income from dairy products is not the only source of income. Within India only in the state of Punjab larger farms with 50 to 500 animals are more common. More than $50 \%$ of the milk comes from buffaloes $(200,000,000$ of the $300,000,000$ dairy animals are buffalo, the rest are cattle), but the milk from cattle and buffalos is not collected separately. Hindus in principle do not eat meat and the majority of the people in India are Hindu. This explains the huge demand for protein from dairy production for human consumption.

A cattle herd of 5 dairy animals and their offspring produces each year a maximum of only 1 animal that can be sold or slaughtered for home consumption (350 kg of live weight) and a milk output of 5,000 kg, part of which is for home consumption, while the rest is sold. Hindus make up more than $80 \%$ of the population. Cattle are considered sacred in Hindu religion and as a consequence there is a strong reluctance to slaughter cattle and other farmed animals in many regions in the country.

The intensity of the dairy system is medium high. There are national breeding programmes, and AI infrastructure exists for cattle and buffalo. Artificial insemination is used throughout the country. Fertilizer use is strongly supported by the Indian government and is cheap, but it is mostly applied for crop farming. Manure is mainly used as fuel. The feed consists of crop by-products produced in the vicinity of the farm. By-products from the human food industry are rarely used and there is little organized concentrate production. There is extensive use of machinery. Irrigation is used for crop production. Antibiotics are easily available and cheap, but milk is not regularly tested for antibiotics residues. From a personal communication, we understand that both mastitis and the use of antibiotics to cure mastitis are problems.

Due to the frequent use of synthetic fertilizers and the purchase of agro-industrial by-products, $\mathrm{N}$ and $\mathrm{P}$ surpluses are relatively high: $148 \mathrm{~kg}$ and $23 \mathrm{~kg}$ per hectare, respectively. $\mathrm{N}$ leaching is estimated at 63 $\mathrm{kg}$ per ha and there is almost no $\mathrm{P}$ leaching. Greenhouse gases are equal to $4.7 \mathrm{~kg} \mathrm{CO}$-eq/kg milk (Opio et al., 2013).

According to OIE there are several zoonoses, and FMD is endemic. Because food security (protein supply) is a major concern of the government at the moment, surveillance does not have priority. Other public health aspects are residues of antibiotics in milk and aflatoxin from poor feed conservation. On the other hand, dairy products are the major source of animal protein in human nutrition in India.

\subsubsection{Snapshot 9: The Netherlands dairy specialized}

Dutch dairy production is based upon a large number of dairy farmers (approximately 17,000 ) organized into large cooperatives that are responsible for processing and distribution (Philippot et al., 2011). The consolidation of cooperatives has led to one cooperative controlling $75 \%$ of total production (Baltussen et al., 2014). Dairy production in the Netherlands is highly productive relative to other producing nations due to investments in research and development, and in mechanization and automation (ibid). The Netherlands has a long-standing tradition of dairy farming, which traditionally occurred on soils where crop production was impossible or difficult. The country is more than self-supplying in terms of dairy products, and a large part of the national production is exported in the form of cheese. A typical Dutch dairy farm is a specialized family farm with around 85 dairy cows and young stock for replacements. The Holstein Friesian (specialized dairy breed) is the dominant breed in the Dutch dairy population. 
A typical dairy farm has around 50 ha of land available for grazing and crop production. Around $70 \%$ of the dairy herds have access to pastures during the grazing season for at least part of the day, otherwise the animals are indoors. Cubicle barns with slatted concrete flooring are the main housing type. More than $18 \%$ of the bigger farms use automatic milking systems. Roughage mainly consists of grass and silage maize. Besides roughage, cattle are fed a considerable amount of concentrates, part of the ingredients of which are imported via Rotterdam harbour. Particularly in areas with sandy soils, land is irrigated in dry periods during the growing season. Most of the milk is collected by dairy processors. Since April 2015 national milk production restrictions by the EU quota system have been dropped. The sector expects a growth of about $20 \%$ in milk production till 2020.

The Dutch dairy system is characterized by high input and high output per cow and per ha. The output of an average dairy farm consists of $700,000 \mathrm{~kg}$ of milk and $15,800 \mathrm{~kg}$ of meat from culled cows and heifers. Many dairy farms use their own manure as fertilizer and specialize in dairy farming. Some farms have a high animal density per ha and have to sell the manure to crop producers. Some of the farms are more multifunctional. They also engage in other activities, such as agro-tourism, education and health care, and they produce and sell cheese.

High inputs include the standard use of artificial insemination, the frequent use of fertilizer, the use of concentrates, a high input of machinery for feed conservation, milking and grassland management. Irrigation takes places in sandy areas during dry periods. The use of ground and surface water for irrigation is restricted by authorities. Most of the labour is supplied by the owner, contractors, family members and sometimes hired personnel. The use of antibiotics is high but programmes are in place to reduce the use of antibiotics by $70 \%$.

Due to strict regulations, $\mathrm{N}$ and $\mathrm{P}$ surpluses have decreased in the last decades. Currently, the $\mathrm{N}$ surplus is $165 \mathrm{~kg}$ per hectare, whereas there is a tendency towards a P shortage of $-8 \mathrm{~kg}$ per hectare. Calculated $\mathrm{N}$ leaching is $118 \mathrm{~kg}$ per ha and there is no $\mathrm{P}$ leaching. Greenhouse gases is equal to $1.4 \mathrm{~kg} \mathrm{CO}$-eq/ $\mathrm{kg}$ milk (Opio et al., 2013).

There are monitoring programmes in place for most zoonoses. Moreover, programmes to improve the health status of dairy cows and eradicate specific infectious diseases are in place. A programme to stamp out contagious diseases has been set up.

\subsubsection{Snapshot 10: Indonesia dairy mixed feeding}

In Indonesia there was no tradition of dairy farming, apart from some dairying introduced by the Dutch colonists. Moreover, dairy products traditionally are not part of the Indonesian diet. Since the 1970 s a dairy sector was built up on Java through government initiatives starting with Holstein cattle imported from Australia. These animals were given to smallholder farmers, mainly on the island of Java in areas above 1,000 meters of altitude.

The number of smallholder farmers (particularly those that are landless) is expected to decrease, and the number of medium and large-scale farms will increase. Those large farms are expected to be partly landless or at least not self-sufficient for roughage. The demand for fresh locally produced milk is expected to increase in Indonesia because of the income increase and the fact that fresh milk is associated with health.

A typical smallholder farm holds about 2-5 cows, and many of them are landless and obtain roughage from roadside grazing or crop residues. Concentrates are available and farmers can obtain credit (repayment through milk sales) to buy them. Roughage supply and quality is poor and often resulting in a too high amount of concentrates in the rations. It is common for farmer families to have additional sources of income besides milk production. Larger farms exist, and are usually owned by agricultural firms and/or milk processing companies. Cooperatives play an important role in the sector as intermediates between the primary farms and the milk processors. This system is similar to the situation in India. In addition to collection many cooperatives provide services such as artificial insemination, veterinary support, feed, financing and information services. The level of self-support in the country is still low, and more than $50 \%$ of the dairy products are (partly) made from imported milk powder. The quality of locally produced 
milk can be low, and therefore is mainly used for products with a long shelf life. Most of the global players in the dairy industry are represented in the country. Milk production is still concentrated on the island of Java, although there are some initiatives to expand dairy farming to the Sumatra and Sulawesi regions.

The estimated output of a farm with 5 cows is $350 \mathrm{~kg}$ of meat (live weight) and 7,000 kg of milk. The solid manure fraction is sold to crop farmers, while the urine leaks out of the system. Most dairy cattle are kept under zero grazing and fed by grass cut by the farmers along roadsides and by roughage from crop residues. At the farm the only machinery used are trolley milkers for milk harvesting as well as small choppers for roughage preparation. Milk collection centres use milk cooler tanks for storage and transport. Antibiotics are probably used. It is unknown if the milk is tested for residues. The work on the farms is done by both men and women.

Due to the use of off-farm feed, $\mathrm{N}$ and $\mathrm{P}$ balances show relatively high surpluses: $65 \mathrm{~kg}$ and $6 \mathrm{~kg}$ per hectare, respectively. $\mathrm{N}$ leaching is $20 \mathrm{~kg}$ per ha and there is almost no $\mathrm{P}$ leaching. Greenhouse gases are equal to $3.5 \mathrm{~kg} \mathrm{CO}$-eq/kg milk (Opio et al., 2013).

There are several zoonoses, including leptospirosis (see www.OIE.int), but information about prevention and control programmes is missing. Health risks are reduced because most of the milk is pasteurized by the milk processors.

\subsection{Assessment and valuation of the snapshots}

In this section, the results of an overall integrated assessment of livestock production systems is presented per group of snapshots (poultry, beef and dairy), and some snapshots are compared where such a comparison is viable and relevant. The indicators used for this assessment can be found per snapshot in annex A.

\subsubsection{Poultry systems}

Three different poultry systems in Tanzania, Indonesia and the Netherlands (snapshots $\underline{1}, \underline{2}$ and $\underline{3}$ ) were assessed.

\section{Productivity and efficiency}

The poultry snapshots are very different in terms of productivity (output in kg protein) and efficiency (inputs per kg protein). Small-scale poultry systems produce less kilograms of protein per unit of input and are more labour intensive compared to medium and large-scale production systems. They also differ in their contribution to food security. Small-scale backyard poultry play an important role at the local level. They provide an essential part of the human diet and also represent an important income source for women. Medium-scale and industrial systems deliver to urban markets and are increasingly important for global food security.

In general input efficiency increases when farm scales increase, resulting in professionalization of the system (breeds, feed, veterinarian, climate control and disease control) and high investments. On the other hand, small-scale, backyard systems depend much less on external inputs (such as feed and antibiotics) and investments compared to large-scale industrial systems. Small-scale systems play an important role in food security and livelihood for many poor small-scale farmers and in some countries these systems are important for females. The productivity level of the backyard systems is so low that they are not able to feed large urban populations.

\section{Natural capital}

Chicken offers a relatively high protein production per unit of natural capital, compared to dairy and beef systems. The land-use change component in natural capital costs, associated with medium-scale and in particular large-scale poultry production, is relatively high and not significant for backyard poultry. Increasing the scale of poultry production from snapshot 1 to 3 generally results in lower negative external impacts per kilogram of protein, but high concentrations of animals can have negative local 
impacts that have to be mitigated. The latter are mainly linked to the accumulation of nutrients in manure. Manure is also a positive output of the poultry system as long as the density in the region is not too high. In countries like the Netherlands, manure (even dried manure) has a negative value and even becomes a cost for farmers.

Water pollution is considered to be negligible in the case of scavenging chickens and when manure management is well controlled. On the other hand, the negative impact of feed production on water pollution was not taken into account for poultry systems. The dependency of blue water use is also significant (but limited) for medium and large-scale poultry systems due to irrigation for feed production.

\section{Animal and human health}

Poultry production has a relatively high risk of zoonoses. This is the case for small-scale and large-scale production, but the mechanisms and risks are of a different nature. In small-scale systems people are more continuously in direct contact with animals. Industrial systems are more market oriented and are therefore likely to be better controlled. OIE figures (www.oie.int) show that many countries report a long list of diseases that are clinical in the country and often notifiable. This is also the case for poultry (related) diseases and zoonoses.

Preventive use of antimicrobials is quite common in medium and large-scale poultry production, posing the risk of increasing resistance against antibiotics. Zoonoses should be controlled without excessive and preventive use of antibiotics. Antibiotics are often relatively cheap and used in a preventive way to hide the defects of the production system, but there are also best practices where high productivity is possible without the preventive use of antibiotics. In that sense, the interaction between the type of animal/breed and the level of management in the poultry system is important. Local breeds are generally more robust but less productive. Specialized breeds are important because of the high productivity but results will only be positive when good management is practised.

\section{Biodiversity and ecosystems}

Poultry systems generally do not have a substantial direct impact on biodiversity and ecosystems. They are largely disconnected. Indirect impacts, however - through the production of feed - are substantial and depend on the location and intensity of crop production. Feed requirements, which are determined by looking at feed conversion rates (FCR - the ratio between feed consumed and protein productivity), are key factors for calculating land-use impacts.

Backyard poultry are more integrated in local agro-ecosystems compared to medium/large scale. At the same time, backyard systems have no or a very limited negative impact on the ecosystem and biodiversity. Medium and large-scale farms show no direct effect on ecosystems and biodiversity, but the indirect effects through feed should not be neglected. The relatively high land use in medium-scale systems compared to the industrialized systems is due to the lower yield of the crops for feed production.

\section{Cultural heritage}

Small-scale backyard systems, including the type of breeds used, often have additional value for agro-tourism and cultural heritage. This is not relevant for the more industrialized poultry systems.

\subsubsection{Beef systems}

Three different beef systems in Tanzania, India, Brazil (snapshots $\underline{4}, \underline{5}$ and $\underline{6}$ ) were assessed.

\section{Productivity and efficiency}

The beef snapshots are very different in terms of productivity (output in kilograms of protein) and efficiency (inputs per kilogram of protein). Pastoral systems produce less kilograms of protein per unit of land or input and are more labour intensive compared to medium and large-scale beef production systems. In general input efficiency increases when farm scale increases and more meat is being produced per hectare of land. This is only possible with a professionalization of the total livestock system (breeds, feed, veterinarian and disease control) and grassland management. The Brazilian system relies strongly on the availability of land, and relatively low financial capital and human inputs. The situation is the opposite in the finishing phase of beef production in feedlots in Brazil. Animals are confined in a 
limited area and this phase relies on high external inputs (feed, antimicrobials and labour). However, in total, extensive beef systems depend much less on external inputs and financial investments compared to more industrial systems.

Both pastoral systems and extensive, large-scale beef systems make an important contribution to food security, at the local level and beyond, and to the livelihoods of many poor small-scale farmers all over the world. Market orientation and the commercial trade of beef production increases along with the scale and production level of the system. The productivity level of the pastoral systems is so low that these systems are not able to feed large urban populations. The Brazilian system is characterized by a low input of labour per $\mathrm{kg}$ of protein.

\section{Natural capital costs}

Beef cattle offers a relatively low protein production per unit of natural capital, compared to mixed dairy and poultry systems. The increase in scale of cattle production per farm results in lower negative impacts per kilogram of protein. Concentrations of animals in feedlots can result in local negative externalities, for example the leaching of minerals to the groundwater. These externalities should be mitigated by better manure management, for example. The latter are mainly linked to nutrient accumulation in manure (see the feedlot example in Brazil) or disease management.

Water pollution costs - associated with nitrogen $(\mathrm{N})$ and phosphate $(\mathrm{P})$ nutrients from excretion at the farm level are relatively high for the Indian pastoralist system compared to the Tanzanian pastoralist or Brazilian beef extensive systems. The costs of blue water use are negligible for the pastoralist systems and extensive beef systems in Tanzania, India and Brazil, because no irrigated blue water is used for production of feed.

Pastoral systems show high land occupancy per kilogram of protein produced. Extensive beef production systems in Brazil perform better because they use more specialized and efficient beef breeds compared to pastoral systems. Although pastoral systems have much higher land occupancy than extensive beef systems, pastoral systems make use of natural pastures and ecosystems and contribute to the maintenance of those agro-ecosystems.

\section{Animal and human health}

Beef production has a relatively low human health risk. This is the case for both pastoralist and extensive, large-scale beef production. OIE figures (www.oie.int) show that many countries report a long list of diseases that are clinical in the country and often notifiable. This is also the case for beef cattle (related) diseases and zoonoses. However, health risks with beef regarding salmonella and campylobacter are low compared to other types of meat. Preventive use of antimicrobials is absent in pastoral systems but more common in extensive beef production system with feedlots. The more industrialized systems are market oriented but zoonoses need to be controlled as well as diseases, without the excessive use of antibiotics.

\section{Biodiversity and ecosystems}

Pastoral and extensive, large-scale beef production systems have a direct impact on biodiversity and ecosystems through grazing. Substantial differences exist between the beef systems regarding land use, habitat encroachment, soil erosion and water pollution. But because of differences in soil fertility and climate, the comparability of systems is low. In general pastoralist systems go hand in hand with conserving the ecosystem. If these systems are intensified the biodiversity will decline quickly. The main risk of pastoralist beef systems is overgrazing. Overgrazing can cause the entire ecosystem to collapse by erosion. The introduction of feedlots, however, increases the use of external feed sources. This can be by-products of sugar cane or citrus production but also soy and corn. For the latter products, the area of arable land will increase at the cost of grassland with lower carbon fixation, higher erosion risk, higher susceptibility to drought and higher leaching (at least of the urine but probably also of the faeces). Herds of Tanzanian Maasai cattle graze on the Maasai Steppe, a region with a high biodiversity value and a high concentration of wildlife in the country. Traditionally, both cattle and wildlife use the Maasai Steppe for feeding. Pastoralist systems have a lower productivity per area of land, but a relatively high biodiversity and ecosystem value. Transformation of pastoral land to agricultural land is taking place as a strategy to improve the land's productivity, but land degradation and declining soil fertility are important 
trade-offs. A natural capital monetary valuation case study for the Maasai Steppe shows that conversion of steppe into farmland will result in overall natural capital loss. A recent publication in Nature also shows the negative impact of human activities, and the conversion and degradation of habitats, in particular, are causing a decline in biodiversity (Newbold et al., 2015). See chapter 5 for more details about the monetary valuation of natural capital in the Maasai Steppe.

\section{Cultural heritage}

The pastoral systems have a high bio-cultural value, including traditional lifestyles and maintaining indigenous livestock breeds. The pastoralist system is attractive for tourists. The Brazilian beef system is more specialized and this large-scale, extensive system has less additional value for tourism and cultural heritage.

\subsubsection{Dairy systems}

Four different dairy systems in Tanzania, India, the Netherlands and Indonesia (snapshots 7, 8, 9 and 10) were assessed.

\section{Productivity and efficiency}

Different intensities of the dairy production systems are the result of differing inputs per kilogram of protein. Productivity on a specialized dairy farm in the Netherlands is very different from the mixed dairy systems in Tanzania, Indonesia and India. Productivities of mixed dairy systems in Tanzania, Indonesia and India are in a similar range, which is much lower than a dairy system in the Netherlands. All dairy systems produce both milk and beef. The mixed dairy systems in India, Tanzania and Indonesia have an average of circa 5 cows producing $70 \mathrm{~kg}$ to $100 \mathrm{~kg}$ of live weight and 600-1000 kg of milk annually per animal. In contrast, the representative Dutch system assessed produces a far higher output per animal of more than $4,300 \mathrm{~kg}$ of milk and about $100 \mathrm{~kg}$ of live weight. ${ }^{21}$ Aside from live animals and milk, other outputs are not significant. Manure in the Netherlands is sometimes sold as fertilizer. Manure has to be transported because otherwise minerals will leach to the groundwater. This transport becomes a financial cost instead of a benefit if animal densities in a region and at farm level exceed threshold levels.

In general input efficiency increases as the farm scale in dairy systems increases and requires professionalization of the system (breeds, feed, veterinarian, climate control, disease control and grassland management) and high financial investments. In the Dutch dairy system, additional concentrated feed is used to increase milk production per cow. The small mixed dairy systems in Tanzania, India and Indonesia are comparable with each other in the sense that milk cows are kept inside and fed with roughage, grass on roadsides and in particular crop residues. The inputs are low except for labour.

\section{Natural capital costs}

Intensive production systems (productivity in $\mathrm{kg}$ of protein per hectare of land) are usually associated with the increased leaching of minerals. However, although the Dutch mixed dairy system has the highest amount of nutrients leached per hectare of all snapshots, the water pollution costs per kilogram of protein produced are low due to its high productivity. Moreover, nitrogen leaching can be partially mitigated by permanently confining animals. The surplus of $P$ at farm level is low for all systems and the surplus of $\mathrm{kg}$ of $\mathrm{P}$ per hectare is about zero. The Indian and Tanzanian mixed dairy systems also have lower water pollution compared to pastoral systems.

Both the type of feed used and the milk production per cow influences the land use. Dairy systems are generally more intensive compared to beef systems. In particular the Indonesian and Dutch dairy systems have a very low land use per $\mathrm{kg}$ of protein compared to the other two mixed dairy systems in Tanzania and India.

\footnotetext{
21 Sold calves are in the meat part.
} 


\section{Animal and human health}

Dairy systems can have negative impacts on human health, food safety and antibiotic resistance. For countries with many smallholders, the health control, monitoring and organization is relatively difficult. OIE figures (www.oie.int) show that many countries report a long list of diseases that are clinical in the country and often notifiable. This is also the case for dairy system (related) diseases and zoonoses. Use of antimicrobials is limited in dairy production systems compared to other (industrial) livestock production, but the use of antimicrobials often goes undocumented. Antibiotics are relatively cheap and easily available.

\section{Biodiversity and ecosystems}

The studied mixed dairy systems in Tanzania, Indonesia India and the Netherlands have a relatively limited direct impact on biodiversity and ecosystems. The cows in the mixed dairy systems are kept inside, and exceptionally go outside for some grazing. Indirect impacts, however - through the production of feed - are substantial and depend on the location and intensity of crop production.

\section{Cultural heritage}

Agro-tourism is not clearly linked to mixed dairy production systems. However, cattle is considered a bio-cultural heritage, in particular also in India, where cattle are considered sacred in Hindu religion. As a consequence, there is a strong reluctance to slaughter cattle (but also other farmed animals) in many regions in the country. This also leads to a very high number of unproductive cattle in the country, making efficiency comparisons with dairy production systems in other countries quite difficult.

\subsection{Bottom-up quantitative assessment and valuation at snapshot level}

This section presents the results of a quantitative assessment of selected impacts. The analysis complements the results of the top-down quantitative assessment considering externalities (and dependency on blue water) of specific livestock systems rather than looking at the livestock industry at the macro-level. 22

The analysis is based on a quantitative environmental and economic supply chain model consisting of the farm and feed imports for each snapshot. This model is based on local data where possible. As the data requirements for a bottom-up valuation are substantial, we needed to select which impacts ${ }^{23}$ and dependencies to measure. Based on the materiality assessment and data availability, we chose the following scope:

- The impact on global warming of GHG emissions that arise via animal husbandry production systems;

- Water pollution of the production systems, with a focus on eutrophication for all snapshots;

- Land occupancy per unit of animal product for all snapshots and related biodiversity loss; and

- The dependency of systems upon blue water for those snapshots where irrigation is used for feed production.

All quantified impacts and dependencies are valued monetarily, except for land use as that impacts all ecosystem services involved on land and thus requires extensive data and modelling of the local environment and economy (see the next chapter for a case study of this analysis).

22 A detailed comparison of the results of the two quantitative assessment can be found in annex B: Comparison bottom-up and top-down methodologies and results

23 Productivity, use of farm inputs and on-farm impacts are modelled specifically to the livestock system, while for impacts in the supply chain of feed production country-level data is used, see Table 2.9 
To value GHG emissions, a social cost of carbon of US\$128 is used (the 95th percentile estimate under a $3 \%$ discount rate) (USIAWG, 2013). In order to estimate the value of blue water dependency, a residual rent method approach is used based on the increase in productivity from blue water and associated economic profit in each snapshot ${ }^{24}$ using local data. Water pollution is valued based on global monetary coefficients. Based on Weidema (2009) values of 0.42 euro (2003) per kg N-eq and 3.06 euro (2003) per $\mathrm{kg}$ P-eq were used. These values have been transfered to US dollars and corrected for inflation. For a detailed discussion of the these valuations see additional explanations provided in section 2.4 .2 and full details in True Price (2016), section II.2 for GHG, II.3 for water dependency, II.4 for water pollution and II. 5 for land occupation.

The results of the valuation of these externalities are further compared with retail prices, in order to put them in the context of the market for animal products.

The following sections illustrate the results of the bottom-up valuation for GHG, water pollution, land occupation and related biodiversity impact and dependency on blue water.

\subsubsection{Greenhouse gases}

The analysis confirms that poultry is the animal husbandry system with the lowest greenhouse gas emission per kg of animal protein. Among cattle systems, the Dutch dairy specialized system, interestingly, also appears to be extremely carbon efficient, almost reaching emissions comparable to poultry production. The three extensive cattle systems have the highest greenhouse gas impact per unit of output (figure 4.1 and table 4.1).

The analysis also shows that greenhouse gases released as part of animal husbandry processes are primarily associated with 1 ) enteric fermentation in the beef and dairy systems with ruminants, 2) organic and synthetic fertilizer and, to a lesser extent, 3) fossil fuels related to transport.

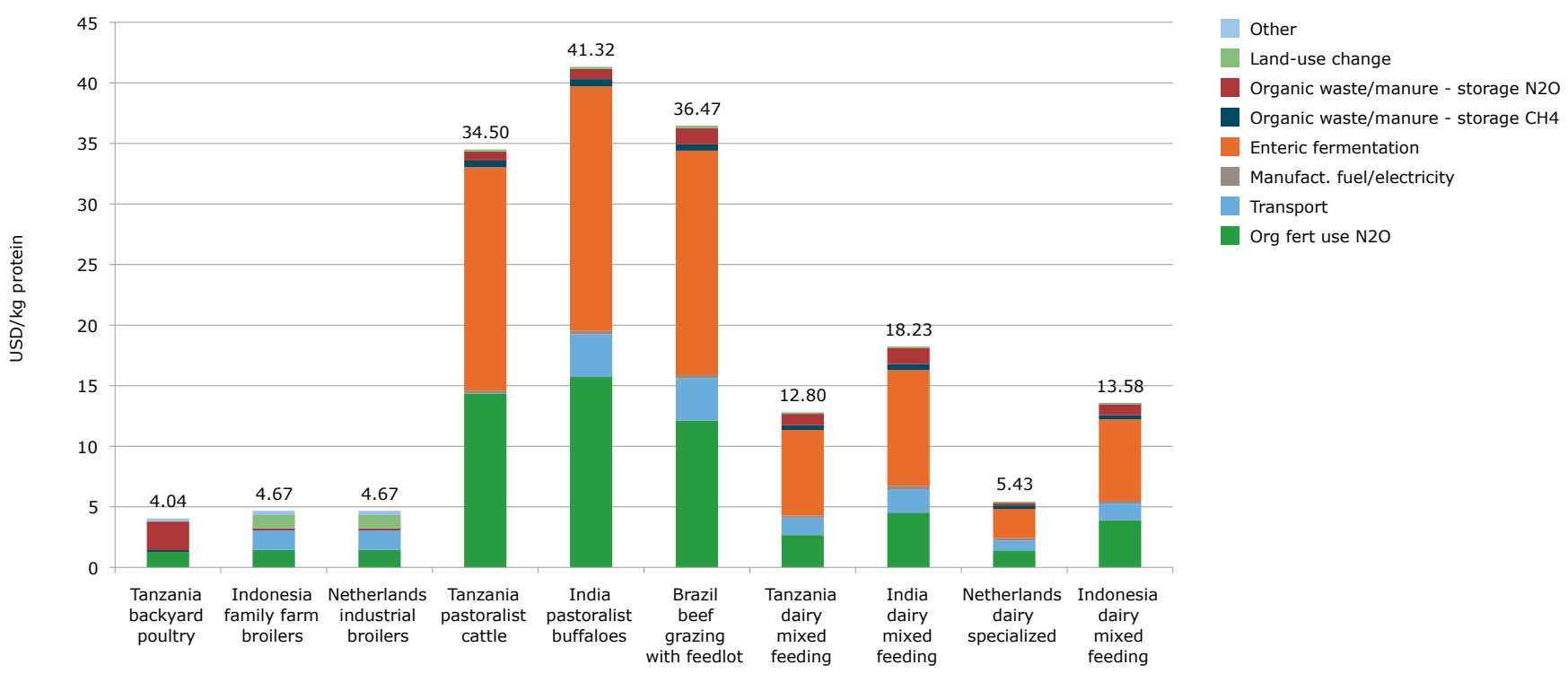

Figure 4.1 GHG Externalities for animal food products in the selected snapshots (USD/kg protein)

24 In this approach irrigated crop profits are compared with non-irrigated crop profits. The difference between these is divided by total water use to end up with an estimate of the added value of water to each specific crop 


\section{Table 4.1 Breakdown of GHG externalities for animal food products in the selected snapshots (USD/kg protein)}

\begin{tabular}{|c|c|c|c|c|c|c|c|c|c|c|}
\hline Unit: USD/kg protein & 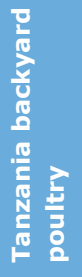 & 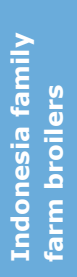 & 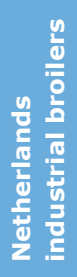 & 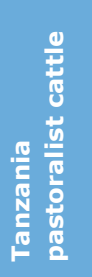 & 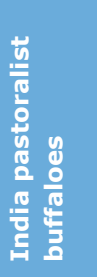 & 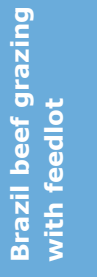 & 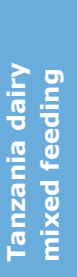 & 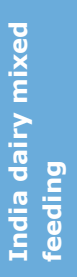 & 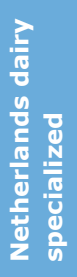 & 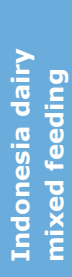 \\
\hline $\begin{array}{l}\text { Organic fertilizer } \\
\text { use N2O }\end{array}$ & 1.29 & 1.44 & 1.44 & 14.35 & 15.72 & 12.13 & 2.67 & 4.52 & 1.40 & 3.90 \\
\hline Transport & 0.00 & 1.62 & 1.62 & 0.00 & 3.54 & 3.50 & 1.43 & 1.93 & 0.82 & 1.36 \\
\hline $\begin{array}{l}\text { Manufact. fuel } \\
\text { /electricity }\end{array}$ & 0.00 & 0.00 & 0.00 & 0.25 & 0.27 & 0.24 & 0.18 & 0.29 & 0.22 & 0.24 \\
\hline Enteric fermentation & 0.00 & 0.00 & 0.00 & 18.43 & 20.18 & 18.53 & 7.07 & 9.54 & 2.40 & 6.71 \\
\hline $\begin{array}{l}\text { Organic waste } \\
\text { /manure - storage } \mathrm{CH}_{4}\end{array}$ & 0.13 & 0.00 & 0.00 & 0.55 & 0.60 & 0.52 & 0.40 & 0.52 & 0.29 & 0.35 \\
\hline $\begin{array}{l}\text { Organic waste/manure - } \\
\text { storage N2O }\end{array}$ & 2.36 & 0.18 & 0.18 & 0.76 & 0.83 & 1.32 & 0.99 & 1.36 & 0.23 & 0.99 \\
\hline Land-use change & 0.00 & 1.08 & 1.08 & 0.17 & 0.18 & 0.22 & 0.07 & 0.07 & 0.08 & 0.03 \\
\hline Other & 0.26 & 0.36 & 0.36 & 0.00 & 0.00 & 0.00 & 0.00 & 0.00 & 0.00 & 0.00 \\
\hline Total & 4.0 & 4.7 & 4.7 & 34.5 & 41.3 & 36.5 & 12.8 & 18.2 & 5.4 & 13.6 \\
\hline
\end{tabular}

Assessments of the different Brazilian systems indicate that the intensification measures examined (improved pasture management and fattening in feedlots) reduce GHG costs by up to $20 \%$ (figure 4.2 ). The improvement in carbon intensity can be explained by the expected efficiency gains of introducing improved pasture management techniques and a fattening period ('finishing') in feedlots.

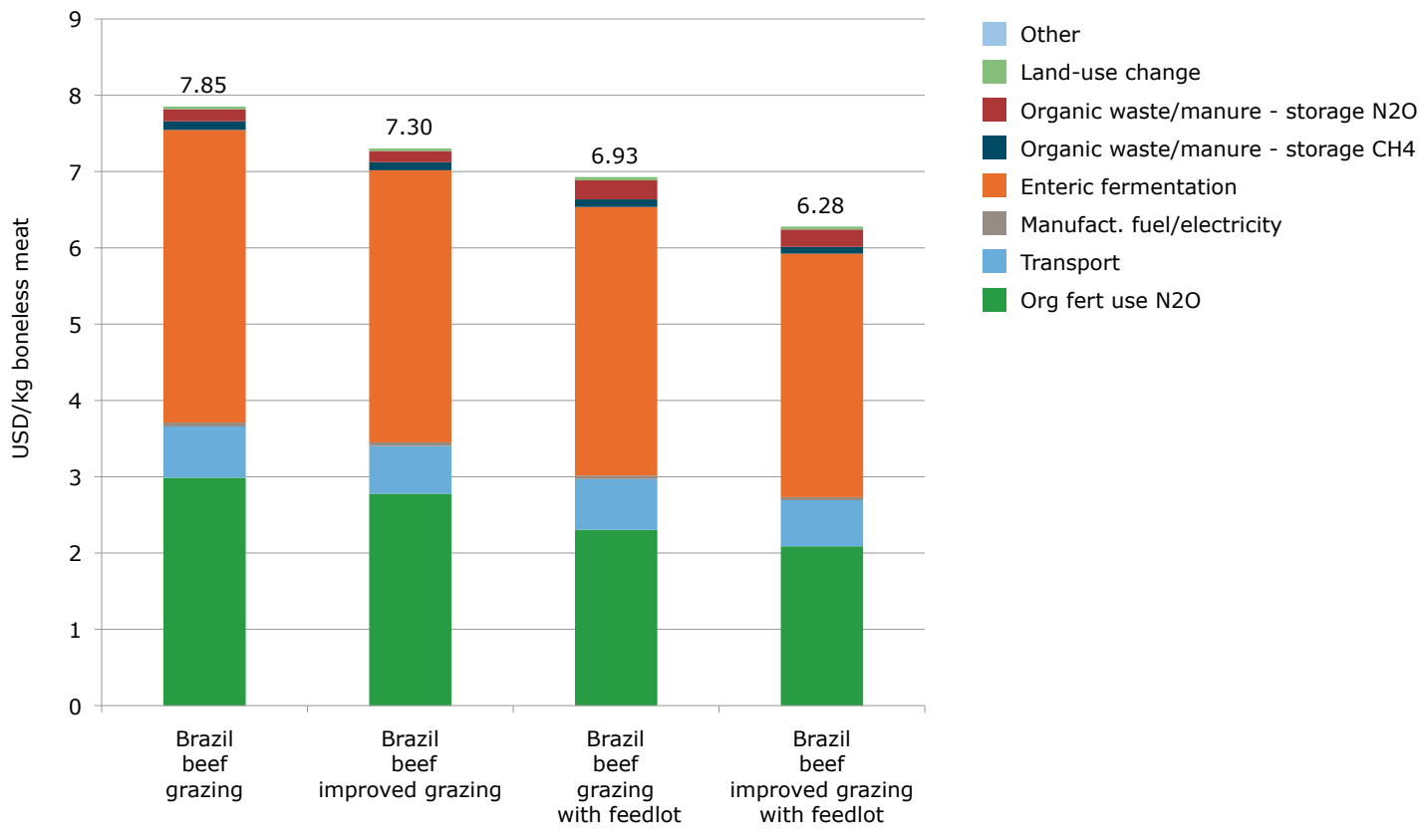

Figure 4.2 GHG Externalities for Beef Production Systems in Brazil (USD/kg boneless meat) 

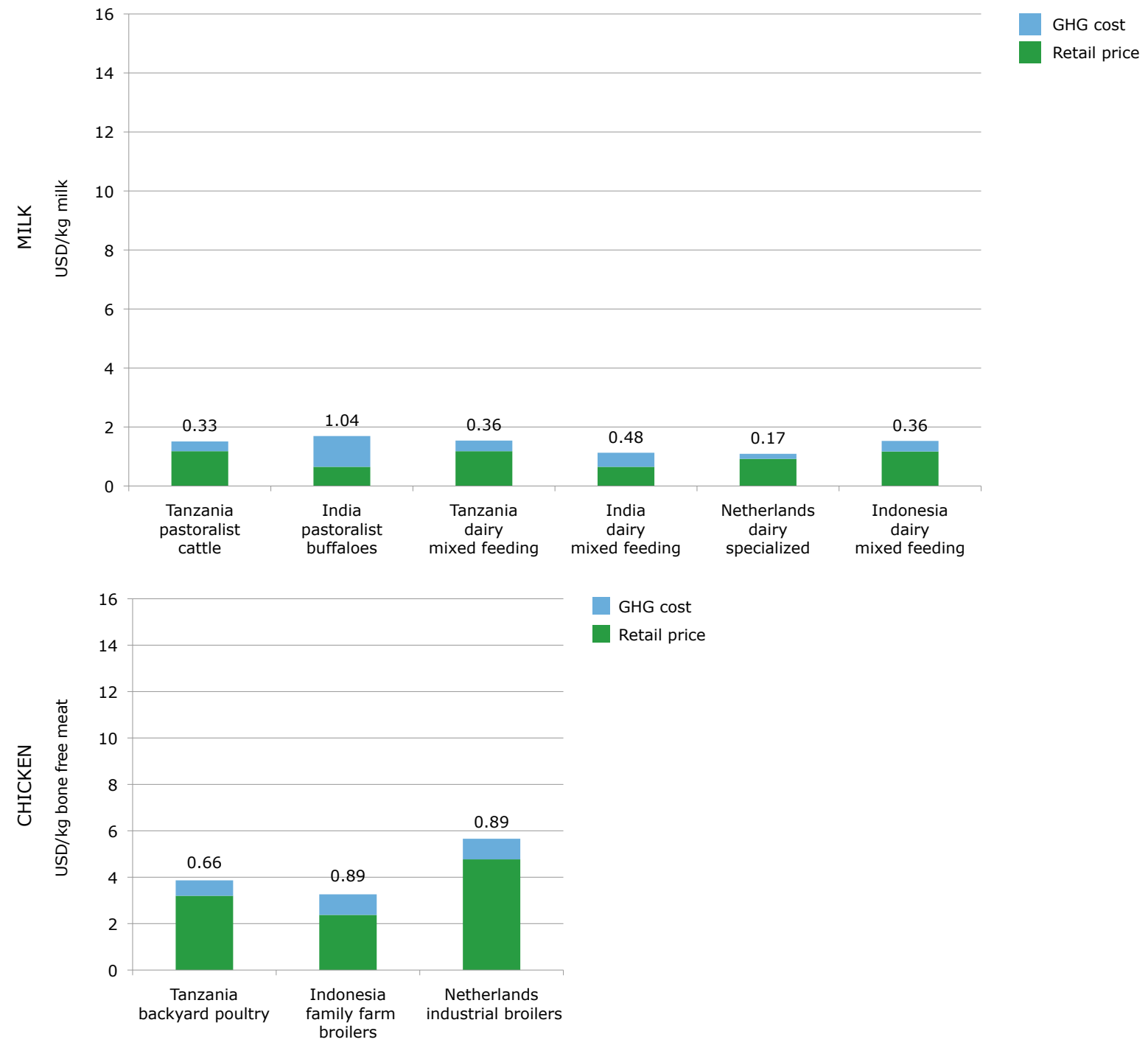

GHG cost

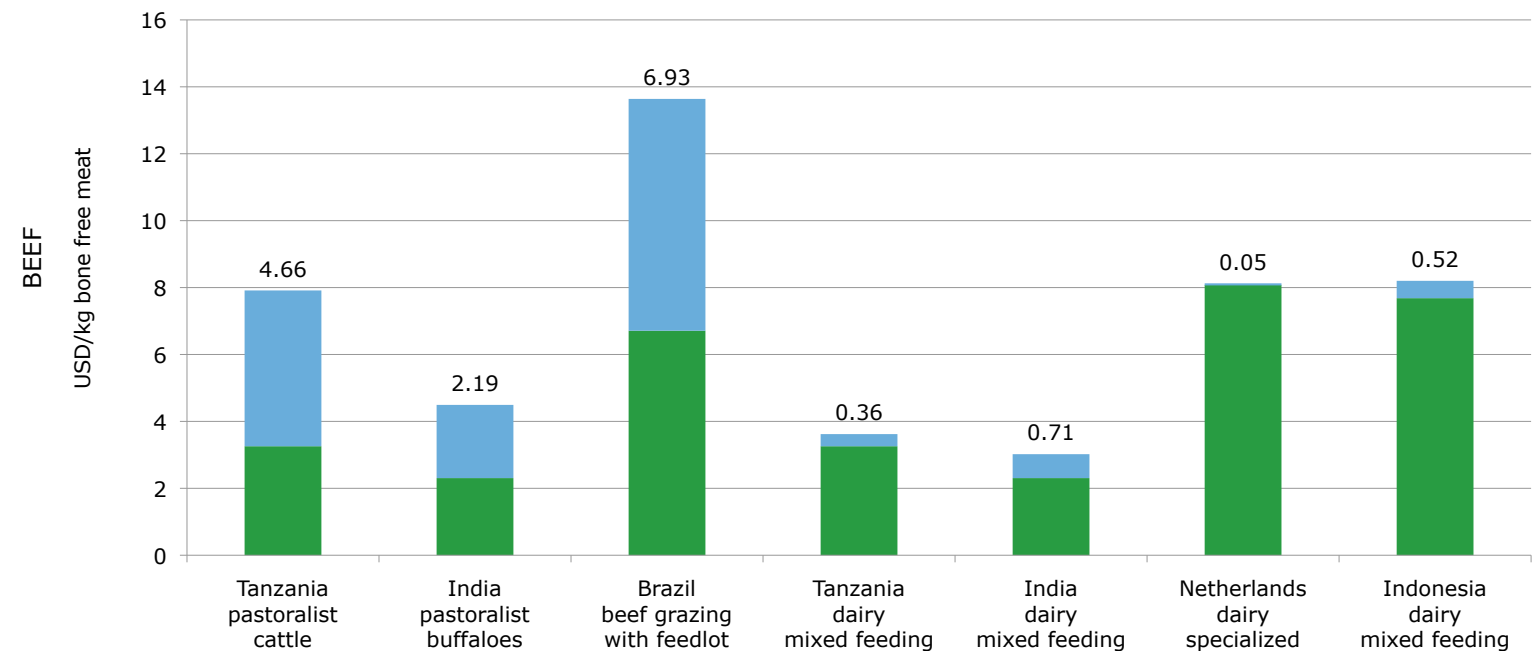

Figure 4.3 GHG externalities to retail price comparison for milk, poultry and beef correspondingly (USD/kg boneless meat). Note: the value on the top of the bar indicates the costs of GHG per unit of end product. 
Figure 4.3 shows how the external costs of GHG emissions relate to retail prices of meat and milk. This comparison makes it possible to understand the external costs and the costs borne by society as a whole as a result of the consumption of animal products in relation to the value of the products themselves. Furthermore, it can indicate to what extent internalizing these external costs within market prices, for example with environmental taxes or regulations, could affect the price of these livestock products. GHG externalities are a significant fraction of the price across all snapshots. They constitute $26 \%$ of retail prices on average for poultry snapshots. The picture is quite different for milk and beef. They constitute on average $57 \%$ of the retail price for milk, $114 \%$ for beef from extensive systems and $12 \%$ for beef from dairy systems. The exception is the Dutch dairy specialized system for which the GHG costs are only $19 \%$ for milk and $1 \%$ for beef of the retail price.

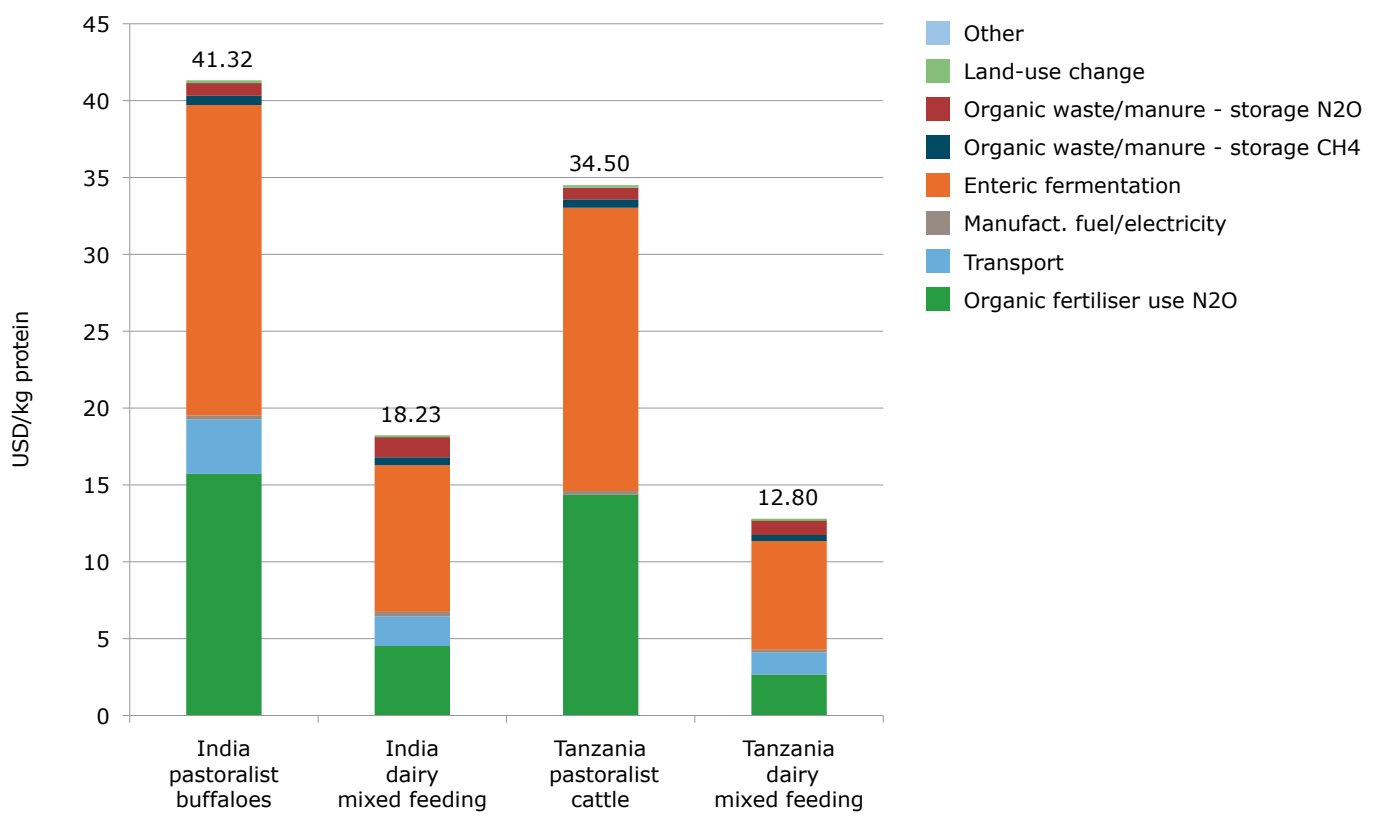

Figure 4.4 GHG externalities in pastoralist and mixed farming systems (USD/kg protein)

The pastoral systems in India and Tanzania produce double the amount of GHG costs per kg of protein compared to the respective dairy mixed systems of each country. This is due to the fact that mostly beef is produced in the pastoral systems apart from very little milk produced for home consumption. Opio et al. (2013) also remarked on this effect. Indian dairy generates more GHG emissions than the Tanzanian dairy system because of the higher milk production per cow in Tanzania.

When interpreting these results, note that most of the protein output in the dairy mixed systems is provided by milk, while in the pastoral system protein output primarily comes from beef production. In practice the ability to substitute milk for meat may have natural, social and economic limitations, which are discussed further in this report.

Some of the snapshots considered are comparable as they are able to export. These include the Netherlands industrial broilers, Netherlands dairy specialized and Brazil beef grazing with feedlot. Comparing these systems is valuable as they all supply animal protein to the international market. The Netherlands industrial broilers snapshot is representative of an 'international' poultry system, as it embodies an industrial method observed in large parts of the world including Brazil and the U.S., which are among the largest producers of poultry worldwide. 


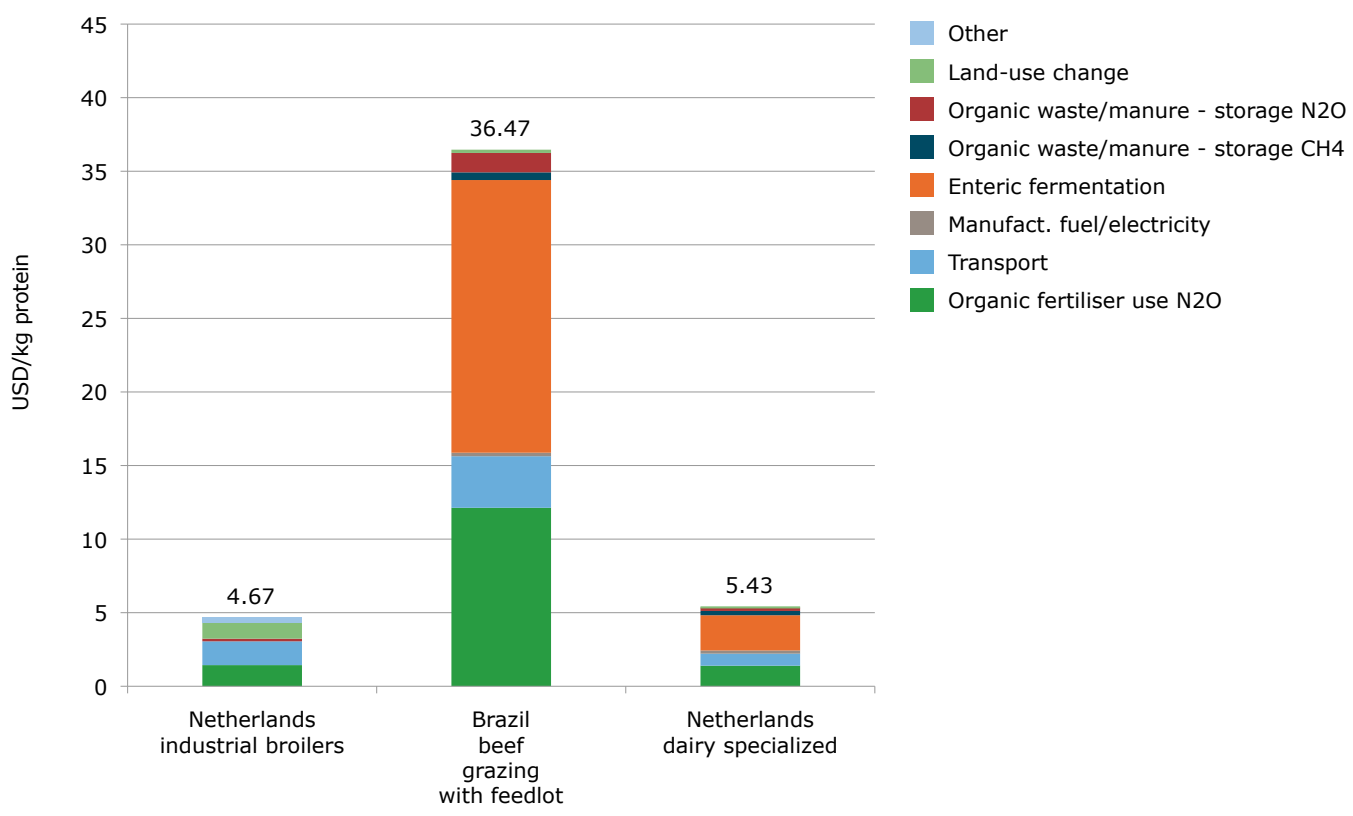

Figure 4.5 GHG externalities of systems able to export (USD/kg protein)

The Netherlands dairy specialized production system produces higher GHG costs per kg of protein than the Netherlands industrial broiler production system. Although GHG emissions from land-use change are relatively larger for industrial chicken systems (where $93 \%$ of the feed is imported vs $24 \%$ for the dairy system), the GHG costs are lower per kg of protein. This is mainly due to the absence of enteric fermentation and a lower feed conversion rate.

The Netherlands dairy specialized system's low carbon intensity is associated with its use of improved breeds and focus on animal health and nutrition standards, which lead to high productivity. The system is primarily designed to maximize milk production. A high replacement rate of milk cows in the herds results in high meat production. Total meat production per animal place in the Netherlands is comparable with the meat production in a beef system in Brazil. ${ }^{25}$ Notably, the beef systems in Brazil have a much higher GHG cost per kg of protein, due to the sole focus on meat production as opposed to meat and dairy and a lower production of meat per animal place than the Dutch dairy snapshot.

\subsubsection{Water pollution}

Water pollution costs are based on nitrogen $(N)$ and phosphorus $(P)$ nutrients surplus from excretion and synthetic fertilizer input at farm level leaching into water, which are estimated using IPCC-based leaching factors (IPCC 2006) and monetized with global coefficients for eutrophication cost, as presented in the bottom-up analysis methodology section. Water pollution from fertilizer use for crops used in feed at the supply chain level is beyond our scope, as tracing feed origin would require a considerable effort to collect data and the considered cattle snapshots rely more on grazing than on imported feed (see annex A).

The results indicate that nitrogen contributes far more to water pollution than phosphorus. The Tanzanian pastoralist system has the highest cost of water pollution per kilogram of protein produced among all snapshots at $4 \mathrm{US} \$ / \mathrm{kg}$ protein. This is mainly due to the low production per animal.

The Indonesian dairy mixed feeding system and the Dutch dairy specialised system snapshots have considerably lower water pollution costs than the rest of the snapshots at 0.06 and $0.12 \mathrm{US} \$ / \mathrm{kg}$ protein. 
For Indonesia the low impact is related to the relatively low use of external inputs (fertilizer and imported feed) that results in low leaching of nutrients. The Netherlands dairy specialized system has the highest amount of nutrients leached per hectare in all of the snapshots (figure 4.9) and the highest output in protein per ha. As a result the amount of water pollution costs per kilogram of protein produced are still low at $0.12 \mathrm{US} \$ / \mathrm{kg}$ protein. The considered beef oriented snapshots, which are extensive systems, have in general a higher water pollution cost per kg protein than dairy ones. This is mainly due to the lower protein production per hectare for beef compared to dairy.

Poultry systems are considered landless systems in the context of water pollution so $\mathrm{N}$ and $\mathrm{P}$ leaching is not quantified in those snapshots because manure is removed and used as fertilizer. Surpluses of nutrients in chicken manure are therefore not attributed to poultry production but to the users of the manure, namely arable farmers.

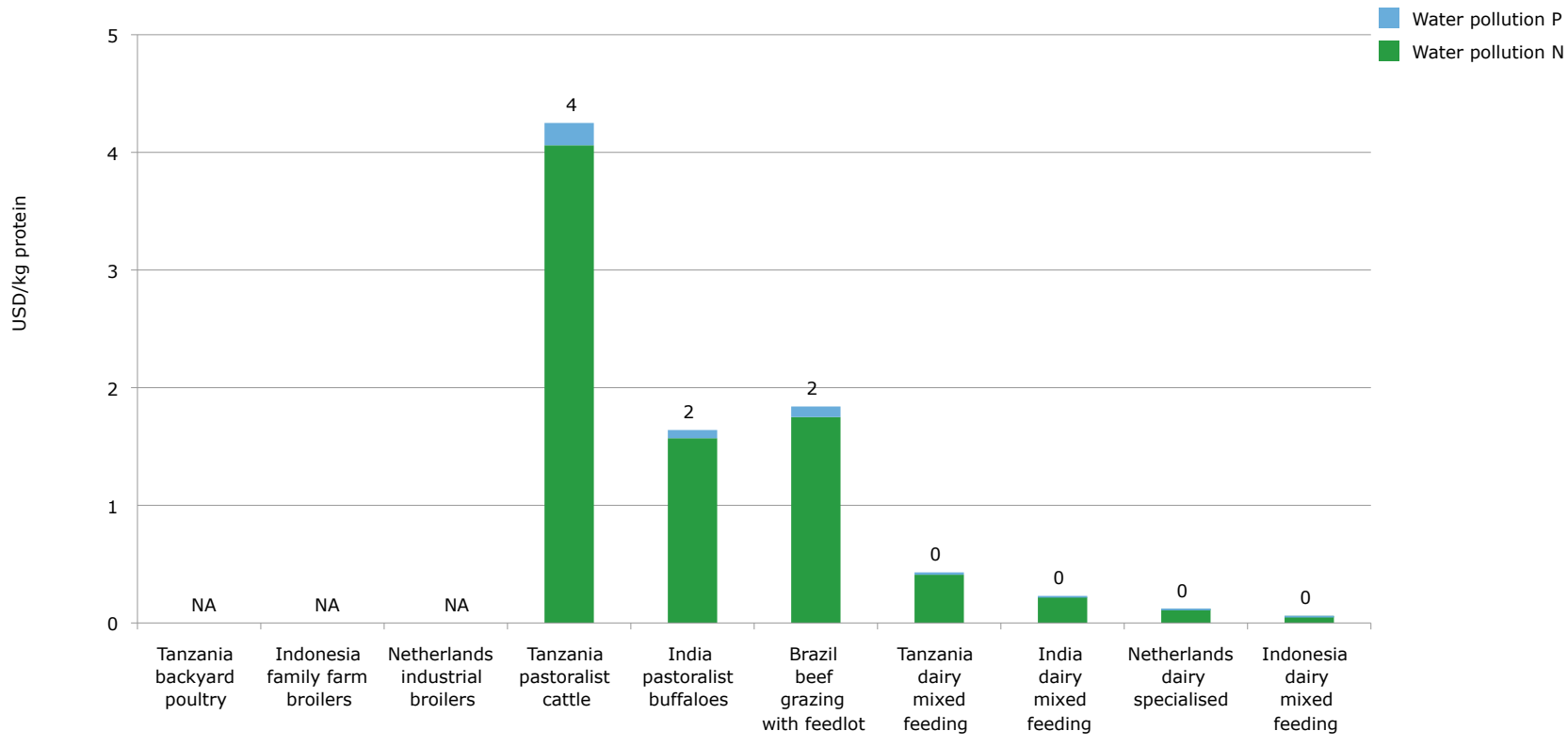

Figure 4.6 Water pollution costs for animal food products in the selected snapshots USD/kg protein

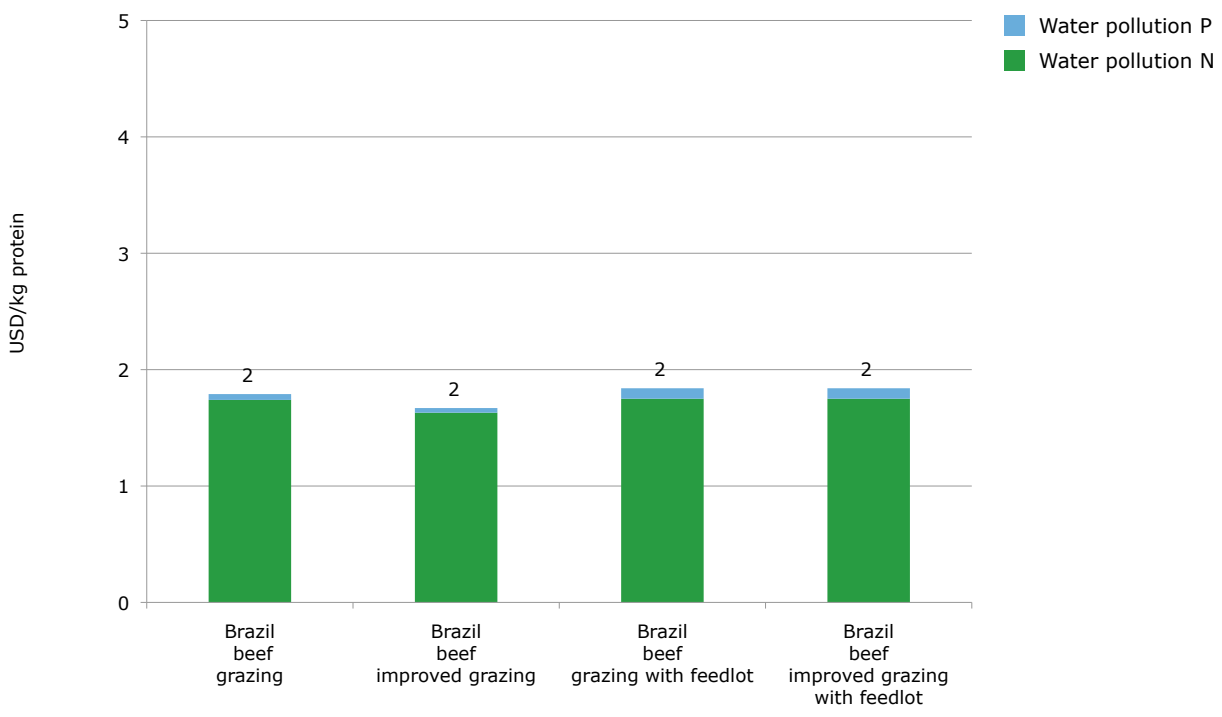

Figure 4.7 Water pollution costs for beef production in Brazil with efficiency improvements USD/kg protein 
A comparison between alternative Brazilian beef systems reveals that although improved pasture management reduces water pollution compared to pure grazing, complementing grazing with finishing in feedlots does in fact increase water pollution. This is due to the higher leaching of nutrients that is caused by manure in feedlots. The water pollution costs between the feedlot systems are similar because an increase in protein output also results in an increase in nutrient leaching per hectare, offsetting the gains in terms of USD/kg protein.

Water pollution costs for the Indian pastoralist buffaloes and Tanzanian pastoralist cattle snapshots are compared with the respective smallholder dairy system in the same country. The results indicate that costs are higher in Tanzania than in India. In both countries the dairy mixed feeding systems have lower costs per unit of protein produced than the pastoralist systems. This is primarily due to higher productivity of dairy mixed feeding systems. The leaching per hectare of dairy systems is quite high compared to pastoralist systems as can be seen in figure 4.9, but the higher productivity compensates for it resulting in lower water pollution costs when expressed per unit of output. The difference between dairy systems in Tanzania and India in biophysical (non-monetary) terms is due to a significantly lower use of fertilizer in Tanzania.

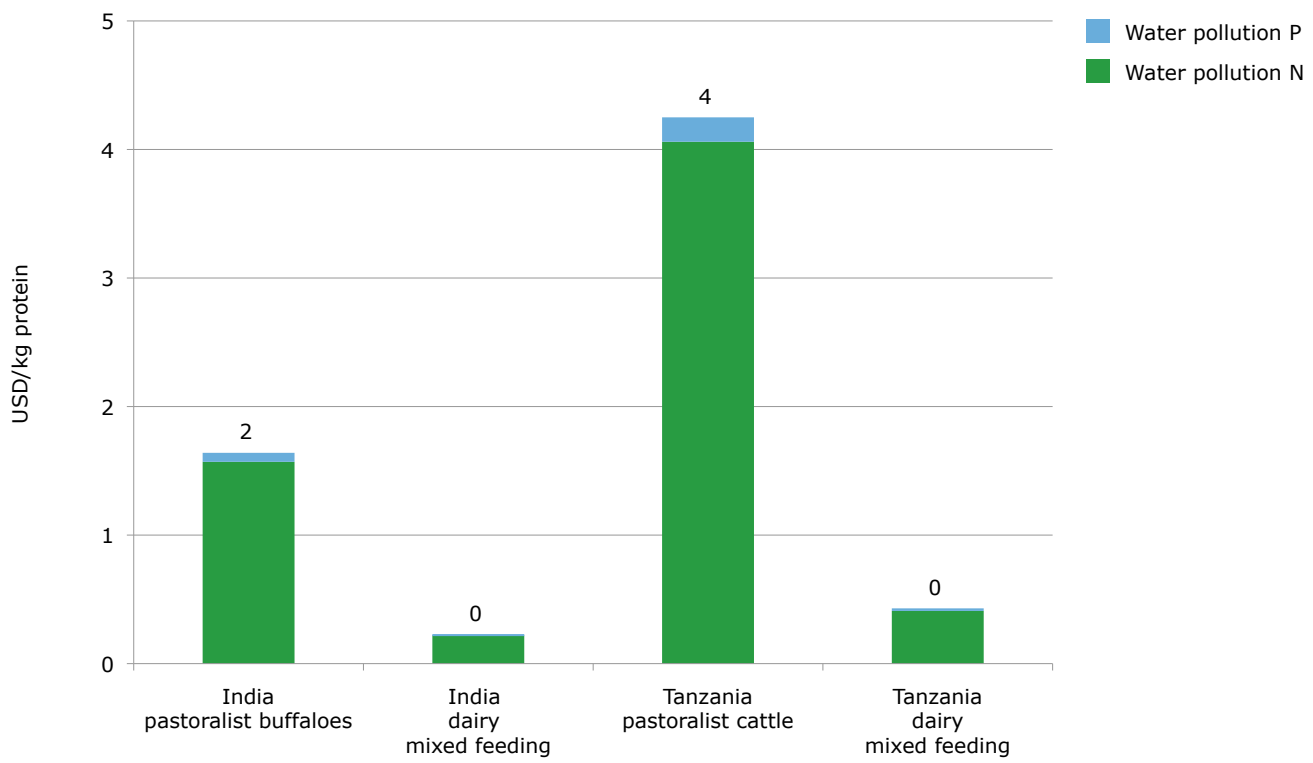

Figure 4.8 Water pollution costs in pastoralist and mixed farming systems (USD/kg protein)

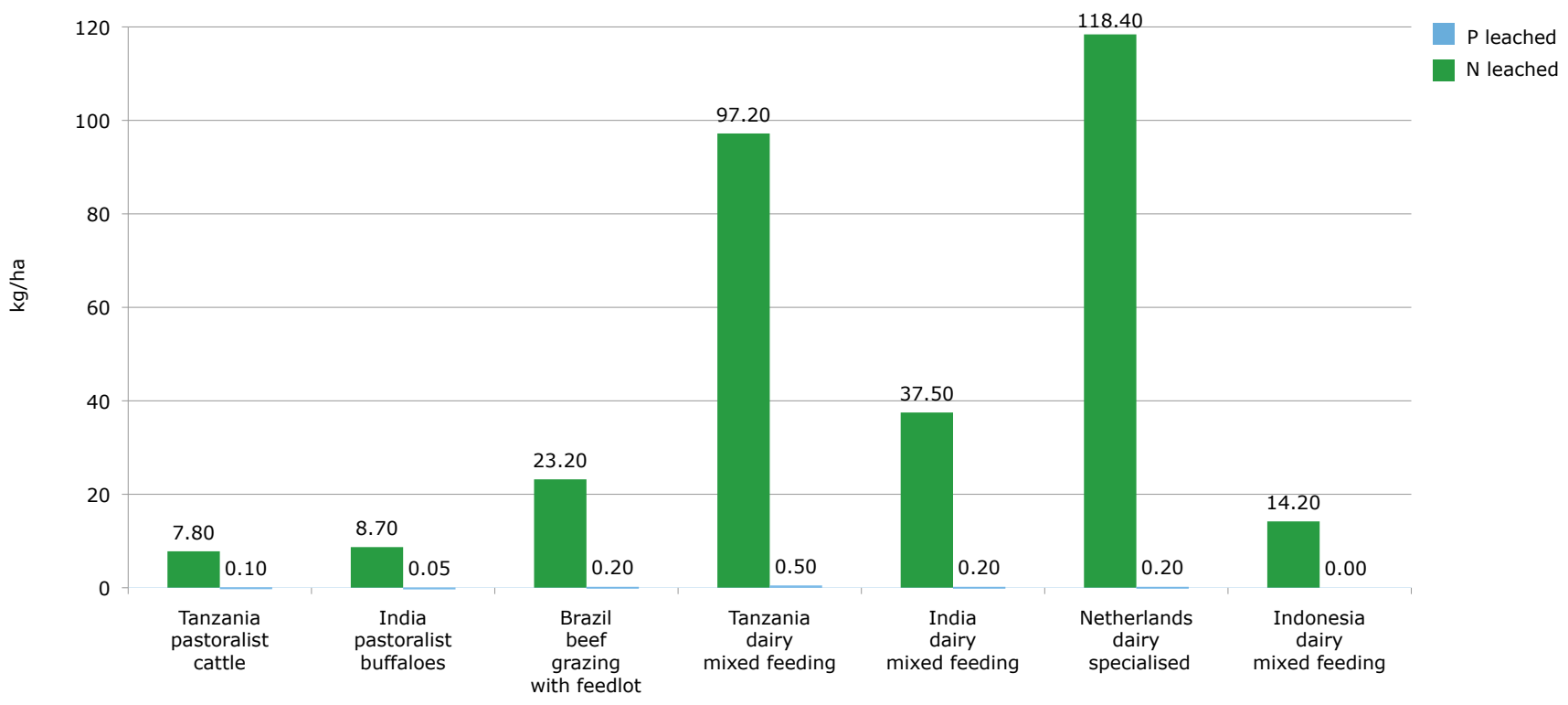

Figure 4.9 Footprinting $-\mathrm{N}$ and $\mathrm{P}$ leaching $(\mathrm{kg} / \mathrm{ha})$ 
The size of the water pollution externality in comparison with the retail price is shown in figure 4.10. Allocation, how much of the total emissions are attributed to milk as opposed to meat, plays an important role in determining the differences between external costs of the two products for each snapshot, and it is based on the share of milk and meat protein in the total output. Poultry systems are not shown because water pollution was not quantified, as explained earlier.
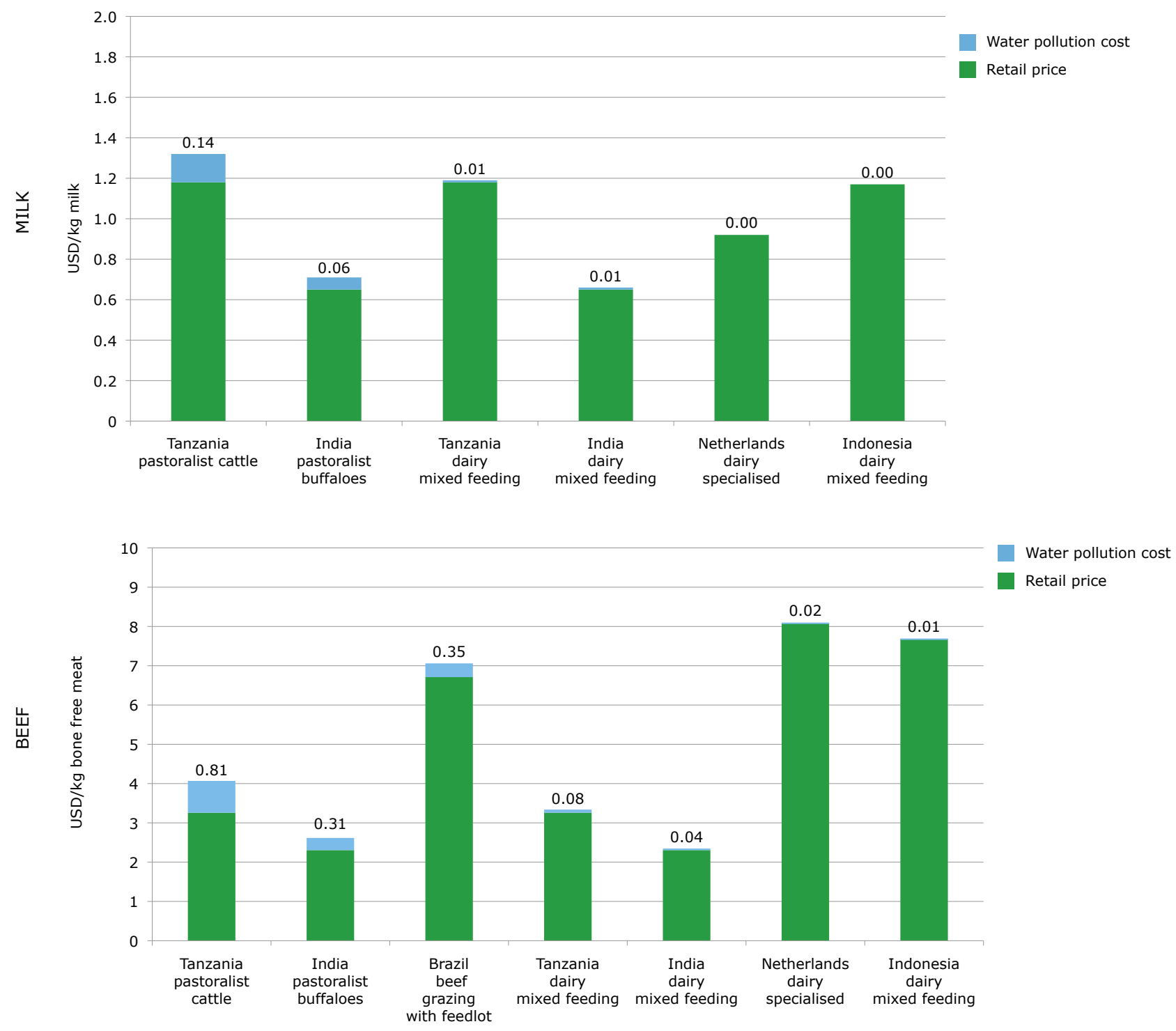

Figure 4.10 Water pollution externality compared to retail price for beef and milk production (USD/kg bone-free meat or $\mathrm{kg}$ milk)

The external costs of water pollution are generally higher for beef than for milk.

For milk, the ratio between water pollution costs and retail price has variations. Water pollution externalities are $1 \%$ or less of retail price for Tanzanian dairy mixed feeding system, India dairy mixed feeding system, Indonesian smallholder dairy systems and the Dutch specialised dairy system. The ratio is $12 \%$ for the Tanzanian pastoral cattle and $9 \%$ for the India pastoral buffaloes. The leaching of minerals per $\mathrm{kg}$ of protein produced drives the results in all snapshots. 
Similar conclusions can be drawn for beef, where the ratio between retail price and water pollution cost ranges from less than $1 \%$ to $5 \%$ for the dairy systems and reaches levels of 13 and $25 \%$ for the Indian and Tanzanian pastoral systems. The high levels for pastoralist systems is due also to the fact that almost no milk is produced by these systems, so the costs are entirely attributed to meat. The same applies to extensive beef production in Brazil, which does not yield any milk.

\subsubsection{Quantification of land occupation}

As with the other analyses, land occupation is expressed per $\mathrm{kg}$ of protein to facilitate the comparison of different animal products. Land occupation is not monetized for all snapshots because of the methodological challenges involved. Instead, results are here presented in square metres. Because not all land dedicated to agriculture or animal husbandry is the same, land occupation is divided between cropland, grassland grazing (with animals grazing mainly in fenced pastures), ranging (with animals covering large distances in non-fenced semi-natural grasslands) and roadside grazing. Distinctions between types of land use with different intensities are further analysed in section 4.3.4, in relation to the impact that livestock-related land occupation has on the original biodiversity.

In general, intensive systems occupy significantly less land than extensive ones per unit of output, because of lower feed conversion rates (less $\mathrm{kg}$ of feed per $\mathrm{kg}$ of growth or production) and higher production per hectare (due to higher inputs of fertilizers). Feed requirements, which determine feed conversion rates (FCR), are key factors for understanding land occupancy. Indigenous animal breeds and low digestibility feeds lead to higher FCRs, which results in higher land occupancy. Careful animal health management also has a positive impact on productivity and therefore on land requirements. These factors are reflected in the fact that there is generally higher land occupancy in developing countries than in developed countries. The effect is accentuated in regions with adverse climates and associated low-quality feed, such as in the drylands of Tanzania.
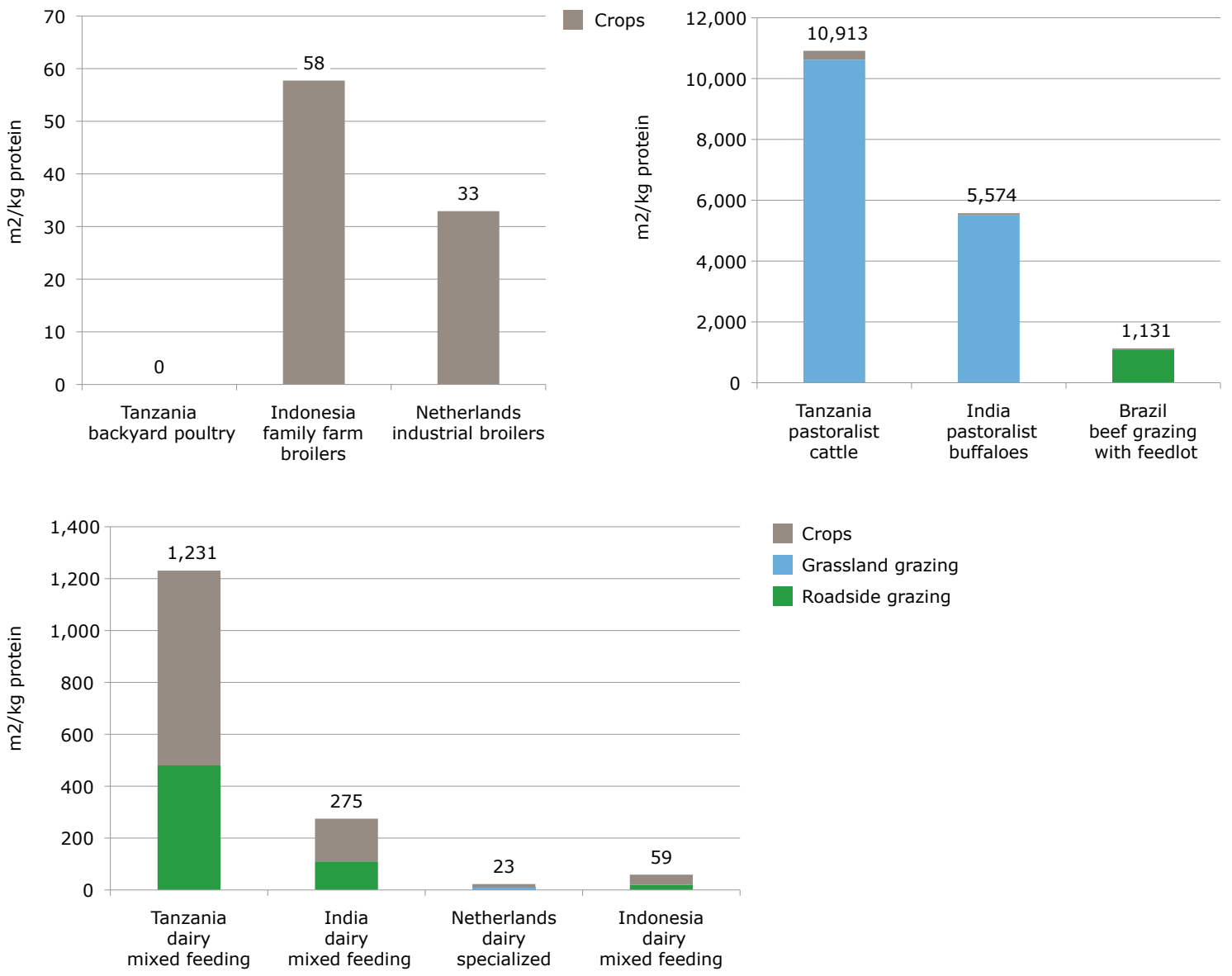

Roadside grazing

Figure 4.11 Land occupation - poultry, beef and dairy snapshots ( $\mathrm{m} 2 / \mathrm{kg}$ protein) 
The figures above (figure 4.11) compare all snapshots in terms of land occupancy per kilogram of protein. Poultry systems have the smallest land occupancy on average because of their low feed conversion rate. The Indonesian dairy mixed feeding and Netherlands dairy specialized systems also occupy relatively smaller amounts of land since they are more efficient in producing protein than pure beef systems. Pastoralist systems are distinguished from extensive systems, as they have much higher land occupancy due to low grass yields and low animal productivity. The Tanzanian pastoralist cattle in particular is an extreme example of an extensive system, and its land requirements are double that of the Indian pastoralist buffaloes, an order of magnitude higher than that of the Brazil beef grazing with feedlots snapshots and two orders of magnitude higher than the dairy mixed feeding systems. However, in pastoralist systems, livestock grazes on natural grasslands, so this livestock's occupation of the land is far from exclusive. Section 4.3.4 on land use and biodiversity and the in-depth case study on pastoralism in the Maasai Steppe (see chapter 5 ) refine this analysis by highlighting different impacts on biodiversity associated with different types of land occupation, and the benefits that local communities can extract from land given different land use or land management options.

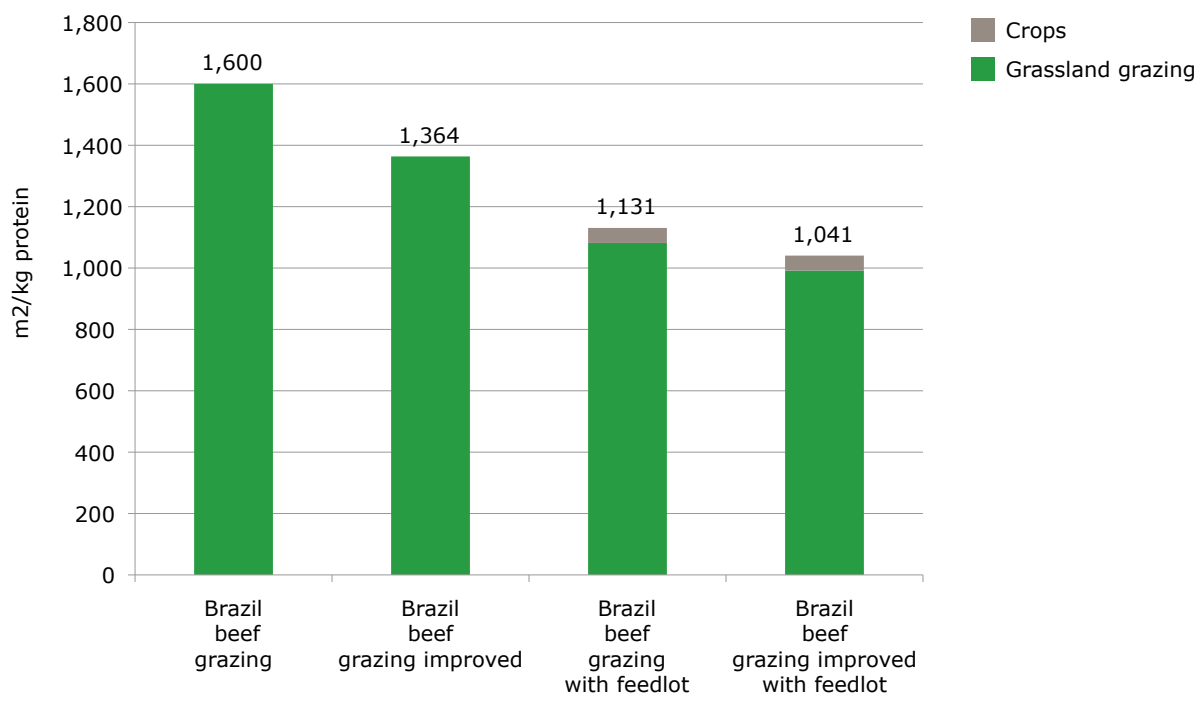

Figure 4.12 Land occupation - Brazilian beef production systems with different pasture management and finishing

Figure 4.12 compares different types of Brazilian beef production systems, including grazing, improved pasture grazing, grazing with feedlot and improved pasture grazing together with feedlot. This comparison is done to quantify how much more efficient the baseline snapshot of beef grazing with feedlot can be in terms of land occupation. Feedlot practices have the potential to reduce land use by $35 \%$ when combined, yet most of the nutrition for the animals (95\%) is still provided by grassland grazing.

Improved pasture management alone is less efficient than finishing in feedlots alone ( $14 \%$ as opposed to $29 \%$ reduction in land use).

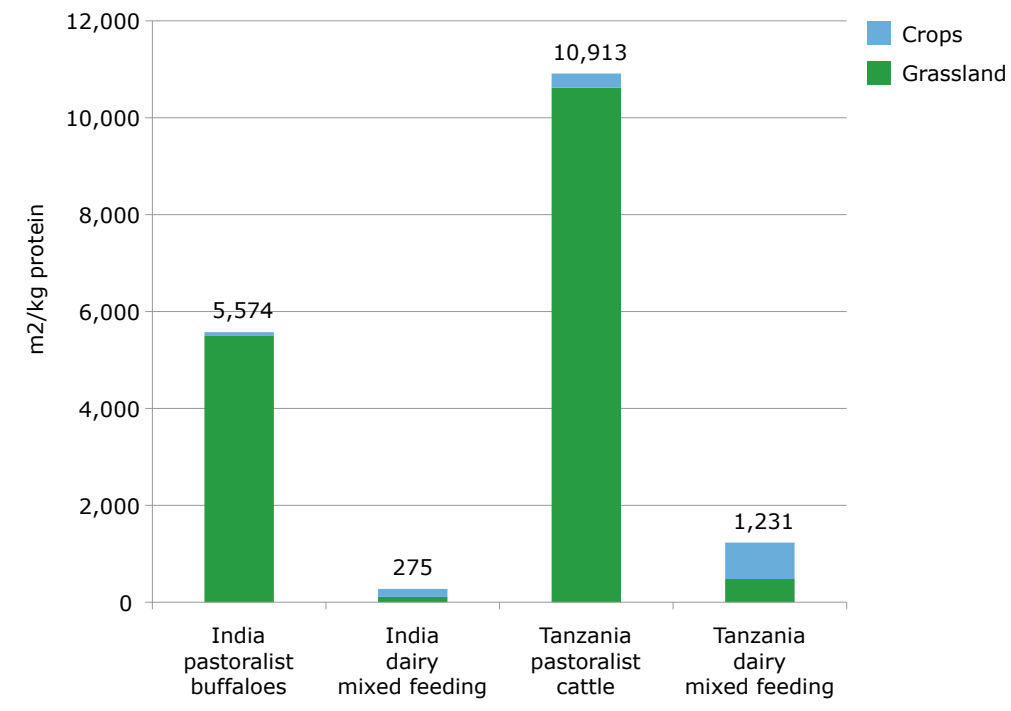

Figure 4.13 Land occupation - pastoralist vs dairy mixed 
We also compare Tanzanian pastoralist cattle and Indian pastoralist buffaloes along with the alternative system of dairy mixed feeding in each country. Tanzanian pastoralism, the system with the highest land occupancy requirement per $\mathrm{kg}$ of protein produced, has much lower productivity in milk than Indian pastoralism. Limited access to markets, feed and water in Tanzania constrain animal productivity to very low levels. The results show that dairy systems based on mixed farming have much lower land requirements, since they produce milk and meat instead of only meat and because they rely upon crop residues and co-products. The Tanzanian and Indian dairy mixed feeding systems differ with regard to feed quality and herd composition. This translates into a feed conversion efficiency that is twice as high in India as in Tanzania. Additionally, crop yields in Tanzania are much lower than in India, resulting in much higher land occupancy. Crop yields in India increase with the application of fertilizers, but this also results in higher carbon emissions. This could be related to the fact that decreasing land use by increasing yield is a trade-off between land and carbon emissions, as it increases fertilizer-related emissions. Other factors, such as feed quality, animal health or carbon sequestration, can play an important role in reducing overall GHG emissions efficiency, however.

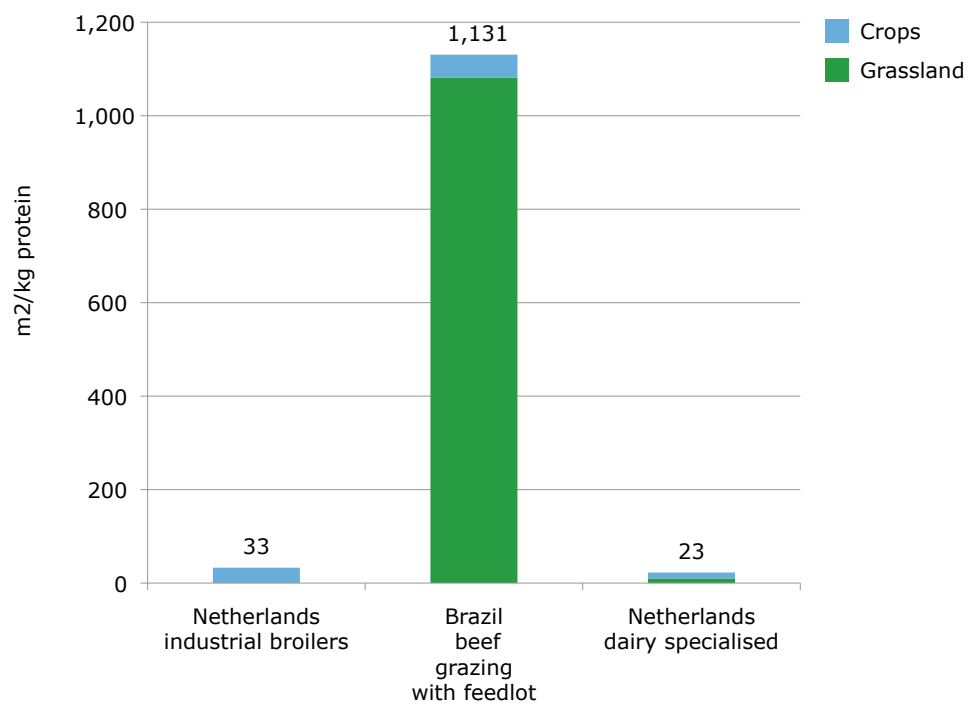

Figure 4.14 Land occupation - systems able to export

Lastly, figure 4.14 compares key animal husbandry systems that are able to export, namely the Brazil beef grazing with feedlot system, the Netherlands dairy specialized system, and the Netherlands industrial broilers system. The two intensive Dutch systems result in land occupancy that is 35-50 times smaller compared to proteins produced by extensive beef systems. Interestingly, the Netherlands dairy specialized system is slightly better than the Netherlands industrial broilers system.

These results show that some types of production systems have much lower land requirements than others, and this difference can span one or more order of magnitude.

\subsubsection{Land use and biodiversity}

Land-use and climate change are generally considered drivers from farming systems with the strongest impact on biodiversity and ecosystem services (Newbold et al., 2015). The impact of the poultry and cattle-based livestock systems on biodiversity in the snapshots is based on the approach outlined in section 2.4.4 with the information on greenhouse gas emissions (section 4.3.1) and land occupation (section 4.3.3) as quantified for the different snapshots. First the impact (1-MSA) is assessed per area (ha) of grazing land (figure 4.15) or per area cropland (figure 4.16). The impact on biodiversity per ha of production system is smallest for the pastoralist systems and is higher for the more intensive and feed-based production systems. To provide an estimation of the value of this biodiversity for local populations, chapter 5 contains a case study where the economic implications for natural capital conservation of the Tanzanian pastoral system are examined more in detail. 
The poultry systems are only based on feed production. Subsequently the MSA loss per ha system is multiplied by the land-occupation area per kg protein (section 2.4.4) to get a quality adjusted area (MSA.ha kg-1 protein, 1 MSA.ha is equivalent to one hectare of land that has lost $100 \%$ of its diversity) (figure 4.17) a trade-off between intensity and efficiency of the production system becomes apparent. The results show that the pastoralist systems have the smallest impact per unit of area, but because they need a relatively large area per kg protein produced (section 4.3.3) their overall impact per unit of produced protein remains large (figure 4.17). The impact of feed production is relatively large per unit of area of production (figure 4.16). The overall impact therefore depends largely on the amount of feed used as input per kg protein as output (figure 4.17).

The low impact per area for the Tanzanian system indicates that these systems may better protect ecosystem functions and integrity locally, but at the same time the large areas needed for production have a larger overall biodiversity impact on overall biodiversity. Any sustainable intensification of the smallholder systems should try to combine the low impacts per ha with higher protein productivity.

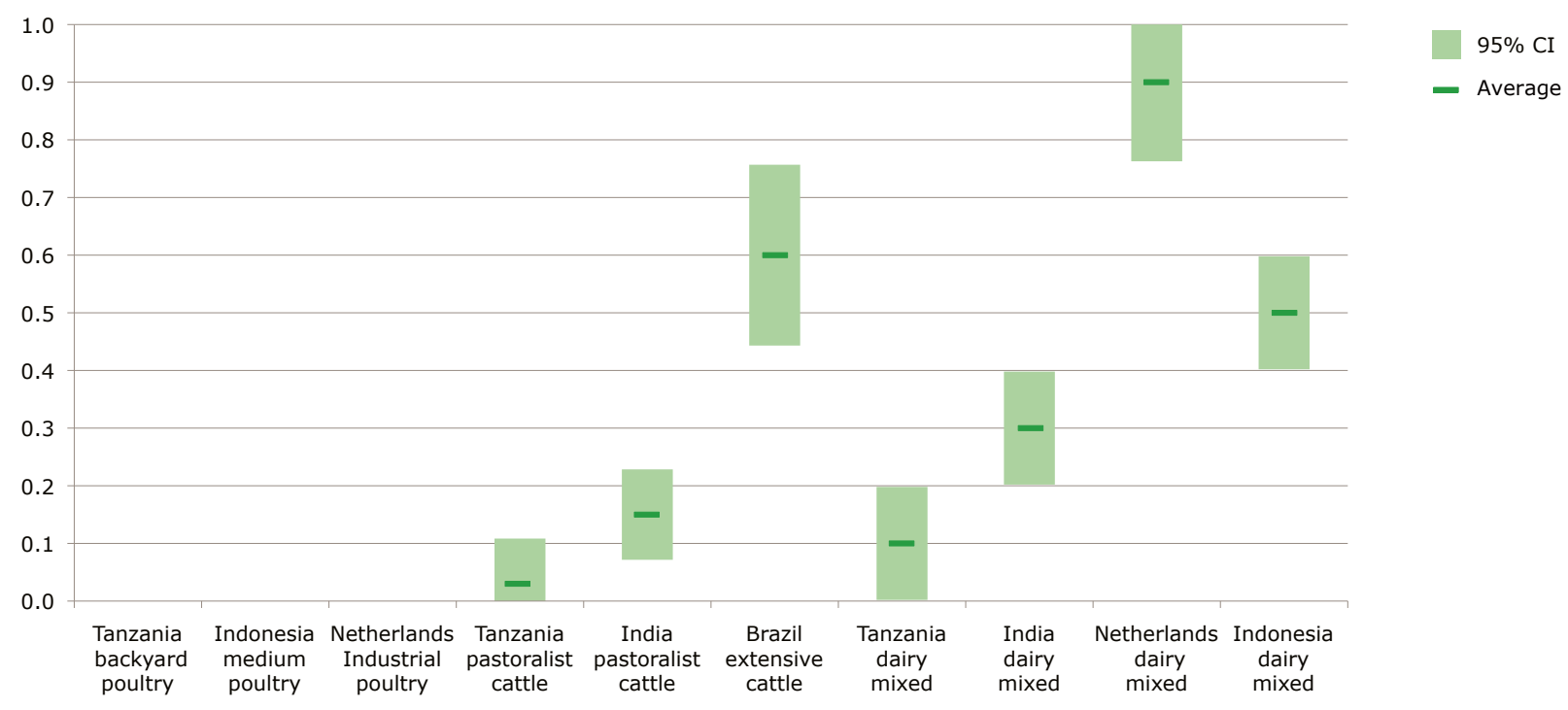

Figure 4.15 Biodiversity impact per ha grazing land for the different snapshot systems. Note: the impact on biodiversity is expressed as the loss of MSA (1-MSA). The bars indicate the $95 \%$ confidence interval of the estimated MSA loss values; the lines indicate the average value, both based on Alkemade et al., 2009; Alkemade et al., 2013). The three poultry systems are considered to have no direct land-use effects through pastures.

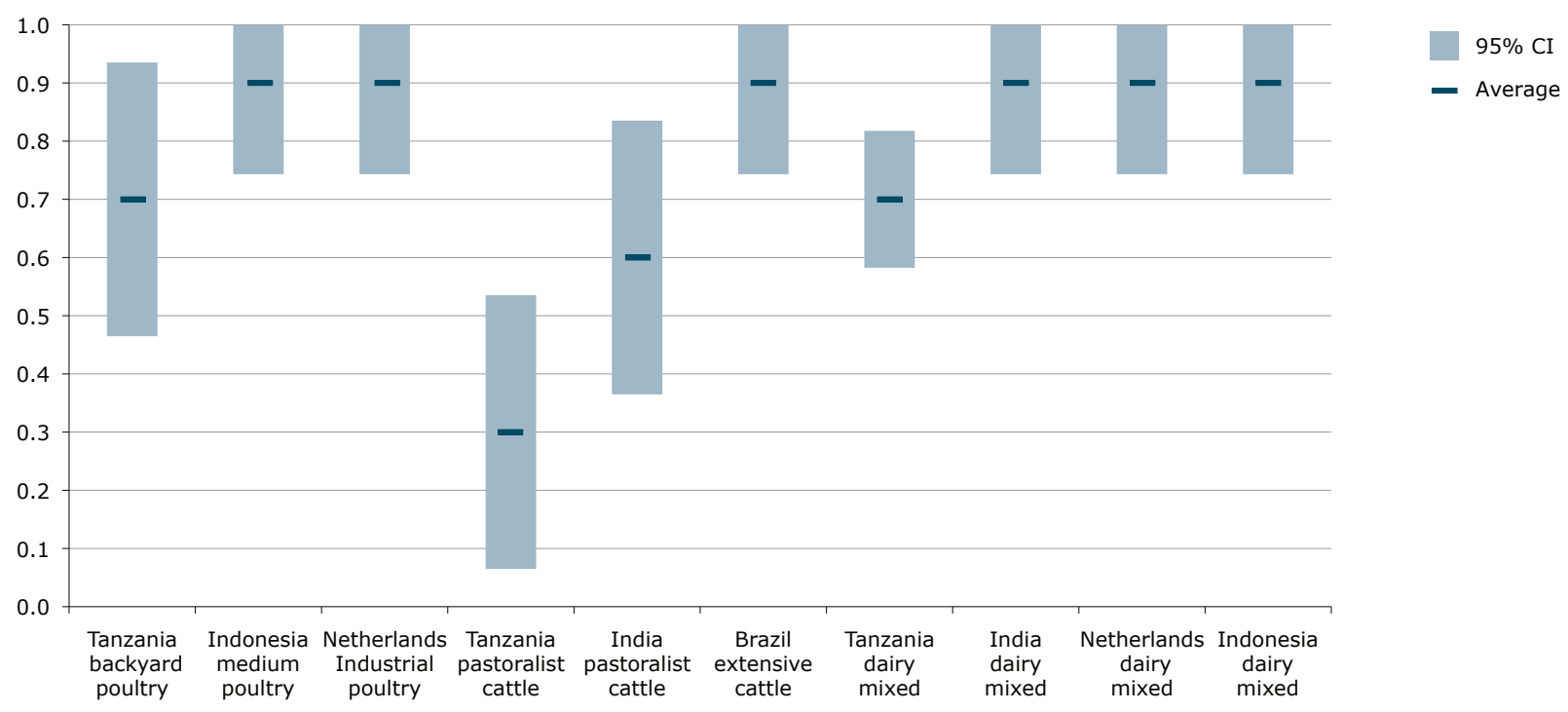

Figure 4.16 Biodiversity impact per ha cropland used for feed production and impact of the use of land for cropland on biodiversity for the different snapshot systems. Note: Impact on biodiversity is expressed as the loss of MSA. The bars indicate the $95 \%$ confidence interval of the estimated MSA values; the lines indicate the average value. 

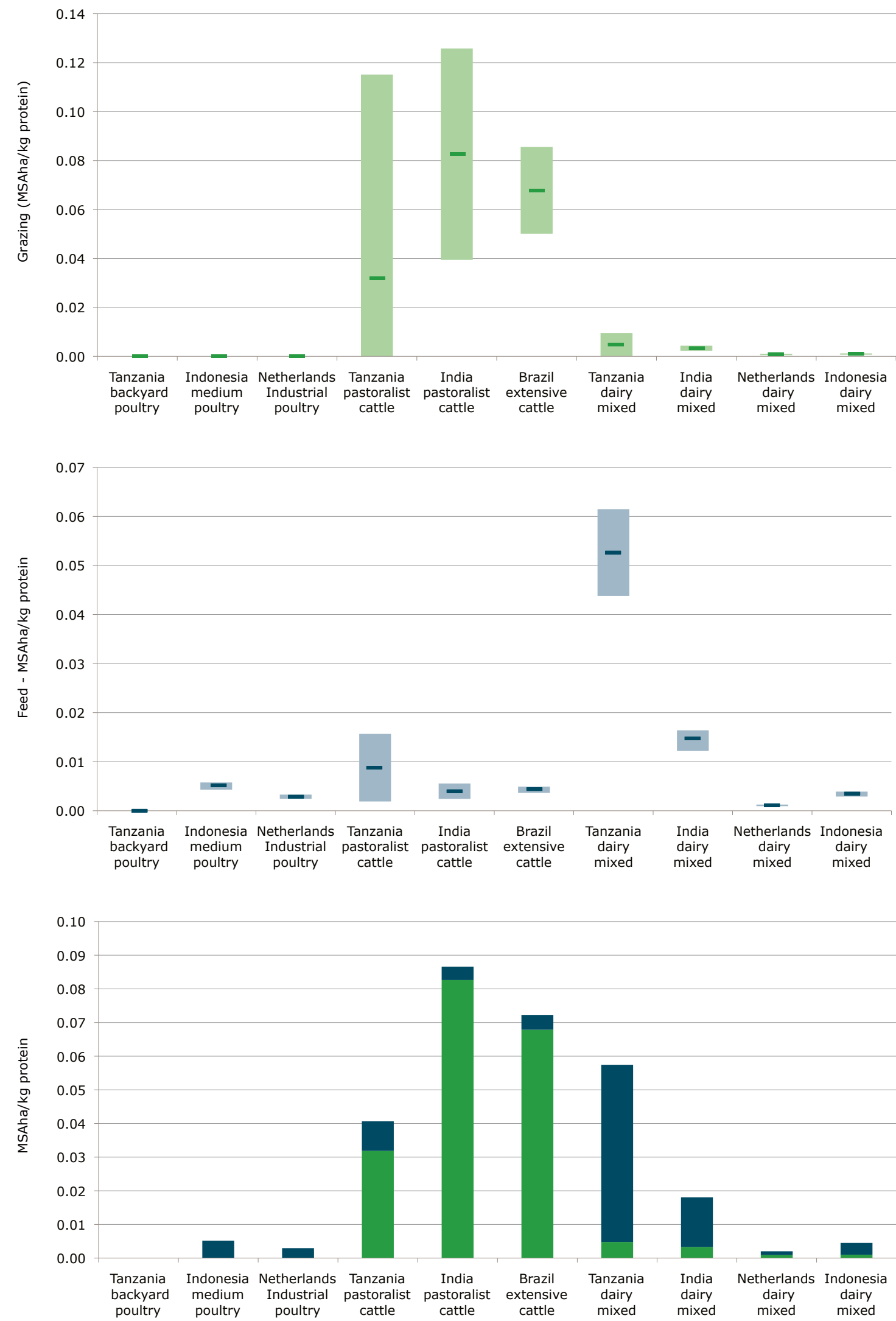

Figure 4.17 Total biodiversity footprint for the different snapshot systems (MSA.ha kg-1 protein; the area needed per kg protein $\times$ MSA impact, i.e. a value of 0.10 indicates that for the production of $1 \mathrm{~kg}$ of protein the equivalent of 0.1 ha loses $100 \%$ of its biodiversity). A) footprint for the pasture area; B for the area needed to produce feed; and C) for total land use (pasture and feed). In A and B the bars indicate the $95 \%$ confidence interval based on that of the estimated MSA impact values (i.e. only 1 estimate of land-use areas is included); the lines indicate the result with the average MSA impact value. 
The impact of GHG emissions shows a similar trade-off between intensity of production and efficiency of the production system (figure 4.18).

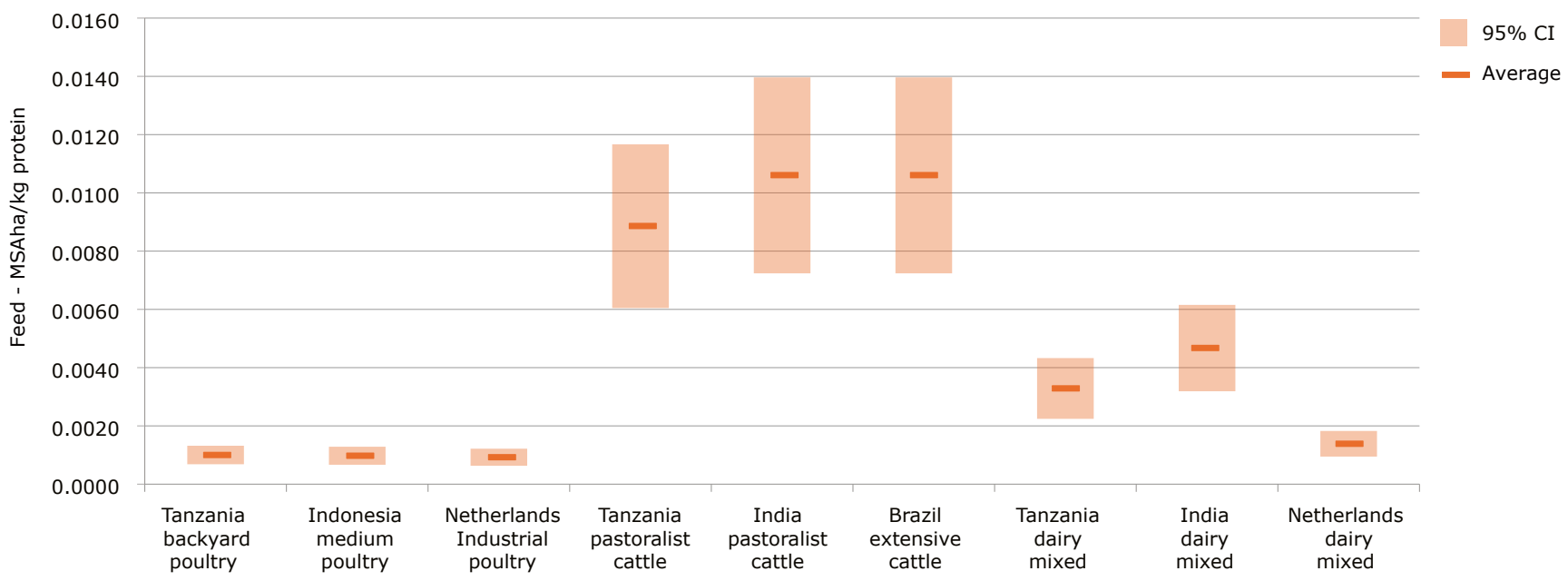

Figure 4.18 Climate-change footprint based on the total GHG emissions in the different livestock production systems

\subsubsection{Blue water dependency}

A dependency is an input that ecosystems provide to agricultural systems. Examples of dependencies are green water, blue water, soil fertility or pollination, all important inputs to farming that are supplied by ecological processes. In this section we look in depth at quantifying the value of one of these dependencies in the considered supply chains of animal proteins: blue water use, or irrigation, for producing feed for livestock.

Blue water use occurs primarily in crop production (Mekkonen and Hoekstra, 2010). Combining data on feed requirement, trade of crops, regional yields and farm economics makes it possible to quantify irrigation water use per unit of animal protein produced and monetize the degree of reliance on this natural capital input of animal husbandry systems.

The valuation of blue (irrigated) water is based on the difference in farm profit as a result of blue water use. We define this additional profit due to irrigation as residual profit. As such it does not represent damage to the environment, as is the case for nutrient and GHG emissions, but rather a valuation of the degree to which animal husbandry activity relies on this form of natural capital. To illustrate this, if one looks at the retail price of any of the animal products, the amounts below represent the share of the value of that product that can be attributed to blue water.

The results show that only four of the considered snapshots actually benefit from irrigation water: Indonesia family farm and Netherlands industrial broilers for poultry, Indonesia and India dairy mixed feeding systems for cattle. The latter system is the one with the highest dependency on blue water per $\mathrm{kg}$ of protein produced, because crops in India are highly irrigated. Poultry systems that depend on imported feed also depend on blue water to an extent, although these dependencies are not as high because part of the crops, such as maize and soybeans, are primarily grown under rain-fed conditions. A comparison of retail prices to the water dependency value does not have the same meaning as for negative externalities such as GHG and water pollution. Water dependency represents the value added by blue water to the overall product value. This is a very small part of the products' retail price, as most of the crops are grown on green water: between $0.2 \%$ and $1.5 \%$ for milk and between $0.2 \%$ and $2.5 \%$ for meat. It is worth mentioning that in this analysis blue water footprints were attributed fully to main crops, rather than crop residues, following the approach defined by Mekkonen and Hoekstra (2010), which is assumed to be the accepted method for blue water footprinting. This allocation method differs from the ones used in other parts of this study, where allocation based on feed digestibility was used. If one would instead decide to allocate part of the water footprint to crop residues, the results could change significantly in three smallholder dairy snapshots where crop residues are about $70 \%$ of total feed composition (Tanzania dairy mixed feeding, Indonesia dairy mixed feeding and India dairy mixed feeding). 


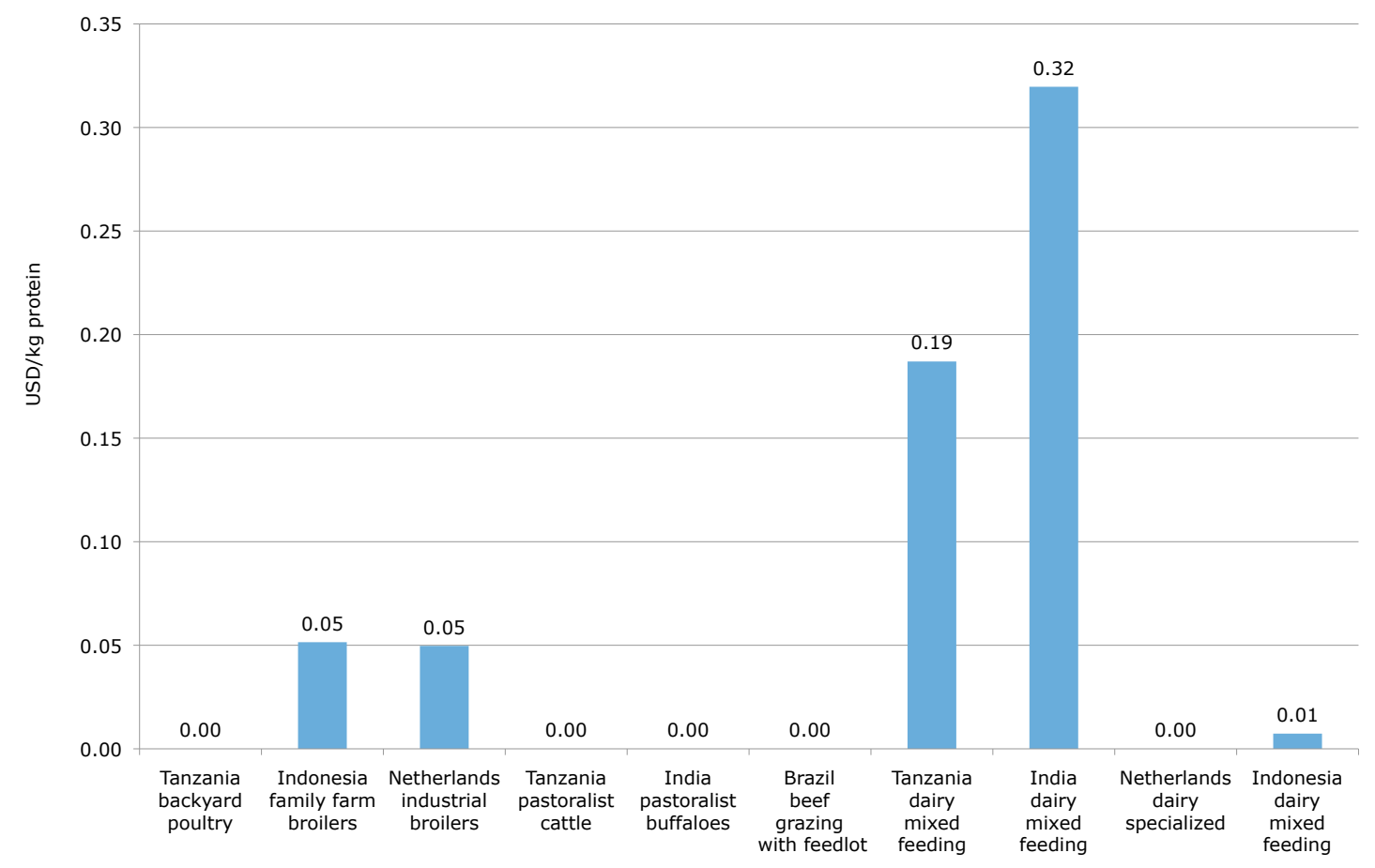

Figure 4.19 Value of blue water (USD/kg protein)

\subsection{General results bottom-up valuation}

The results presented up to this point provide an overview of the externalities of the considered snapshots of animal husbandry in relation to GHG emissions, water pollution and land occupation, as well as a quantification of their dependency upon blue water supplies.

Comparing production systems across regions and species, natural capital costs fall in the range of $3 \%-161 \%$ of retail prices for GHG and $1 \%-5 \%$ for water pollution across all snapshots, where the variability is explained by environmental performance and market prices of animal products. Dependency on blue water is found to be very small for all snapshots, between 0 and $2.5 \%$ of retail price. The main conclusion is that poultry production can provide animal proteins at a lower environmental impact than beef or dairy.

There is one notable exception to this general conclusion: Due to its high efficiency, dairy production in the Netherlands dairy specialized system (snapshot 9) has natural capital costs that are in the same order of magnitude as poultry for land use and GHG emissions, as opposed to the other cattle systems studied, which generally have higher impacts. It should be emphasized that the system in question is a common Dutch dairy system on peat soils with good practices regarding mineral management.

The analysis of the other three dairy systems showed a large variability of results. These are smallholder dairy systems that rely mainly on crop residues and roadside grazing for feeding. Their impacts in terms of GHG, water pollution and land occupation are the result of the interaction of many local parameters. The most important are the health conditions of animals, the quality of feed, manure management practices and the amount of synthetic fertilizer used.

Looking at the considered beef systems, namely the Brazil beef grazing with feedlots, Tanzania pastoralist cattle and India pastoralist buffaloes, we see that GHG emissions and costs of water pollution are similar.

In Brazil efficiency improvements were compared for beef ranches. Where grazing is combined with a 
fattening period or finishing in feedlots, it is shown to lead to a higher cost of water pollution, but a higher efficiency in terms of land occupation and a lower natural capital cost in terms of GHG emissions. Another major difference between beef systems lies in their land-use profile. Pastoralist systems use a much larger amount of land per unit of output, but they use it in a non-exclusive way which leads to lower effects on biodiversity. Pastoralist systems can extract value from the land on which they are based without affecting biodiversity and the internal value of natural capital. What this means in economic terms is further elaborated in the Maasai Steppe case study in chapter 5.

Within poultry, all the three variants studied are considered to be neutral in terms of water pollution and found to be similar in terms of GHG, although intensive poultry production is more efficient than medium-sized industrial farms in terms of land and water use. Backyard chicken production also has low land use and low emissions since it relies on scavenging, swill and second-grade feed products. Interestingly this system appears to be efficient in terms of natural capital costs, although the possibility for scaling it up are limited by the availability of waste. Poultry farms are not considered to cause water pollution as manure is usually removed and used by other arable farms.

Finally, the analysis of the dependency of these animal husbandry snapshots on blue water for irrigation shows that this dependency is limited. The considered snapshots rely mainly on rain-fed crops, whether the feed is grown locally on farms or imported, with the exclusion of mixed farms in India.

Considering the decision context described at the beginning of this section, the following insights can be gained based on the results of the assessment:

- Policy-makers and consumers alike can look to poultry and some forms of intensive dairy farming as the sources of protein with lowest natural capital impact. Dairy systems can supply natural capital-efficient protein not only in the form of milk, but also meat from surplus calves and of culled animals.

- In regions like East Africa and India, pastoral and smallholder cattle systems with a different focus on beef or milk, a varying level of intensity and reliance on inputs co-exist. Here there is a trade-off between lower water pollution, GHG emissions and land use in dairy farming vs conservation of biodiversity, and therefore other forms of natural capital value, in pastoralist systems.

- Pasture management. In extensive beef production in Brazil, improved pasture management can lead to lower natural capital costs and higher output efficiency.

The results corroborate the main conclusions from the top-down analysis and add granularity by considering different production systems and using mostly local data. The deviations in the results of the two assessments in specific cases are explained by this difference in scope and data sources used. A detailed comparison of the two assessments can be found in annex $B$.

A more in-depth discussion of the relevance, implications and limitations of the results of this quantitative impact assessment and valuation is provided in chapter 6.

\subsection{Key findings bottom-up analysis}

\section{Overall findings}

- The environmental externalities of animal protein production are a large invisible cost. The comparison of carbon externalities with the retail price of livestock products shows that these vary widely from place to place and can account for $1 \%-164 \%$ of retail price for beef, 3\%-161\% for milk and $19 \%-37 \%$ for poultry meat. Water pollution costs fall within a range of $1 \%-25 \%$ of product prices. This implies that society as a whole nevertheless pays a significantly larger price due to animal protein consumption.

- Beef farming has much larger natural capital costs compared to poultry farming, and mixed dairy farming, which also produces beef, has lower external costs than pure beef farming. This holds for all the environmental impacts considered, namely greenhouse gases (GHG), water pollution and land occupancy.

- Chicken meat production requires the smallest amount of land per unit of animal protein produced, because of its low feed conversion rate and absence of grazing. Dairy mixed systems also occupy relatively smaller amounts of land, especially where productivity is high or reliance on pasture grazing 
and imported feed is low. Extensive cattle systems result in the highest land-occupancy as their primary source of feed is pasture grazing. Land occupancy, however, can better be understood alongside the impacts on biodiversity and local communities that each production system has within its specific region.

\section{Snapshot specific findings}

- The production of beef as a 'side' product of intensive dairy farms with a high animal replacement rate is an alternative comparable to poultry in terms of the low impact on natural capital. This system, explored in its Dutch variation, appears to have land occupation and GHG emissions costs comparable to poultry, due to the system's high efficiency. There are two important caveats to this conclusion: the first is that the quality of meat produced in this system may not be comparable to that of pure beef-focused extensive systems, and it is more suitable for ground meat products. The second is that due to the high animal density and import of nutrients, this system has a very high nutrient load per hectare, the largest of all seven beef and dairy snapshots.

- The study of alternative beef systems in Brazil shows that improved pasture management and finishing in feedlots can reduce GHG natural capital costs up to $20 \%$. Looking at water pollution externalities it is found that while improved pasture management reduces water pollution, finishing in feedlots increases it compared to pure grazing systems.

- Backyard chicken rearing is found to have an environmental profile similar to that of more developed poultry systems, in terms of GHG emissions and water pollution, while it provides animal proteins at a lower cost in terms of land occupation and blue water use.

- Pastoralist systems generally have lower natural capital efficiency than other cattle systems, and land requirements are especially high. However, as opposed to feed-based or pasture-based systems, pastoralism can reap benefits from semi-natural ecosystems without negatively affecting biodiversity and natural capital, as highlighted by the in-depth case study on pastoralism and landscape preservation in Tanzania.

\section{Biodiversity impacts and dependencies of livestock production}

- Livestock has both direct and indirect impacts on biodiversity. The direct impacts through trampling and grazing and defecation appear to be smaller than the indirect impacts through land-use change (deforestation) and intensification of the land use creating homogeneous pastures for grazing and croplands for feed production, and climate change resulting from emissions of methane and other greenhouse gases.

- In poultry, and more intensive industrial-scale livestock production systems the relation with land use and its impacts is more obscure. Although these systems are sometimes called "land-less" production systems, this is a misleading term. These systems still rely on (distant) cropland for production of the concentrated feed they import, spatially disconnecting the livestock and part of its biodiversity impacts.

- Intensification of livestock production is an important trend resulting from the increasing demand for animal protein. Intensification involves a further concentration of resources (financial, labour and nutrient inputs) to produce more livestock on the same unit of land. As a result intensification can influence livestock's impact on biodiversity (and natural capital) in different ways. Locally the impact of more intensive production will increase, while at the same time demand for feed will increase leading to higher distant impacts. If, however, this increase in intensity is accompanied by an increased efficiency of production (i.e. more kg of protein - or meat or milk, or eggs - per unit of inputs) then the overall biodiversity impacts per unit of product of protein may decrease. Because increasing efficiency is not always possible and is inter alia depending on local growing conditions, this does not mean that intensification is a solution under all circumstances. Moreover, the low impact per area for the smallholder systems indicates that these systems may better protect ecosystem functions and integrity locally, but at the same time the large areas needed for production have larger overall biodiversity impacts. Any sustainable intensification of the smallholder systems should try to combine the low impacts per ha with higher protein productivity. 


\section{Animal and human health}

- There is variation in the use of antibiotics within and between species

- Zoonosis exists in all regions and animal production systems. The impact of food-borne diseases is more or less unknown. 


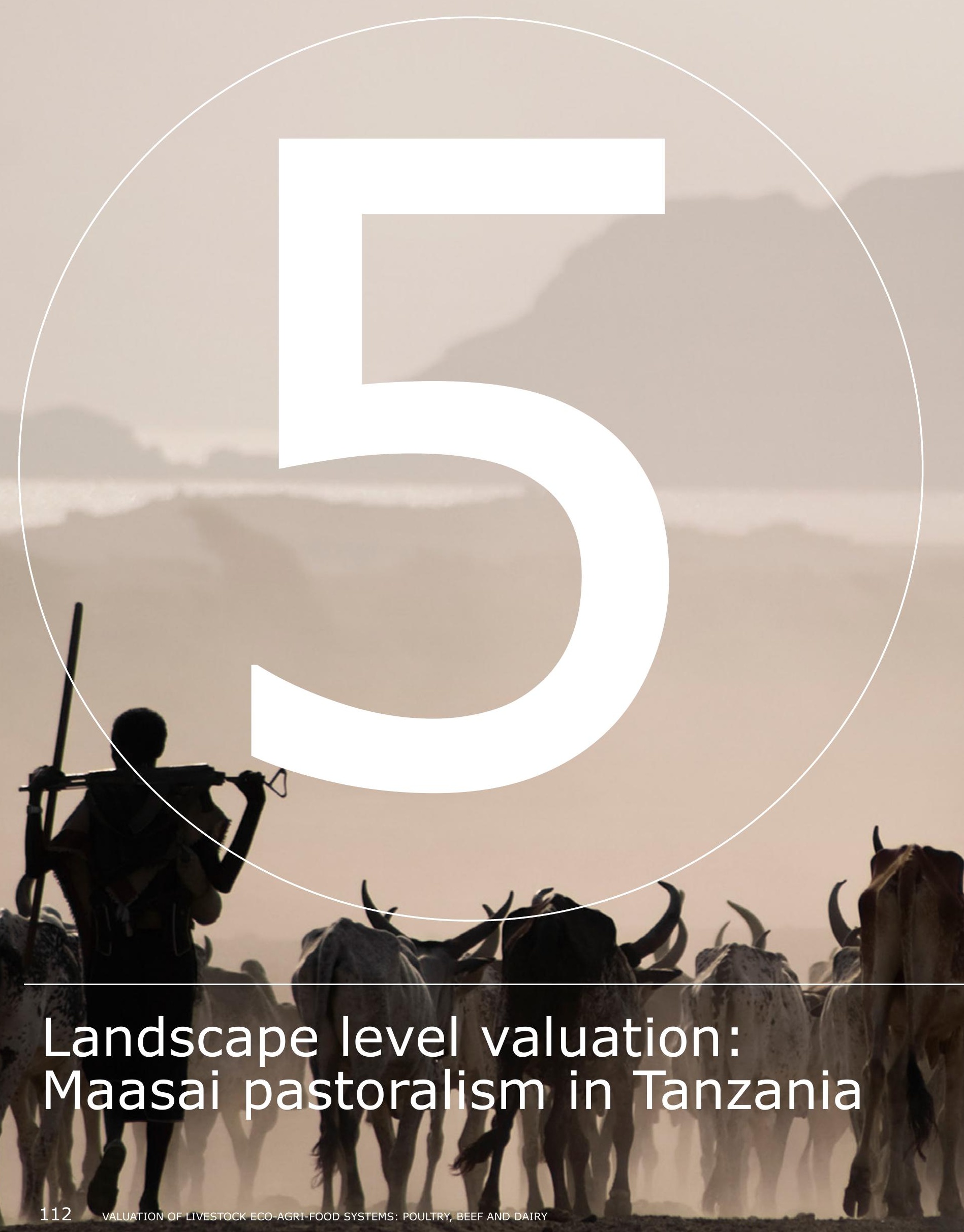




\section{1}

Introduction

$\boldsymbol{\theta}$

\section{2}

Context: the challenges of land conversion in the Maasai Steppe

$\nabla$

\section{3}

Impact measurement and valuation approach

$\nabla$

5.3 .1

Decision context

\section{3 .2}

$\boldsymbol{\nabla}$ Impact measurement $\boldsymbol{\nabla}$

\section{4}

Results

$\nabla$

\section{5}

Carbon stocks

$\nabla$

\section{6} Interpretation

$1 \quad r$

$r$

5.6 .1

Relation with the bottom-up snapshot analysis

$\nabla$

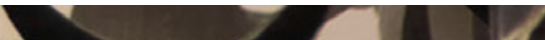

5.7

Key findings in-depth study Maasai Steppe

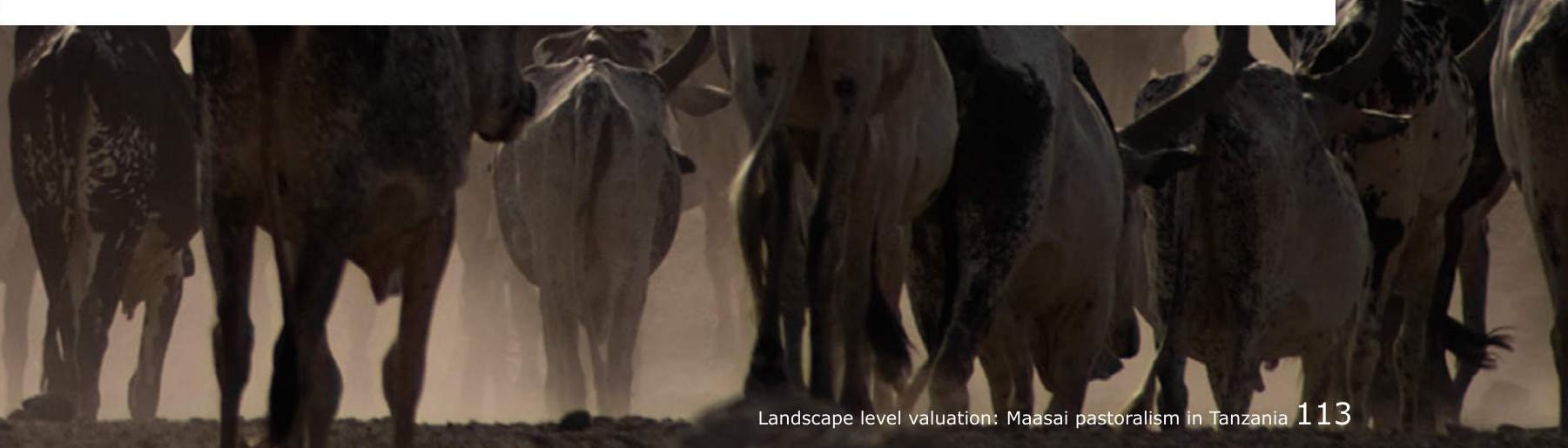




\section{Landscape level valuation: Maasai pastoralism in Tanzania}

\subsection{Introduction}

The snapshot valuations in chapter 4 focus on a selection of impacts and dependencies along the supply chain. One dimension that has not yet been addressed is the value of livestock systems in managing landscapes and providing other benefits to humans, in addition to food supply. Making visible and quantifying this added value is vital in order to help policy-makers to make better decisions about agriculture, decisions that take ecosystems and the food system into account as an aggregate.

This chapter provides an in-depth study of natural capital in the Maasai Steppe in Tanzania, where pastoralism plays an important role in preserving grassland landscapes and the ecosystem services they provide to humans. In particular, this chapter is a valuation of the internal natural capital present in the region, as well as a valuation of the impact of conversion from a pastoral landscape to agricultural land.

The analysis monetizes and compares the benefits derived by communities as natural capital stocks alter due to a major shift from a pastoralist cattle-rearing system to sedentary mixed crop-livestock farming. In addition to shedding light on the role of animal husbandry, land conversion and natural capital in the local context, it also presents a systematic approach to value the natural capital of regions.

A fully detailed explanation of the context, methods and results of this case study can be found in part III of the True Price Bottom-up Methodology report (True Price, 2016).

\subsection{Context: the challenges of land conversion in the Maasai Steppe}

Herds of Tanzanian Maasai pastoralists graze in the Maasai Steppe, one of the regions with the highest concentration of wildlife in the country. This area hosts some of the most visited national parks in Tanzania. Traditionally, both cattle and wildlife make use of the Maasai Steppe for feeding, as both wild animal populations and pastoralist herding systems are highly adapted to the extreme conditions of these arid grasslands.

In the past 40 years, however, agricultural land has been expanding in the region at a fast pace as traditionally nomadic local populations and immigrants from other regions of Tanzania settle down to establish farms in the region. This trend is viewed as unsustainable by many observers, including FAO (2009b). The expansion of farmland brings income to settlers, but it has a negative impact on both pastoralist populations and wildlife, as crops encroach upon migratory routes and the most fertile grazing areas are claimed by agriculture. Furthermore, as land in the Maasai Steppe is generally arid and not particularly suited for farming or keeping concentrated livestock, agriculture is characterized by low productivity and declining soil fertility. Degraded land that can no longer be used for farming or grazing is systematically abandoned. 


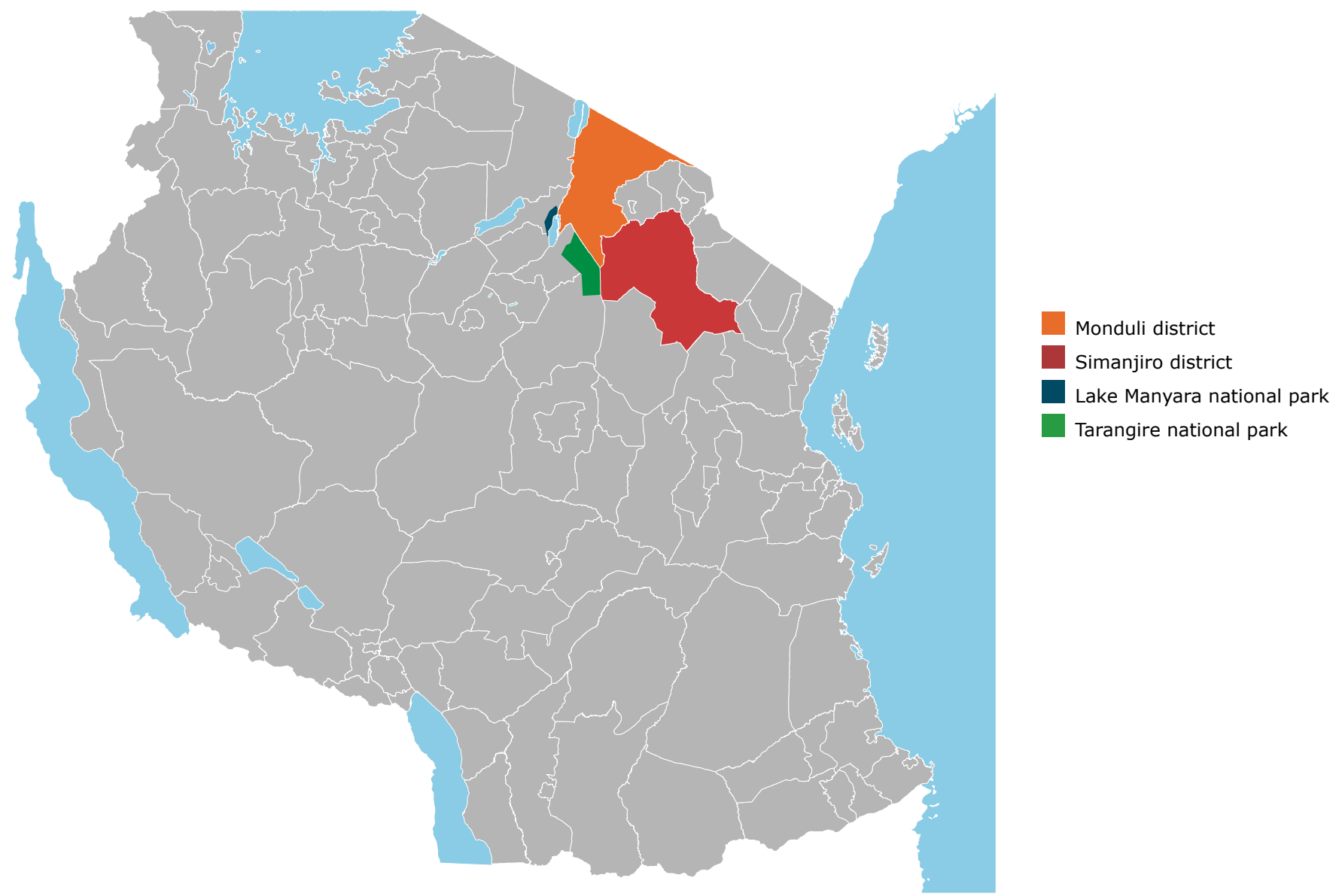

Figure 5.1 The regional scope

\subsection{Impact measurement and valuation approach}

\subsubsection{Decision context}

Policy-makers in the region face a critical trade-off regarding land conversion in the Maasai Steppe. Using land for agriculture is a more efficient way of extracting value from land to meet immediate food needs than traditional pastoral land use. At the same time the expansion of farmland is changing the region's landscape, which is causing the decline of other key ecosystem benefits for local populations. Hence, it is important to know the full value that land creates for local people. In addition, it is important that local and global policy-makers understand the regional externalities caused by land conversion. To inform decisions about agricultural development and landscape conservation, valuation of natural capital is an important tool, as it sheds light on the hidden benefits and costs of pastoral grassland ecosystems and conversion to sedentary agriculture. 


\subsubsection{Impact measurement}

The scope of the system is natural capital and the local economy in the Maasai Steppe for current and future years. The geographical scope of the Maasai steppe consists of two large and sparsely populated districts, namely Monduli and Simanjiro, and two adjacent national parks, namely Tarangire and Lake Manyara. The total area of this region is 2.9 million hectares, comprising $72 \%$ rangeland used by pastoralists and wild animals for grazing, 15\% mixed agricultural land, $11 \%$ nature reserves and $2 \%$ degraded land (full explanations of the modelling and valuation approach as well as data sources and general definitions are given, respectively, in chapters 3, 4, 5 and 2 of part III of the bottom-up methodology report (True Price, 2016)).

Ecosystem benefits are defined as the benefits enjoyed, consumed or used by beneficiaries from ecosystem services on a specific area of land. Because of the interconnectedness between ecosystem services, to avoid double counting only final ecosystem services are taken into account. ${ }^{26}$ Crops and agricultural products are also included. As a result, the following ecosystem services are quantified and valued in table 5.1 .

Table 5.1 Selection of ecosystem services quantified and valued

\begin{tabular}{llll} 
Crops and livestock & Traded products & Subsistence & Recreation \\
Beef and milk & Honey and beeswax & Wild foods & Tourism revenues \\
\hline Crops & Gum & Drinking water & \\
\hline Animal skins and hides & Medicinal plants & Non-timber forest products & \\
\hline
\end{tabular}

This study examines the natural capital trade-off between pastoral (semi-natural) rangelands and farmland. Using land as farmland is much more efficient at extracting value from ecosystem services, but also leads to land degradation and abandonment in the longer term (FAO, 2009b; Kshatriya et al., 2007). To examine this trade-off between non-sustainable agriculture and very low productivity pastoralism the internal value of natural capital in the Maasai Steppe is calculated under three alternative scenarios. ${ }^{27}$

High rate of conversion (= high speed) of rangeland to farmland ( $8 \%$ per year): leading to decline over time of some ecosystem services due to habitat encroachment and competition for the most fertile land.

Medium rate of conversion (=medium speed) to farmland (4\% per year): a middle-of-the-road scenario, where farmland expands at a slower pace, but still eventually reaches critical thresholds.

Low rate of conversion (= low speed) to farmland ( $2 \%$ per year): which keeps habitats and ecosystem processes intact within a safe threshold.

Scenarios are key to the analysis. Projections of what would happen to grasslands, national parks and cropland in each land-conversion scenario are used as input parameters together with land-cover change rates. See chapter 2 for a summary of the approach used for the valuation and True Price (2016) for an extended explanation of methodology (part III, chapters 2, 3 and 4.1-4.4) and data sources (part III, chapter 4.5). implicitly as they support the future supply of final ecosystem services.

${ }^{27}$ A discount rate of $3 \%$ was used to calculate the present value of future benefits. 


\subsection{Results}
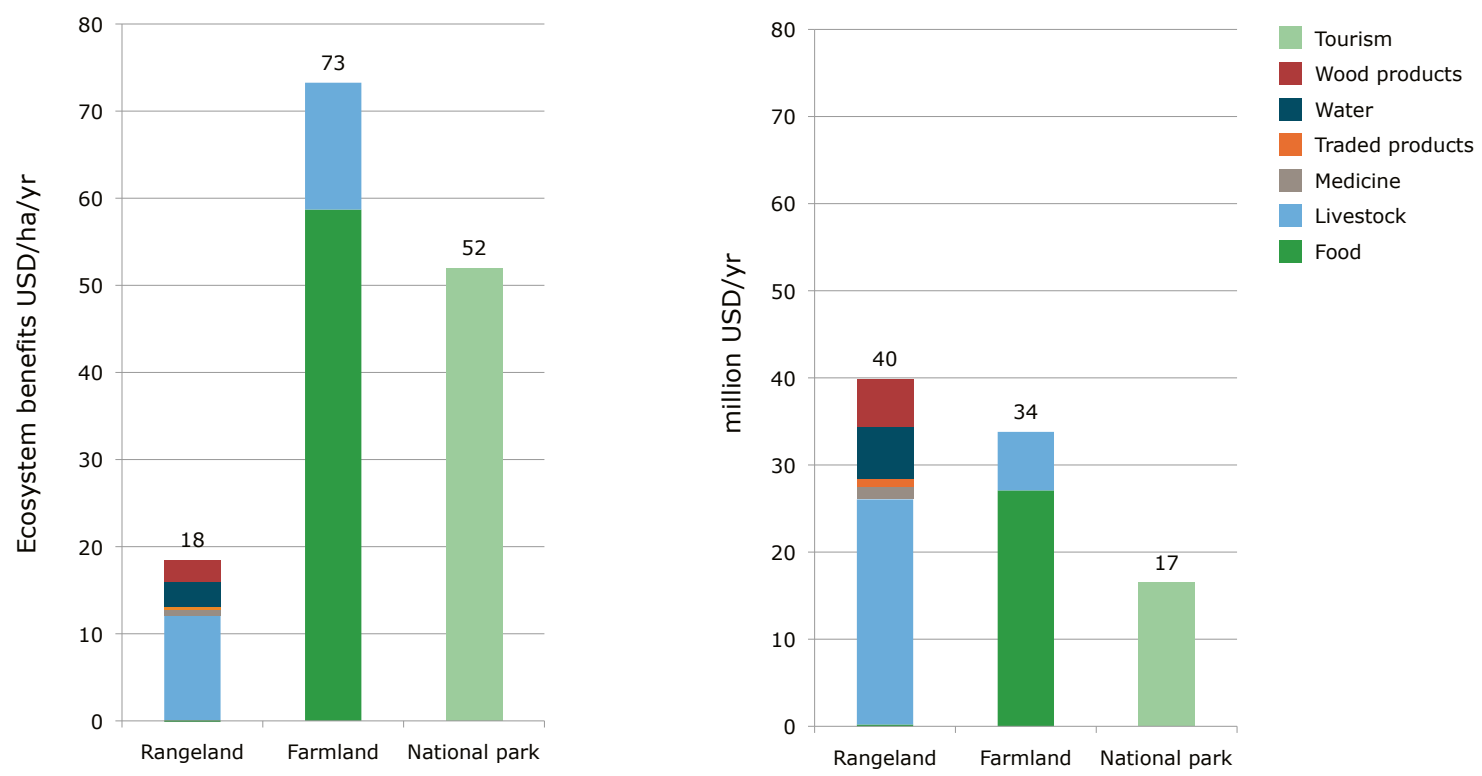

Figure 5.2 Annual ecosystem benefits

The two charts in figure 5.2 summarize the value of ecosystem benefits provided by land under different uses in one year in the Maasai Steppe. The results indicate that using land for agriculture is currently the most efficient way of generating value from natural capital, with value creation above US $\$ 73 /$ ha, as opposed to US $\$ 52 /$ ha for national parks and US $\$ 18 /$ ha for pastoralist rangelands. Rangelands have the lowest average value creation, but the most diverse set of ecosystem benefits. The value per hectare calculated for rangeland is within the same order of magnitude as studies in other dryland regions, namely 59 PPP2014/ha in Jordan and 3 PPP2014/ha in Botswana. Similar services were considered in both studies. The average value of 1244 US $\$ 2007 /$ ha provided by TEEB includes many regions with higher productivities. In addition, this average includes regulating services that are excluded, to prevent double counting (as they regulate future serve provisioning services), or are out of scope in this analysis. The value per hectare of mixed farming is based on a comprehensive review of mixed farming in the Maasai steppe (FAO, 2006). A comparison with national scale values provided by ILRI shows that the value of 275 PPP2014/ha is below the average of 1615 PPP2014/ha. However, the Maasai steppe is a relatively dry region and with very limited used of irrigation and other inputs compared to other agricultural regions in Tanzania. In interpreting these results it is important to consider the scope chosen for the assessment. What is included are the final ecosystem services that enjoyed in the region (for rangeland, mainly products used by households, for farmland, crops and livestock products, for national parks and recreation). Furthermore, no distinction was made regarding which groups are beneficiaries and to what extent their livelihood depends on the services in question. This perspective was beyond the scope of this analysis, but it is an important angle to take into account. In this case, however, beneficiaries from farmland and rangeland in the region, pastoralists and settled farmers, often belong to similar or even the same groups (agro-pastoralist communities) (Homewood et al., 2002).

Moving on from results per hectare to those on a regional basis, the ecosystem's estimated annual generation of value in the Maasai Steppe today is 90 million USD. Livestock keeping in rangelands and crop production are the two main sources of ecosystem value in the Maasai Steppe, accounting respectively for 31 and 27 million USD per year, or $28 \%$ and $30 \%$ of the total annual ecosystem benefits in the region. Farmland, which occupies only $15 \%$ of the area, generates $37 \%$ of total regional ecosystem benefits. 


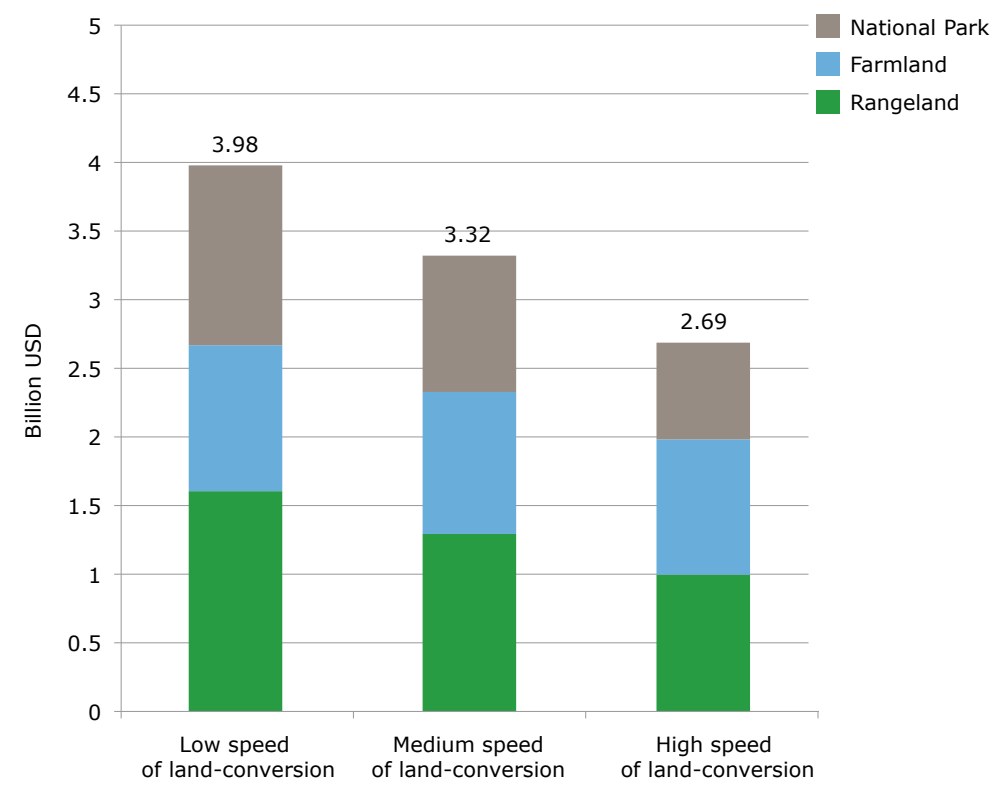

Figure 5.3 Internal natural capital value

Figure 5.3 shows the internal natural capital value of the Maasai Steppe, representing the discounted value of present and future benefits in alternative scenarios. It is estimated to be 2.7 billion USD for high-speed land conversion, 3.3 billion USD for medium-speed land conversion and 4 billion USD for low-speed land conversion. The value of farmland's ecosystem services is roughly the same in all scenarios, as the largest area of farmland in the high-conversion scenario is compensated by lower average yields due to the expansion into less fertile land and an increased rate of land degradation. On the other hand, the value of ecosystems in rangeland and national parks is lower when the growth of agriculture is faster, due to habitat fragmentation and competition for the most fertile regions.

The internal natural capital value depends both on the extent of ecosystem benefits as well as their sustainability over time. As the most fertile regions are converted first, the marginal agricultural benefits received by expanding farmland areas diminishes as expansion continues. However, continued expansion negatively affects ecosystem value creation of nature reserves and pastoralist rangeland, which both require critical land corridors to stay open for seasonal wildlife and cattle grazing.

These results show that although agricultural ecosystems are currently providing the largest share of ecosystem benefits in the region, slowing down the conversion rate will increase the value of natural capital. The conversion of rangeland to farmland reduces the overall average value of ecosystems by reducing the average value of farmland, rangeland and nature reserves and increasing the share of abandoned land. These reductions are much higher than the additional value created by more farmland.

\section{Sensitivity analysis}

Every natural capital valuation contains considerable uncertainty and therefore a sensitivity analysis has been provided. The analysis is performed to test the robustness of the results, which include a ranking of alternative scenarios in terms of natural capital and the overall value of the Maasai Steppe. It tests assumptions regarding the extent and speed of the preservation (or decline) of ecosystem services and the rate of land conversion, as well as the discount rate. A cross-simulation was carried out on 21 key parameters (from annual change in livestock and population density, to revenue of national parks, 
maximum extent of degraded land and discount rates of $2.5 \%, 3 \%$ and $5 \%$ ) to test whether different assumptions would change the results significantly, and the resulting 3,000+ possible combinations have been analysed. ${ }^{28}$

A cross-simulation was carried out on 21 key parameters (from annual change in livestock and population density, to revenue of national parks and maximum extent of degraded land) to test whether different assumptions would change the results significantly, and the resulting 3,000+ possible combinations have been analysed. The probability that the ranking of scenarios would not change under a different set of assumptions was found to be $74 \%$, meaning that one in four of the combinations tested have a different ranking among scenarios. However, the probability that the low conversion-rate scenario would have a natural capital value above the high conversion-rate scenario was found to be $89 \%$. The sets of assumptions that were found to most likely have high natural capital value in the high conversion scenario are those where the productivity trends of farmland (soil fertility), rangeland (average animal density) or national parks (revenues) would be considered the same in all scenarios. This means that agriculture could well expand without reducing natural capital, if it would do so without causing land degradation or posing threats to pastoralism and tourism.

Detailed results and a discussion of the key methodological strengths and limitations are found in chapters 5 and 7 of part III in the separate bottom-up methodology report (True Price, 2016). The sensitivity analysis can be found in chapter 6 of the same document.

\subsection{Carbon stocks}

The results described in the previous section refer to ecosystem benefits for local stakeholders, which contribute to the value of internal natural capital in the region. External ecosystem benefits provided by grasslands such as the Maasai Steppe include regulating ecosystem services such as water cycle effects outside this region, and carbon sequestration and storage, which benefit the global community. These benefits are usually higher in natural or semi-natural ecosystems, such as rangeland or national parks, than in agro-ecosystems, such as farms. The main reasons behind this are that with agriculture much carbon is removed every year in the form of crops and crop residues, and ploughing increases the respiration of soil micro-organisms and increases $\mathrm{CO}_{2}$ emissions. Their inclusion in the analysis is therefore not expected to reverse the conclusions. An analysis is performed in any case to compare differences in carbon stocks before and after land conversion to farmland in the three scenarios in question.

Values of carbon stocks per hectare are derived from a literature survey, and the difference in terms of land cover between now and after 20 years is translated into losses of carbon stocks. Values of carbon stocks used for rangeland, agricultural land and degraded land are assumed to be $87 \mathrm{tC} / \mathrm{ha}, 59 \mathrm{tC} / \mathrm{ha}$ and $31 \mathrm{tC} / \mathrm{ha}$, respectively (based on Petz et al. (2014b)).

The loss of carbon stocks is estimated for the high-conversion scenario, where the maximum area of farmable land is converted within 20 years, and the low conversion scenario, where not all farmable land is converted. The results are converted into $\mathrm{CO}_{2}$ equivalents and monetized using the social cost of carbon used throughout this report.

The effect of land conversion on external natural capital value, which includes the carbon stock, are much larger than the effect on the internal natural capital value, in the order of US\$15-24 billion rather than US \$2-5 billion. It is very important, however, to note that the stakeholders affected by carbon stock loss are the global population, whereas the stakeholders affected by the loss of internal natural capital are the local stakeholders managing the land. This analysis shows that the interests of local and global stakeholders do not conflict in this case but are aligned.

28 An assumption that was not tested is that present socio-economic trends (agricultural technology, population growth, access to water and trading of grassland products) will not change in the future. 


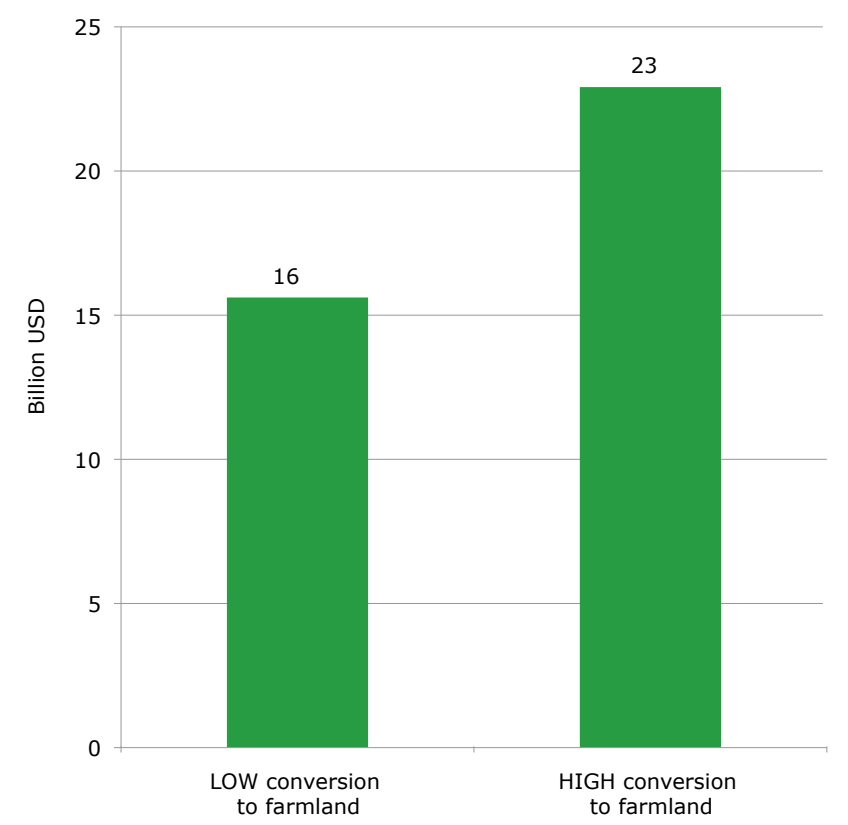

Figure 5.4 Value of carbon stock losses due to land-cover change in the Maasai Steppe, Tanzania (in billion USD)

\subsection{Interpretation}

The Maasai Steppe is facing a trade-off between increasing the short-term efficiency of land use by expanding agriculture, and preserving its rangelands, which are crucial for the functioning of not only pastoralist communities living on grassland-based livestock but also wildlife migrations and national parks. This research takes a geographically specific approach to quantify annual ecosystem benefits provided by different types of land use in this region. Possible future land conversion is developed in dynamics scenarios and compared in terms of how they determine the internal value of natural capital in the whole region.

Quantifying direct material benefits that people receive from land and ecosystems in this region shows that although the management of rangeland landscapes by pastoral communities has many side benefits, agricultural ecosystems are also important in the Maasai Steppe, and generate much higher ecosystem value per hectare than other land uses. However, when trends in growth and the decline of available ecosystem services are taken into account, it appears that slowing down the rate of conversion to farmland will increase the internal natural capital value of this region, which depends not only on the level of ecosystem benefits but also on its sustainability over time. Furthermore, because the potential reductions in carbon stocks related to land conversion have a high external cost, the global community also has an important stake in land-conversion dynamics in Tanzania. This provides a rationale for the global community to support efforts in the region towards ecosystem preservation that involve and benefit local stakeholders.

Pastoralism provides much more than meat and milk in the Maasai Steppe. By preserving the delicate rangeland landscape over time, it allows local populations to keep enjoying a broad range of benefits that depend on it, of which the most tangible ones - food, materials and water - were quantified here. Other ones, such as contributing to the cultural identity and the financial buffer of local populations, are also important, however. Beyond that, pastoralism also maintains the open space that wildlife in the region needs for seasonal migrations, contributing substantially to the value of national parks. Nonetheless, increasingly pastoral communities are resorting to crop farming, because of its short-term benefits. Many households are switching to agriculture or have started to combine arable farming with pastoralism. This trend is fragmenting the region's agricultural landscape, however, which can provide higher revenues in the short term but is likely to lead to high losses for the local population in the long run. Not only does 
agricultural land decrease the diversity of the benefits, but crucially it also generates a less sustainable stream of ecosystem services over time. This study quantified the potential losses, compared to a scenario where rangelands are conserved to a minimum extent, to be in the range of US\$2-3 billion for the whole region, taking into account only the final, tangible, ecosystem services mentioned above. This is because, contrary to farming, pastoralism in Tanzania can be seen as a landscape conservation system that benefits a range of different stakeholders in addition to the herd owners. The link between such benefits and pastoralism, however, is economically invisible, and there are no incentives for pastoral populations to keep fulfilling these functions instead of shifting to sedentary agriculture. This gap could be filled by the introduction of economic mechanisms meant to facilitate the internalization of externalities. One of these mechanisms is payment for ecosystem services, which makes it possible to conserve the ecosystem, in this case by pastoral land management, to be economically rewarded by a share of the revenues enjoyed by the current beneficiaries of ecosystem benefits ${ }^{29}$, in this case tourism operators.

More generally, livestock and agricultural systems do not exist in isolation, but instead have a complex relationship with the local ecosystems and local economy. The analysis presented in this chapter proposes an innovative method to measure the value that ecosystems (including agricultural ones) supply to human populations. Investigating the hidden benefits and costs of the shift from pastoralism to sedentary agriculture in Tanzanian grasslands has highlighted the fact that slowing down this conversion can create measurable natural capital value for local stakeholders.

\subsubsection{Relation with the bottom-up snapshot analysis}

These results can be used to add an economic layer to the analysis of pastoralism in Tanzania presented as part of the comparison of livestock snapshots in chapter 4.

Section 4.3.4 ('Land use and biodiversity') combined biodiversity impact factors (based on mean species abundance - MSA) with the land occupation results for the ten livestock snapshots to provide biodiversity-weighted land-use results. It highlighted the fact that the Tanzanian pastoralist system has a low impact on biodiversity ( $95 \%$ of pristine MSA) per unit of area where it is practiced, but at the same time also has very low land productivity in terms of $\mathrm{kg}$ protein produced per hectare.

This case study, however, takes a geographical perspective, looking at a region rather than a production perspective, which looks at animal protein, and a broader scope, by including more ecosystem services. It also focuses on only one of the considered snapshots (as the other Tanzanian cattle system, dairy mixed feeding, represents livestock farming in more humid parts of the country and is not comparable to the no-input-low-output farming practiced in the Maasai Steppe).

What the analysis of MSA impact per area captured in terms of biodiversity conservation, this case study quantifies, from the local perspective, in economic terms. This different angle of internal natural capital value in alternative scenarios shows the economic value of biodiversity conservation by pastoralism that the MSA indicator highlighted. For local conditions and effects on groups of beneficiaries of ecosystem services, it is especially this regional economic impact that is relevant. The impact on biodiversity per unit of protein becomes more important on a global scale.

29 For an overview of what are referred to as community-based payments for ecosystem services, see Dougill et al. (2012). These kinds of economic incentives are being applied in at least one instance in the Maasai Steppe region (Nelson, 2012; Sumba et al., 2005). 


\subsection{Key findings in-depth study Maasai Steppe}

The in-depth case study on pastoralism and landscape preservation adds an additional layer to the bottom-up valuation of the snapshot regarding the pastoralist beef system in Tanzania. An analysis of the internal value of natural capital takes a regional approach to provide a closer look at what other benefits pastoral rangeland ecosystems provide to human populations in the Maasai Steppe, beyond meat and milk production.

- The internal natural capital value of the Maasai steppe is estimated to be 2.7 billion USD for highspeed conversion from pastoral rangeland to agriculture, 3.3 billion USD for medium-speed land conversion and 4 billion USD for low-speed land conversion.

- Comparing three scenarios of different rates of land conversion from rangeland to agriculture, it appears that less pastoralism leads to less ecosystem value in the long run, although farming has the highest value in the short term. This result is explained by the negative effect of agricultural expansion on pastoralist access to grazing lands and on wildlife populations in national parks, together with the unsustainability of current farming patterns in the region.

- Although valuation always implies an intrinsic degree of uncertainty, a sensitivity analysis reveals the robustness of the main conclusion of the study. A scenario where conversion of land to agriculture slows down has a higher internal value of natural capital compared to a scenario where it expands rapidly with an $89 \%$ confidence within the considered uncertainty ranges.

- Additionally, carbon emissions due to land-use change are also an important externality of conversion to agriculture, estimated to range from 15 billion USD in the low speed scenario to 24 billion USD in the high speed scenario. Expanding the analysis to carbon stocks confirms that the interests of global communities are aligned with the local community, as global communities will also benefit from a slower rate of conversion.

- Animal husbandry provides the largest share of benefits from ecosystems for the local population in the Maasai Steppe. Pastoralism and sedentary farming both contribute equally to this value creation, mainly through food production, although skins and hides are also marketable products in this region.

- Two other large components of natural capital value in the region today are crops and tourism. A literature study reveals that these two activities are in competition, as expansion of farmland threatens wildlife migration corridors, negatively affecting animal populations, which in turn are the basis for touristic values.

- Other forms of direct value creation from ecosystems and biodiversity are raw materials, wild food and medicinal herbs, drinking water and forest products such as honey and beeswax. These goods have a lower market value but can still constitute an important means of subsistence for the local population. 


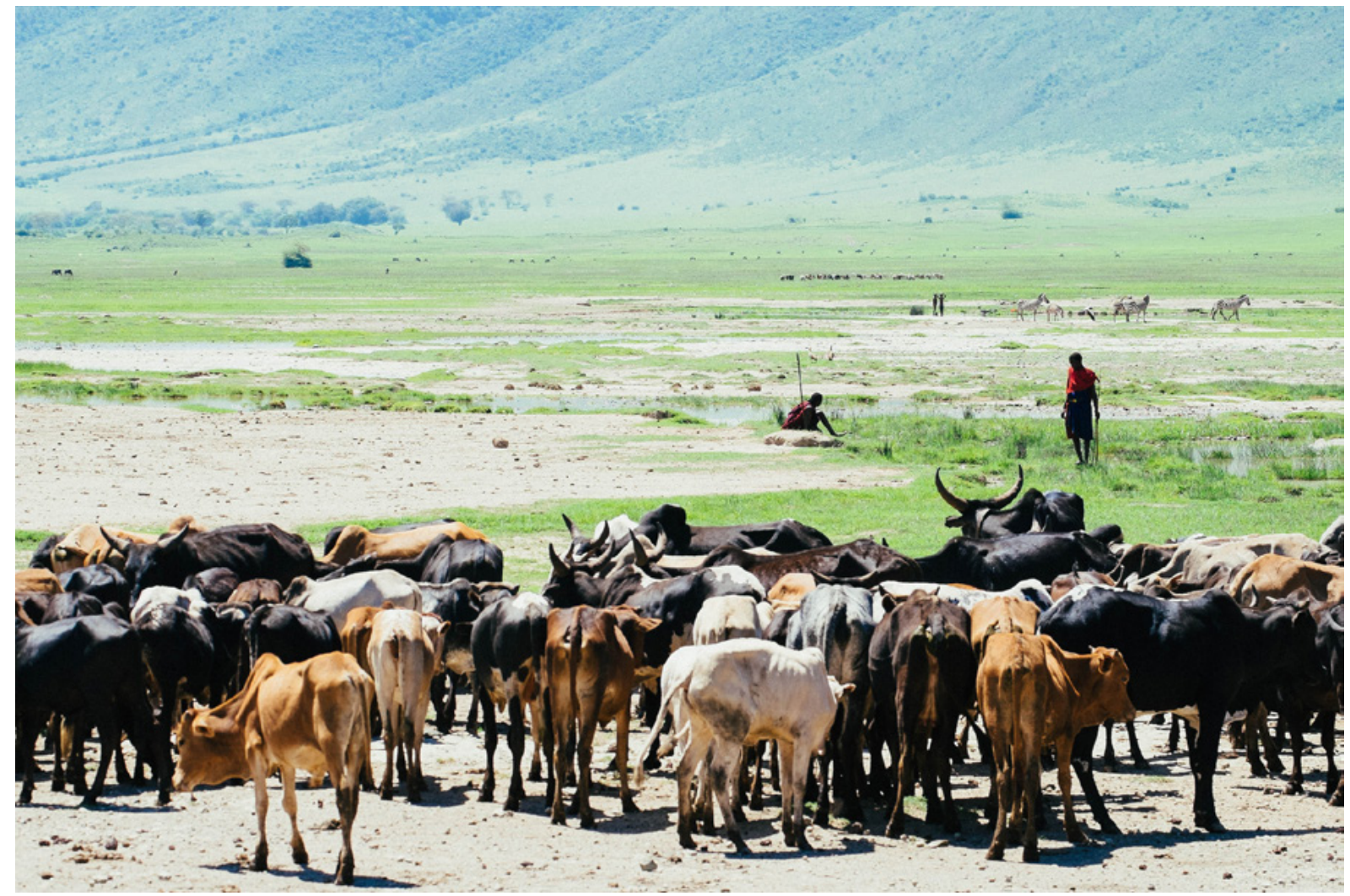

Picture 5.1 Maasai herds

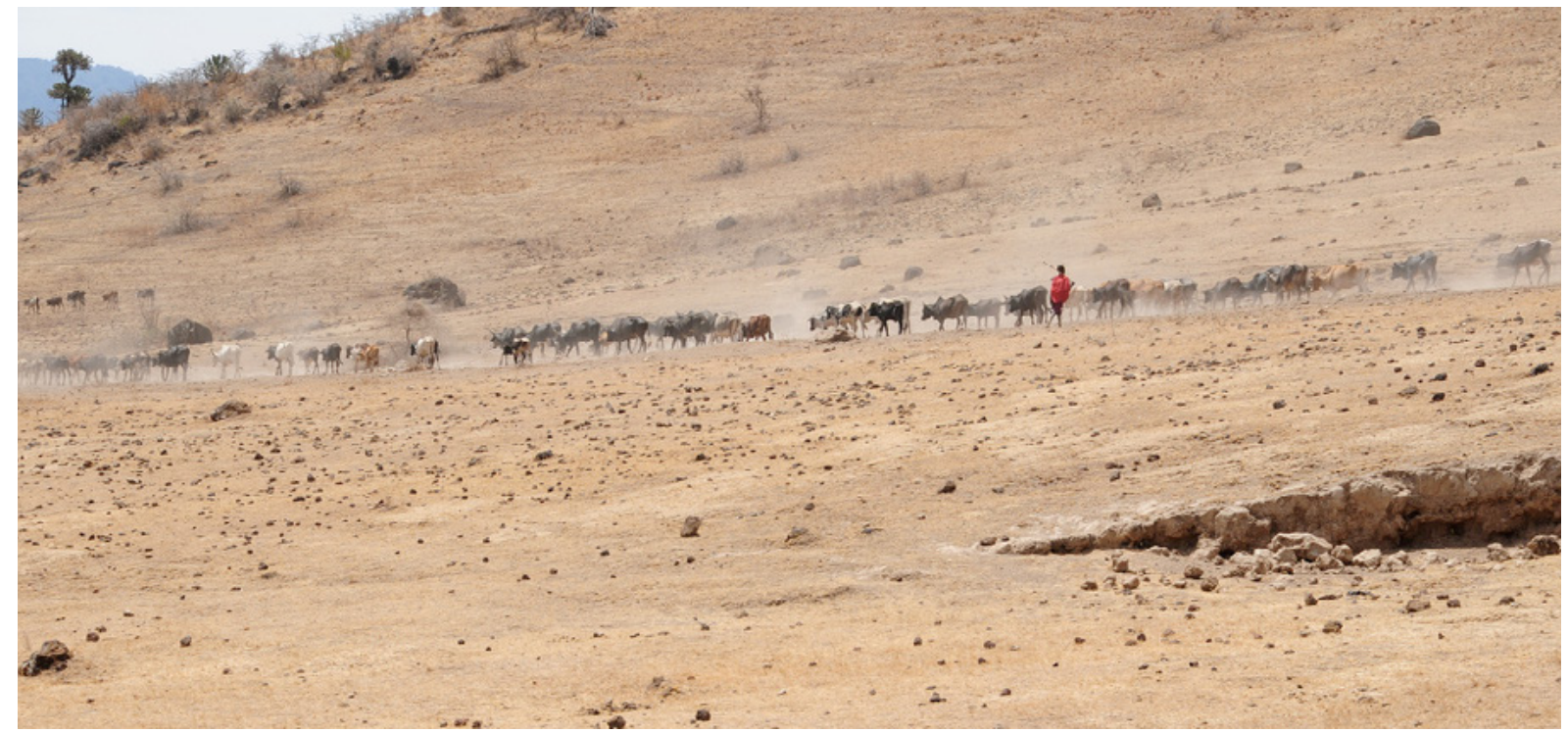

Picture 5.2 Maasai herdsman 


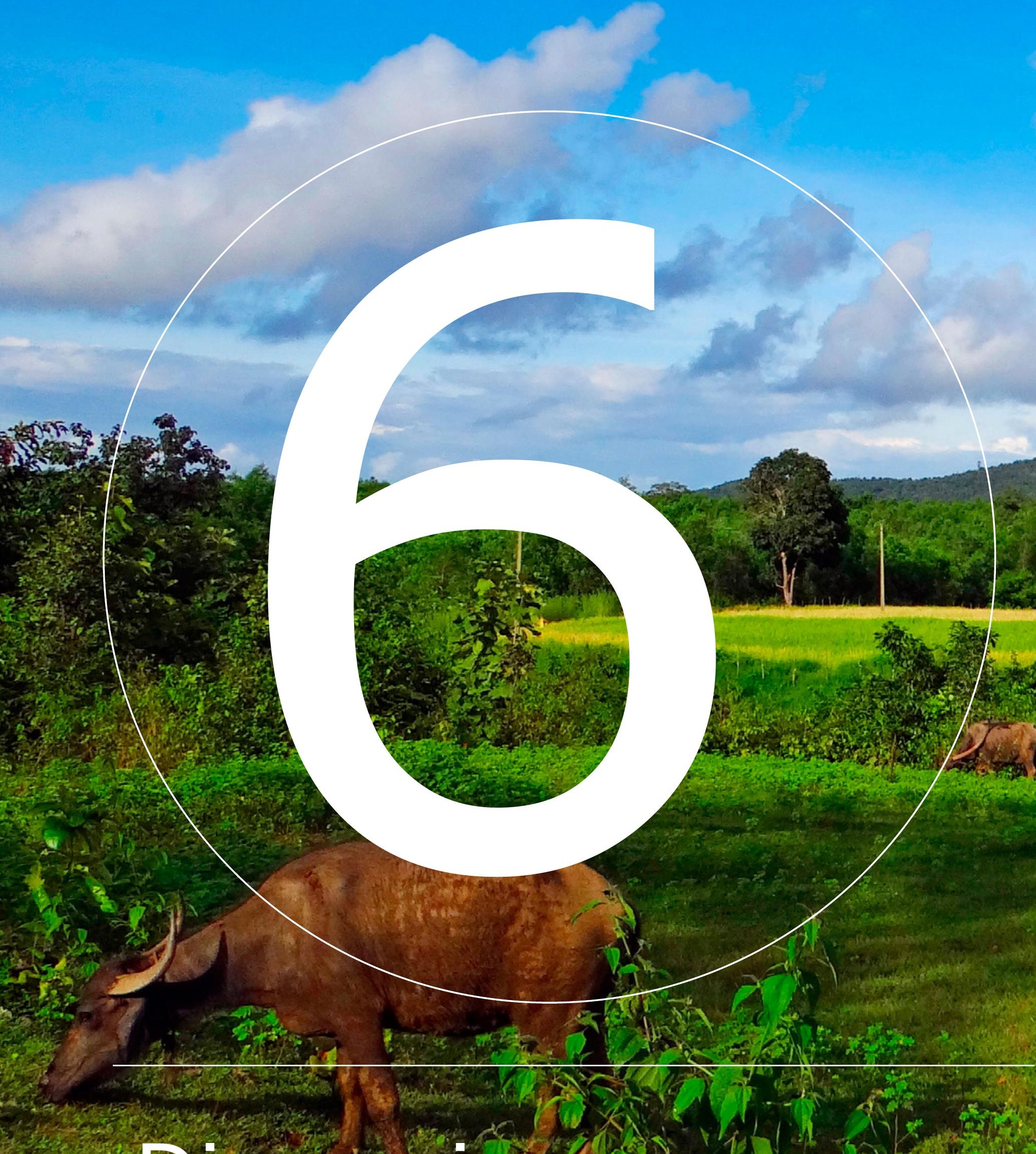


6.1

Findings in perspective

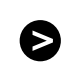

\section{2}

Scope of the livestock study

\section{3}

Individual dietary preferences

$\nabla$

6.4

How to meet future demand

$\nabla$

6.5

Supplying animal proteins without losing natural capital

$\nabla$

6.5.1

Scenarios show huge production

increase in Africa

\section{5 .2}

People are moving

$\nabla$ to urban areas

\section{5 .3}

Response per species and snapshots $\nabla$

$\rightarrow$

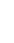




\section{Discussion}

\subsection{Findings in perspective}

In average terms, the natural capital costs per $\mathrm{kg}$ of animal protein were found to be the lowest for chicken and the highest for beef. Milk was found to be in an intermediate position for all snapshots considered, and in the case of the top-down approach for some specific countries there was an overlap of intensities for milk and poultry. Land-use change and greenhouse gas emissions were found to be the dominant factors in determining the natural capital costs per $\mathrm{kg}$ of protein for the three commodities: milk, poultry meat and beef.

Differences in greenhouse gases and land use between commodities can largely be explained by three factors:

a Enteric fermentation is a large contributor to GHG emissions in cattle systems, but not in poultry systems;

b The large difference in reproduction efficiency: average cow fertility is 0.75 to 0.85 calve per year; the reproduction cycles in chicken are far shorter and number of offspring per hen is far higher. This is also the case in the backyard systems. The low reproduction efficiency is especially important in pure beef systems (Opio et al., 2013);

c Feed quality; digestibility of animal rations is higher for chicken than for cattle, especially in the cattle systems in developing countries where crop residues are an important fraction of the ration. High feed quality improves feed-conversion rates, which reduces feed requirements and hence the greenhouse gases and the land use per unit of protein produced.

These findings are in line with those of de Vries and de Boer (2010). The study also showed that there is a large variation within species, with beef having the highest intensity, followed by milk and poultry meat, which overlap in some instances in terms of GHG emissions and also land use. It should be noted that as Gill et al. (2010) demonstrate, the relative intensity between species could also be affected when considering the human edibility of the feed.

In addition, if other issues such as animal health or additional benefits provided by livestock could be quantified and valued, a more integral assessment of the relationship of livestock systems and natural capital could be made. Integrating these issues could also alter the order of species with regard to total natural capital costs and their benefits. For example, as described in section 3.3 animal health has a direct impact on human health, and the risks of zoonoses in poultry production can differ from the risks of zoonoses in cattle production.

We suggest that an integral assessment of livestock production systems and their linkage to natural capital, especially if species are compared, should include animal and public health, human edibility of feed and the benefits that different livestock species provide. For the moment, those inclusions are not feasible as indicators because the data and models to evaluate them are lacking.

\subsection{Scope of the livestock study}

The present study about livestock production systems is restricted in two ways. First, important sectors such pork production, egg production and also goats and sheep are not taken into account. The second restriction is that even within the beef, milk and chicken meat supply chains we had to make choices in the bottom-up approach among the snapshots. The main reasons for limiting the scope of the study were data and resource availability. 
The beef, milk and chicken meat sectors were proposed because these sectors are the main suppliers of animal proteins in almost all countries in the world and because several scenario studies expect the production of beef, milk and chicken meat to grow in the near future. A complete overview of the positive and negative impacts of livestock production systems would have to take into account the production of eggs, pork and goat/ sheep meat and milk.

For an integrated assessment of the livestock study the total supply chain of feed production till consumption of the produce should be taken into account (from 'cradle to grave'). See TEEBAgriFood framework (Interim report 2015, figure 2.2) as an example ${ }^{30}$.

Within this study the focus was on the 'farm level' and the feed production outside the 'own' farm was taken into account as well. From life-cycle analysis (LCA) studies we know that most of the impact of livestock production is related to feed production and on-farm activities (see Thoma et al., 2013). However, the supply chains differ a lot among the snapshots which have been taken into account (own consumption, transport, processing and consumption). These differences do have an impact on livelihoods and ecosystems. The second reason to limit the assessment to the farm gate is the lack of information and data. For example for GHG emission GLEAM has coefficients for the total supply chain (including processing and consumption), but this data is not available for other externalities. For the bottom-up approach data on home consumption, informal markets and processing, for example, is lacking, especially for pastoralist and smallholder systems. But LCA studies are often limited to the farm gate for Western markets with a lot of information as well.

\subsection{Individual dietary preferences}

In the previous chapters it has been assumed that production will largely follow the consumption needs of local people. If humans would adapt their diets and eat less meat or drink milk instead of eating beef the total natural capital costs could be far lower in the future. The reality, however, is that humans are unlikely to change their diets easily (Higgs, 2015). Consumers do not think in terms of kg of animal proteins but in products such as beef, milk, cheese, pork or chicken meat. Aspects such as health, low prices, easiness to prepare, societal norms, habits and conscience are leading drivers for consumers when buying food in industrialized countries. So even if chicken meat has far fewer natural capital costs than beef it will be hard to substitute beef for chicken meat in the diet. Also a reduction of animal protein consumption would have a big impact on total natural capital costs because the expected increase of production in the future will be less. The same is true when food waste is reduced. The impact of reducing the amount of animal protein in the diet of people in industrialized regions should not be overestimated. An assessment, based on FAO (2006), assuming that animal protein consumption will decrease by $50 \%$ in industrialized regions (Europe, North America and Oceania) shows that an increase in the consumption of animal protein is likely at a global scale. Figure 6.1 is a modification of the graph by FAO (2006).

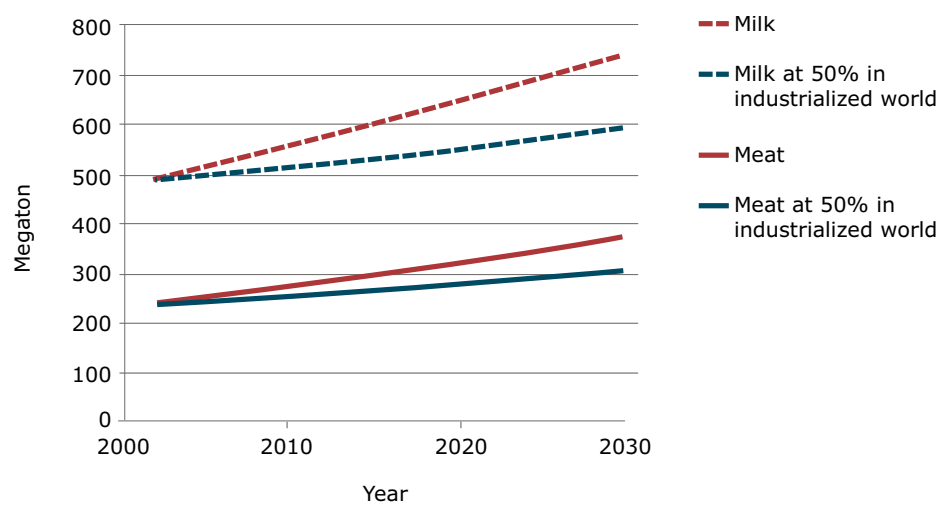

Figure 6.1 Global consumption of meat and milk until 2030, based on calculations by FAO (2006) and providing consumption in industrialized countries falls by $50 \%$ over that period. Graph based on FAO (2006)

30 see http://img.teebweb.org/wp-content/uploads/2016/01/TEEBAgFood_Interim_Report_2015_web.pdf 
So even if drastic changes occur in consumption patterns in industrialized countries, global meat and milk consumption will increase, because of the strong increase in developing countries.

\subsection{How to meet future demand}

This increase in consumption will require an increase in livestock production. The assessment of the livestock production systems in chapters 3 and 4 were done in a static way, looking at snapshots in time and the annual environmental impacts of producing animal protein. The increased production will go hand in hand with changes in livestock production systems and shifts from one livestock production system to another. Some of the expected developments are:

a Livestock production systems become more efficient; more output (milk, beef) is produced with less input (feed) with the same throughput (cow);

b Intensity of livestock production systems (there can be a trade-off between GHG emissions in low-intensity systems and water quality effects in high intensity systems); and

c Animal proteins can be produced by different species and end up in different products (eggs, milk, beef, pork, chicken meat).

From the top-down and bottom-up assessment we know that positive and negative externalities strongly depend on:

- livestock species (per unit of protein negative externalities are increasing in the order of chicken meat, milk and beef);

- intensity of livestock production systems (more intensive usually means fewer negative externalities); and

- increased efficiency or productivity (in a livestock production system, negative externalities decrease if more output is produced with the same input or the same output is produced with less input).

In box 6.1, Gerber et al. (2011) describe the productivity development and impact on greenhouse gases for different dairy production systems. From this research it can be concluded that in the dairy sector the production of milk can increase without increasing greenhouse gases. This is especially an opportunity for smallholders with a present annual production per cow of less than 500-1,000 kg FPCM. This is less true for dairy systems with high production levels of 4,000 or more kg FPCM. Intensification can also be expected to lead to lower land requirements, but higher nutrient surpluses. Whether it would correspond to a net benefit from a natural capital point of view depends on local conditions, such as the risk of eutrophication of local water bodies and the degree to which land in the original smallholder systems provided co-benefits to the local population, i.e. ecosystem services, in addition to meat and milk.

\subsection{Supplying animal proteins without losing natural capital}

\subsubsection{Scenarios show a huge production increase in Africa}

Scenario studies have been used to get a sense of how the production and consumption of animal protein might evolve. ${ }^{31}$ Scenario analyses have the advantage that the long-term fundamentals of demand (consumption) and supply (production) are regarded jointly, within consistent storylines and quantification. We summarize the main results of shared socio-economic pathways (SSP 1: low challenges: SSP 2: medium challenges: SSP3: high challenges). As key resources for the scenario analysis we will use the African Livestock Futures report (Herrero et al., 2014) and the results of the ANIMALCHANGE project, including a report on storylines and driver quantification (Soussana, 2012) and the preliminary quantification of scenarios (Havlik et al., 2013). This choice also implies that only results for Europe, Latin America and sub-Saharan Africa are available.

In our analysis we will make use of the Shared Socioeconomic Pathways. This framework was developed for the IPCC AR5 report. It consists of a set of storylines for global development pathways up to 2050 with an accompanying set of assumptions on population/income growth and headline rates of technological change. These assumptions are used to assess expected growth and composition of protein demand and the composition of the supply response and the related change in natural resource use. The analysis makes use of published modelling results which indicate how the technological change in the livestock sector is distributed in terms of the progress in efficiency across various systems. 
The year 2050 has been widely referred to as a benchmark for exploring a range of systematic transformations for food systems around the globe. The livestock sector is essential to solutions for making agricultural production systems more responsive to nutritional and environmental concerns (IAASTD, 2009; UK Foresight, 2011). Policy-making on food security, climate-change mitigation and adaptation requires a time-frame with compounded effects over time. Given these pathways we analysed what role the different snapshots can or will play in the future and what impact this can have on the positive and negative externalities.

Box 6.2 describes the main characteristics of the scenario study. Table 6.1 summarizes the results regarding the supply of animal products in terms of calories per region. The calculations show that the production growth of animal calories in the coming decades is set to rise in Latin America and even more in Africa and the Middle East. The supply of animal calories is expected to grow by $5 \%$ to $10 \%$ in Europe, $60 \%$ to $140 \%$ in Latin America and $230 \%$ to $300 \%$ in Africa and the Middle East. This increased supply is connected to the expansion of cropland and grassland (see table 6.2). In total 600 million ha will change from forest and natural land to cropland and grassland. The increase is large in Africa and the Middle East (about 50\%); substantial in Latin America (+30\%) and marginal in Europe $(<5 \%)$. The calculated impact on GHG per scenario differs substantially. In scenario SSP1, GHG related to animal production go down from 7,000 million tonnes $\mathrm{CO}_{2}$ equ in 2000 to 6,000 million tonnes in 2050, while SSP2 has an increase of GHG to a level of 9,000 million tonnes in 2050. The results of the scenario study also state that for monogastric production (mainly pigs and poultry) the growth will be in industrialized systems. For ruminants the mixed feed system will survive where, especially in Africa and the Middle East, the majority $(67 \%)$ of the production will still come from smallholders in 2050 (Deliverable 2.2 Animal change). Although the ANIMALCHANGE project does not describe the impacts of the different scenarios on the ecosystem, it is obvious that huge impacts on ecosystems can be expected in regions such as Latin American, Africa and the Middle East where animal production will grow. The final impact on the ecosystem will strongly depend on the type of scenario. Negative impacts on ecosystems can be minimized if total demand is lower, efficiency is increased and losses and waste are decreased.

Table 6.1 Results: Supply of animal calories by region (percentage increase 2000 to 2050)

\begin{tabular}{llll} 
Region & Scenario $^{1}$ & & \\
& Sustainability SSP1 & Middle of the road SSP2 & Fragmentation SSP3 \\
\hline Europe & 5 & 10 & 5 \\
\hline Latin America & 60 & 140 & 130 \\
\hline Africa \& the Middle East & 280 & 300 & 230 \\
\hline
\end{tabular}

1 for scenario description see box 6.2

Table 6.2 Results: expansion of grassland and cropland (in percentage of increase per region as part of total increase in the world in SSP 2 'middle of the road')

\begin{tabular}{lll} 
Region & Cropland & Grassland \\
\hline Europe & 4 & 1 \\
\hline Latin America & 30 & 27 \\
\hline Africa \& the Middle East & 55 & 43 \\
\hline World & 100 & 100 \\
\hline
\end{tabular}




\subsubsection{People are moving to urban areas}

All over the world, people are expected to move to urban areas, and the number of people living in rural areas is therefore expected to decline. This trend is especially evident in Africa and Asia. The demand for animal protein is therefore likely to increase in urban areas.

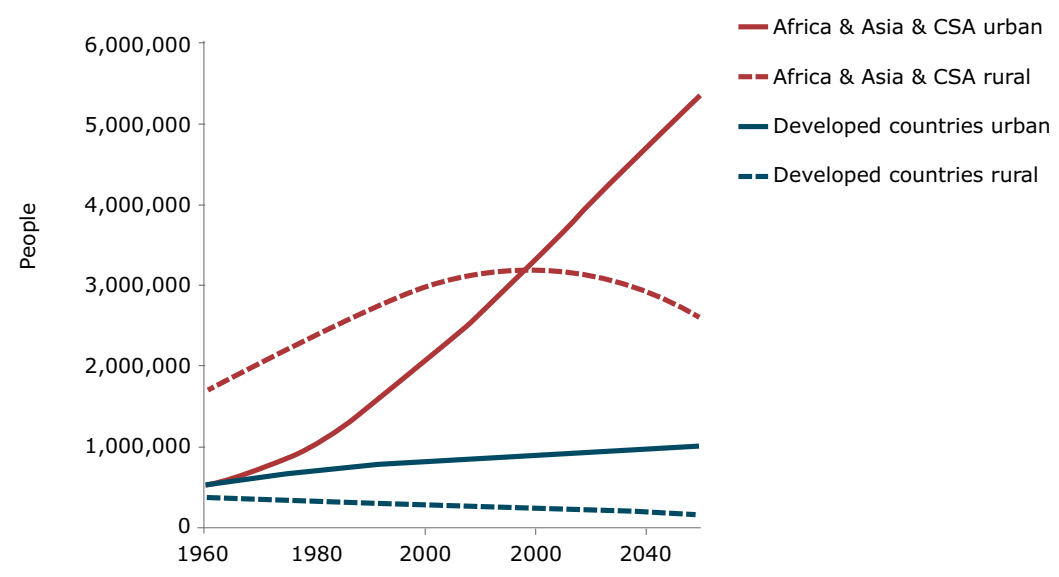

Figure 6.2 Number of people living in rural and urban areas in Africa, Asia and Central and South America and in developed countries (Europe, North America and Oceania). Source: UN statistics (www.un.org)

\subsubsection{Response per species and snapshots}

\section{Poultry}

Regarding the poultry systems, it is likely the number of animals kept in backyard systems will stay constant or slowly decline, in line with the size of the rural population. In rural areas the backyard system will continue to supply local needs. To feed the future influx of people into urban areas, commercial industrialized production systems will expand strongly, together with the feed supply industry, veterinarian services, slaughterhouses and the meat-processing industry (see ILRI, 2015). The industrialized production system will not replace the backyard system, but it will produce what is needed for the increased demand. On a global but also on a country scale, a shift from backyard systems to industrialized systems is expected (in terms of \% of total production). Indeed, this process has started already in all parts of the world. The mix of a semi-intensive and an industrialized system will strongly depend on the organization of the supply chain. If the world's major poultry companies get involved, industrialized production systems are likely to emerge because they are more efficient. Regarding the natural capital costs, the differences between the two systems are essentially negligible. There are two important aspects that need to be addressed. The first one is the gamut of risks associated with industrialized systems (air pollution, soil pollution, animal diseases and the use of antibiotics) for local people. These have to be mitigated by good management of manure and the animals, for example. The second one is the fact that industrialized systems rely heavily on feed produced elsewhere in the world. This feed production should be sustainable so that natural capital costs are kept to a minimum. Nutrient recycling, i.e. proper management and use of manure is key in this regard, as it will help to prevent the depletion of soil in one region and accumulation and pollution in another. 


\section{Dairy systems}

Regarding dairy systems, a study of Gerber et al. (2011) is used to gain insight into the development of the different dairy production systems (see box 6.1). It explains that the dairy snapshots described in chapter 4 (situation 2010) can differ from the expected dairy production system in 2050. However, smallholder dairy farming is expected to remain an important production system in Tanzania, India and Indonesia. With improved resource use efficiency, these systems have a high potential to increase milk (and meat) production and substantially reduce emissions per unit of product (Gerber et al., 2013, 2011). This is not only a theoretical analysis. The National Dairy Plan of India is based on the same analysis and is focusing on breeding and nutrition, in combination with chain development (National Dairy Development Board, 2012). As Gerber et al. (2011) show, GHG emissions per kg of protein can be decreased considerably if farms are optimized and the production per cow increases from $500 \mathrm{~kg}$ per cow to $3,000 \mathrm{~kg}$ per cow. In the Netherlands, as in most of the industrialized world, the present intensive and highly specialized dairy production system will remain important. Increasing the scale in all stages of the supply chain is likely to continue. For the natural capital costs, the potential reduction of the gains in efficiency are less than what would happen if smallholder farms were optimized. Although natural capital costs per $\mathrm{kg}$ of protein will not decrease much, the scale of farms and companies in the supply chain will continue to increase because of economies of scale.

\section{Beef systems}

The growth of the dairy sector will also lead to more beef production. Beef production from dairy systems can be substantial, even in highly specialized dairy systems in developed countries. The offspring and life-weight-production for slaughter in specialized beef and dairy systems in Brazil, based on the animals' weights, fertility, replacement rates and mortality rates during their lifetime are in the same range: $200,000 \mathrm{~kg}$ to $300,000 \mathrm{~kg}$ life weight for a herd of 2,400 animals. It shows that meat production from dairy systems is important and that the development and growth of pure beef systems will depend on the development of the global dairy sector.

If the dairy sector becomes too specialized and shifts more to milk-type animals and to the culling of young calves before fattening, meat production in the dairy sector will decrease, leaving more room for a pure beef sector. Despite the importance of beef production from the dairy sector, Brazilian beef production from pure beef systems is expected to increase. Santana et al. (2010) calculate an increase of 43 million heads, from 205 million heads of cattle in 2006 to 249 million cattle stock in 2030. The production of oil crops (i.e. soybean) is expected to increase in addition to pasture as well. The present extensive grazing systems in Brazil are expected to be replaced by the more intensive grass-based systems combined with feedlots at the end of the fattening stage. The impact on the natural capital of this technology path is modest but the amount of land required per unit of protein produced will decrease more significantly (see sections 4.3.1, 4.3.2, 4.3.3). The pastoralist systems in Africa and Asia are expected to decrease because the total area of these systems will decrease. Transhumance systems will lessen in number, land will be used for mixed cropping systems, due to population increases. On the other hand, from a landscape point of view the pastoralist systems should be safeguarded (see chapter 5 ), as their role in landscape maintenance is much more important than animal protein production. 


\section{BOX 6.1 Developments within dairy production systems}

Gerber et al. (2011) shows the influence of milk production per cow (in fat and protein corrected milk (FPCM) per year) on greenhouse gas emissions (see figure 6.3). Although the graph gives the impression of a continuous relationship, in fact three major livestock production systems can be distinguished: subsistence farming with limited access to markets and local selling of products (output of $500 \mathrm{~kg}$ FPCM per cow per year or less); small-scale farming better linked to markets (output between 500 and 3,000 kg FPCM per cow per year; and specialized, large-scale dairy farms producing more than 3,000 kg FPCM per cow per year. The option for development and mitigating the external impacts strongly differ among these types of livestock production systems. Subsistence farmers have (almost) no access to markets and options to mitigate external impacts are non-existent. For smallholder systems, output increases per cow are possible by optimizing the multifunctional farm system, which is shown in the approach mentioned in the National Dairy Plan of India and described by (Garg et al., 2013). This can be achieved by applying existing technology via capacity building and technology transfer, developing a good infrastructure and institutions, and providing good market access. The snapshots of India, Tanzania and Indonesia are good representatives of this important group of producers. For the specialized systems, increasing the output per cow is achieved by further optimizing animal health and nutrition. However, increases in production at highly productive farms is limited. Increasing the output at specialized farms can be achieved by new technology and system innovations (feed additives and genomics).

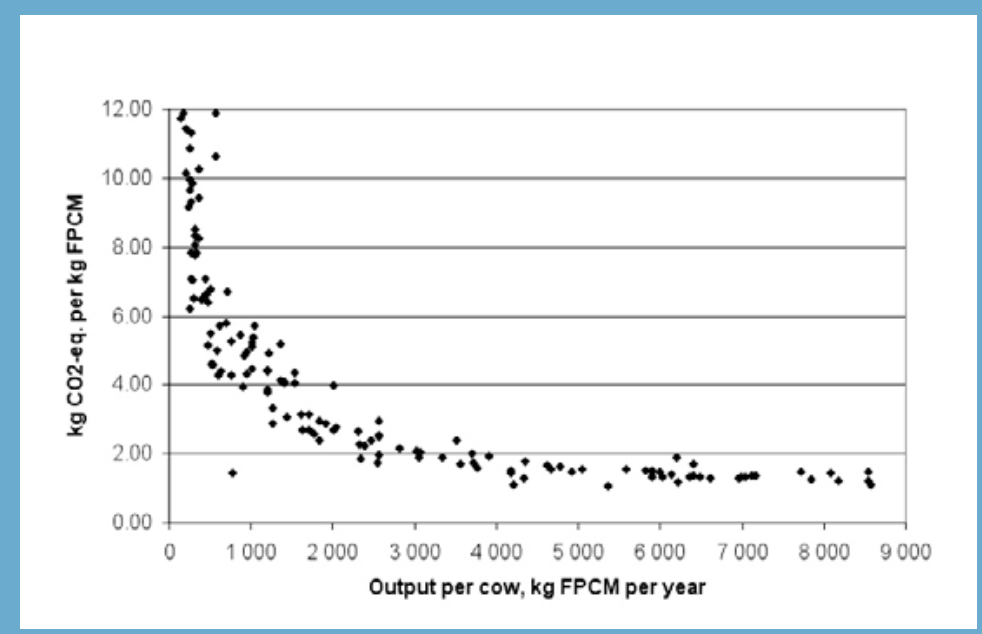

Figure 6.3 Relation between output per cow and greenhouse gas emissions (source Gerber et al., 2011)

Gerber et al. (2011; 2013) show that livestock production systems can increase productivity, thereby decreasing the natural capital costs per kg of protein (GHG and land use).

The IPCC SSPS define the scenarios partly in terms of technology change. Gerber et al. $(2011 ; 2013)$ show that the application of existing technology already can have a large impact and that the importance of new technology depends on the type of dairy production system. 


\section{BOX 6.2 Review of scenario studies focused on animal products}

See http://www.animalchange.eu/Content/deliverables.html

\section{Important drivers for consumption}

Demand drivers in the livestock sector are population growth, income growth, urbanization and preference shifts.

\section{Consumption growth}

A leading FAO projection driven by expert judgment is that global livestock consumption will be $76 \%$ higher in 2050 compared to a base in 2005 (Alexandratos and Bruinsma, 2012). Recent modelling efforts suggest that this may be an upper bound estimate. Indeed, analysts' opinions about the projected pattern of livestock demand differ widely (Valin et al., 2014). The demand projections are substantially influenced by assumptions on demographic change and economic growth. The FAO projection suggests that the consumption of livestock products per capita will increase by $27 \%$ (i.e. population expansion pushes consumption up by $49 \%$ ), but modelling projections range from $12 \%$ to $41 \%$, leaving aside some extreme estimates that project an increase in per capita consumption of more than double.

\section{Important drivers for supply}

The supply response needed is substantial in absolute terms. Alexandratos and Bruinsma (2012, p. 17) project that cereals production must increase by 940 million tonnes to reach the 3 billion tonnes projected for 2050; meat by 196 million tonnes to reach 455 million tonnes by 2050; and oil crops by 133 million tonnes to reach 282 million tonnes by 2050 . The supply response is, however, highly uncertain. The main drivers on the supply side are the availability of roughage, feed and feed concentrates at affordable prices, technological progress in crop yields and animal production (see Bouwman et al., 2005; Lesschen et al., 2011; Oenema and Tamminga, 2005; Soussana, 2012; Westhoek et al., 2011), and international trade in animal products to redress the demand and supply imbalances.

\section{Scenario description and main assumptions per scenario}

SSP1 is the sustainable world with strong development goals that include reducing fossil fuel dependency and rapid technological changes directed at environmentally friendly processes, including yield-enhancing technologies. Population growth is modest.

SSP2 is the continuation of current trends with some effort to reach development goals and reduce resource and energy intensity. On the demand side, investments in education are not sufficient to slow down rapid population growth. SSP2 only has intermediate success in addressing vulnerability to climate change.

SSP3 is a fragmented world characterized by strong population growth and important regional differences in wealth, with pockets of wealth and regions of high poverty. Unmitigated emissions are high, low adaptive capacity and large number of people vulnerable to climate change. Impact on ecosystems are severe.

\begin{tabular}{|c|c|c|c|}
\hline & 'Sustainability' SSP1 & 'Middle of the road' SSP2 & 'Fragmentation' SSP3 \\
\hline Global population in 2050 & 8.5 billion & 9.2 billion & 9.9 billion \\
\hline $\begin{array}{l}\text { Average per capita income } \\
\text { in } 2050\end{array}$ & US $\$ 20,000$ & +/- US $\$ 15,000$ & $<$ US $\$ 10,000$ \\
\hline $\begin{array}{l}\text { Preference for animal protein } \\
2005-2050\end{array}$ & $\begin{array}{l}\text { Reduced income elasticity of } \\
\text { meat consumption }\end{array}$ & Status quo & Status quo \\
\hline $\begin{array}{l}\text { Technological change } 2010- \\
2050 \text { (crops) }\end{array}$ & $\begin{array}{l}\text { Strong push for productivity } \\
\& \text { resource efficiency }\end{array}$ & $\begin{array}{l}\text { Modest push for productivity } \\
\text { \& resource efficiency }\end{array}$ & $\begin{array}{l}\text { Limited push for productivity } \\
\text { \& resource efficiency }\end{array}$ \\
\hline
\end{tabular}




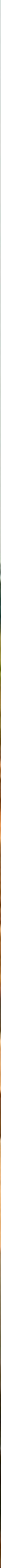

\section{Conclusions}

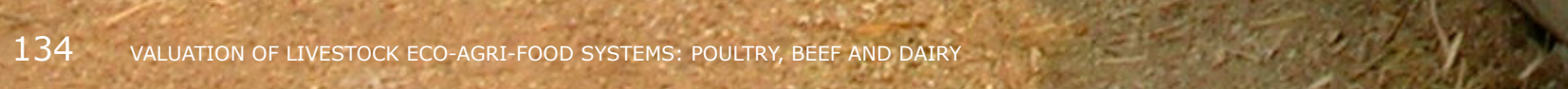




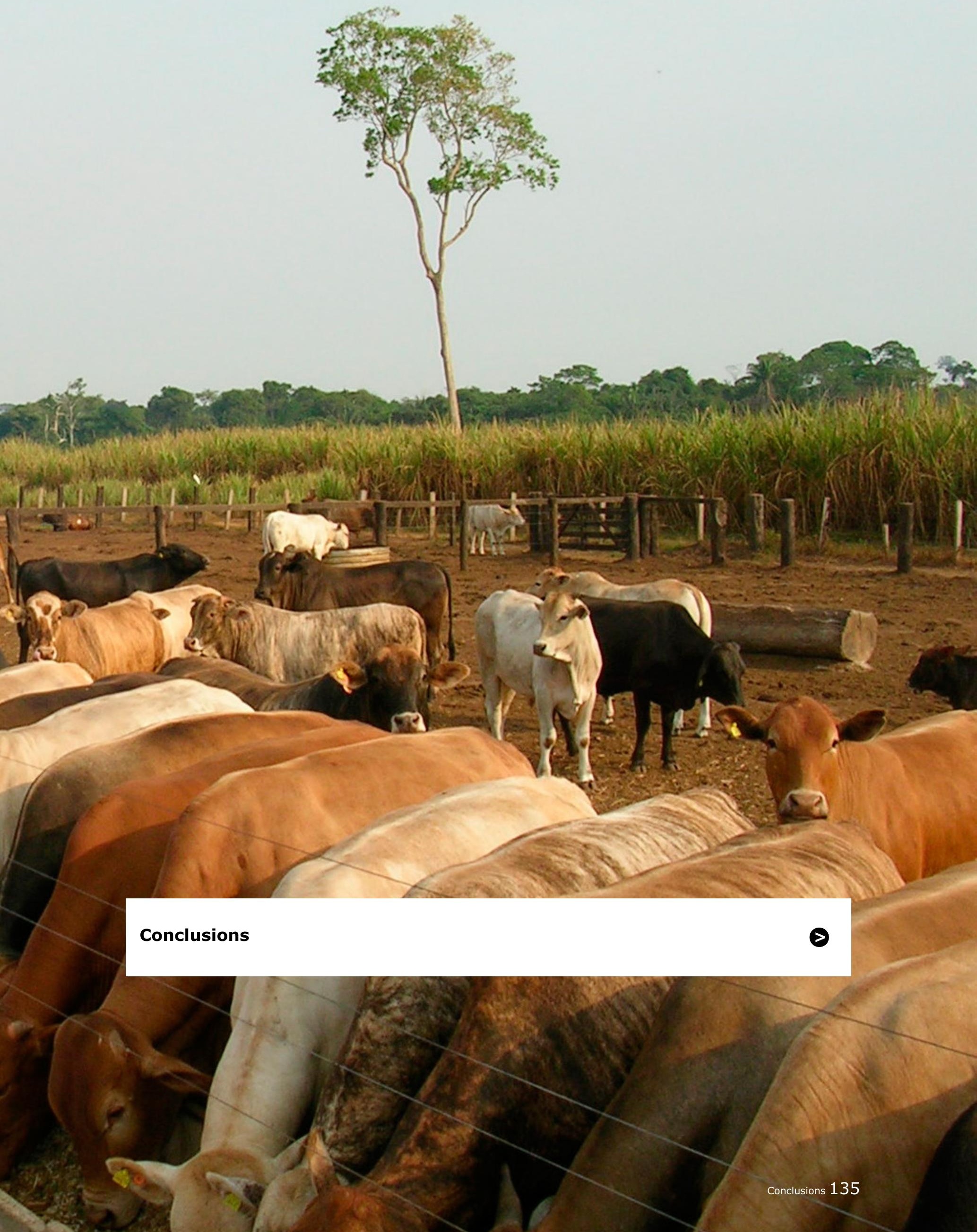




\section{Conclusions}

The livestock sector is a major contributor to the global anthropogenic environmental footprint. The global demand for animal products will grow further in the coming decades due to expanding human populations and an average increase of meat consumption per person. Existing scenarios estimate global demand in 2050 to be $150 \%$ to $200 \%$ of that in 2010 .

The question is whether this growth will lead to further losses of natural capital worldwide, or will we be able to enhance production of animal protein and minimize losses of natural capital at the same time? This study has provided some answers. The analysis includes cattle and poultry production, both at a global level and at specific production systems in different countries and climatic zones and levels of intensification. The impact of livestock systems on social, economic and environmental issues has been quantified where possible. A qualitative assessment has been provided when reliable data was not available. The big picture is clear: animal products are underpriced. Climate change, the loss of ecosystems, air pollution and the impact of water shortages are only some examples of the costs arising from livestock production that were calculated in this study and are ultimately borne by society. We estimated these costs for cattle and poultry to be 2.28 trillion USD per year worldwide, most of it due to beef production. Most of this cost is associated with GHG emissions and land-use change.

In order to understand the implications of this growth we have to zoom in and analyse specific livestock systems. The implications for natural capital of high-input, specialized livestock systems of medium and large scale are reasonably well documented and understood (specialized broiler production and intensive dairy production in our study). These systems reach high productivity levels and rely largely on external inputs, being purchased feed, capital and medicines. These highly specialized systems have the potential to feed large urban populations as they are easy to scale up.

It is a known fact that the production of chicken and milk proteins have a much lower natural capital impact than the production of beef, implying that the internalization of external natural capital costs can be expected to shift the diet towards poultry and dairy. At the same time, there is room for improvement in all livestock systems to reduce the natural capital costs per kilogram of protein. Smallholder livestock systems are a major contributor to the global food supply. In the regions studied we found a great deal of diversity in terms of productivity, impact on climate, water quality and biodiversity, and also a considerable potential for improvement. This potential can be achieved by understanding the options available based on local conditions, measuring the impacts and developing and disseminating best practices. Local conditions that should be taken into account include access to markets, inputs and knowledge, but also climate, local ecosystems and the availability of crop residues. Especially in ruminant systems, there is a win-win situation, as the intensification of systems can reduce GHG emissions per unit of product. So food security and climate change mitigation could be combined in livestock intensification. This is especially the case for smallholder systems in Asia and Africa.

Some subsistence systems were also included in this study. Globally hundreds of millions of farmers are smallholders or pastoralists whose livelihoods depend on livestock. Pastoral cattle and backyard poultry have an extremely low use of inputs, low output levels per animal and low efficiency per kilogram of protein. However, not only do they supply food to the most vulnerable populations, but they are also well adapted to local constraints, generate many side benefits for local poor communities, and usually have a very low or even positive biodiversity impact. These are all aspects of subsistence animal husbandry that are less understood, but not less important. For example, a case study on the Maasai steppe in Tanzania made apparent that pastoralism can conserve measurable ecosystem services and natural capital value, if the alternative is farming that leads to land degradation. These systems are under pressure, especially in rural areas in developing countries. Measures can be taken to assess their importance for the poor and achieve basic improvements in terms of food security and productivity. 
Smallholder livestock production systems can have a high impact on natural capital if they operate on a high input-low output basis per ha of land. In many countries a few dairy cows are kept in non-grazing systems fed with crop residues, grass from roadsides and some concentrates. Production is often low because of the lack of good food and good treatment. Externalities (GHG emissions, N and P leaching) corresponds strongly to the number of animals and less to the production per animal. For these specific cases small is not always beautiful.

The message is clear: the growth of the livestock sector presents many risks for natural capital, but much can be done to address these risks. It is possible to produce animal products for the world population without losing natural capital wealth, as long as the right path is followed. First of all, natural capital has to be fully measured, as its visibility is a requirement for its conservation. Second, a single livestock production system cannot supply animal products to the whole world on its own. The whole range of existing livestock systems will need to contribute as well. As a result, the right improvements need to be identified and pursued for each context, with a location-specific approach. The linkage between livestock, ecosystems and society needs to be valued and understood at the regional level. Finally, livestock systems are key components of agro-ecosystems and under specific management practices can enhance the provision of ecosystem services. Therefore, mechanisms have to be developed to internalize external costs and incentivize good practices, which do not affect food security for the poor. Internalization will help market forces to put the food sector on a more sustainable track, where natural capital wealth is leveraged to create wealth for the current as well as future generations. 


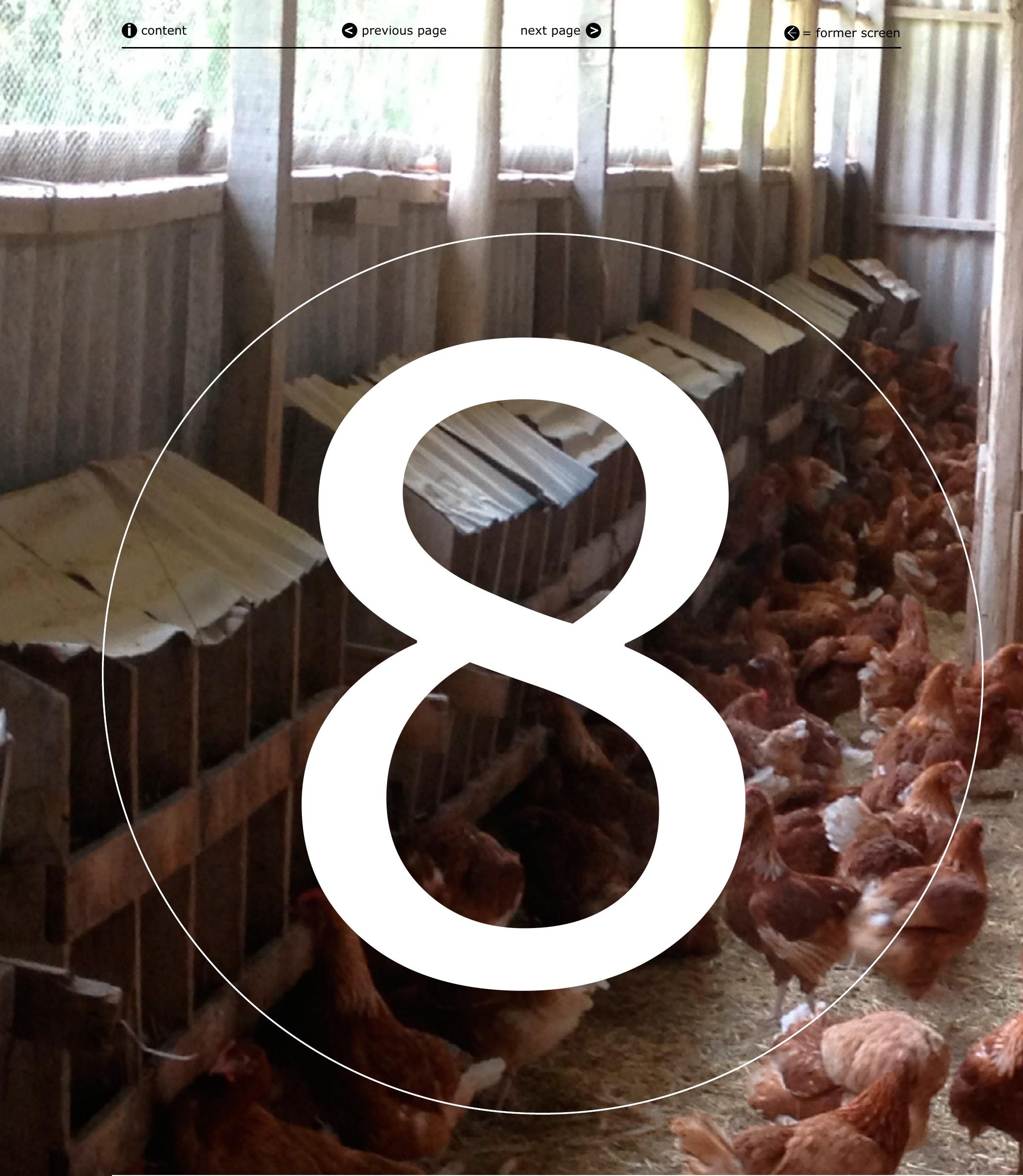




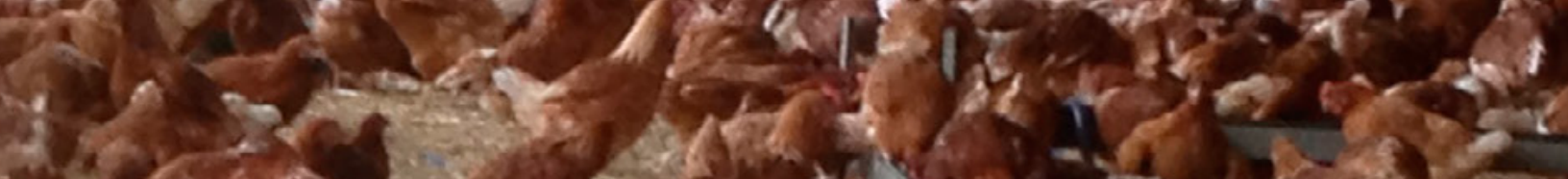
$y+2=$ P.

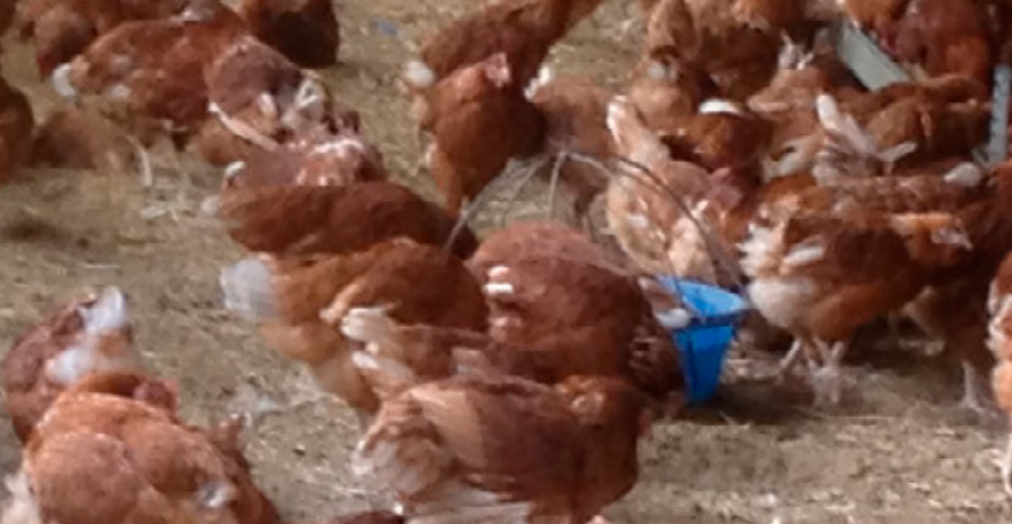

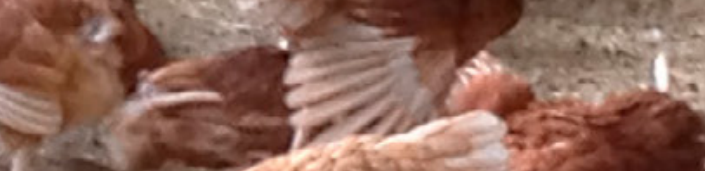

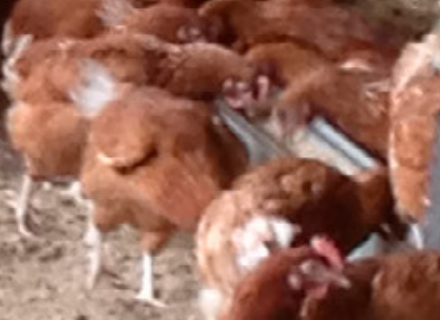

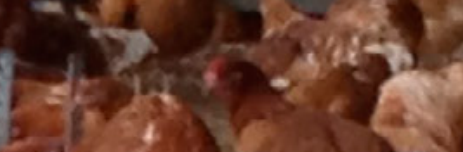

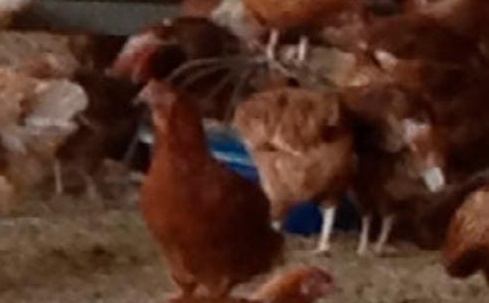
E.

8. â. 


\section{Recommendations}

\subsection{Policy recommendations}

\section{Pay the full price without affecting food security}

- Negative externalities should be internalized in the price of animal products, without affecting food security. This can be done, for example, via voluntary commitments, market measures such as environmental taxation, environmental labelling or environmental regulation. These measures should not increase food prices for vulnerable shares of the population. The internalization of negative externalities will help to steer the livestock sector down a path that minimizes the loss of natural capital.

- The positive externalities of animal husbandry - from managing landscapes to supplying organic fertilizer, from animal traction all the way to fulfilling cultural functions - should be rewarded. These rewards should at least consist of fully recognizing any type of cost-benefit analysis, and at best offer payment for ecosystem services schemes. If positive externalities remain invisible and co-benefits are not encouraged, then the unwanted side effects of improving agricultural systems could lead to a net loss of economic benefits. Financial functions of livestock keeping (= keeping livestock for money) can be a strong barrier to gains in productivity in some areas.

\section{Consolidate valuation of natural capital}

- An important requirement for internalization is that natural capital be consistently measured. Governments should encourage dialogue between different stakeholders, such as international organizations, NGOs, companies and investors, in order to create a standardized valuation framework that would make it possible to monetize the different costs and benefits that affect human well-being as well as ecosystems and biodiversity. This framework will make it possible in the future to simultaneously capture the hidden costs and benefits of livestock systems and the visible costs and benefits, and that, in turn, has given decision-makers the opportunity to start embracing sustainable livestock production practices. The Livestock Environmental Performance and Assessment (LEAP) project aims to build consensus between different stakeholders (governments, the private sector, NGOs and CSOs) on how to measure the environmental impact of livestock. Furthermore, the Natural Capital Coalition and The Sustainability Consortium are great examples of progress in this regard, which can be applied to different industry sectors, not only livestock.

\section{Improve livestock production systems}

- Scenario studies show that increased animal protein production is possible without increasing natural capital costs. Governmental environmental programmes and reduction initiatives should focus on natural capital impacts identified as key contributors to natural capital costs. In this sense, developing and promoting good agricultural practice could contribute greatly to reducing the impacts of livestock on GHG and on the pollution of water bodies. For example, avoiding the excessive fertilization of feed crops, improving manure management or animal diet would decrease GHG emissions of livestock (Opio et al., 2013).

- One of the important pathways is increasing the production per unit of throughput (ha or animal). As a result, more animal proteins can be produced with less input, such as water, minerals, antibiotics, land and energy. This would also decrease natural capital costs per kilogram of animal protein. Sometimes, improving goes hand in hand with an increase in scale of farms and the risks of increasing negative impacts like leaching of minerals or the misuse of antibiotics. Good farming practices like improving pasture management, improving animal health or soil fertility management where feed is produced should be put in place to increase the production without increasing the negative impacts. Improvement options for smallholders must be assessed and identified on a regional basis.

- Policy-makers should promote knowledge-sharing platforms amongst countries, so that technology and farming practices that already exist in developed countries could be applied to decrease natural 
capital impacts in developing countries. Special attention should also be given to the adaptability of those techniques to local conditions. This is particularly important as several BRIC and developing countries are becoming key worldwide livestock producers as a result of rising incomes. For example, Brazil and China are key global contributors to the total natural capital cost for the three livestock commodities analysed, partly due to high production quantities.

\section{Healthy diet: the role of consumers}

- Governments should raise consumer awareness by starting a dialogue on the link between consumers' behaviour, change in diets and natural capital preservation (Bailey et al., 2014). According to the results of this study, diets that would substitute part of beef with chicken consumption are beneficial from a natural capital point of view.

\subsection{Agenda for future research}

This study has tried to help answer the question of how we can sustainably feed the global population with animal proteins without increasing natural capital costs. Still, this question has many more dimensions than those addressed here. Future research should continue to look systematically at the positive and negative impacts on natural capital of livestock production value. This will require expanding the scope and including in the equation issues that have been left out up to this point, from other species to consumption and human health, both affected by animal health and by the ingestion of animal products, from the issue of food waste to water cycle effects, from positive externalities of livestock to other key regions and animal husbandry systems.

\section{Both sides of the coin}

- In the present study, the bottom-up approach was restricted to ten cases only. Worldwide the variation in dairy and beef systems in particular is larger than suggested in this study. Pig meat, small ruminant products and eggs are important contributors to the supply of animal proteins worldwide but had to be left out of the scope of this analysis. Other systems and species also play a role in feeding a growing world population.

- Further analysis, following a continuum of livestock systems in different setting, would be useful. The TEEBAgriFood Valuation Framework makes it possible to compare the sustainability of different livestock production systems.

- The relationship between livestock production and human health is complicated and partly unknown. Because livestock production can influence human health directly by supplying animal proteins and by zoonoses and indirectly by the use of antibiotics its impact can be high. The same reasoning holds for animal and human well-being. It is necessary to include these aspects to get a balanced understanding of the positive and negative impacts of the production of animal proteins on human well-being.

- Grazing and feed production can have an important impact on the water cycle at the regional and national levels because of soil compaction and green and blue water abstraction. These types of negative externalities are also extremely important, as FAO (2006) has pointed out, and should be the object of valuation with a bottom-up approach in order to give a balanced view of the comparison between livestock production systems.

- To quantify the dependency of livestock production systems on ecosystems and biodiversity one should also include soil fertility and green water supply. In order to perform such an analysis data on rainfall, yield and farm economics would be required for all the areas where grazing and feed productions occur.

- Livelihood support, useful animal co-products and carbon storage are all important co-benefits of livestock production that should not be forgotten. Benefits provided by livestock to both the social and environmental realm can be assessed in more detail, monetized more broadly and compared with costs. Assessing all the benefits is the only way to understand the trade-offs faced by millions of farmers, policy-makers and consumers and put the costs in perspective.

- The production of animal protein is strongly guided by consumer demand. A consumer diet that includes more plant protein and less beef, and more milk or poultry meat will influence the expected increase of natural capital costs strongly. Influencing human behaviour regarding diets is extremely difficult and takes time. This is certainly true of consumers in the developed world, whose diet is rich 
in animal proteins, but it also true for consumers in developing countries where the present use of animal protein is still low. Insights on how to influence the human diet in a positive direction are needed to minimize future natural capital costs.

- Further iterations for valuing the impacts of eutrophication could be undertaken in future research. The use of alternative valuation techniques to quantify the impact on ecosystems, such as travel cost, contingent valuation or choice experiments, are areas worth exploring. An example of a future development could be to build a database of eutrophication valuation studies from around the world at a local level, which would integrate changes in nutrient concentrations over time. The consideration of background concentrations would result in a stronger eutrophication valuation, and therefore a more robust comparison of impacts across countries. It would also make it possible to conduct comparisons within regions of the same country and over time. Other future improvements can be made by expanding the scope of the valuation to include other aspects (for example, nitrogen leaching in coastal waters and hypoxia impacts on fish yields), which can be excluded or included according to their applicability in a given country.

\section{The next right questions}

- In this study the focus was on mapping livestock production systems worldwide. The next step could be to systematically compare substitute livestock systems, because it will yield insights that can be used immediately in decision-making. Substitutability happens when systems operate in the same geography or produce the same products for the same market and one can be scaled down and the other scaled up to some extent.

- This study has highlighted that livestock production exists not only in a complex interrelation with natural ecosystems, but also with nearby and faraway crop systems. Looking at combined arable-livestock systems as a whole in more depth could reveal the full benefits of integrating these two activities, which is common practice among smallholder farmers all over the world. This type of complex research faces methodological and data availability challenges, but offers a unique perspective in linking food production and natural capital regeneration from an economic, ecologic and agronomic perspective.

- Smallholder agriculture feeds a significant part of the world population, but whether and how this can be leveraged for natural capital conservation and enhancement is not always clear to policy-makers. Indeed, research linking the economic and social development aspects of smallholder agriculture with environmental considerations is necessary. Monetary valuation is a key tool for understanding these interrelations and making them comparable. We recommend integrating economic, social and environmental aspects in research on smallholder agriculture. This would be useful to understand the costs and benefits of intensification and to look at trade-offs between income and natural capital.

\section{Agriculture for landscape management and the value of ecosystems}

- Livestock and agricultural systems not only provide food, but they also manage landscapes to increase their value in multiple ways. The innovative land valuation framework applied to East African pastoralism can also be used to investigate the value of natural capital assets in other agricultural, natural and semi-natural ecosystems. Research should be put in place to systematically identify and calculate the internal and external natural capital value of key food-producing regions globally and the value of sustainable landscape management. This requires regional data on the natural goods and services grown and used on a specific type of land (provisioning ecosystem services, water supply and agricultural products) and of the sustainability over time of these benefits (related to deforestation, water stress and land degradation trends). 


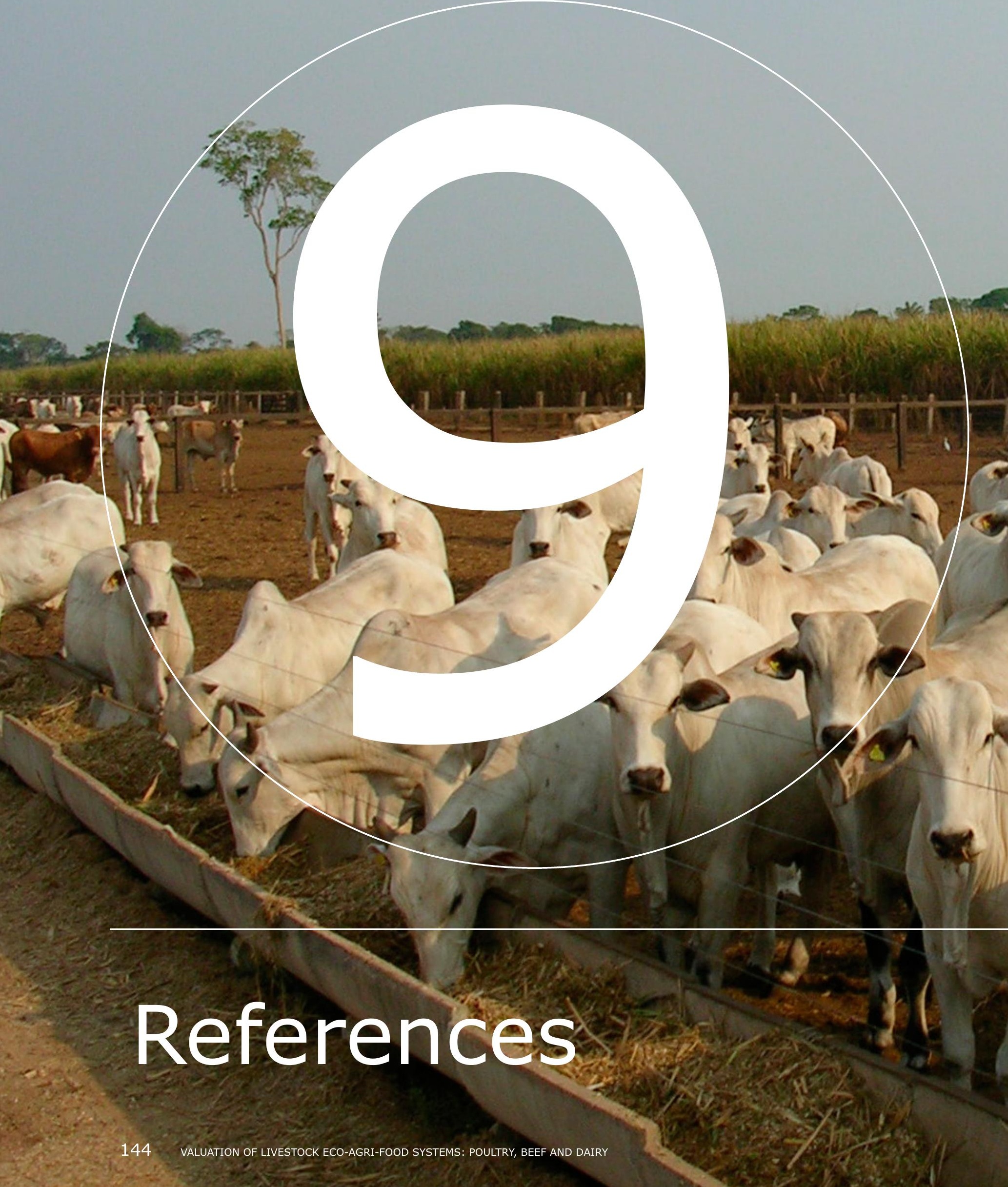


P.

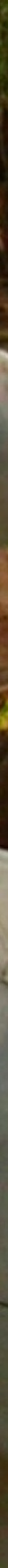


Alexandratos, N., Bruinsma, J., 2012. World agriculture towards 2030/2050: the 2012 revision (ESA Working Paper No. 12-03). FAO, Agricultural Development Economics Division.

Alkemade, R., Reid, R.S., van den Berg, M., de Leeuw, J., Jeuken, M., 2013. Assessing the impacts of livestock production on biodiversity in rangeland ecosystems. Proceedings of the National Academy of Sciences 110, 20900-20905. doi:10.1073/pnas.1011013108

Alkemade, R., van Oorschot, M., Miles, L., Nellemann, C., Bakkenes, M., ten Brink, B., 2009. GLOBIO3: A Framework to Investigate Options for Reducing Global Terrestrial Biodiversity Loss. Ecosystems 12, 374-390. doi:10.1007/s10021-009-9229-5

Animalchange, 2012. Preliminary scenarios of the developments in agricultural commodity markets, livestock production systems, and land use and land cover, Animalchange, seventy framework programme.

Arets, E.J.M.M., Verwer, C., Alkemade, R., 2014. Meta-analysis of the effect of global warming on local species richness (WOt paper No. 34). Statutory Research Tasks Unit for Nature \& the Environment, Wageningen UR.

Aslaksen, I., Framstad, E., Garnåsjordet, P.A., Lillegård, M., 2012a. The Norwegian Nature Index: Expert evaluations in precautionary approaches to biodiversity policy. Norsk Geografisk Tidsskrift

- Norwegian Journal of Geography 66, 257-271. doi:10.1080/00291951.2012.743483

Aslaksen, I., Framstad, E., Garnåsjordet, P.A., Nybø, S., Skarpaas, O., 2012b. Knowledge gathering and communication on biodiversity: Developing the Norwegian Nature Index. Norsk Geografisk Tidsskrift - Norwegian Journal of Geography 66, 300-308. doi:10.1080/00291951.2012. 744092

Bailey, R., Froggatt, A., Wellesley, L., 2014. Livestock - Climate change's forgotten sector. Global public opinion on meat and dairy consumption. Chatham House. The Royal Institute of International Affairs.

Baltussen, W., Beekman, V., de Graaf, R., Borgstein, M., Blokland, P.W., Helming, J., Jongeneel, R., Bondt, N., Oosterkamp, E., van Haaster-de Winter, M., Christodoulou, M., Maréchal, A., de Roest, K., Porcelluzzi, A., Grochowska, R., Seremak-Bulge, J., Szajner, P., Sineiro, F., Lopez, E., Santiso, J., Ratinger, T., Boskova, I., Coutelet, G., Schrijver, R., Dewar, D., 2014. Study on mandatory origin labelling for milk, milk used as an ingredient in dairy products, and unprocessed meat other than beef, pig, poultry, and sheep and goat meat, AGRI - 2013 - EVAL - 03. Stichting Dienst Landbouwkundig Onderzoek, Research Institute LEI, The Hague, The Netherlands.

BEA, 2015. US Department of Commerce. Bureau of Economic Analysis. [Online], Available from: http://www.bea.gov/industry

Bihari, V., Iqbal, S.M., Srivastava, L.P., Kesavachandran, C., 2014. Menstrual impairment among adolescents exposed to biomass fuel smoke. Journal of environmental biology 35.

Bihari, V., Iqbal, S.M., Srivastava, L.P., Kesavachandran, C., Siddique, M.J.A., 2013. Lung function impairment in women exposed to biomass fuels during cooking compared to cleaner fuels in Uttar Pradesh, India. Journal of environmental biology 34, 971-974.

Boki, K.J., 2000. Poultry Industry in Tanzania - with Emphasis on Small-scale Rural Poultry (Proceedings of the Workshop on the Possibilities for Smallholder Poultry Projects in Eastern and Southern Africa). Morogoro, Tanzania.

Bouwman, A.F., Van der Hoek, K.W., Eickhout, B., Soenario, I., 2005. Exploring changes in world ruminant production systems. Agricultural Systems 84, 121-153. doi:10.1016/j.agsy.2004.05.006

Brander, L., 2013. Guidance Manual on Value Transfer Methods for Ecosystem Services. UNEP, Nairobi, Kenya.

Brown, C., 2013. Available Nutrients and Value for Manure From Various Livestock Types (No. order no. 13-043).

Brown, B., 2016. How much fertilizer do your animals produce? University of Wisconsin. [Online], Available from: https://learningstore.uwex.edu/Assets/pdfs/A3601.pdf

Bunce, R.G.H., Pérez-Soba, M., Jongman, R.H.G., Gómez Sal, A., Herzog, F., Austad, I., 2004. Transhumance and Biodiversity in European Mountains. (IALE publication series No. 1).

Carson, R.T., Mitchell, R.C., 1993. The value of clean water: the public's willingness to pay for boatable, fishable and swimmable quality water. Water Resources Research 29, 2445-54. 
Chapin III, F.S., Zavaleta, E.S., Eviner, V.T., Naylor, R.L., Vitousek, P.M., Reynolds, H.L., Hooper, D.U., Lavorel, S., Sala, O.E., Hobbie, S.E., Mack, M.C., Díaz, S., 2000. Consequences of changing biodiversity. Nature 405, 234-242. doi:10.1038/35012241

Deblitz, C., Ostrowski, B., 2004. How competitive is Argentina's beef production? Landbauforschung volkenrode 54, 103-112.

de Groot, R., Brander, L., van der Ploeg, S., Costanza, R., Bernard, F., Braat, L., Christie, M., Crossman, N., Ghermandi, A., Hein, L., Hussain, S., Kumar, P., McVittie, A., Portela, R., Rodriguez, L.C., ten Brink, P., van Beukering, P., 2012. Global estimates of the value of ecosystems and their services in monetary units. Ecosystem Services 1, 50-61. doi:10.1016/j. ecoser.2012.07.005

de Groot, R., Fischer, B., Christie, M., Aronson, J., Braat, L., Gowdy, J., Haines-Young, R., Maltby, E., Neuville, A., Polasky, S., Portela, R., Ring, I., 2010. Chapter 1: Integrating the ecological and economic dimensions in biodiversity and ecosystem service valuation, in: Kumar, P. (Ed.), The Economics of Ecosystems and Biodiversity: The Ecological and Economic Foundations. Earthscan, London and Washington.

Desaigues, B., Ami, D., Hutchison, M., Rabl, A., Chilton, S., Metcalf, H., Hunt, A., Ortiz, R., Navrud, S., Kaderjak, P., Szántó, R., Nielsen, J.S., Jeanrenaud, C., Pellegrini, S., Braun Kohlová, M., Scasny, M., Máca, V., Urban, J., Stoeckel, M.E., Bartczak, A., Markiewicz, O., Riera, P., Farreras, V., 2006. Final Report on the Monetary Valuation of Mortality and Morbidity Risks from Air Pollution. Deliverable RS1b of NEEDS Project.

de Vries, M., de Boer, I.J.M., 2010. Comparing environmental impacts for livestock products: A review of life cycle assessments. Livestock Science 128, 1-11.

EPA, 2015. Agriculture: Ag 101. US Environmental Protection Agency. [Online], Available from: http:// www2.epa.gov/sites/production/files/2015-07/documents/ag_101_agriculture_us_epa_0.pdf

FAO, 2015a. Production quantities by country; [WWW Document]. URL http://faostat3.fao.org/ browse/Q/*/E

FAO, 2015b. Producer prices. Annual [WWW Document]. URL http://faostat3.fao.org/download/P/PP/E

FAO, 2015c. FAOSTAT: Emissions - Agriculture. [WWW Document]. URL http://faostat3.fao.org/browse/ $\mathrm{G} 1 / * / \mathrm{E}$

FAO, 2009a. Livestock in the balance; the state of food and agriculture. Food and agriculture organisation of the united nations, Rome.

FAO, 2009b. Sustaining communities, livestock and wildlife in the Maasai Steppe: vital facts, observations and policy actions. Rome.

FAO, 2006. Livestock's long shadow. Environmental issues and options.

FAO, 2004. Economic valuation of water resources in agriculture: From the sectoral to a functional perspective of natural resource management (FAO Water Reports No. 27).

Ferraz, J.B.S., de Felicio, P.E., 2010. Production systems - An example from Brazil. Meat Science 84, 238-243.

FiBL, 2012. Impact assessment of a global conversion of global livestock production to organic farming. Research Institute of Organic Agriculture (FAO Sustainability and Organic Livestock Model $(\mathrm{SOL}-\mathrm{M}))$.

Garg, M.R., Sherasia, P.L., Bhanderi, B.M., Phondba, B.T., Shelke, S.K., Makkar, H.P.S., 2013. Effects of feeding nutritionally balanced rations on animal productivity, feed conversion efficiency, feed nitrogen use efficiency, rumen microbial protein supply, parasitic load, immunity and enteric methane emissions of milking animals under field conditions. Animal Feed Science and Technology 179, 24-35. doi:10.1016/j.anifeedsci.2012.11.005

Gerber, P., Steinfeld, H., Henderson, B., Mottet, A., Opio, C., Dijkman, J., Falcucci, A., Tempio, G., 2013. Tackling climate change through livestock - A global assessment of emissions and mitigation. Food and Agriculture Organisation of the United Nations, Rome.

Gerber, P., Vellinga, T., Opio, C., Steinfeld, H., 2011. Productivity gains and greenhouse gas emissions intensity in dairy systems. Livestock Science 139, 100-108.

Gibbs, J.P., Halstead, J.M., Boyle, K.J., Huang, J-C., 2002. An Hedonic Analysis of the Effects of Lake Water Clarity on New Hampshire Lakefront Properties. Agricultural and Resource Economics Review 31, 39-46.

Gill, M., Smith, P., Wilkinson, J.M., 2010. Mitigating climate change: the role of domestic livestock. Animal 4, 323-333. 
Haines-Young, R.H., Potschin, M.B., 2009. Methodologies for defining and assessing ecosystem services. (CEM Report No. 24).

Hanafiah, M.M., Hendriks, A.J., Huijbregts, M.A.J., 2012. Comparing the ecological footprint with the biodiversity footprint of products. Journal of Cleaner Production 37, 107-114. doi:10.1016/j. jclepro.2012.06.016

Havenstein, G.B., Ferket, P.R., Qureshi, M.A., 2003. Growth, livability, and feed conversion of 1957 versus 2001 broilers when fed representative 1957 and 2001 broiler diets. Poult. Sci. 82, 1500-1508.

Havlik, P., Valin, H., Mosnier, A., Obersteiner, M., Baker, J.S., Herrero, M., Rufino, M.C., Schmid, E., 2013. Crop Productivity and the Global Livestock Sector: Implications for Land Use Change and Greenhouse Gas Emissions. American Journal of Agricultural Economics 95, 442-448. doi:10.1093/ ajae/aas085

Herrero, M., Havlik, P., McIntire, J., Palazzo, A., Valin, H., 2014. African Livestock Futures: Realizing the potential of livestock for food security, poverty reduction and the environment in Sub-Saharan Africa. Office of the Special Representative of the UN Secretary General for Food Security and Nutrition and the United Nations System Influenza Coordination (UNSIC), Geneva.

Hesse, C., MacGregor, J., 2006. Pastoralism: Drylands' Invisible Asset? (No. 142), Issue paper. iied.

Higgs, S., 2015. Social norms and their influence on eating behaviours. Appetite 86, 38-44. doi: $10.1016 /$ j.appet.2014.10.021

Hoffmann, I., From, T., Boerma, D., 2014. Ecosystem services provided by livestock species and breeds, with special consideration to the contributions of small-scale livestock keepers and pastoralists (No. 66), Background Study Paper. FAO.

Homewood, K., Kristjanson, P., Trench (Eds.), 2002. Staying Maasai? Livelihoods, Conservation and Development in East African Rangelands. Springer, New York.

Horne, P., Achterbosch, T.J., 2008. Animal welfare in poultry production systems: impact of EU standards on world trade. Worlds Poultry Science Journal 64, 40-52.

Huntsinger, L., 2013. California mediterranean rangelands and ecosystem conservation. (Proceedings of the 17th Meeting of the FAO-CIHEAM Mountain Pasture Network - Pastoralism and ecosystem conservation, 5- 7 June 2013, Trivero, Italy, 3-10.

Hussain, S., Miller, D., 2014. TEEB For Agriculture \& Food Concept Note - TEEB. TEEB Advisory Board.

IAASTD, 2009. International assessment of agricultural knowledge, science and technology for development (IAASTD): global report. Washington, DC.

IFPRI, 2008. Overview on Poultry Sector and HPAI Situation for Indonesia with Special Emphasis on the Island of Java. Background Paper (Africa/Indonesia Region Report No. 3).

ILRI, 2015. Unlocking Africa's agricultural potential for transformation to scale African livestock development (No. 18), ILRI policy brief.

IMF, 2015. Market Prices for Non-Fuel and Fuel Commodities, 2012-2015 [WWW Document]. URL http://www.imf.org/external/np/res/commod/index.aspx

IndexMundi, 2015. Animal Numbers, Cattle Production by Country in 1000 HEAD [WWW Document]. URL http://www.indexmundi.com/AGRICULTURE/?commodity=cattle\&graph=production

Instituto de Economía Agrícola, 2015. Preços Mínimo, Mais Comum e Máximo de Venda no Mercado Atacadista de São Paulo [WWW Document]. URL http://ciagri.iea.sp.gov.br/precosdiarios/precosdiariosatacado.aspx

Joon, V., 2014. Non-Invasive Measurement of Carbon Monoxide in Rural Indian Woman Exposed to Different Cooking Fuel Smoke. Aerosol and Air Quality Research. doi:10.4209/aaqr.2013.05.0157

Kantanen, J., Granberg, L., Kopoteva, I., Partanen, U., Pääkkönen, E., Soini, K., 2010. Genetic Uniqueness and Socio-Cultural Conservation Values of the Endangered Yakutian Cattle. MTT Agrifood Research Finland.

Keeler, B.L., Polasky, S., Brauman, K.A., Johnson, K.A., Finlay, J.C., O'Neille, A., Kovacsf, K., Dalzellg, B., 2012. Linking water quality and well-being for improved assessment and valuation of ecosystem services. Proceedings of the National Academy of Sciences of the United States of America.

King, D.M., Mazzotta, M.J., 2000. Ecosystem Valuation [WWW Document]. URL http://www.ecosystemvaluation.org/

Kisungwe, I., 2012. Transforming Traditional poultry keeping into a commercial Venture. RLDC. 
Knueppel, D., Coppolillo, P., Msago, A.O., Msoffe, P., Mutekanga, D., Cardona, C., 2009. Improving Poultry Production for Sustainability in the Ruaha Landscape, Tanzania. USAID.

Kok, M., Alkemade, J.M.R., 2014. How sectors can contribute to sustainable use and conservation of biodiversity. (CDB Technical Series No 79 / PBL report number 01448.). PBL Netherlands Environmental Assessment Agency, The Hague, The Netherlands.

Krysel, C., Boyer, E.M., Parson, C., Welle, P., 2003. Lakeshore property values and water quality: Evidence from property sales in the Mississippi Headwaters Region. Mississippi Headwaters Board and Bemidji State University, Walker MN.

Kshatriya, M., Kifugo, S., Msoffe, F., Neselle, M.O., Said, M.Y., 2007. Mapping Land Cover Changes in Simanjiro and Monduli Districts. International Livestock Research Institute.

Kumar, P., 2010. The Economics of Ecosystems and Biodiversity Ecological and Economic Foundations. Earthscan, London and Washington.

Lawrie, R.A., Ledward, D.A., 2006. Lawrie's Meat Science. Woodhead Publishing, Cambridge.

LEAP, 2015. A review of indicators and methods to assess biodiversity - application to livestock production at global scale. Livestock Environmental Assessment and Performance Partnership (LEAP). FAO, Rome, Italy.

Lesschen, J.P., van den Berg, M., Westhoek, H.J., Witzke, H.P., Oenema, O., 2011. Greenhouse gas emission profiles of European livestock sectors. Animal Feed Science and Technology 166-167, 16-28. doi:10.1016/j.anifeedsci.2011.04.058

Macleod, M., Gerber, P., Mottet, A., Tempio, G., Falcucci, A., Opio, C., Vellinga, T., Henderson, B., Steinfeld, H., 2013. Greenhouse gas emissions from pig and chicken supply chains - A global life cycle assessment. Food and Agriculture Organization of the United Nations (FAO), Rome.

Magothe, T.M., Okeno, T.O., Muhuyi, W.B., Kahi, A.K., 2012. Indigenous chicken production in Kenya: I. Current status. World's Poultry Science Journal 68, 119-132.

Martin-Collado, M., Diaz, C., Drucker, A.G., Carabaño, M.J., Zander, K.K., 2014. Determination of non-market values to inform conservation strategies for the threatened Alistana-Sanabresa cattle breed. Animal. 2014 8(8):1373-81. doi: 10.1017/S1751731114000676. Epub 2014 Apr 3.

Mekkonen, M.M., Hoekstra, A.Y., 2010. The green, blue and grey water footprint of crops and derived crop products (No. 17), Value of Water Research Report Series. UNESCO-IHE, Delft.

Michael, H.J., Boyle, K.J., Bouchard, R., 1996. MR398: Water Quality Affects Property Prices: A Case Study of Selected Maine Lakes (Miscellaneous Report No. 398). Maine Agricultural and Forest Experiment Station, Maine.

MOA, 2015. October first week of livestock and feed markets price situation. [WWW Document]. URL http://www.moa.gov.cn/ztzl/nybrl/rlxx/201510/t20151014_4865249.htm

Mukherjee, S., Roychoudhury, S., Siddique, S., Banerjee, M., Bhattacharya, P., Lahiri, T., Ray, M.R., 2014. Respiratory symptoms, lung function decrement and chronic obstructive pulmonary disease in pre-menopausal Indian women exposed to biomass smoke. Inhalation Toxicology 26, 866-872. doi:10.3109/08958378.2014.965560

Myers, N., Mittermeier, R.A., Mittermeier, C.G., da Fonseca, G.A.B., Kent, J., 2000. Biodiversity hotspots for conservation priorities. Nature 403, 853-858.

National Dairy Development Board, 2012. National Dairy Plan.

NCC, 2014. Natural Capital Coalition (NCC). What is natural capital. [Online], Available from: http:// www. naturalcapitalcoalition.org/why-natural-capital/natural-capital.html

Nelson, F., 2012. Natural conservationists? Evaluating the impact of pastoralist land use practices on Tanzania's wildlife economy. 12 2. [WWW Document]. URL http://www.naturalcapitalcoalition.org/ why-natural-capital/natural-capital.html

Newbold, T., Hudson, L.N., Hill, S.L.L., Contu, S., Lysenko, I., Senior, R.A., Börger, L., Bennett, D.J., Choimes, A., Collen, B., Day, J., De Palma, A., Díaz, S., Echeverria-Londoño, S., Edgar, M.J., Feldman, A., Garon, M., Harrison, M.L.K., Alhusseini, T., Ingram, D.J., Itescu, Y., Kattge, J., Kemp, V., Kirkpatrick, L., Kleyer, M., Correia, D.L.P., Martin, C.D., Meiri, S., Novosolov, M., Pan, Y., Phillips, H.R.P., Purves, D.W., Robinson, A., Simpson, J., Tuck, S.L., Weiher, E., White, H.J., Ewers, R.M., Mace, G.M., Scharlemann, J.P.W., Purvis, A., 2015. Global effects of land use on local terrestrial biodiversity. Nature 520, 45-50. doi:10.1038/ nature 14324

New Zealand Trade and Enterprise, 2010. Exporter guide: Dairy market in Brazil; market profile. 
Oenema, O., Tamminga, S., 2005. Nitrogen in global animal production and management options for improving nitrogen use efficiency. Science in China 48, 871-887.

OiE, 2015. The world animal health information system [WWW Document]. URL http://www.oie.int/ animal-health-in-the-world/the-world-animal-health-information-system/the-oie-data-system/

Olson, D.M., Dinerstein, E., Wikramanayake, E.D., Burgess, N.D., Powell, G.V., Underwood, E.C., D'Amico, J.A., Itoua, I., Strand, H.E., Morrison, J.C., Loucks, C.J., Allnutt, T.F., Ricketts, T.H., Kura, Y., Lamareux, J.F., Wettengel, W.W., Hedao, P., Kassem, K.R., 2001. Terrestrial Ecoregions of the World: A New Map of Life on Earth. BioScience 51, 933-938.

Opio, C., Gerber, P., Mottet, A., Falcucci, A., Tempio, G., MacLeod, M., Vellinga, T., Henderson, B., Steinfeld, H., 2013. Greenhouse gas emissions from ruminant supply chains - A global life cycle assessment. Food and Agriculture Organization of the United Nations (FAO), Rome.

Ovaska, U., Soini, K., 2011. The Conservation of Values of Yakutian Cattle (No. 49), Animal Genetic Resources.

Parmesan, C., Yohe, G., 2003. A globally coherent fingerprint of climate change impacts across natural systems. Nature 421, 37-42. doi:10.1038/nature01286

Pascual, U., Muradian, R., Brander, L., Gómez-Baggethun, E., Martín-López, B., Verma, M., Armsworth, P., Christie, M., Cornelissen, H., Eppink, F., Farley, J., Loomis, J., Pearson, L., Perrings, C., Polasky, S., 2010. The economics of valuing ecosystem services and biodiversity, in: Kumar, P. (Ed.), The Economics of Ecosystems and Biodiversity: The Ecological and Economic Foundations.

Perevolotsky, A., Seligman, N.G., 1998. Role of Grazing in Mediterranean Rangeland Ecosystems. BioScience 48, 1007-1017.

Petz, K., Alkemade, R., Bakkenes, M., Schulp, C.J.E., van der Velde, M., Leemans, R., $2014 a$. Mapping and modelling trade-offs and synergies between grazing intensity and ecosystem services in rangelands using global-scale datasets and models. Global Environmental Change 29, 223-234. doi:10.1016/j.gloenvcha.2014.08.007

Petz, K., Glenday, J., Alkemade, R., 2014b. Land management implications for ecosystem services in a South African rangeland. Ecological Indicators 45, 692-703. doi:10.1016/j.ecolind.2014.05.023

Pfister, S., 2011. Environmental evaluation of freshwater consumption within the framework of life cycle assessment. DISS. ETH NO. 19490. ETH ZURICH.

Philippot, A., Aguilar, F., Zou, L., Gupta, N., Liu, Z., 2011. Competitiveness Analysis of The Netherlands and the Dutch Dairy Cluster. Microeconomics of Competitiveness; Microeconomics of Competitiveness [WWW Document]. URL http://www.isc.hbs.edu/resources/courses/moc-courseat-harvard/Documents/pdf/student-projects/Netherlands_Dairy_2011.pdf

Potter, P., Ramankutty, N., Bennett, E.M., Donner, S.D., 2010. Characterizing the Spatial Patterns of Global Fertilizer Application and Manure Production. Earth Interactions 14, 1-22. doi:10.1175/2009EI288.1

Reid, R.S., Bedelian, C., Said, M.Y., Kruska, R.L., Mauricio, R.M., Castel, V., Olson, J., Thornton, P.K., 2010. Global Livestock Impacts on Biodiversity., in: Steinfeld, H., Mooney, A., Schneider, F., Neville (Eds.), Livestock in a Changing Landscape. Volume 1. Drivers, Consequences and Responses. Washington, USA.

Reidsma, P., Tekelenburg, T., van den Berg, M., Alkemade, R., 2006. Impacts of land-use change on biodiversity: An assessment of agricultural biodiversity in the European Union. Agriculture, Ecosystems \& Environment 114, 86-102. doi:10.1016/j.agee.2005.11.026

Reijnen, M.J.S.M., Hinsberg, A. van, Esbroek, M.L.P., Knegt, B. de, Pouwels, R., Tol, S. van, Wiertz, J., 2010. Natuurwaarde 2.0 land: graadmeter natuurkwaliteit landecosystemen voor nationale beleidsdoelen (WOT rapport No. 210). Wageningen UR, Wageningen.

Robinson, T.P., P.K., T., Franceschini, G., Kruska, R.L., Chiozza, F., Notenbaert, A., Cecchi, G., Herrero, M., Epprecht, M., Fritz, S., You, L., Conchedda, G., See, L., 2011. Global livestock production systems. Rome.

Robinson, T.P., Wint, G.R.W., Conchedda, G., Boeckel, T.P.V., Ercoli, V., Palamara, E., Cinardi, G., D'Aietti, L., Hay, S.I., Gilbert, M., 2014. Mapping the Global Distribution of Livestock. PLoS ONE 9. 
Sala, O.E., Chapin III, F.S., Armesto, J.J., Berlow, E., Bloomfield, J., Dirzo, R., Huber-Sandwald, E., Huenneke, L.F., Jackson, R.B., Kinzig, A., Leemans, R., Lodge, D.M., Mooney, H.A., Oesterheld, M., Poff, N.L., Walker, B.H., Walker, M., Wall, D.H., 2000. Global Biodiversity Scenarios for the Year 2100. Science 287, 1770-1774. doi:10.1126/science.287.5459.1770

Santana, Carlos Augusto M., Torres, D.A.P., Guiducci, R. do C.N., da Silva Alves, M.A., Garagorry, F.L., da Silva e Souza, G., Delgado Assad, E., Pellegrino, G.Q., Barioni, L.G., Oliveira de Souza, M., Chaib Filho, H., Marra, R., Mota, M.M., 2010. Productive capacity of Brazilian agriculture: a long-term perspective. Regional study for UK FORESIGHT Project on Global Food and Farming Futures. Government Office of Science, London.

Seré, C., Steinfeld, H., 1996. World Livestock Production Systems; Current status, issues and trends (FAO Animal Production and Health Paper No. 127).

Singh, S., Gupta, G.P., Kumar, B., Kulshrestha, U.C., 2014. Comparative study of indoor air pollution using traditional and improved cooking stoves in rural households of Northern India. Energy for Sustainable Development 19, 1-6. doi:10.1016/j.esd.2014.01.007

Soussana, J.-F., 2012. Storylines for the livestock sector scenarios in EU, studied SICA regions and global level (Deliverable FP7 AnimalChange). INRA /DLO.

Sumba, D., Bergin, P., Jones, C., 2005. Land Conservation Trusts : A Case Study of Manyara Ranch, Tanzania. AWF Working Papers.

Sumiarto, B., Arafin, B., 2008. Overview on Poultry Sector and HPAI Situation for Indonesia with Special Emphasis on the Island of Java $\square$ Background Paper, Africa/Indonesia Region Report. FAO, RDRC, IFPRI and ILRI.

Suttie, J.M., Reynolds, S.G., Batello, C. (Eds.), 2005. Grasslands of the world, Plant Production and Protection Series. Food and Agriculture Organization of the United Nations (FAO), Rome.

Swai, E.S., Karimuribo, E.D., 2011. Smallholder dairy farming in Tanzania Current profiles and prospects for development. Outlook on Agriculture 40, 21-27.

TEEB, 2015. TEEB for Agriculture \& Food: an interim report, United Nations Environment Programme, Geneva, Switzerland. http://www.teebweb.org/publication/towards-teebagfood/

ten Brink, B., Alkemade, J.R.M., Bakkenes, M., Clement, J., Eickhout, B., Fish, L., de Heer, M., Kram, T., Manders, T., van Meijl, H., Miles, L., Nellemann, C., Lysenko, I., van Oorschot, M., Smout, F., Tabeau, A., van Vuuren, D., Westhoek, H., 2007. Cross-roads of Life on Earth: Exploring means to meet the 2010 Biodiversity Target. (No. 31), CBD Technical Series. Secretariat of the Convention on Biological Diversity.

ten Brink, B., van der Esch, S., Kram, T., van Oorschot, M., 2010. Rethinking Global Biodiversity Strategies: Exploring structural changes in production and consumption to reduce biodiversity loss. Netherlands Environmental Assessment Agency, Bilthoven, the Netherlands.

Thoma, G., Popp, J., Shonnard, D., Ulrich, R., Matlock, M., Kim, D.S., Neiderman, Z., Kemper, N., East, C., Adom, F., 2013. Greenhouse gas emissions from milk production and consumption in the United States: A cradle-to-grave life cycle assessment circa 2008. International Dairy Journal $31, \mathrm{~S} 3-\mathrm{S} 14$.

Thompson, C., Johnson, B., 2012. The Value of Water in Agricultural Land Markets: The Nebraska Case. Journal of the ASFMRA. University of Nebraska, Department of Agriculture Economics.

Thornton, P.K., 2010. Livestock production: recent trends, future prospects. Philosophical Transactions of the Royal Society B: Biological Sciences 365, 2853-2867. doi:10.1098/rstb.2010.0134

Thornton, P.K., Kruska, R.L., Henninge, N., Krisjanson, P.M., Reid, R.S., Atieno, A.N., Odero, N., Ndegwa, T., 2002. Mapping poverty and livestock in the developing world. ILRI, Nairobi, Kenya.

Trucost, 2016. Top-down methodology TEEB Animal Husbandry. Trucost, London, United Kingdom.

Trucost, 2013. Natural Capital at Risk: the Top 100 Externalities of Business. Trucost, London, United Kingdom.

True Price, 2016. Bottom-up methodology TEEB Animal Husbandry. True Price Foundation, Amsterdam The Netherlands.

UK Foresight, 2011. Global Food and Farming Futures. Government Office of Science, London, UK.

UNEP-IHDP, UNEP, 2014. Inclusive Wealth Report 2014: measuring progress toward sustainability. Cambridge University Press, Cambridge.

UNEP-IHDP, UNEP, 2012. Inclusive Wealth Report 2012: measuring progress toward sustainability. Cambridge University Press, Cambridge. 
UN/EU/FAO/IMF/OECD/WorId Bank, 2014a. System of environmental-economic accounting 2012

- Central framework.

UN/EU/FAO/IMF/OECD/World Bank, 2014b. System of environmental-economic accounting 2012

- Applications and extensions.

UN/EU/FAO/IMF/OECD/World Bank, 2014c. System of environmental-economic accounting 2012

- Experimental Ecosystem Accounting.

USAID, 2013. Indonesia's poultry value chain: costs, margins, prices, and other issues.

USDA, 2015. Meat Price Spreads: Overview. [WWW Document]. URL http://www.ers.usda.gov/data-products/meat-price-spreads.aspx

USDA, 2013. Fertilizer Use and Price: Table 7-Average U.S. farm prices of selected fertilizers, 19602013. [Online]. Available from: http://www.ers.usda.gov/data-products/fertilizer-use-and-price. aspx\#26727

USDA, 2012. Overview. United States Department of Agriculture Economic Research Service.

USIAWG, 2013. Technical Support Document: Technical Update of the Social Cost of Carbon for Regulatory Impact Analysis Under Executive Order 12866. Interagency Working Group on Social Cost of Carbon, United States Government, Washington, DC.

Valin, H., Sands, R.D., van der Mensbrugghe, D., Nelson, G.C., Ahammad, H., Blanc, E., Bodirsky, B., Fujimori, S., Hasegawa, T., Havlik, P., Heyhoe, E., Kyle, P., Mason-D'Croz, D., Paltsev, S., Rolinski, S., Tabeau, A., van Meijl, H., von Lampe, M., Willenbockel, D., 2014. The future of food demand: understanding differences in global economic models. Agricultural Economics 45, 51-67. doi:10.1111/agec.12089

Vesterinen, J., Pouta, E., Huhtala, A., Neuvonen, M., 2010. Impacts of changes in water quality on recreation behavior and benefits in Finland. Journal of Environmental Management 91, 984-994. doi:10.1016/j.jenvman.2009.12.005

Wageningen UR, 2015a. MARAN - Antibiotic usage [WWW Document]. URL http://www.wageningenur. $\mathrm{nl} / \mathrm{en} /$ Research-Results/Projects-and-programmes/MARAN-Antibiotic-usage.htm

Wageningen UR, 2015b. Strategic Plan 2015-2018 http://www.wageningenur.nl/en/AboutWageningen-UR/Strategic-Plan.htm

Warren, R., Price, J., Fischlin, A., de la Nava Santos, S., Midgley, G., 2011. Increasing impacts of climate change upon ecosystems with increasing global mean temperature rise. Climatic Change 106, 141-177. doi:10.1007/s10584-010-9923-5

Weidema, B.P., 2009. Using the budget constraint to monetarise impact assessment results. Ecol Econ 68:1591-1598

Westhoek, H., Rood, T., van den Berg, M., Janse, J., Nijdam, D., Reudink, M., Stehfest, E., 2011. The protein puzzle; The consumption and production of meat, dairy and fish in the European Union. PBL Netherlands Environmental Assessment Agency, The Hague, The Netherlands.

Williams, A.G., Audsley, E., Sandars, D.L., 2006. Determining the environmental burdens and resource use in the production of agricultural and horticultural commodities., Main Report. Defra Research Project IS0205. Cranfield University and Defra, Bedford.

Wint, G.R.W., Robinson, T.P., 2007. Gridded livestock of the world 2007. Rome.

World Bank, 2015a. Consumer price index $(2010=100)$. [Online]. Available from: http://data. worldbank.org/indicator/FP.CPI.TOTL

World Bank, 2015b. Price level ratio of PPP conversion factor (GDP) to market exchange rate [WWW Document]. URL http://data.worldbank.org/indicator/PA.NUS.PPPC.RF (accessed 3.17.15)

WRI, 2013. Aqueduct Global Maps 2.0. Working paper. Baseline Water Stress. Washington DC: World Resource Institute.

Zander, K.K., Signorello, G., De Salvo, M., Gandini, G. and Drucker, A.G. 2013. Assessing the total economic value of threatened livestock breeds in Italy. Ecological Economics 93: 219-229. 
as $x^{2}$

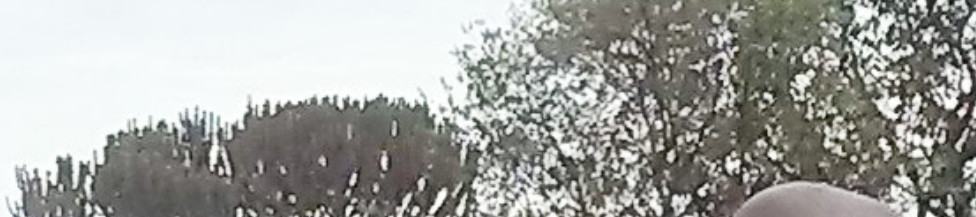
tian

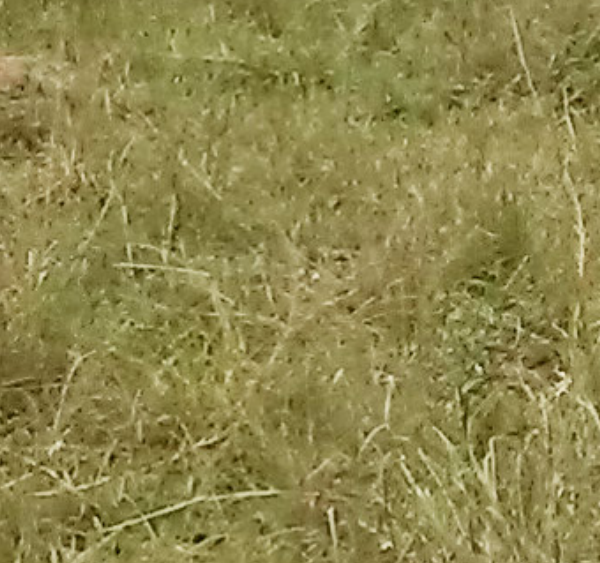

$\left.i^{4}\right)^{2}+\frac{1}{2}$

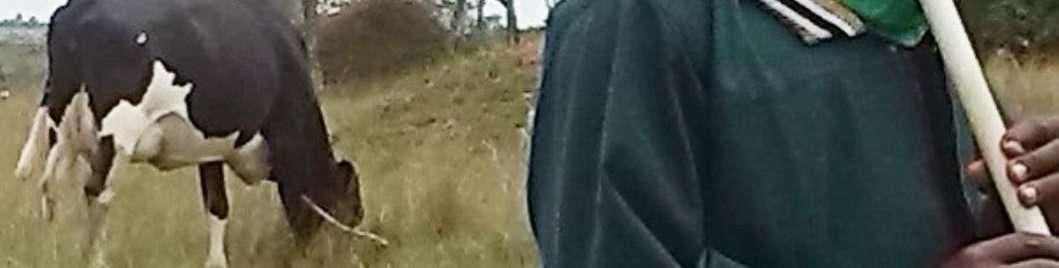




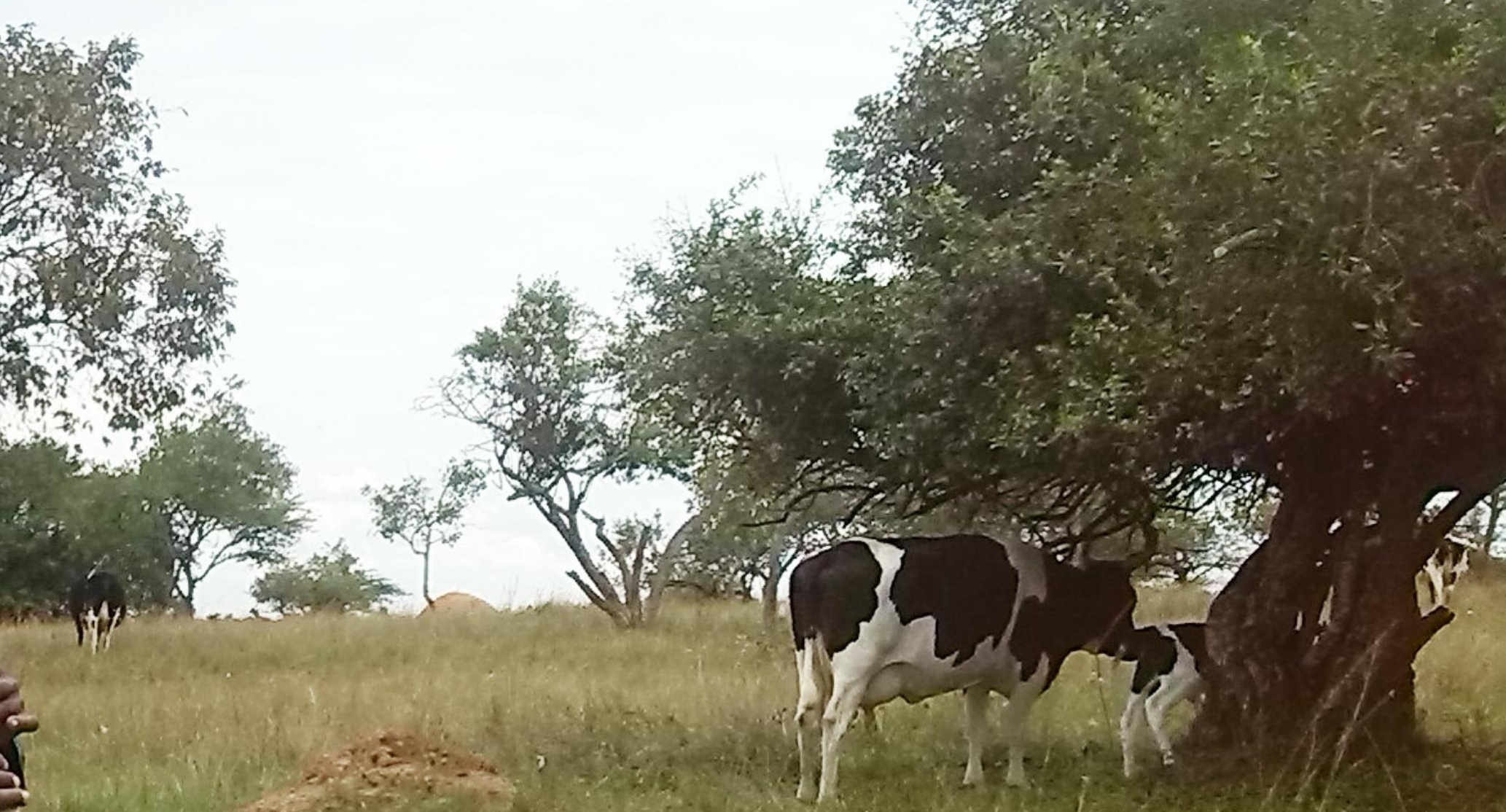

\section{Annex A \\ Livestock production system indicators per snapshot}

$\bullet$

Annex B

Comparison bottom-up and top-down methodologies and results

$\nabla$

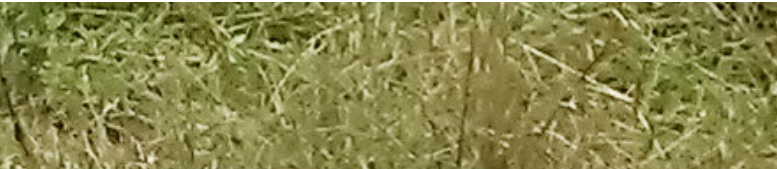


A Annex:

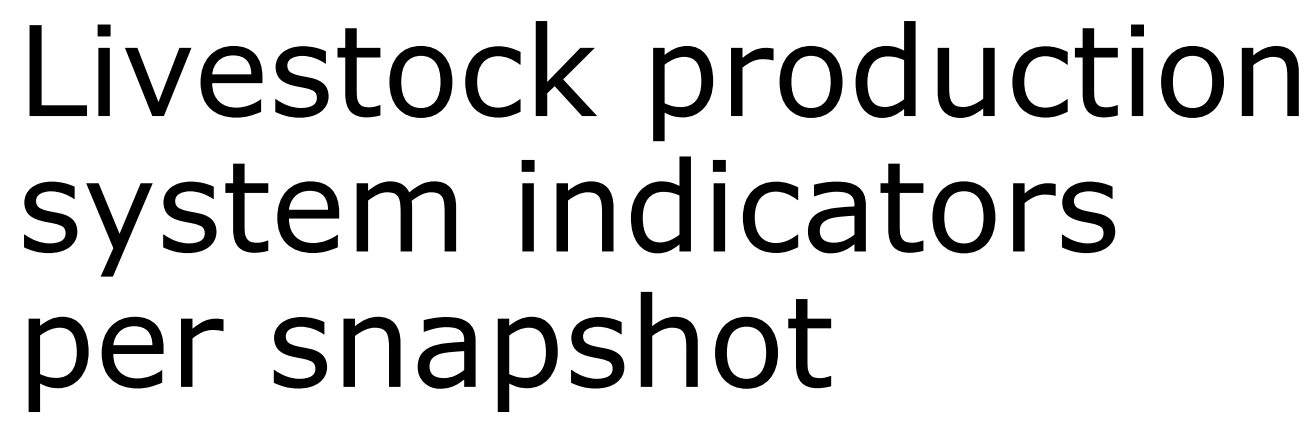

Table A.1 Herd parameters

\begin{tabular}{|c|c|c|c|c|c|c|c|c|c|c|c|c|c|}
\hline snapshot & 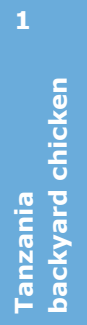 & 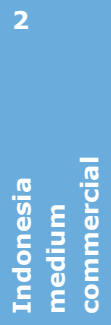 & 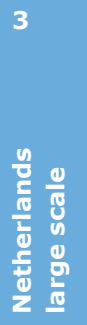 & 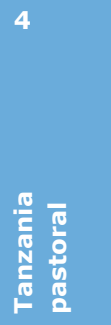 & 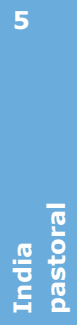 & 를 & 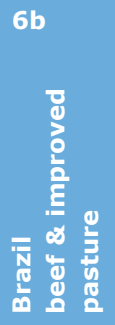 & 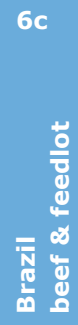 & 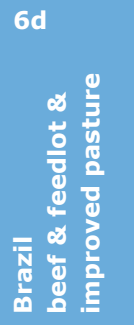 & 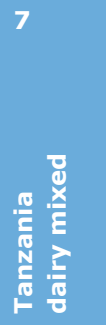 & 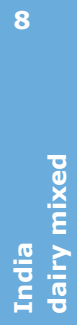 & 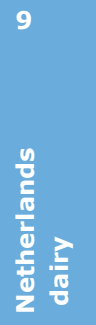 & 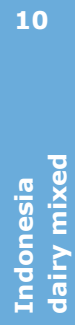 \\
\hline dairy cows & & & & & & & & & & 5 & 5 & 85 & 5 \\
\hline herd size & 100 & 5000 & 90000 & 300 & 100 & 300 & 300 & 300 & 330 & 8 & 8 & 160 & 8 \\
\hline head $/ \mathrm{km}^{2}$ & & & & 12 to 15 & $\begin{array}{l}20 \text { to } \\
70\end{array}$ & $\begin{array}{l}90 \text { to } \\
110\end{array}$ & $\begin{array}{l}90 \text { to } \\
110\end{array}$ & $\begin{array}{l}90 \text { to } \\
110\end{array}$ & 110 to 120 & 20 to 25 & $\begin{array}{l}10 \text { to } \\
20\end{array}$ & $\begin{array}{l}150 \text { to } \\
250\end{array}$ & $\begin{array}{l}50 \text { to } \\
90\end{array}$ \\
\hline $\begin{array}{l}\text { adult weight } \\
\text { female }(\mathrm{kg})\end{array}$ & 1.35 & 1.65 & 3.8 & 320 & 478 & 500 & 500 & 500 & 500 & 320 & 350 & 555 & 350 \\
\hline $\begin{array}{l}\text { adult weight } \\
\text { male }(\mathrm{kg})\end{array}$ & 1.92 & 1.85 & 4.85 & 416 & 500 & 650 & 650 & 650 & 650 & 450 & 500 & 722 & 500 \\
\hline $\begin{array}{l}\text { birth weight } \\
(\mathrm{kg})\end{array}$ & 0.025 & 0.04 & 0.04 & 25 & 31 & 33 & 33 & 33 & 33 & 20 & 30 & 40 & 30 \\
\hline $\begin{array}{l}\text { DR birth } \\
\text { female (\%) }\end{array}$ & 50 & 0 & 0 & 21 & 24 & 15 & 15 & 15 & 15 & 20 & 22 & 8 & 20 \\
\hline $\begin{array}{l}\text { DR birth } \\
\text { male (\%) }\end{array}$ & 50 & 0 & 0 & 21 & 44 & 15 & 15 & 15 & 15 & 20 & 52 & 8 & 20 \\
\hline DR older $(\%)$ & 20 & 5 & 3.5 & 7 & 10 & 5 & 5 & 5 & 5 & 7 & 8 & 4 & 7.5 \\
\hline AFC (year) & 0.46 & 0.48 & 0.42 & 4 & 3.6 & 3.3 & 3 & 3 & 3 & 4 & 3.1 & 2 & 3.1 \\
\hline $\begin{array}{l}\text { slaughter } \\
\text { weight }\end{array}$ & 1.27 & 1.48 & 1.56 & 309 & 286 & 483 & 483 & 483 & 329 & 369 & 364 & 200 & 389 \\
\hline hatchability & 0.8 & 0.8 & 0.8 & & & & & & & & & & \\
\hline eggs/year & 50 & 160 & 160 & & & & & & & & & & \\
\hline eggs/clutch & 13 & & & & & & & & & & & & \\
\hline clutches & 3 & & & & & & & & & & & & \\
\hline $\begin{array}{l}\text { Fertility rate } \\
(\%)\end{array}$ & - & & & 75 & 75 & 75 & 75 & 75 & 75 & 75 & 75 & 65 & 70 \\
\hline $\begin{array}{l}\text { Replacement } \\
\text { rate }(\%)\end{array}$ & 33 & 100 & 100 & 10 & 15 & 11 & 11 & 11 & 11 & 10 & 20 & 33 & 20 \\
\hline
\end{tabular}




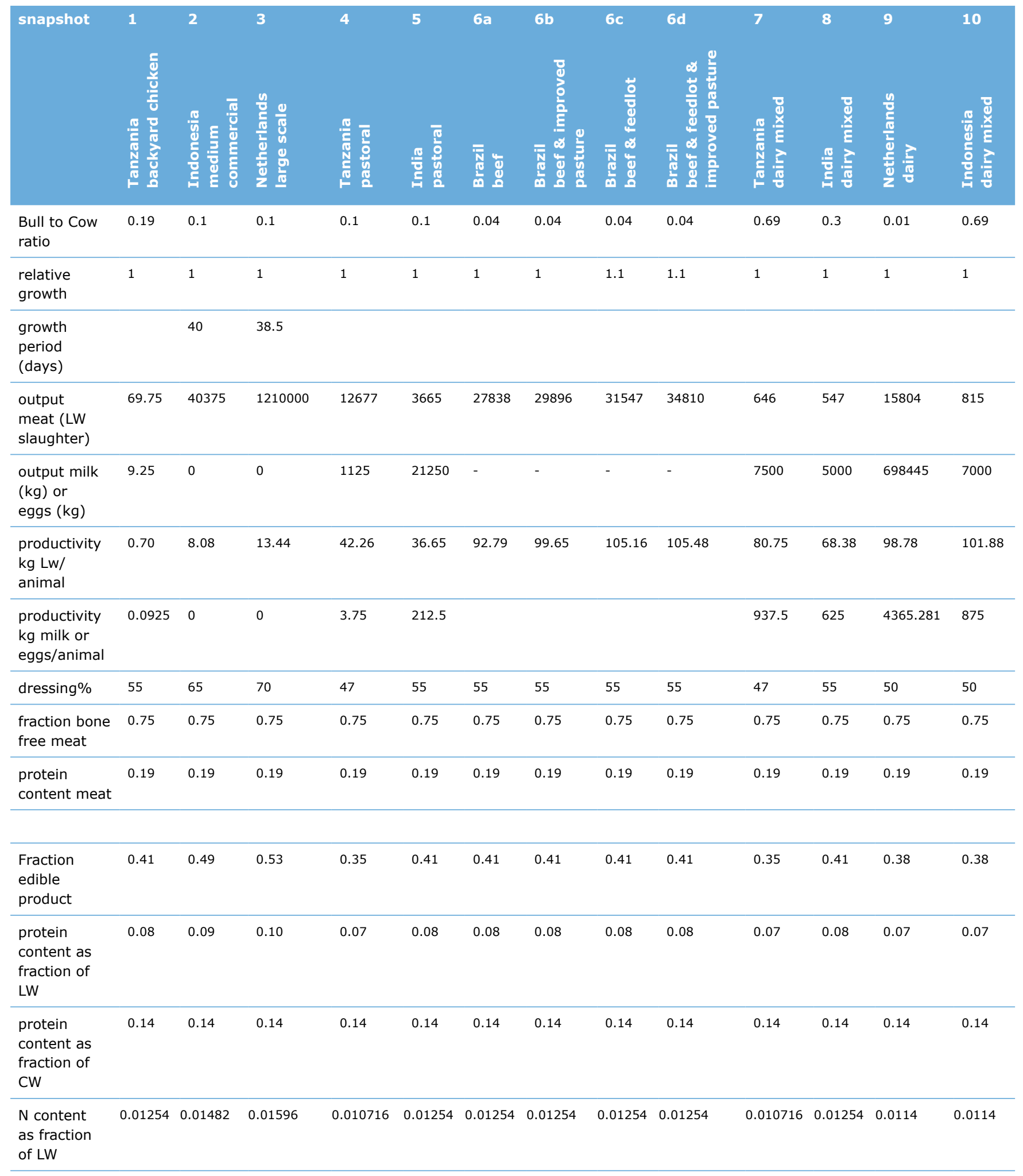


Table A.2 Animals rations (feed by type in \% of total feed intake in $\mathrm{kg}$ per animal)

\begin{tabular}{|c|c|c|c|c|c|c|c|c|c|c|c|c|c|}
\hline Snapshot & 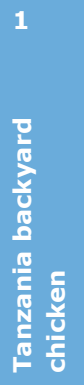 & 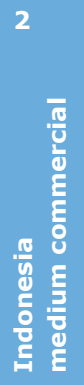 & 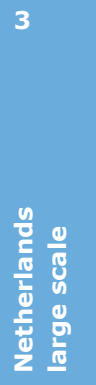 & 4 & 5 & $\begin{array}{l}6 \mathrm{a} \\
\\
\overline{\mathrm{N}} \\
\frac{\mathrm{N}}{\mathrm{m}} \\
\overline{0}\end{array}$ & 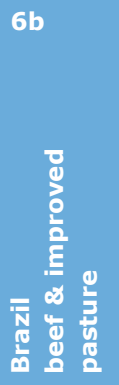 & 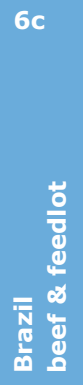 & 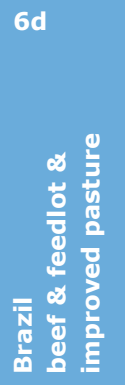 & 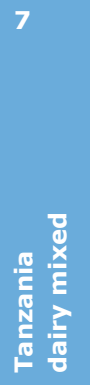 & 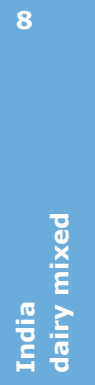 & 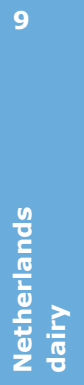 & 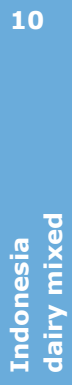 \\
\hline $\begin{array}{l}\text { Fresh } \\
\text { grass }\end{array}$ & & & & 90 & 85 & 95 & 90 & 80 & 80 & 24 & 11 & 33.2 & 8 \\
\hline Hay & & & & & & 5 & 5 & 5 & 5 & & & 16.6 & \\
\hline $\begin{array}{l}\text { Legumes/ } \\
\text { silage }\end{array}$ & & & & - & & - & & & & & & 22.6 & \\
\hline $\begin{array}{l}\text { Crop } \\
\text { residues }\end{array}$ & & & & 10 & 5 & & & & & 70 & 70 & 2.5 & 70 \\
\hline $\begin{array}{l}\text { Sugarcane } \\
\text { tops }\end{array}$ & & & & & & & & & & 0 & 5 & - & 3 \\
\hline Leaves & & & & & 10 & & & & & 0 & 5 & - & 5 \\
\hline $\begin{array}{l}\text { Wet } \\
\text { distillers } \\
\text { grain }\end{array}$ & & & & - & & & & 1 & 1 & - & - & - & - \\
\hline Molasses & & & & - & - & - & & 1 & 1 & & 1 & 0.1 & - \\
\hline Fruit pulp & & & & - & - & - & & 1 & 1 & - & - & 1.3 & - \\
\hline Swill & 40 & & & & & & & & & & & & \\
\hline Pulses & 2 & & & & & & & & & & & & \\
\hline Cassava & 8 & & & & & & & & & & & & \\
\hline Wheat & 1 & 13 & 40 & & & & & & & & & & \\
\hline Maize & 11 & 47 & 24 & & & & & 8 & 8 & 2 & 2 & 13.2 & 7 \\
\hline Barley & - & 4 & & & & & & & & & & & \\
\hline Millet & 3 & & & & & & & & & & & & \\
\hline Rice & 3 & & & & & & & & & & & & \\
\hline Sorghum & 3 & 7 & 5 & & & & & & & & & & \\
\hline Soybean & - & & 15 & & & & & & & & & & \\
\hline $\begin{array}{l}\text { Soybean } \\
\text { meal }\end{array}$ & 2 & 25 & 10 & & & & & & & & & & \\
\hline $\begin{array}{l}\text { Meal } \\
\text { oilseeds }\end{array}$ & 11 & 1 & 2 & & & & 3 & 4 & 4 & 3 & 5 & 8.5 & 7 \\
\hline $\begin{array}{l}\text { Meal } \\
\text { cotton- } \\
\text { seed }\end{array}$ & 6 & & & & & & & & & & & & \\
\hline $\begin{array}{l}\text { Grain by } \\
\text { products }\end{array}$ & 11 & & & - & & & 2 & & & 1 & 1 & 2 & \\
\hline Fishmeal & & 1 & & & & & & & & & & & \\
\hline $\begin{array}{l}\text { Synthetic } \\
\text { Amino } \\
\text { acids }\end{array}$ & & 1 & 1 & & & & & & & & & & \\
\hline Rapeseed & & & 1 & & & & & & & & & & \\
\hline $\begin{array}{l}\text { Rapeseed } \\
\text { meal }\end{array}$ & & & 1 & & & & & & & & & & \\
\hline Lime & & 1 & 1 & & & & & & & & & & \\
\hline
\end{tabular}


Table A.3 Food Conversion Rate (FCR)

\begin{tabular}{|c|c|c|c|c|c|c|c|c|c|c|c|c|c|}
\hline Snapshot & 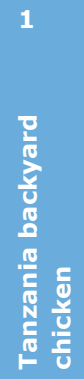 & 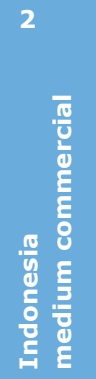 & 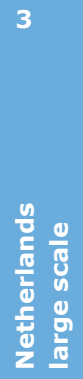 & 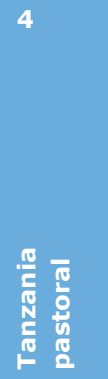 & 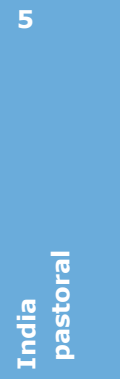 & 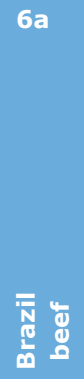 & 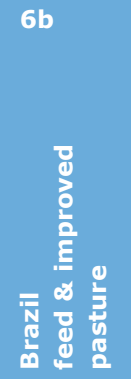 & 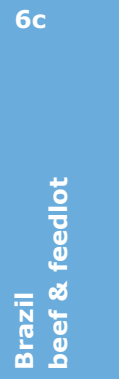 & 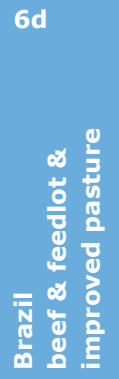 & 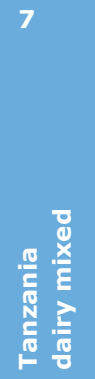 & 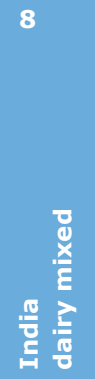 & 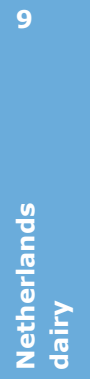 & 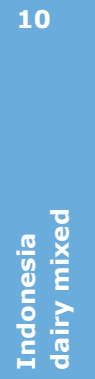 \\
\hline FCR protein $(\mathrm{kg} / \mathrm{kg})$ & & & & 1180 & 1620 & 400 & 375 & 350 & 350 & 400 & 200 & 20 & 50 \\
\hline dressing fraction & & & & 0.47 & 0.55 & 0.55 & 0.55 & 0.55 & 0.55 & 0.47 & 0.55 & 0.5 & 0.55 \\
\hline Bone Free meat $(-)$ & & & & 0.75 & 0.75 & 0.75 & 0.75 & 0.75 & 0.75 & 0.75 & 0.75 & 0.75 & 0.75 \\
\hline $\begin{array}{l}\text { protein in bone free meat } \\
(-)\end{array}$ & & & & 0.18 & 0.18 & 0.18 & 0.18 & 0.18 & 0.18 & 0.18 & 0.18 & 0.18 & 0.18 \\
\hline $\begin{array}{l}\text { FCR on carcass weight } \\
(\mathrm{kg} / \mathrm{kg})\end{array}$ & & & & 159.3 & 218.7 & 54 & 50.625 & 47.25 & 47.25 & 54 & 27 & 2.7 & 6.75 \\
\hline $\begin{array}{l}\text { FRC on Live Weight } \\
(\mathrm{kg} / \mathrm{kg})\end{array}$ & & & & 74.871 & 120.285 & 29.7 & 27.84375 & 25.9875 & 25.9875 & 25.38 & 14.85 & 1.35 & 3.7125 \\
\hline \multicolumn{14}{|l|}{ Dairy } \\
\hline FCR protein $(\mathrm{kg} / \mathrm{kg})$ & & & & & & & & & & 400 & 200 & 20 & 50 \\
\hline $\begin{array}{l}\text { protein content milk } \\
(\mathrm{g} / \mathrm{kg})\end{array}$ & & & & & & & & & & 0.033 & 0.033 & 0.033 & 0.033 \\
\hline FCR milk $(\mathrm{kg} / \mathrm{kg})$ & & & & & & & & & & 13.2 & 6.6 & 0.66 & 1.65 \\
\hline
\end{tabular}




\section{Table A.4 GHG emissions/snapshot}

\begin{tabular}{|c|c|c|c|c|c|c|c|c|c|c|c|c|c|}
\hline Snapshot & 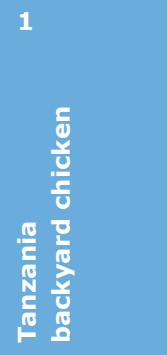 & 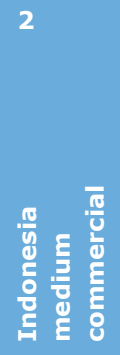 & 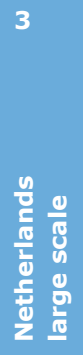 & 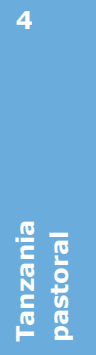 & 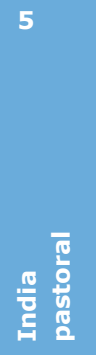 & 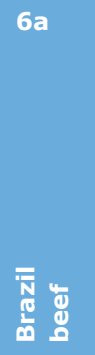 & 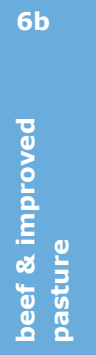 & 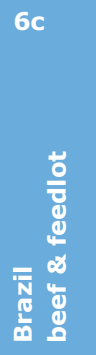 & 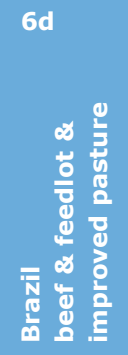 & 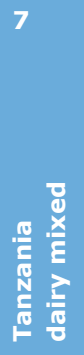 & 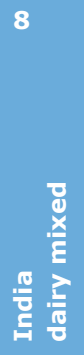 & 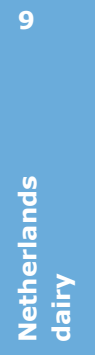 & 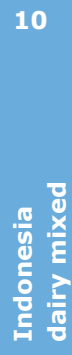 \\
\hline $\mathrm{kg} \mathrm{CO} 2 \mathrm{e} / \mathrm{kg}$ carcass & 4.75 & 5.20 & 5.20 & 38.41 & 46.00 & 46.00 & 42.78 & 40.59 & 36.79 & & & & \\
\hline $\mathrm{kg} \mathrm{CO}_{2} / \mathrm{kg}$ milk & & & & & & & & & & 3.30 & 4.70 & 1.40 & 3.50 \\
\hline $\mathrm{kg} \mathrm{CO} / 2 / \mathrm{kg} \mathrm{egg}$ & 3.05 & & & & & & & & & & & & \\
\hline $\begin{array}{l}\text { Organic and } \\
\text { synthetic fertilizer } \\
\text { use } \mathrm{N}_{2} \mathrm{O}\end{array}$ & $0.32 / / 0.34$ & 0.31 & 0.31 & 0.42 & 0.38 & 0.38 & 0.38 & 0.33 & 0.33 & 0.21 & 0.25 & 0.26 & 0.29 \\
\hline $\begin{array}{l}\text { Fossil fuel use } \\
\text { - transport and } \\
\text { fertilizer production }\end{array}$ & 0.00 & 0.35 & 0.35 & 0.00 & 0.09 & 0.09 & 0.09 & 0.10 & 0.10 & 0.11 & 0.11 & 0.15 & 0.10 \\
\hline $\begin{array}{l}\text { Manufacturing of } \\
\text { fuel/electricity }\end{array}$ & 0.00 & 0.00 & 0.00 & 0.01 & 0.01 & 0.01 & 0.01 & 0.01 & 0.01 & 0.01 & 0.02 & 0.04 & 0.02 \\
\hline Enteric fermentation & 0.00 & 0.00 & 0.00 & 0.53 & 0.49 & 0.49 & 0.49 & 0.51 & 0.51 & 0.55 & 0.52 & 0.44 & 0.49 \\
\hline $\begin{array}{l}\text { Organic waste/ } \\
\text { manure - storage } \\
\mathrm{CH}_{4}\end{array}$ & $0.03 / / 0.03$ & 0.00 & 0.00 & 0.02 & 0.01 & 0.01 & 0.01 & 0.01 & 0.01 & 0.03 & 0.03 & 0.05 & 0.03 \\
\hline $\begin{array}{l}\text { Organic waste/ } \\
\text { manure - storage } \\
\text { N2O }\end{array}$ & $0.59 / / 0.56$ & 0.04 & 0.04 & 0.02 & 0.02 & 0.02 & 0.02 & 0.04 & 0.04 & 0.08 & 0.07 & 0.04 & 0.07 \\
\hline $\begin{array}{l}\text { Land use change } \\
\text { total }\end{array}$ & 0.00 & 0.23 & 0.23 & 0.00 & 0.00 & 0.00 & 0.00 & 0.01 & 0.01 & 0.01 & 0.00 & 0.02 & 0.00 \\
\hline Other & $0.06 / / 0.07$ & 0.08 & 0.08 & 0.00 & 0.00 & 0.00 & 0.00 & 0.00 & 0.00 & 0.00 & 0.00 & 0.00 & 0.00 \\
\hline
\end{tabular}




\section{Table A.5 Nutrient inputs and surpluses}

\begin{tabular}{|c|c|c|c|c|c|c|c|c|c|c|c|c|c|}
\hline Snapshot & 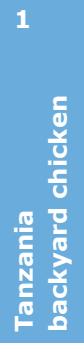 & 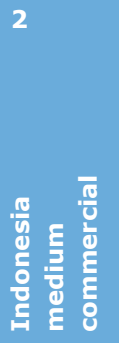 & 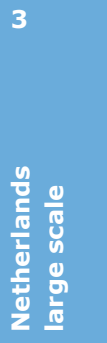 & 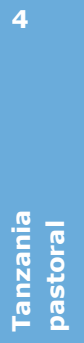 & 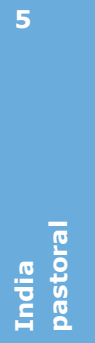 & 产 & 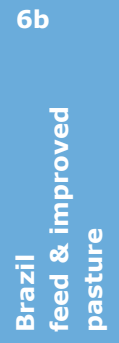 & 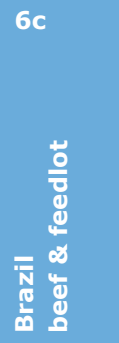 & 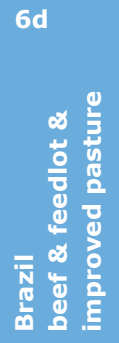 & 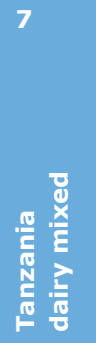 & 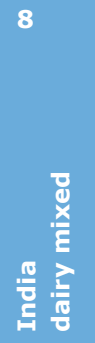 & 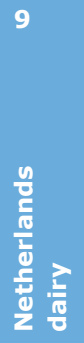 & 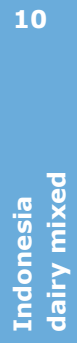 \\
\hline $\begin{array}{l}\mathrm{N} \text { input/ha } \\
\text { (feed and fertilizers) }\end{array}$ & 13 & 2903 & 48638 & 0.2 & 0.1 & 0 & 0 & 8 to 10 & 9 to 10 & 161 & 238 & 258 & 112 \\
\hline $\begin{array}{l}\text { P input/ha } \\
\text { (feed and fertilizers) }\end{array}$ & 2 & 365 & 7164 & 0 & 0 & 0 & 0 & 1 to 8 & 1 to 8 & 17 & 33 & 12 & 12 \\
\hline N suprlus/ha & 12 & 2298 & 29728 & -0.1 & -0.4 & -1 & -1 & 7 to 8 & 7 to 8 & 136 & 221 & 163 & 88 \\
\hline P surplus/ha & 1 & 187 & 1841 & -0.1 & -0.1 & -1 & 0 & 0 to 7 & 0 to 8 & 11 & 29 & -8 & 6 \\
\hline $\begin{array}{l}\mathrm{NH}_{3} \text { emissions } \\
\text { per ha }\end{array}$ & - & - & - & 5 & 6 & 14 & 14 & 15 & 17 & 194 & 75 & 79 & 28 \\
\hline
\end{tabular}




\section{B Annex: Comparison of bottom-up and top-down methodologies and results}

\section{B1 Introduction}

This annex presents a comparison of the top-down and bottom-up approaches used within this study to assess natural capital externalities and dependencies of the livestock sector.

Section B2 highlights key differences between the two approaches, section B3 looks at the specific results for comparable impacts, section B4 contains a set of tables with more details about the comparability of the respective methodologies.

\section{B2 General comparison}

The two analyses have different goals, as the top-down analyses aims at assessing the impacts of livestock sectors worldwide, while the bottom-up analysis looks at selected farming systems in their national context. Both approaches provide a different and useful perspective to inform decision-making. The analyses also differ in the quantification and valuation steps, in factors such as the system boundaries, granularity of data sources and functional unit.

An overview of key differences in natural capital aspects included, system boundaries, valuation methodology, and main limitations of the valuation is given in the following table.

\section{Table A Key differences of top-down and bottom-up assessment}

\begin{tabular}{|c|c|c|}
\hline & Top-down & Bottom-up \\
\hline Goal & $\begin{array}{l}\text { - Assess the environmental } \\
\text { externalities in the livestock sector } \\
\text { worldwide. } \\
\text { - Identify the most material } \\
\text { environmental impacts and } \\
\text { geographical hotspots worldwide. } \\
\text { - Determine the contribution of farming } \\
\text { operations versus their upstream } \\
\text { supply chain. }\end{array}$ & $\begin{array}{l}\text { - Study a representative set of } \\
\text { livestock systems around the world in } \\
\text { terms of environmental impacts. } \\
\text { - Understand differences due to } \\
\text { geographies, levels of intensification, } \\
\text { input use and efficiency. }\end{array}$ \\
\hline
\end{tabular}




\begin{tabular}{|c|c|c|}
\hline & Top-down & Bottom-up \\
\hline Natural capital aspects valued & $\begin{array}{l}\text { - GHG emissions } \\
\text { - Water pollutants } \\
\text { - Air pollutants } \\
\text { - Soil pollutants } \\
\text { - Water consumption } \\
\text { - Land use change }\end{array}$ & $\begin{array}{l}\text { - GHG emissions } \\
\text { - Water pollutants } \\
\text { - Dependency on blue water } \\
\text { - (Non-monetary: Land use and } \\
\text { biodiversity change) }\end{array}$ \\
\hline System boundaries & $\begin{array}{l}\text { - Livestock farming and production of } \\
\text { inputs (upstream supply chain). } \\
\text { - For soil and water pollutants: supply } \\
\text { chain only. }\end{array}$ & $\begin{array}{l}\text { - Livestock farming and production of } \\
\text { feed. } \\
\text { - For water pollutants: on farm only } \\
\text { - For GHG: also other inputs, post farm } \\
\text { transport and processing }\end{array}$ \\
\hline Natural capital valuation methodology & $\begin{array}{l}\text { - The framework is based on an } \\
\text { integrated biophysical and economic } \\
\text { model, and follows an approach } \\
\text { proposed by Keeler et al. (2012). The } \\
\text { valuations are mapped to specific } \\
\text { beneficiaries and show the effects on } \\
\text { specific endpoints. }\end{array}$ & $\begin{array}{l}\text { - GHG externalities: Social Cost of } \\
\text { Carbon } \\
\text { - Eutrophication externality: budget } \\
\text { constraint approach } \\
\text { - Blue water dependency: imputation } \\
\text { method (FAO, 2004) adjusted with } \\
\text { the residual rent method (Thompson } \\
\text { \& Johnson, 2012) }\end{array}$ \\
\hline Main limitations & $\begin{array}{l}\text { No distinction between farming } \\
\text { systems, use of country and/or } \\
\text { global averages for quantification and } \\
\text { valuation of impacts. }\end{array}$ & $\begin{array}{l}\text { Limited coverage of impacts and } \\
\text { farming systems, system boundaries } \\
\text { differ between impacts. }\end{array}$ \\
\hline
\end{tabular}

For GHG and water pollution the same valuation framework is used. However, seen the differences in goal and scope of the two assessments, the methods applied and the data used for the quantification of inputs and impacts differ. These differences are expected to drive variation in the results.

- Functional unit: while the top-down provides intensities at a product level, the bottom-up approach provides intensities at a production system/farm level. For example, dairy farms produce both meat and milk. The top-down assessment allocates the impacts of milk production through an economic allocation method, while the bottom-up analysis looks at the impact per average protein produced. A similar difference in the object of the assessment, and thus in the functional unit, applies to poultry.

- System boundaries: The top-down assessment includes emissions to water upstream in the supply chain only (such as emissions due to fertilizer use for feed production), while the bottom-up assessment looks at nutrients from manure and fertilizer on the livestock farm only. For GHG emissions, wider downstream system boundaries are considered in the bottom-up, as those include transportation and processing.

- Farm inputs data: Input requirements of a farm are livestock system specific in the bottom-up analysis, while global average factors based on U.S. input related data is used for the top-down analysis for all countries;

- Granularity of data sources: Impacts on natural capital caused by farms are production system specific in the bottom-up analysis for animal husbandry and feed production. In the top-down approach, natural capital impacts occurring in the farm are quantified at a country level whenever is possible. In all other cases and for impacts occurring in the supply chain global average factors are used.

More details about how the bottom-up and top-down approaches differ can be found in the tables in section B4.

\section{B3 Results compared}

This section compares the results of the bottom-up valuation of GHG emissions of selected livestock production snapshots with the results of the top-down analysis for these countries. Furthermore, water pollution and land use are also valued both top-down and bottom-up, but with important methodological differences. For these impacts an overview of differences in the results is also given. 
It is evident that the two approaches use different parameter values describing the considered livestock systems and while some of them may lead to having higher impacts on the top-down, other may lead to having higher impacts on the bottom-up. Thus, there is relatively wide range of variability on the results obtained for each of the countries selected for the snapshots.

In general, because of the highest granularity of modelling and data sources, a bottom-up approach is recommended. However, because in practice local data and models are not always available, a top-down approach is a useful tool as it incorporates high level averages, allowing the calculation of estimates when there are data gaps and the coverage of a broad scope.

This section compares the results of the bottom-up valuation of GHG emissions and water pollutants for one snapshot for each sector, poultry, beef and dairy. The snapshots chosen are considered to be representative of the whole country and are found to be major contributors to the natural capital cost in the top-down analysis. Although the Netherlands was not found to be a major contributor worldwide for poultry, this snapshot represents the typical industrial poultry system, and the country was included in the comparison in order to give an indication of how results for poultry compare for the top-down and bottom-up.

- Snapshot 3: The Netherlands industrial broilers.

- Snapshot 6: Brazil beef grazing with feedlot. This system does not strictly represent the average in the country but its environmental profile is highly comparable to the most common system of pure grazing

- Snapshot 8: India dairy mixed feeding

\section{GHG emissions}

\section{Table B Comparison of GHG emissions}

\begin{tabular}{|c|c|c|}
\hline Poultry & Top-down (\$/kg protein) & Bottom-up (\$/kg protein) \\
\hline Object of the assessment & Poultry meat & Poultry systems (meat) \\
\hline Snapshot 3- The Netherlands & 5.84 & 4.67 \\
\hline Beef & Top-down ( $\$ / \mathbf{k g}$ protein) & Bottom-up ( $\$ / \mathbf{k g}$ protein) \\
\hline Object of the assessment & Beef meat & Pure beef systems \\
\hline Snapshot 6- Brazil & 35.34 & 36.46 \\
\hline Dairy & Top-down (\$/kg protein) & Bottom-up ( \$/kg protein) \\
\hline Object of the assessment & Dairy milk & Dairy systems (meat and milk) \\
\hline Snapshot 8- India & 6.95 & 18.23 \\
\hline
\end{tabular}

Results for GHG emissions are in the same order of magnitude for the top-down and bottom-up. Even if the valuation coefficient used is the same (social cost of carbon), the process undertaken for the quantification of impacts differs. Disparities for the results for India can be connected to the factors mentioned in section B2 of this annex. Furthermore, the following differences in method and data sources specific to GHG give additional insight into the origin of the variation between the results of top-down and bottom-up.

- When looking at the scope of the analysis, the bottom-up considers also post farm gate transport and processing while the top-down does not.

- Regarding data granularity, the bottom-up uses a herd model, farming system type and climatic zone to determine GHG emissions. In the case of the top-down, country specific factors are used for to determine direct GHG emissions from livestock such as enteric fermentation, while global average factors are used to quantify indirect GHG emissions such as feed production.

- Regarding data sources, in the case of the top-down approach, sources include FAOSTAT data for GHG emissions from enteric fermentation, and life cycle assessment studies to quantify GHG emissions from energy use. In the case of the bottom-up, GHG emissions are quantified based on the Global 
Livestock Environmental Assessment Model (GLEAM) by FAO and the agronomic models of the livestock snapshots developed for the purposes of the this study.

The two studies use the same monetary coefficient for climate change, a social cost of carbon of US $\$ 128 / \mathrm{t} \mathrm{CO}_{2}$ eq. With scope differences in mind, results from the bottom-up valuation are expected to be more representative of the country's livestock sector actual emissions, as they are based on modelling of livestock farms using region specific data.

\section{Water pollution}

Water pollution is assessed with regards to emissions of Nitrogen and Phosphorous into water sources through leaching, which can contribute to eutrophication.

The two assessments look at different parts of the supply chain, making the results hardly comparable. The top-down analysis quantifies impacts for the upstream supply chain (inputs to the farm) using global average obtained from an environmentally extended input output model (which compiles many data sources such as life cycle assessment studies), the bottom-up analysis models emissions taking place on farm, both from manure and feed production, using a nutrient balance.

The two analysis do not use the same valuation approach. The top-down analysis uses monetary coefficients on average of $11,5 \$ / \mathrm{kg}$ pollutant, while the bottom-up analysis uses coefficients with an average value of $2,5 \$ / \mathrm{kg}$ pollutant. Both analysis use global averages. For more information see section B2 of this annex.

\section{Table C Comparison of water pollution}

\begin{tabular}{|c|c|c|}
\hline Poultry & Top-down ( $\$ / \mathbf{k g}$ protein) & Bottom-up ( $\$ / \mathbf{k g}$ protein) \\
\hline Object of the assessment & Poultry meat & Poultry systems (meat) \\
\hline Snapshot 3- The Netherlands & 0.39 & 0 \\
\hline Beef & Top-down ( $\$ / \mathbf{k g}$ protein) & Bottom-up ( $\$ / \mathbf{k g}$ protein) \\
\hline Object of the assessment & Beef meat & Pure beef systems \\
\hline Snapshot 6- Brazil & 0.37 & 1.84 \\
\hline Dairy & Top-down ( $\$ / \mathbf{k g}$ protein) & Bottom-up ( $\$ / \mathbf{k g}$ protein) \\
\hline Object of the assessment & Dairy milk & Dairy systems (meat and milk) \\
\hline Snapshot 8- India & 0.23 & 0.23 \\
\hline
\end{tabular}

In the bottom-up analysis poultry is considered to have no water pollution impact because no emissions are considered to happen on farm. Manure is applied as fertilizer by other farms and resulting emissions are entirely attributed to other farms. Looking at beef systems, supply chain externalities quantified top-down are found to be much smaller than those on farm, with water pollution external costs in the range of $0.23-0.37$ as opposed to US\$1.84 to $4.25 / \mathrm{kg}$ protein. For beef, the main difference in scope is that the bottom-up approach considers water pollution from manure as well as from feed production on farm, while the top-down approach only captures water pollution impacts from feed produced as part of the supply chain, excluding water pollution from feed produced on farm and from manure. Valuation coefficients used in those approaches also vary due to methodological reasons (see section 2.3.1 for the top-down approach and 2.4.1 for the bottom-up approach).

\section{Land use}

Valuation of natural capital externalities is performed in both the top-down and the bottom-up assessments but the underlying objective, data sources, level of granularity and valuation frameworks differ (see table M). 
Table D Comparison of land value in Maasai steppe with Tanzania land use coefficient in the top-down approach in $\$ /$ ha

\begin{tabular}{lll} 
& Top-down & Bottom-up \\
\hline Object of the assessment & Land use valuation coefficients & $\begin{array}{l}\text { Ecosystem benefits used to estimate } \\
\text { natural capital assets }\end{array}$ \\
\hline Geographical scope & Tanzania & Maasai steppe (Tanzania) \\
\hline Value & $1,726 \$ / \mathrm{ha} / \mathrm{yr}$ & $\begin{array}{l}\text { - Average annual value of ecosystem } \\
\text { benefits } 30 \$ / \text { ha } / \mathrm{yr}\end{array}$ \\
& & \begin{tabular}{l} 
Carbon stocks $82 \$ / \mathrm{ha}$ \\
\hline
\end{tabular} \\
\hline
\end{tabular}

Values per hectare obtained by the top-down approach are 60 times higher than from bottom-up. The two values are again hardly comparable, as they have a different significance. One is developed as part of a global assessment of the value of ecosystems, the other for a sub-national model of land conversion. Because of this the two studies use the value per hectare in different ways (top-down as a monetary coefficient of opportunity cost of ecosystems for land use, bottom-up as an input to a dynamic model of natural capital asset value).

The following considerations give some additional background on the differences in the methodologies.

- Regional scope. The top-down estimates the average value of natural ecosystems for Tanzania, while the bottom-up focuses on a sub-region, the Maasai steppe, and includes natural as well as agricultural ecosystems. In this region the climate is especially arid which can lead to low average supply of ecosystem services.

- Ecosystem services scope. A wider range of biomes and ecosystem services are considered as part of the top-down analysis: cultural, provisioning and regulating services are included, as opposed to a more specific set in the bottom-up.

- In the top-down approach, regulating services contribute to an average of $46 \%$ of the total value of land use. Moderation of extreme events, regulation of water flows, waste treatment and erosion prevention are examples of valuable ecosystem services estimated.

- The bottom-up assessment focuses on those ecosystem services with local benefits for which evidence is available concerning their relevance in the Maasai region and reliable data can be found. Two key services were considered material but could not be quantified due to lack of data, water cycle regulation and carbon sequestration. Furthermore the bottom-up framework leaves out regulating ecosystem services that can lead to double counting by estimating intermediate benefits through related final benefits. For example ecosystem services that underlie farm yields such as nutrient cycling, pollination or erosion prevention are estimated as a share of the value of crops and livestock.

- Data specificity. The top-down method aggregates values per biome from different countries from the TEEB database, which can be based on only a few observations with a high uncertainty range (up to three orders of magnitude). The bottom-up approach uses local surveys and valuations. It only takes values based on the local ecosystems and economy and therefore has a lower uncertainty.

- Valuation method. The top-down valuation uses values estimated with a mix of market and non-market valuation methods while the bottom-up framework is based only on market prices of ecosystem benefits or substitute products. 


\section{B4 Comparative tables for the top-down and bottom-up approaches}

\section{Table E Environmental externalities included in valuation scope}

\begin{tabular}{|c|c|c|}
\hline \multicolumn{3}{|l|}{ In scope of valuation } \\
\hline \multicolumn{3}{|c|}{ Partially in scope of valuation } \\
\hline \multicolumn{3}{|c|}{ Quantified but not montized } \\
\hline & Top-down approach & Bottom-up approach \\
\hline GHG emissions & $x$ & $x$ \\
\hline Air pollutants & $x$ & \\
\hline Water pollutants & x (fertilizers) & $\mathrm{x}$ (fertilizers and manure) \\
\hline Soil pollutants & x (pesticides) & \\
\hline Water consumption & $x$ & \\
\hline \multicolumn{2}{|l|}{ Land occupation } & $x$ (not monetized) \\
\hline \multicolumn{2}{|l|}{ Biodiversity change } & $x$ (not monetized) \\
\hline Land use change & $x$ & x (Land valuation Tanzania, see table M) \\
\hline
\end{tabular}

\section{Table F Environmental dependencies included in valuation scope}

\begin{tabular}{ll} 
& Bottom-up approach \\
\hline Blue water & $\times$ \\
\hline Natural capital (aggregated) & x(Land valuation Tanzania) \\
\hline
\end{tabular}

\section{Table G Processes included in system boundaries}

\begin{tabular}{|c|c|c|}
\hline & Top-down approach & Bottom-up approach \\
\hline Production of feed and other inputs & $x$ & $\begin{array}{l}\text { x (GHG, Land use: feed, Water } \\
\text { pollution: on-farm feed production) }\end{array}$ \\
\hline Livestock keeping & $\begin{array}{l}\text { X (GHG, air pollutants, water } \\
\text { consumption, land use change) }\end{array}$ & $x$ \\
\hline \multicolumn{2}{|l|}{ Processing, packaging after farm gate } & x (GHG) \\
\hline
\end{tabular}

\section{Table $\mathrm{H} \quad$ Multifunctional processes and allocation}

\begin{tabular}{lll} 
Multifunctional processes & Top-down approach & Bottom-up approach \\
\hline Production of feed and other inputs & N/A & $\begin{array}{l}\text { Crops and crop residues: digestibility/ } \\
\text { economic allocation (1) }\end{array}$ \\
\hline Livestock production & $\begin{array}{l}\text { Economic allocation as Environmentally } \\
\text { Extended Input Output model is used }\end{array}$ & $\begin{array}{l}\text { Animal products: allocation by protein } \\
\text { content. }\end{array}$
\end{tabular}

(1) Digestibility is used to allocate land use between crops and crop residues, as economic value of crop residues is very location specific and not always known. Economic allocation is used for agro-industry byproducts. For blue water use, all impacts are allocated to the main crop, following the common water footprinting approach. 


\section{Table I Level of detail of input data}

\begin{tabular}{lll} 
Livestock farming system specific data & $\begin{array}{l}\text { Top-down approach } \\
\text { No differentiation between farming } \\
\text { systems. }\end{array}$ & $\begin{array}{l}\text { Bottom-up approach } \\
\text { Feed amount and composition. } \\
\text { Environmental drivers (on farm/ } \\
\text { feedlot) }\end{array}$ \\
\hline Country specific data & $\begin{array}{l}\text { Quantification and valuation of } \\
\text { operational impacts (excl. GHG). }\end{array}$ & $\bullet$ Valuation of blue water dependency. \\
& $\begin{array}{l}\text { Total volumes of livestock } \\
\text { commodities produced per country. }\end{array}$ & production) \\
\hline Global data & $\begin{array}{l}\text { Quantification and valuation of supply } \\
\text { chain impacts (i.e. feed production). }\end{array}$ & $\bullet$ Valuation of impacts leaching factors \\
& Valuation of GHG.
\end{tabular}

\section{Table J Valuation approaches overview}

$\begin{array}{lc} & \text { Top-down approach } \\ \text { GHG emissions } & \text { Social Cost of Carbon } \\ & \text { (U.S. Government) }\end{array}$

Air pollutants Based on impacts on human health (willingness to pay) and ecosystems (diverse approaches that value the contribution of biodiversity to the delivery of provisioning, regulating and cultural services).

Eutrophication

Based on impacts on human health (willingness to pay and restoration costs) and ecosystems (hedonic pricing).

Soil pollutants Based on impacts on human health and ecosystems (see Air pollutants for detail).

Water consumption

Valuation of water consumption based on impacts on human health and ecosystems (see Air pollutants for detail).

Water dependency

Land use change
Valuation methodology for land use change based on the ecosystem services lost from the conversion of natural ecosystems to agricultural land. Ecosystem services included are: provisioning, regulating and cultural services.
Based on impact on biodiversity and human well-being (budget constraint approach)
Valuation of water dependency based on contribution of irrigation to crops' value.

Natural capital valuation at regional level (Maasai steppe in Tanzania) based on land cover change scenarios and a set of provisioning, regulating and cultural ecosystem goods and services.

Carbon stock loss valuation at regional level (Maasai steppe in Tanzania) based on land cover change scenarios and Social Cost of Carbon 


\section{Table K Value transfer details Top-down Natural capital valuation}

\begin{tabular}{|c|c|c|c|}
\hline \multirow[t]{2}{*}{ Environmental externality } & \multirow[t]{2}{*}{ Impact on... } & \multicolumn{2}{|l|}{ TOP-DOWN APPROACH* } \\
\hline & & Change in valued attribute & Value transfer \\
\hline \multirow[t]{3}{*}{ Land use change } & Provisioning services & \multirow{3}{*}{$\begin{array}{l}\text { Hectares of natural } \\
\text { ecosystems replaced with } \\
\text { alternative land uses }\end{array}$} & \multirow{3}{*}{$\begin{array}{l}\text { Country-specific ecosystem } \\
\text { distribution. }\end{array}$} \\
\hline & Cultural services & & \\
\hline & Regulating services & & \\
\hline $\begin{array}{l}\text { Air pollutants, Soil pollutants, } \\
\text { Water consumption }\end{array}$ & Habitat \& biodiversity & $\begin{array}{l}\text { Change in the potentially } \\
\text { affected fraction of species }\end{array}$ & $\begin{array}{l}\text { Geophysical and social } \\
\text { conditions, Species density, } \\
\text { Average Ecosystem value }\end{array}$ \\
\hline Water pollutants & & Change in secchi depth & $\begin{array}{l}\text { Average freshwater bodies } \\
\text { volume and perimeter, } \\
\text { population density }\end{array}$ \\
\hline Air pollutants, Soil pollutants & Human health & $\begin{array}{l}\text { Change in disability-adjusted } \\
\text { life year }\end{array}$ & Income elasticity \\
\hline Water consumption & & $\begin{array}{l}\text { Change in disability-adjusted } \\
\text { life year }\end{array}$ & $\begin{array}{l}\text { Proportion of population } \\
\text { vulnerable to malnutrition } \\
\text { and income elasticity. }\end{array}$ \\
\hline Water pollutants & & $\begin{array}{l}\text { Change in disability-adjusted } \\
\text { life year }\end{array}$ & $\begin{array}{l}\text { Average freshwater bodies } \\
\text { volume and perimeter, } \\
\text { population density, } \\
\text { population structure, } \\
\text { population with access to } \\
\text { safe drinking water, income } \\
\text { elasticity }\end{array}$ \\
\hline Water pollutants & & $\begin{array}{l}\text { Change in water treatment } \\
\text { costs }\end{array}$ & $\begin{array}{l}\text { Average freshwater bodies } \\
\text { volume and perimeter }\end{array}$ \\
\hline
\end{tabular}

\section{Table L Value transfer details Bottom-up Natural capital valuation - Maasai steppe case study}

\begin{tabular}{ll} 
& $\begin{array}{l}\text { Bottom-up approach } \\
\text { (In-depth case study: Maasai steppe in Tanzania) }\end{array}$ \\
Provisioning services & $\begin{array}{l}\text { Unit transfer for } 12 \text { ecosystem services } \\
\text { Cultural services }\end{array}$ \\
\hline Regulating services & $\begin{array}{l}\text { Region-specific value and land cover } \\
\text { Valued indirectly through final ecosystem services supply } \\
\text { (i.e. soil fertility services valued through crop or livestock }\end{array}$ \\
\hline productivity)
\end{tabular}




\section{Table M Land valuation methodologies}

\begin{tabular}{|c|c|c|}
\hline & Top-down & $\begin{array}{l}\text { Bottom-up in-depth case study: } \\
\text { Maasai steppe in Tanzania }\end{array}$ \\
\hline Valued dimension & Natural capital cost of land use change & $\begin{array}{l}\text { Internal natural capital value of (agro) } \\
\text { ecosystems }\end{array}$ \\
\hline Geographical coverage & Global & Maasai steppe, Tanzania \\
\hline Input data & $\begin{array}{l}\text { Biophysical modelling: Country- } \\
\text { specific ecosystem distribution based on } \\
\text { Olson et al. (2004). } \\
\text { Economic modelling: Global average } \\
\text { for the value of ecosystem services } \\
\text { from de Groot et al. (2012). }\end{array}$ & $\begin{array}{l}\text { Biophysical and economic } \\
\text { modelling: Region-specific data from } \\
\text { valuations of local ecosystem and } \\
\text { agricultural surveys. }\end{array}$ \\
\hline Valued attribute & $\begin{array}{l}\text { Hectares of natural ecosystems replaced } \\
\text { with alternative land uses. }\end{array}$ & $\begin{array}{l}\text { - Supply of individual ecosystem } \\
\text { services by farmland, rangeland and } \\
\text { national parks (time series). } \\
\text { - Regional land cover (time series). }\end{array}$ \\
\hline \multirow[t]{2}{*}{ Valuation approach } & \multirow{2}{*}{$\begin{array}{l}\text { Valuation methodology for land use } \\
\text { change based on the ecosystem } \\
\text { services lost from the conversion of } \\
\text { natural ecosystems to agricultural } \\
\text { land. Ecosystem services included are: } \\
\text { provisioning, regulating and cultural } \\
\text { services. }\end{array}$} & $\begin{array}{l}\text { Natural capital valuation at regional } \\
\text { level (Maasai steppe in Tanzania) based } \\
\text { on land cover change scenarios and } \\
\text { a set of provisioning, regulating and } \\
\text { cultural ecosystem goods and services. }\end{array}$ \\
\hline & & $\begin{array}{l}\text { Carbon stock loss valuation at regional } \\
\text { level (Maasai steppe in Tanzania) based } \\
\text { on land cover change scenarios and } \\
\text { Social Cost of Carbon }\end{array}$ \\
\hline
\end{tabular}




\section{Table N Water valuation methodologies}

\begin{tabular}{|c|c|c|}
\hline & Top-down & Bottom-up \\
\hline Valued dimension & $\begin{array}{l}\text { Natural capital cost of water } \\
\text { consumption }\end{array}$ & $\begin{array}{l}\text { Dependency of agriculture on } \\
\text { natural capital for blue water use }\end{array}$ \\
\hline Geographical coverage & Global & 6 crops in 7 countries (12 combinations) \\
\hline Input data & $\begin{array}{l}\text { Biophysical modelling: } \\
\text { - Country-specific input data following } \\
\text { Pfister et al. (2011) approach, for } \\
\text { example WRI (2013) water scarcity. } \\
\text { - Country-specific ecosystem } \\
\text { distribution based on Olson et al. } \\
\text { (2004). } \\
\text { Economic modelling: } \\
\text { - NEEDS project from Desaigues et al. } \\
\text { (2006). The value used for DALYs is } \\
\text { global due to ethical reasons. } \\
\text { Global average for the value of } \\
\text { ecosystem services from de Groot et } \\
\text { al. (2012). }\end{array}$ & $\begin{array}{l}\text { Biophysical modelling: Crop-specific } \\
\text { country average blue water footprints } \\
\text { (Mekonnen and Hoekstra 2010) and } \\
\text { irrigation response factors. } \\
\text { Economic modelling: Crop-specific } \\
\text { country average cost structure, global } \\
\text { or national crop trading prices. }\end{array}$ \\
\hline \multirow[t]{2}{*}{ Valued attribute } & $\begin{array}{l}\text { Change in DALYs due to malnutrition } \\
\text { and lack of domestic water caused by } \\
\text { decreased water availability }\end{array}$ & $\begin{array}{l}\text { Contribution of irrigation water to } \\
\text { increased crop yields }\end{array}$ \\
\hline & $\begin{array}{l}\text { Change in the potentially affected } \\
\text { fraction of species }\end{array}$ & \\
\hline \multirow[t]{2}{*}{ Valuation approach } & Willingness-to-pay & Market prices \\
\hline & $\begin{array}{l}\text { Multiple - Contribution of biodiversity to } \\
\text { the delivery and value of provisioning, } \\
\text { regulating and cultural services }\end{array}$ & \\
\hline
\end{tabular}




\section{Authors}

W. Baltussen - Wageningen Economic Research

T. Achterbosch - Wageningen Economic Research

E. Arets - Wageningen Environmental Research

A. de Blaeij - Wageningen Economic Research

N. Erlenborn - True Price

V. Fobelets - True Price

P. Galgani - True Price

A. De Groot Ruiz - True Price

R. Hardwicke - Trucost

S.J. Hiemstra - Wageningen Livestock Research

P. van Horne - Wageningen Economic Research

O. A. Karachalios - True Price

G. Kruseman -Wageningen Economic Research

R. Lord - Trucost

W. Ouweltjes - Wageningen Livestock Research

M. Tarin Robles - Trucost

T. Vellinga - Wageningen Livestock Research

L. Verkooijen - True Price

\section{Publication number}

2017-039

ISBN 978-90-8615-734-1

\section{Text editing}

Speer Publication

\section{Design}

Van Betuw Grafisch Ontwerp

\section{Photography}

Cover photo, page 14-15, 26-27, 34-35, 54-55, 122-123 - Pixabay

Page 76-77, 132-133, 142-143 - Dr. Luiz Otavio Campos da Silva

Page 79, 136-137 - Adriaan Vernooij

Page 80 - Peter van Horne

Page 110-111 - Shutterstock

Page 121 herds - Dolapo Faiola / herdsman - Vince Smith

Page 152-153 - Jan van der Lee

\section{Wageningen Economic Research, The Hague, 2017}

Baltussen W., T. Achterbosch, E. Arets, A. de Blaeij, N. Erlenborn, V. Fobelets, P. Galgani, A. De Groot Ruiz, R. Hardwicke, S.J. Hiemstra, P. van Horne, O. A. Karachalios, G. Kruseman, R. Lord, W. Ouweltjes, M. Tarin Robles, T. Vellinga, L. Verkooijen, 2017. Valuation of livestock eco-agri-food systems: poultry, beef and dairy, Wageningen, Wageningen Economic Research, Report 2017-039. 174 pp. 

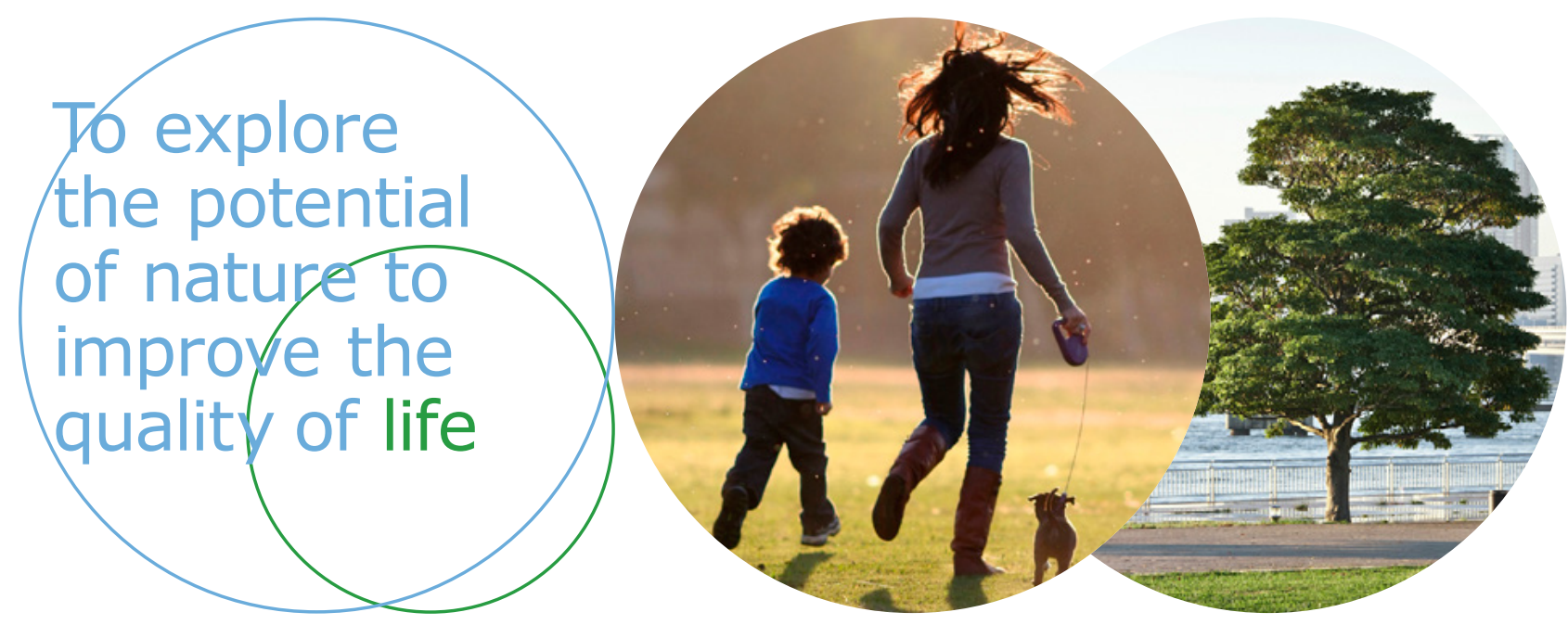

Wageningen Economic Research P.O. Box 29703

2502 LS The Hague

The Netherlands

$\mathrm{T}+31(0) 703358330$

E communications.ssg@wur.n

www.wur.eu/economic-research

REPORT

2017-039

ISBN 978-90-8615-734-1
Wageningen Economic Research is one of the world's leading independent socio-economic research institutes. Wageningen Economic Research's unique data, models and knowledge offer clients insight and integrated advice on policy and decision-making in an innovative manner, and ultimately contribute to a more sustainable world. Wageningen Economic Research is part of Wageningen University and Research.

The mission of Wageningen University and Research is "To explore the potential of nature to improve the quality of life". Under the banner Wageningen University \& Research, Wageningen University and the specialised research institutes of the Wageningen Research Foundation have joined forces in contributing to finding solutions to important questions in the domain of healthy food and living environment. With its roughly 30 branches, 5,000 employees and 10,000 students, Wageningen University \& Research is one of the leading organisations in its domain. The unique Wageningen approach lies in its integrated approach to issues and the collaboration between different disciplines. 